SAND81-1045

Unlimited Release

September 1981

\title{
Strategic Petroleum Reserve (SPR) Geological Site Characterization Report Big Hill Salt Dome
}

R. J. Hart

Terri Smith Ortiz

Thomas R. Magorian-Consultant

Prerared by Sandia National Laboratories,

Albuquerque, NM 87185 and Livermore, CA 94550

for the United States Department of Energy under

Contract DE-AC04-76DP00789.

When printing a copy of any digitized SAND Report, you are required to update the markings to current standards. 


\section{Sandia Laboratories}

date: December 2, 1981

Albuquerque. New Mexico

to: Distribution

from: fothuy
f. F. Nely, 4543

subject: Replacement Pages for Strategic Petroleum Reserve (SPR) Geological site Characterization Report Big Hill Salt Dome, SAND81-1045

The color overlays of Figures 5-1, 5-2, and 6-5 were shifted slightly when printed the first time. Therefore, we have had these figures reprinted and have enclosed them for your use. Please remove the old Figures 5-1, 5-2, and 6-5 and replace them with the new ones.

We are sorry for any inconvenience this may cause you.

TSO : $4543:$ jmu 


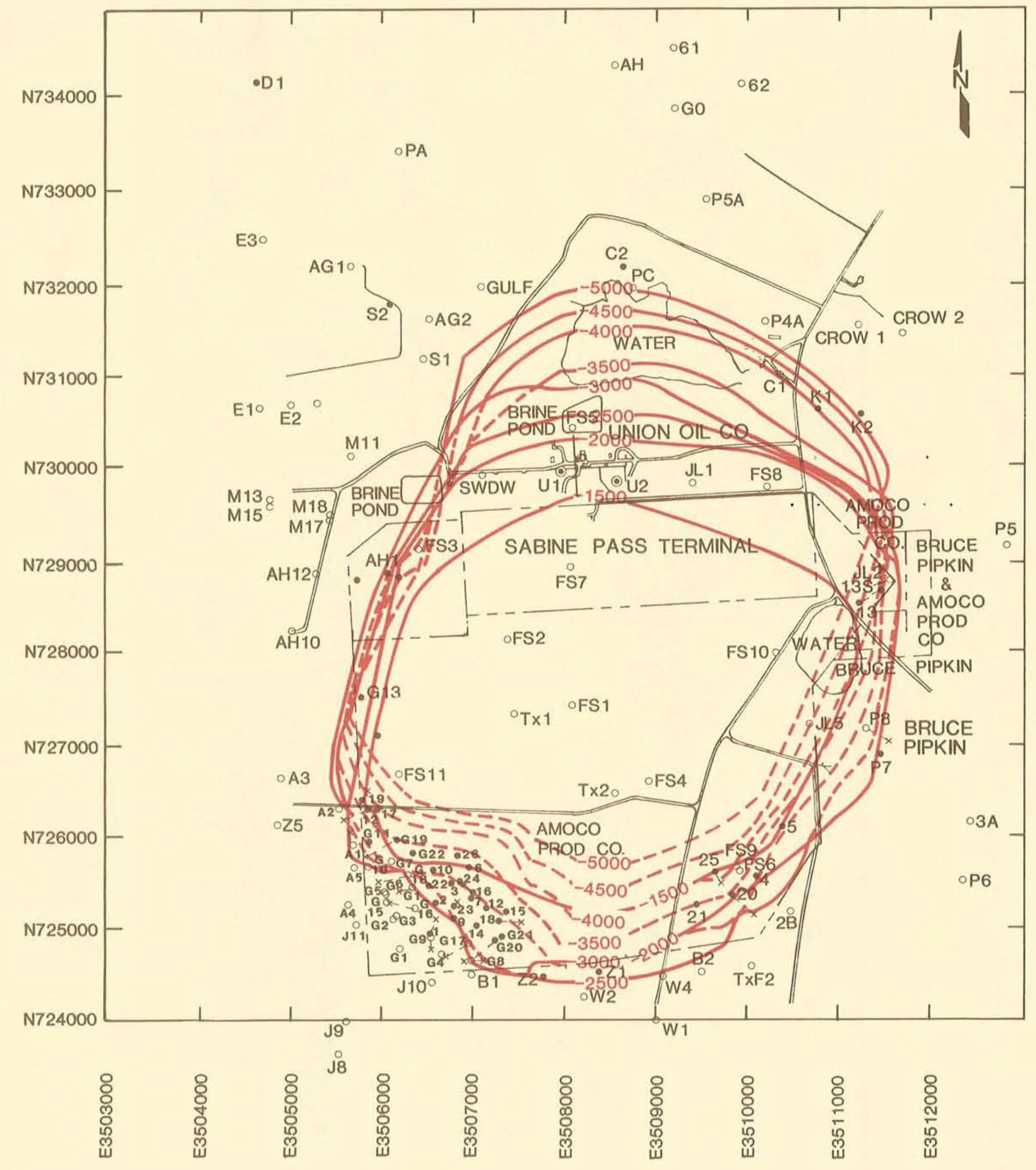

\section{NOTES}

1. SEE APPENDIX B FOR EXPLANATION OF WELL NUMBERS AND

2. CONTOURED DEPTHS MEASURED IN FEET BELOW DRILLING FLOOR. LEGEND

-U1 UNION OIL LPG CAVERN

$+\quad$ SURFACE LOCATION OF WELL.

- G2 BOTTOM HOLE LOCATION OF WELL.

- G2 BOTTOM HOLE LOCATION OF SIDETRACK HOLE.

-G2 DRILLED AS VERTICAL HOLE. NO BOTTOM HOLE LOCATION AVAILABLE. G2 LOCA
SALT.

- SALT DEPTH CONTOURS

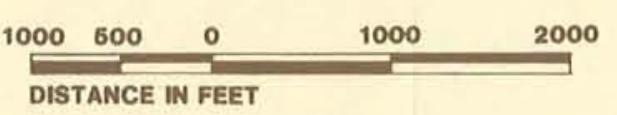

BIG HILL SALT DOME STRUCTURE MAP-SALT

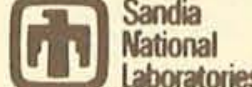




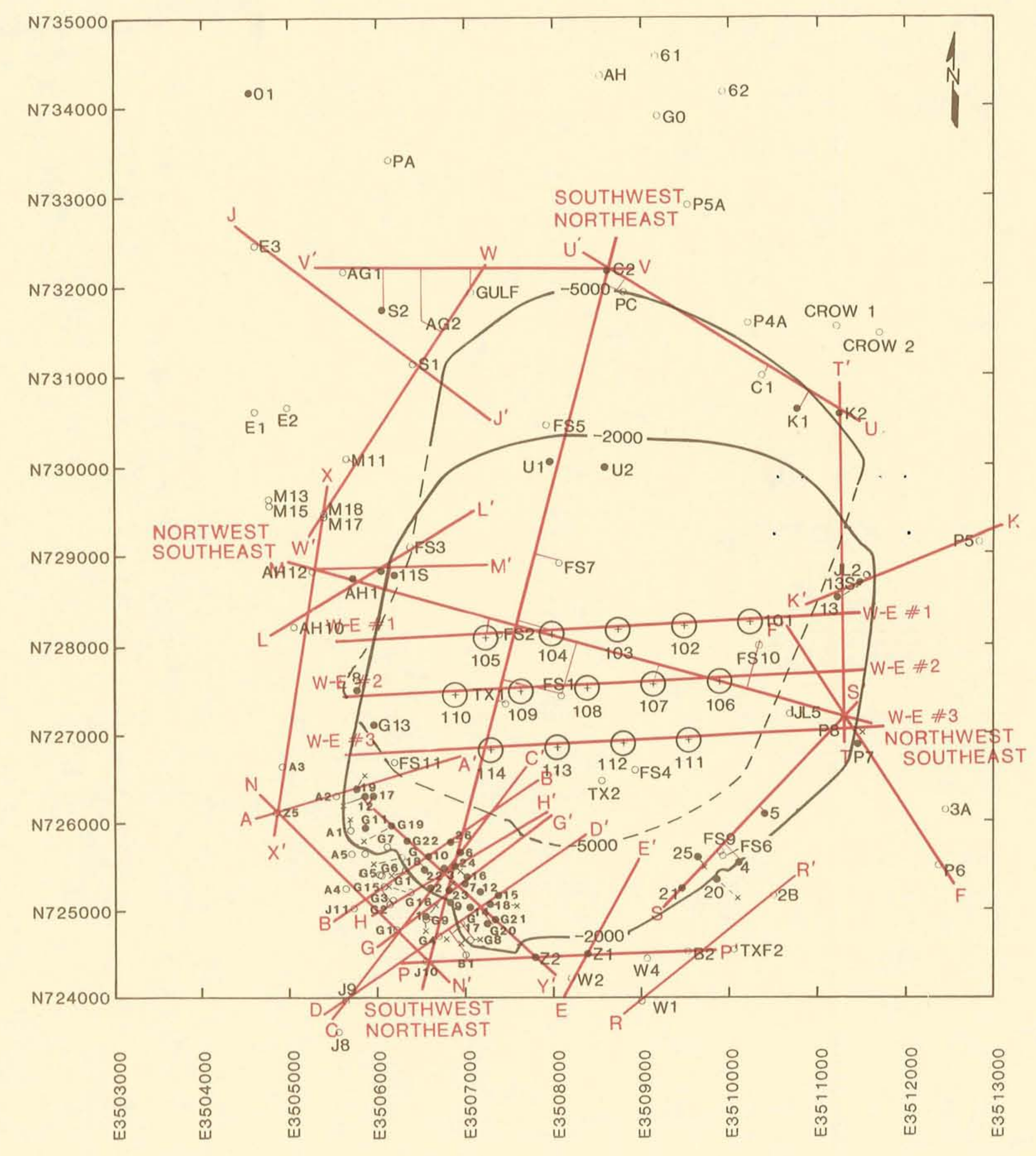

NOTES

1. SEE APPENDIX B FOR EXPLANATION

OF WELL NUMBERS AND WELL LOCATIONS. LEGEND

(.) UI UNION OIL LPG CAVERN

SURFACE LOCATION OF WELL.

BOTTOM HOLE LOCATION OF WELL.

G2 BOTTOM HOLE LOCATION OF

G2 SIDETRACK HOLE

G2 DRILLED AS VERTICAL HOLE. NO BOTTOM
HOLE LOCATION AVAILABLE

( PROPOSED SPR CAVERNS

101 SECTION LINE

WELLS PROJECTED TO SECTION LINE

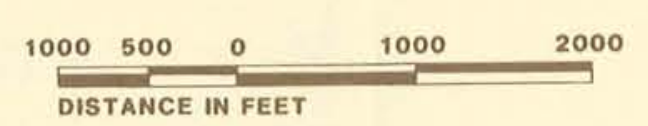

BIG HILL SALT DOME

SECTION REFERENCE MAP

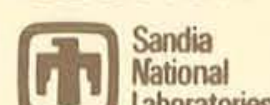




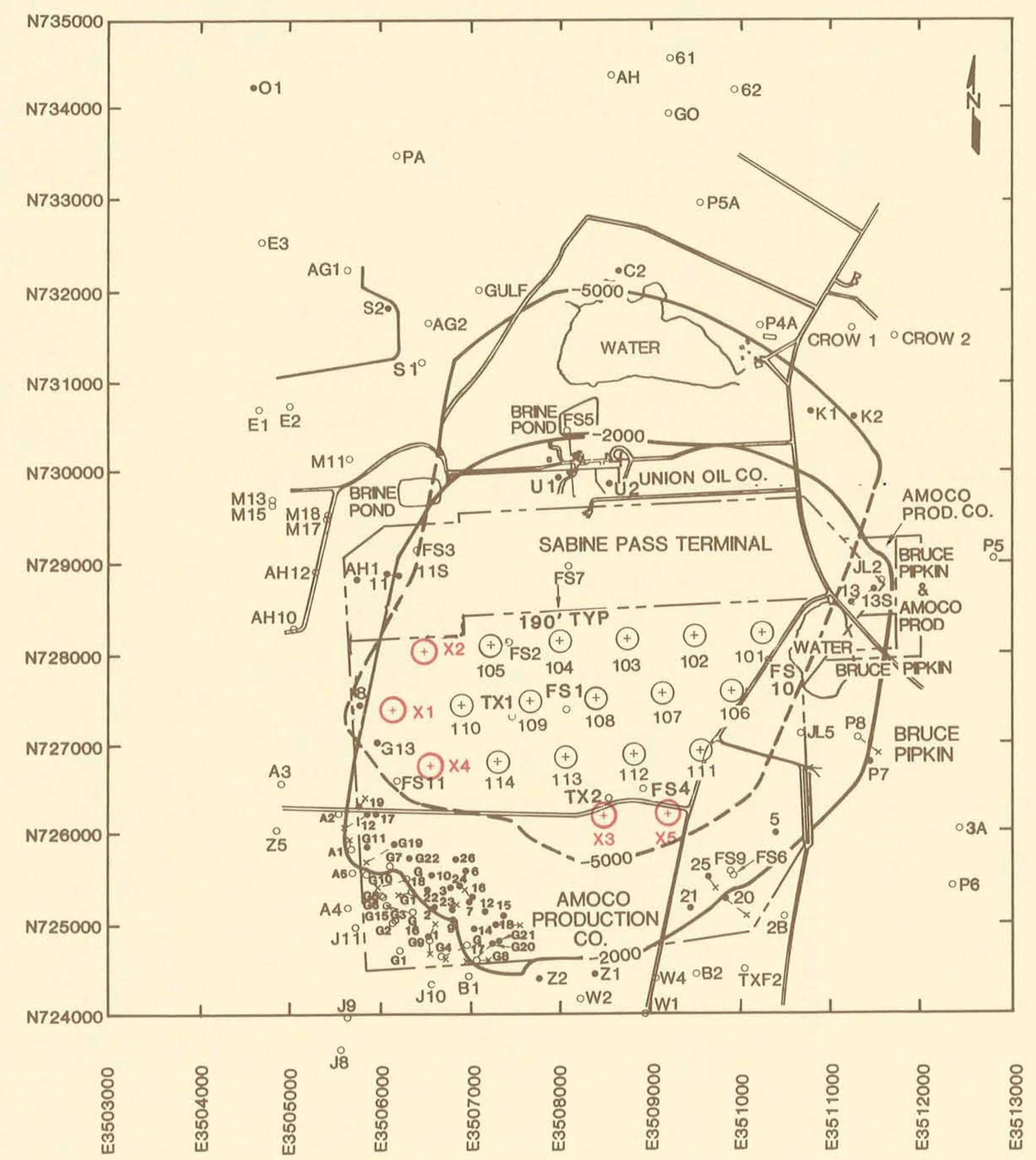

POTENTIAL EXPANSION CAVERN LAYOUT BIG HILL SALT DOME

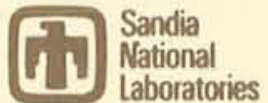




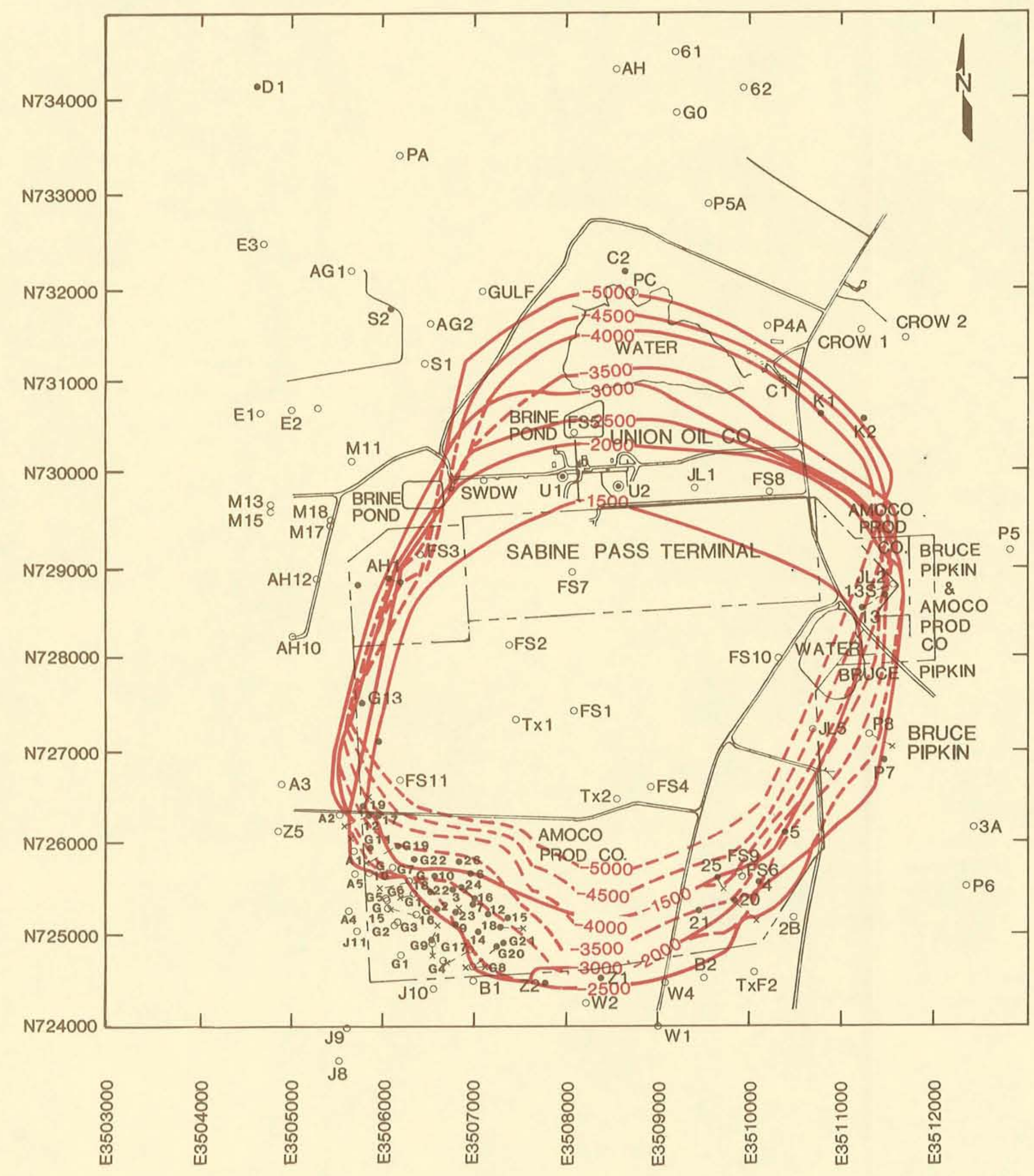

NOTES

1. SEE APPENDIX B FOR EXPLANATION OF WELL NUMBERS AND

2. CONTOURED DEPTHS MEASURED IN FEET BELOW DRILLING FLOOR LEGEND

- U1 UNION OIL LPG CAVERN.

+ SURFACE LOCATION OF WELL.

- g2 BotTOM HOLE LOCATION OF WELL.

G2 BOTTOM HOLE LOCATION OF

- G2 DRILLED AS VERTICAL HOLE . OO BOTTOM HOLE LOCATION

-G2 LOCATION OF WELL PENETRATING SALT.

-SALT DEPTH CONTOURS

$1000 \quad 600 \quad 0$ 1000 2000 DISTANCE IN FEET
BIG HILL SALT DOME STRUCTURE MAP-SALT (1) Sandia

T. R. MAGORIAN

SEP 1981

FIG. 5-1 


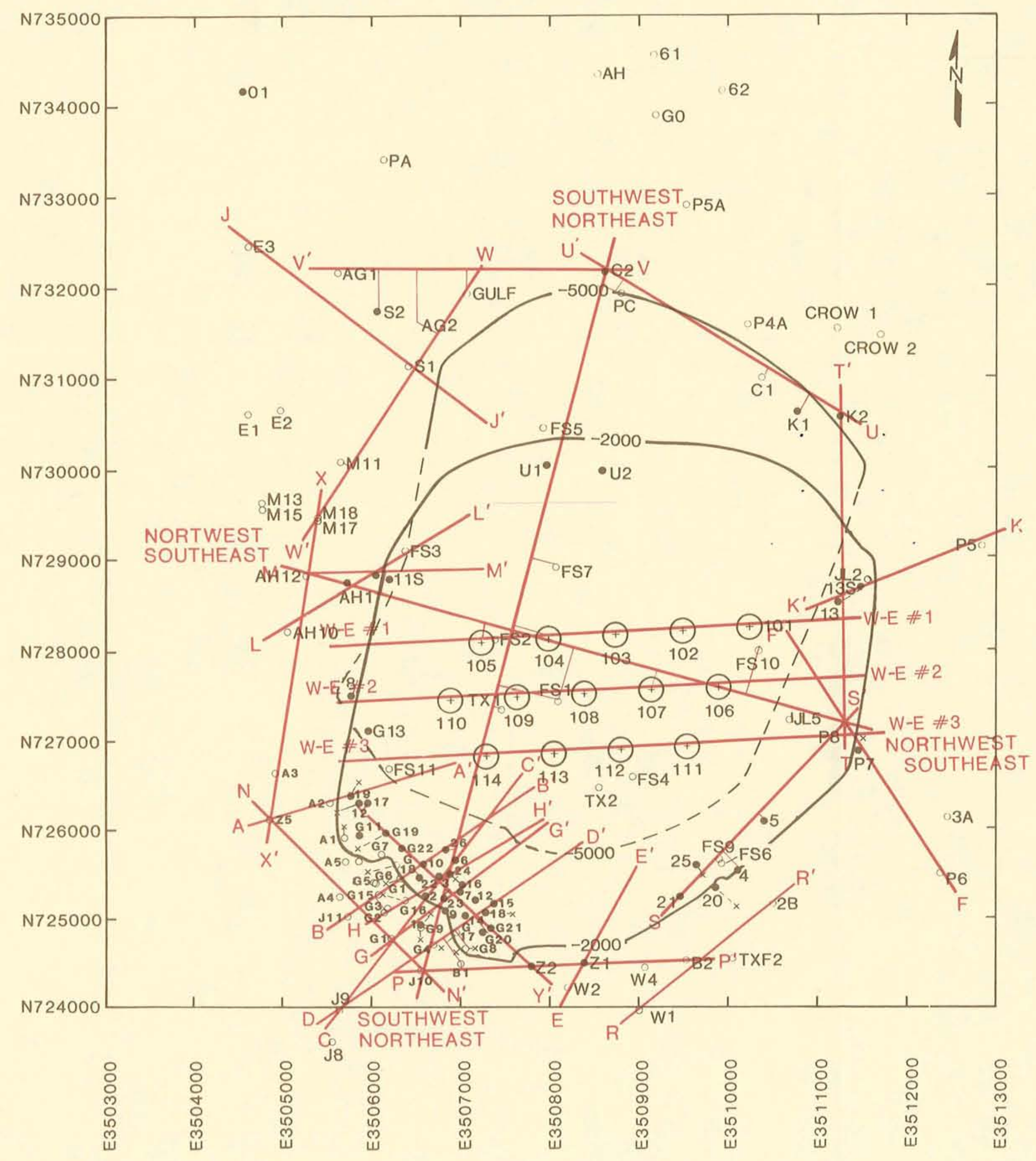

NOTES

SEE APPENDIX B FOR EXPLANATION OF WELL NUMBERS AND WELL LOCATIONS. LEGEND

• UI UNION OIL LPG CAVERN

SURFACE LOCATION OF WELI.

- BOTTOM HOLE LOCATION OF WELL.

GQ
G2 BOTTOM HOLE LOCATION OF
SIDETRACK HOLE

G2 DRILLED AS VERTICAL HOLE. NO BOTTOM

( PROPOSED SPR CAVERNS

101 SECTION LINE

WELLS PROJECTED TO SECTION LINE

$1000500 \quad 0$

DISTANCE IN FEET
BIG HILL SALT DOME

SECTION REFERENCE MAP IV A National 


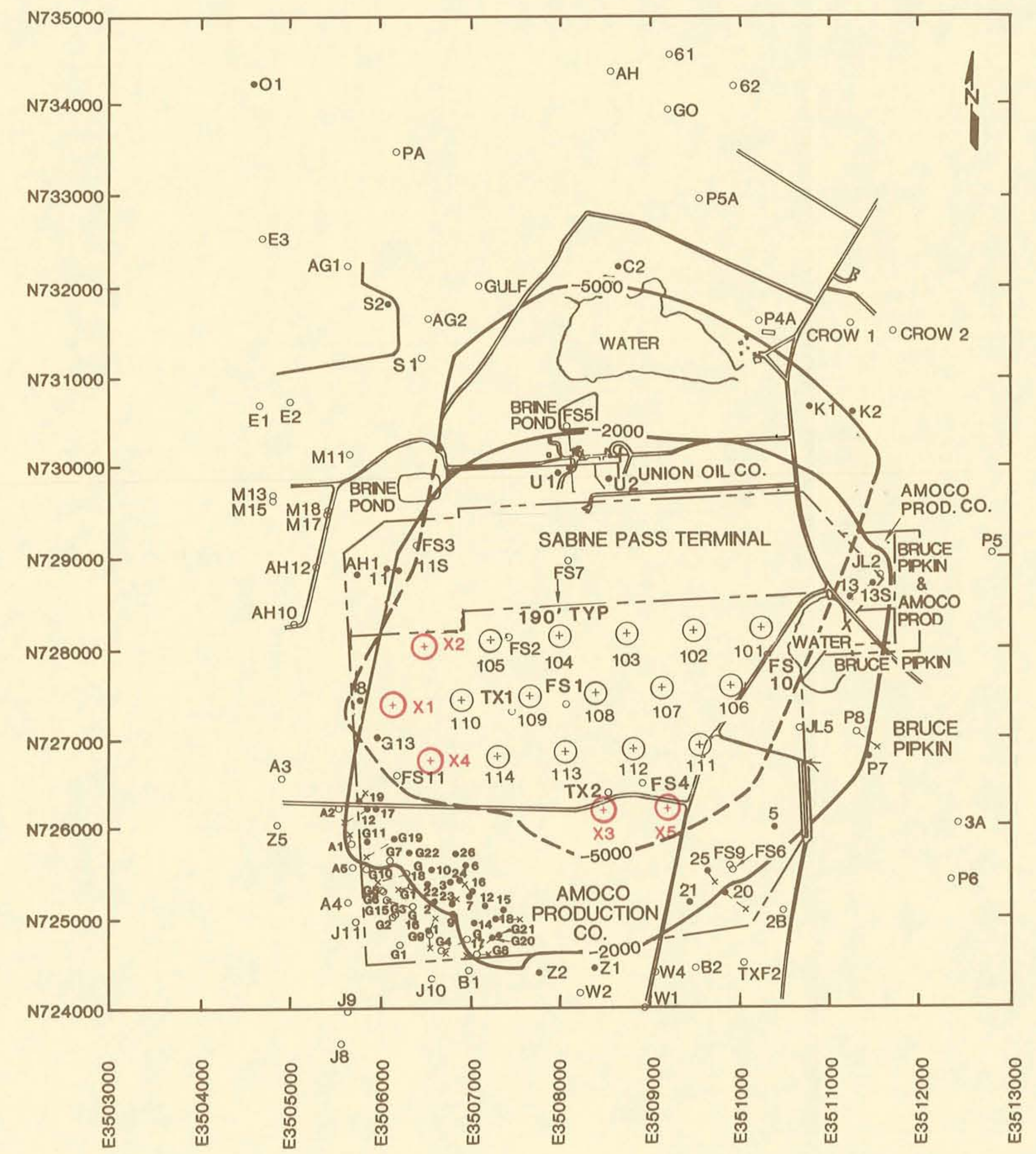

CAVERN LOCATION TABLE

CAV \# NORTH EAST

$\begin{array}{llll}101 & 728250.45 & 3510231.68\end{array}$

$\begin{array}{lll}102 & 728214.66 & 3509482.52\end{array}$

$\begin{array}{llll}103 & 728178.87 & 3508733.39\end{array}$

$104 \quad 728143.09 \quad 3507984.23$

$105 \quad 728107.30 \quad 3507235.09$

$106 \quad 727583.79 \quad 3509888.10$

$\begin{array}{llll}107 & 727548.00 & 3509138.95\end{array}$

$\begin{array}{llll}108 & 727512.21 & 3508389.79\end{array}$

$\begin{array}{llll}109 & 727476.43 & 3507640.64\end{array}$

$110 \quad 727440.65 \quad 3506891.51$

$111 \quad 726917.14 \quad 3509544.51$

111.750975

$12 \quad 726881.34$ 3508795.35

$113 \quad 726845.56 \quad 3508046.23$

$\begin{array}{lllll}114 & 726809.77 & 3507297.08\end{array}$

X1 $727404.86 \quad 3506142.36$

X2 $728071.52 \quad 3506485.95$

$\begin{array}{rrr}X 3 & 726214.68 & 3508451.79 \\ \times 4 & 726773.99 & 3506547.09\end{array}$

X5 726250.463509201 .77

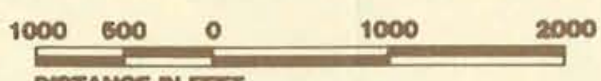

POTENTIAL EXPANSION CAVERN LAYOUT BIG HILL SALT DOME

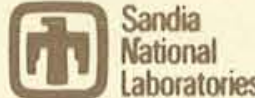




\section{Sandia Laboratories}

date: December 2, 1981

Albuquerque. New Mexico

to: Distribution

from: 3. F. Nely, 4543
f.

subject: Replacement Pages for Strategic Petroleum Reserve (SPR) Geological Site Characterization Report Big Hill salt Dome, SAND81-1045

The color overlays of Figures 5-1, 5-2, and 6-5 were shifted slightly when printed the first time. Therefore, we have had these figures reprinted and have enclosed them for your use. Please remove the old Figures 5-1, 5-2, and 6-5 and replace them with the new ones.

We are sorry for any inconvenience this may cause you.

TSO : 4543 : jmu 


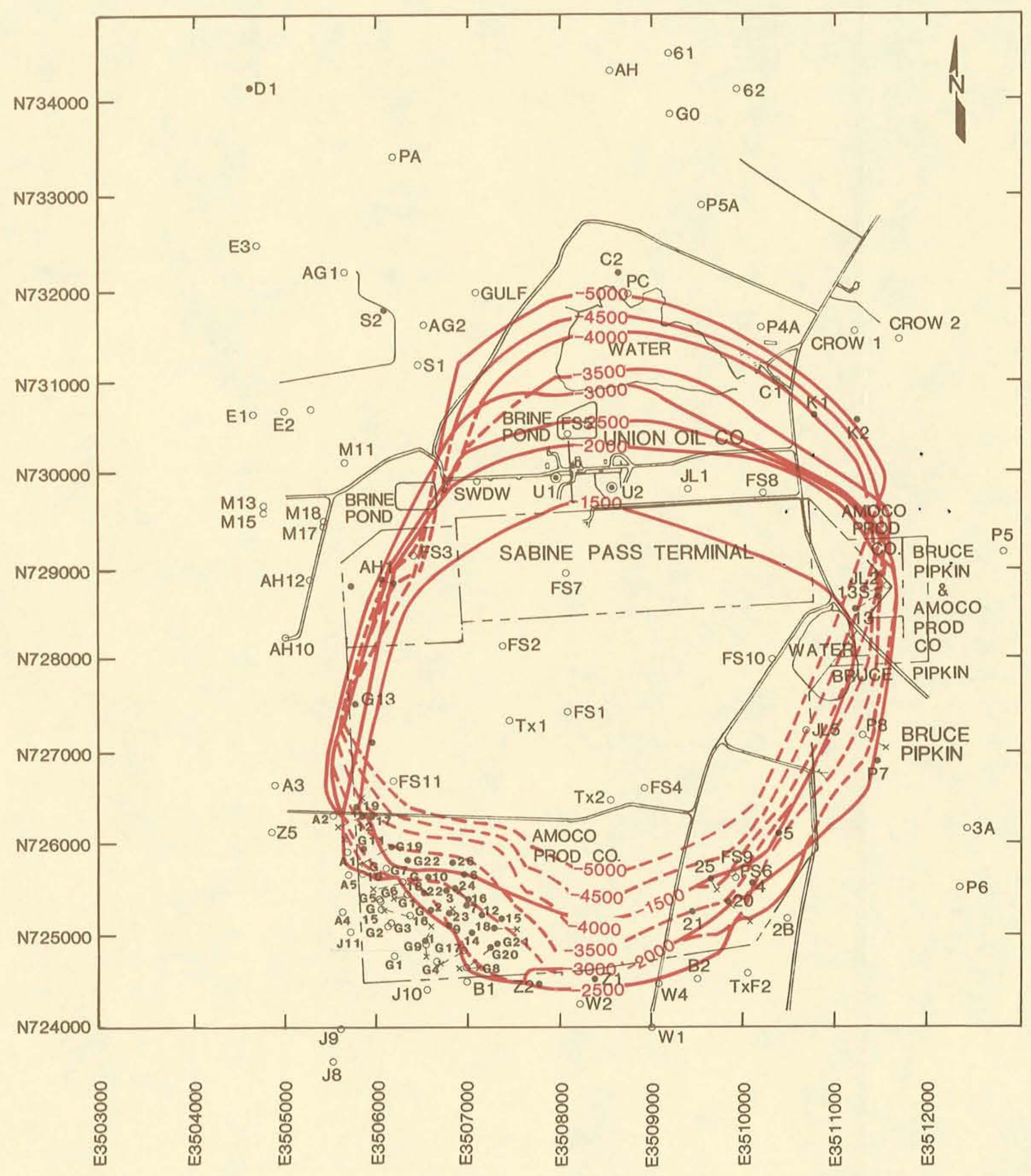

NOTES

1. SEE APPENDIX BFOR EXPLANATION OF WELL NUMBERS AND

WELL LOCATIONS.

2. CONTOURED DEPTHS MEASURED IN FEET BELOW DRILLING FLOOR. LEGEND

- U1 UNION OIL LPG CAVERN.

$+\quad$ SURFACE LOCATION OF WELL.

-G2BOTTOM HOLE LOCATION OF WELL.

-G2 BOTTOM HOLE LOCATION OF SIDETRACK HOLE.

- G2 DRILLED AS VERTICAL HOLE NO BOTTOM HOLE LOCATION

- G2 LOCATION OF WELL PENETRATING SALT.

-SALT DEPTH CONTOURS

$1000 \quad 600 \quad 0$ 2000

DISTANCE IN FEET

BIG HILL SALT DOME STRUCTURE MAP-SALT (1) National

T. R. MAGORIAN

SEP 1981 


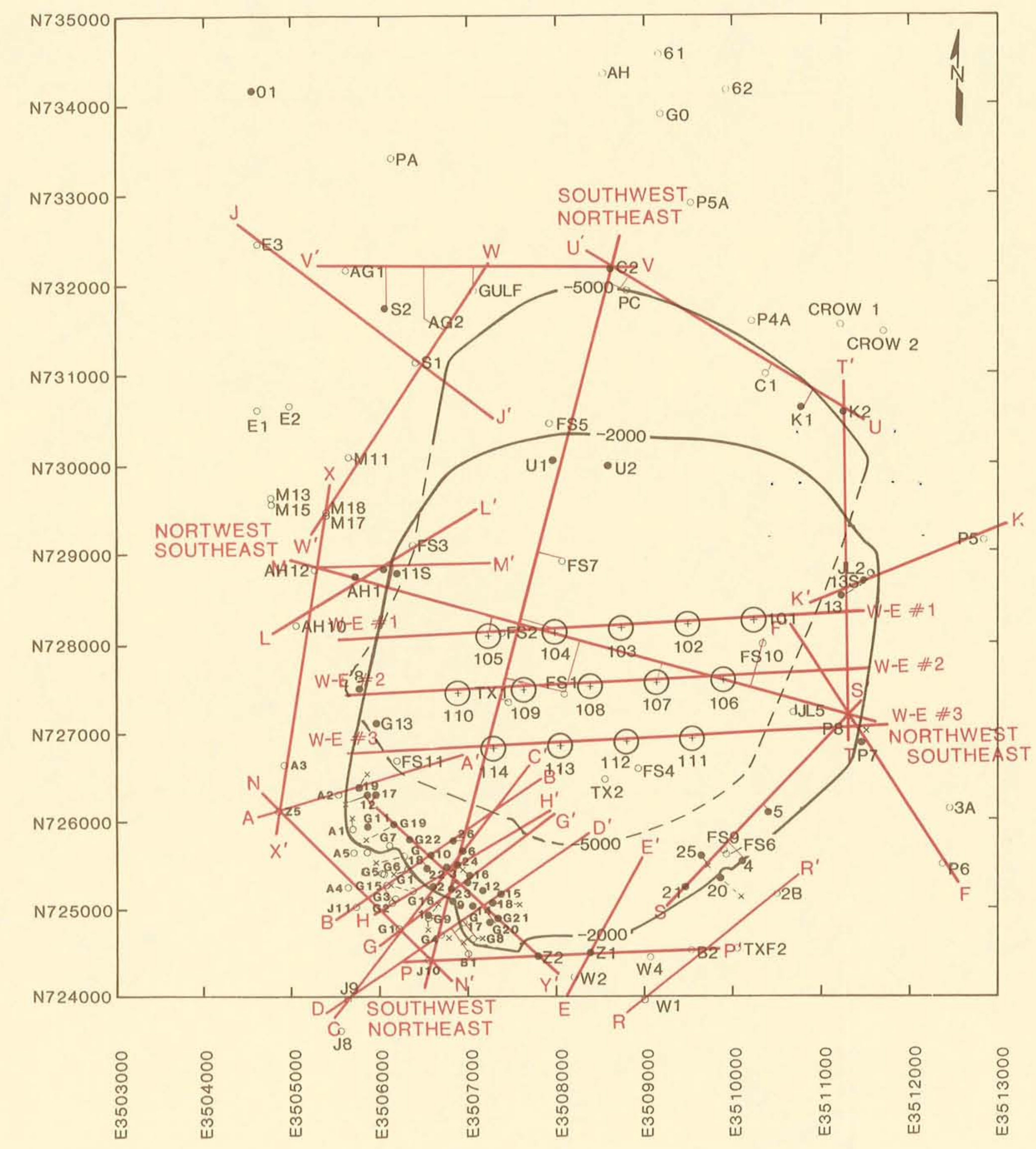

NOTES

SEE APPENDIX B FOR EXPLANATION OF WELL NUMBERS AND WELL LOCATIONS.

$$
\text { LEGEND }
$$

- UI UNION OIL LPG CAVERN

SURFACE LOCATION OF WELI.

- BOTTOM HOLE LOCATION OF WELL.

dG2 BOTTOM HOLE LOCATION OF

G2 DRILLED AS VERTICAL HOLE. NO BOTTOM

G2 DRILLED LOCATION AVAILABLE

P PROPOSED SPR CAVERNS

101 SECTION LINE

WELLS PROJECTED TO SECTION LINE

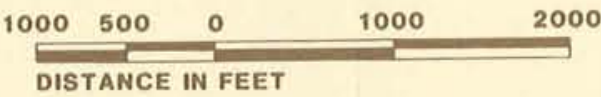

BIG HILL SALT DOME SECTION REFERENCE MAP Ii A. Sational 


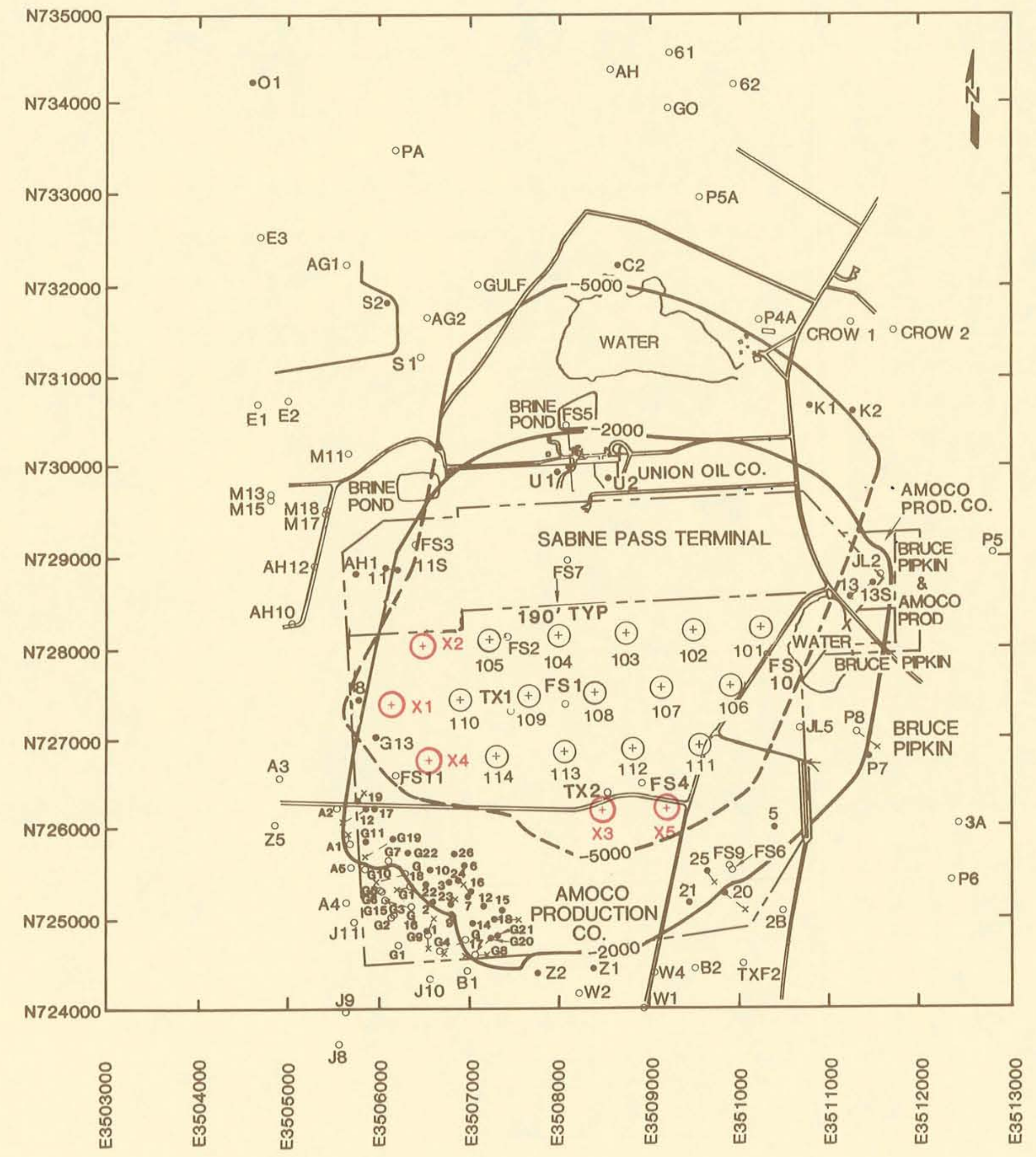

CAVERN LOCATION TABLE

CAV * NORTH EAST

$\begin{array}{llll}101 & 728250.45 & 3510231.68\end{array}$

$\begin{array}{lll}102 & 728214.66 & 3509482.52\end{array}$

$\begin{array}{llll}103 & 728178.87 & 3508733.39\end{array}$

$\begin{array}{llll}104 & 728143.09 & 3507984.23\end{array}$

$\begin{array}{lll}105 & 728107.30 & 3507235.09\end{array}$

$\begin{array}{llll}106 & 727583.79 & 3509888.10\end{array}$

$\begin{array}{llll}107 & 727548.00 & 3509138.95\end{array}$

$\begin{array}{llll}108 & 727512.21 & 3508389.79\end{array}$

$\begin{array}{llll}109 & 727476.43 & 3507640.64\end{array}$

$110 \quad 727440.65 \quad 3506891.51$

$111 \quad 726917.14$

11120.726917 .143509544 .51

112726881.34 3508705.35

$\begin{array}{lllll}113 & 726845.56 & 3508046.23\end{array}$

$\begin{array}{llll}114 & 726809.77 \quad 3507297.08\end{array}$

$X 1727404.86 \quad 3506142.36$

$\times 1728071.523506485 .95$
$\times 3726214.68$

$X 3$
$\times 326214.68 \quad 3508451.79$

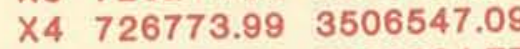

$\times 5726250.46 \quad 3509201.77$

$1000 \quad 600 \quad 0$

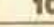

DETANCE WN WTI
POTENTIAL EXPANSION

CAVERN LAYOUT

BIG HILL SALT DOME

ivi National

SEP 1981 
SAND81-1045

Unlimited Release

Printed September 1981

Distribution

Category: UC-94e

STRATEGIC PETROLEUM RESERVE (SPR)

GEOLOGICAL SITE CHARACTERIZATION REPORT

BIG HILL SALT DOME

\author{
R. J. Hart \\ Terri S. Ortiz \\ SPR Geotechnical Division \\ Sandia National Laboratories \\ A7buquerque, NM 87185 \\ Thomas R. Magorian \\ Consulting Geologist-Geophysicist \\ Amherst, NY
}




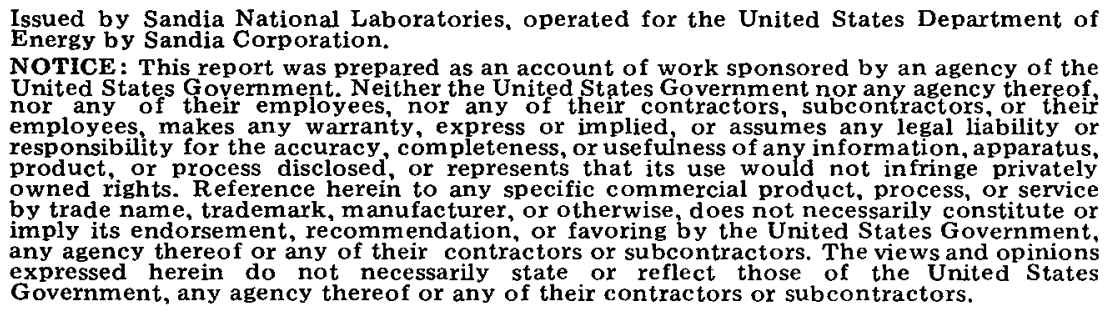

Issued by Sandia National Laboratories, operated for the United States Department of NOTICE: This report was prepared as an account of work sponsored by an agency of the United States Government. Neither the United States Government nor any agency thereof, employees makes any warranty, express or implied or assumes any legal liability or responsibility for the accuracy complet product, or process disclosed, or represents that its use would not infringe privately by trade name, trademark, manufacturer, or otherwise, does not necessarily constitute or any agency there of or any of their contractors or subcontractors. The views and opinions Government, any agency thereof or any of their contractors or subcontractors.

Printed in the United States of America

Available from

National Technical Information Service

U.S. Department of Commerce

5285 Port Royal Road

Springfield, VA 22161

NTIS price codes

Printed copy: $\$ 10.00$

Microfiche copy: A01 


\section{CONTENTS}

Page

Glossary of Abbreviations 9

CHAPTER 1 - SUMMARY AND RECOMMENDATIONS $1-1$

Sumliary $1-1$

Introduction $1-1$

Local Geology and Hydrology $1-2$

Cap-Rock Geology and Hydrology 1-2

Salt-Dome Geology $7-2$

Cavern Locations and Geotechnical Considerations $\quad 7-3$

Natural Hazards 1-4

Recommendations 1-4

CHAPTER 2 - INTRODUCTION 2-1

Purpose and Scope of Study 2-7.

Data Acquisition and Analysis $2-2$

Site History $2-2$

Hydrocarbon Exploration $2-2$

Sulphur Exploration $2-2$

Union 0i1 Storage Caverns $2-3$

CHAPTER 3 - LOCAL GEOLOGY AND HYDROLOGY 3-1

Physiography $3-1$

Geologic Setting 3-1.

Geologic History 3-2

Eocene $3-2$

01 igocene $3-2$

Miocene 3-2

Pliocene $3-3$

Pleistocene 3-3

Regional Structure 3-4

Soils $3-5$

Hydrology 3-6

CHAPTER 4 - CAP-ROCK GEOLOGY AIND HYDROLOGY 4-1

Cap-Rock Geology 4-1

Cap-Rock Lithology 4-7.

Cap-Rock Structure and Geometry 4-2.

Cap-Rock Hydrology $\quad 4-2$

Lost Circulation 4-2

Casing Corrosion Potential 4-3 
CONTENTS (Cont)

Page

CHAPTER 5 - SALT-DOME GEOLOGY 5-1

Origin of the Dome $5-1$

Dome Geometry 5-1

Geological Interpretation $5-2$

Wel1 Control 5-3

Seismic Interpretation 5-4

Structure and Stratigraphy $5-5$

Major Cross Sections $5-5$

Radial Sections $5-7$

Tangential Sections $5-9$

Structure Contour Maps $5-11$

Dome-Related Faulting 5-11

Salt Mineralogy $5-12$

CHAPTER 6 - CAVERN LOCATIONS AND GEOTECHNICAL CONSIDERATIONS $6-1$

Cavern Layout and Design Criteria 6-1

Pillar-to-Diameter (P/D) Ratio 6-2

Salt Roof Thickness-to-Diameter (S/D) Ratio 6-3

Edge of Cavern to Edge of Dome (E) 6-4

Edge of Cavern to Property Line 6-4

Baseline Cavern Layout $\quad 6-5$

Potential Expansion Cavern Layout 6-5

Exploratory Extension of Cavern Wells 6-6

Well-Logging and Coring Program 6-6

Material Properties Program 6-8

CHAPTER 7 - NATURAL HAZARDS 7-1

Subsidence $\quad 7-1$

Earthquakes $\quad 7-1$

Faulting 7-7

Floods and Hurricanes $\quad 7-2$

APPENDIX A - References and Bibliography A-1

APPENDIX B - We11 Data and We11 Control B-1

APPENDIX C - List of Contacts C-1 
FIGURES

\section{Figure}

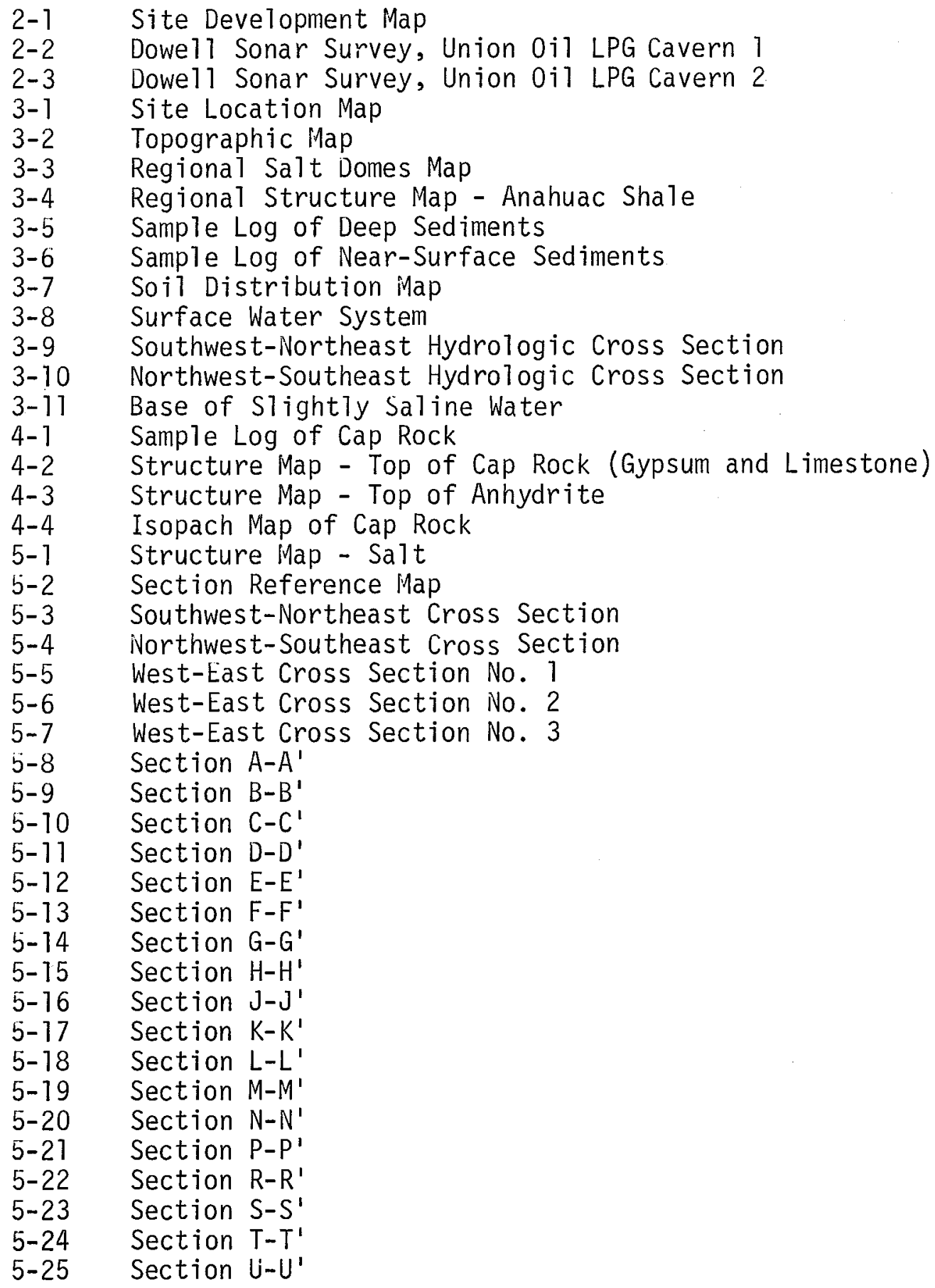


FIGURES (Cont)

Figure

$\begin{array}{ll}5-26 & \text { Section V-V' } \\ 5-27 & \text { Section W-W' } \\ 5-28 & \text { Section X-X' } \\ 5-29 & \text { Section Y-Y' } \\ 5-30 & \text { Structure Map - A Sand } \\ 5-31 & \text { Structure Map - B Sand } \\ 5-32 & \text { Structure Map - C Sand } \\ 5-33 & \text { Structure Map - D Sand } \\ 5-34 & \text { Structure Map - E Sand } \\ 5-35 & \text { Structure Map - Anahuac Shale } \\ 5-36 & \text { Seismic Profile Reference Map } \\ 6-1 & \text { Depth vs Secondary Creep Rate } \\ 6-2 & \text { Cavern Design and Location } \\ 6-3 & \text { Cavern-to-Property Line Spacing } \\ 6-4 & \text { Baseline Cavern Layout } \\ 6-5 & \text { Potential Expansion Cavern Layout } \\ 6-6 & \text { East-West Cross Section No. } 1 \\ 6-7 & \text { East-West Cross Section No. } 2 \\ 6-8 & \text { East-West Cross Section No. } 3 \\ 6-9 & \text { Exploratory Extension of Cavern We11s } \\ 7-1 & \text { Seismic Risk Map } \\ 7-2 & \text { 100-Year Flood-Hazard Map } \\ 7-3 & \text { Inundation by Hurricanes Carla and Beulah }\end{array}$

TABLES

Table

Page

3-1 Geologic Timetable $3-9$

3-2 Big Hill SPR Site Tertiary Geologic Units

$3-10$

Big Hill SPR Site Hydrologic Units

3-4 Water Levels in Wells at Big Hill, 1951-1965

$3-11$

3-5 Summary of Aquifer Tests, Upper Chicot

$3-12$

$3-6$

Cap-Rock Drilling Summary

$3-13$

$3-14$

$4-4$ 


\section{GLOSSARY OF ABBREVIATIONS}

$\begin{array}{ll}\text { AB } & \text { Amphistigina "B" } \\ \text { bD1 } & \text { barrels } \\ \text { DOE } & \text { US Department of Energy } \\ \text { DR } & \text { Discorbis (restricted) } \\ \text { EPA } & \text { Environmental Protection Agency } \\ \text { fPS } & \text { feet per second } \\ \text { HUD } & \text { Department of Housing and Urban Development } \\ \text { ICW } & \text { Intracoastal Waterway } \\ \text { LPG } & \text { liquefied-petroleum gas } \\ \text { MHB } & \text { million barrels } \\ \text { mg/L } & \text { milligrams per litre } \\ \text { MS1 } & \text { mean sea level } \\ \text { NOAA } & \text { National Oceanic and Atmospheric Administration } \\ \text { P/D } & \text { pillar-to-diameter ratio } \\ \text { PPM } & \text { parts per million } \\ \text { RL } & \text { Robulus "L" } \\ \text { SD } & \text { Siphonina davisi } \\ \text { S/D } & \text { Salt roof thickness-to-diameter ratio } \\ \text { SINL } & \text { Sandia National Laboratories } \\ \text { SPR } & \text { Strategic Petroleum Reserve } \\ \text { USGS } & \text { US Geological Survey } \\ \text { WIPP } & \text { Waste Isolation Pilot Project }\end{array}$


$-$ 
CHAPTER 1 - SUMMARY AND RECOMMENDATIONS

Summary

Introduction

Sandia National Laboratories is responsible for the geotechnical program of the Strategic Petroleum Reserve (SPR) project for the Department of Energy (DOE). The overall scope of the Sandia program includes geological characterization of a1l existing and planned SPR sites. Development of 140 million idarrels (MinB) of storage capacity in the Big Hill salt dome is planned as part of the SPR expansion to achieve 750 MMB of storage capacity.

This Phase 1 geological characterization of the Big Hill salt dome was done in association with $\mathrm{Dr}$. Thomas R. Magorian, consulting geologist and geophysicist who provided the geological and geophysical analyses and interpretations that define the salt and the surrounding geology. Objectives of the study were to

1. Acquire, evaluate, and interpret existing data pertinent to geological characterization of the Big Hill dome

2. Characterize the surface and near-surface geology and hydrology

3. Characterize the geology and hydrology of the overlying cap rock

4. Define the geometry and geology of the dome

5. Determine the feasibility of locating and constructing 14 10-MMB storage caverns in the south portion of the dome

6. Assess the effects of natural hazards on the SPR site

The Big Hill salt dome in southwestern Jefferson County, Texas, was discovered in 1901 when the first oil exploration hole (a dry hole) was drilled into cap rock. The first producing well was drilled into the flank of the dome in 1923, but commercial production did not begin until 1949. No significant amount of $0 i 1$ or gas has been found in the cap rock overlying the dome. The Big Hill dome has been extensively explored for sulphur since 1917, but none has been produced. Through 1975, cumulative oil and gas production associated with the dome was 15,030,000 barrels (bb1) and 55,559 million cubic feet, respectively (Halbouty, 1979). A few producing wells on the southwest flank of the dome continue in operation. 
The Union $0 i 1$ Company operates two 1iquefied-petroleum gas (LPG) storage caverns on the northern part of the dome. The capacity of these two caverns, which were leached in 1957 and 1960, is $\sim 400,000$ bbl each.

Local Geology and Hydrology

Big Hill salt dome is $\sim 20 \mathrm{mi}$ southwest of Port Arthur, Texas, and $5.3 \mathrm{mi}$ north of the Intracoastal Waterway (ICW). The surface expression of the dome is a mound $\sim 1 \mathrm{mi}$ in diameter rising to a maximum elevation of $37 \mathrm{ft}$ mean sea level (msl), or $27 \mathrm{ft}$ above the surrounding flat terrain. The soils at the site are Pleistocene silty loams and clays.

The site is within the Gulf Coast geosyncline, which is characterized by a thick accumulation of sediments. Big Hill, like other salt domes, formed as a result of plastic upward movement of deeply buried salt initiated by the tremendous weight of the denser overlying sediments.

Faulting in the region occurs on two scales: (1) large-scale regional faulting, or growth faulting associated with basin fill, and (2) smali-scale, localized faulting associated with the growth of salt domes.

The surface water system at the site includes two freshwater ponds and a good drainage system. In addition, Union $0 i 1$ Company has two brine ponds at Big Hil1. Water for brining the SPR caverns will be taken from the Intracoastal Waterway to the south of the site (PB/KBB, 1979).

The subsurface hydrologic units near the site are the Miocene Burkeville aquiclude, the Pliocene Evangeline aquifer containing saline water, and the Pleistocene Chicot aquifer containing fresh water at very shallow depths grading to saline water with depth.

Cap-Rock Geology and Hydrology

The cap rock at Big $\mathrm{Hill}$ is comprised of two distinct layers: an upper layer of limestone and gypsum, and a lower layer of anhydrite. The top of the cap rock is roughly dome-shaped, rounded on top and steepening at the edges. Near the periphery of the dome the top of the cap rock is encountered below a depth of $1000 \mathrm{ft}$. Over the center of the dome, the cap rock is encountered at a depth of $<300 \mathrm{ft}$. The thickness of the cap rock at Big Hi11 varies from 850 to $1350 \mathrm{ft}$, making it one of the thickest known cap rocks of the Gulf Coast salt domes. The cap rock at Big Hill is vuggy, and the lithology is complex. Faults and fractures caused by dissolution of the salt and collapse at the salt/cap-rock interface result in a highly permeable, discontinuous unit. Drilling logs indicate difficulty with stuck tools and with lost circulation (Table 4-1).

\section{Salt-Dome Geology}

Because of sparse drillhole data, geological interpretative methods based on strata convergence and faulting were used to define the geometry of 
the Big Hill salt dome. Interpretation of the dome geometry and surrounding geology was based on four seismic profiles and on 145 wells drilled on and around the dome, 46 of which penetrated salt.

The Big Hill dome is shaped like a cylindrical column tilted to the south. The top of the salt 1 ies between 1300 and $1800 \mathrm{ft}$ below the surface. The north flank of the dome dips gently downward to $2000 \mathrm{ft}$, where the dip increases to $60^{\circ}$ between 2000 and $10,000 \mathrm{ft}$. The south flank is overhung below $2000 \mathrm{ft}$ at about $60^{\circ} \mathrm{dip}$. Both the east and west sides at the center of the dome are nearly vertical.

The Big Hill dome is overlain with Pleistocene sediments. Sediments flanking the dome are steeply dipping sands and shales of Pliocene, Miocene, and 01 igocene age. Sediments around the dome have been faulted by radial and tangential faults caused by the upward movement of the dome.

Big Hill shows a consistent history of central domal uplift without the formation of any large rim synclines or other evidence of salt exhaustion or stagnation.

\section{Cavern Locations and Geotechnical Considerations}

The SPR Phase III expansion program calls for constructing 140 MMB of storage capacity at Big Hill. The objective of the cavern location study was to determine the feasibility of constructing 14 10-MMB caverns on the south part of the dome by using the dome definition developed in this site characterization study, the DOE-specified guidelines, and the geotechnical criteria necessary to assure cavern structural integrity and stability.

Caverns $270 \mathrm{ft}$ in diameter and $2000 \mathrm{ft}$ high at the end of five withdrawal cycles were assumed, based on SPR Phase II cavern leaching analyses. The following geotechnical criteria for cavern design were used:
Pillar-to-Diameter (P/D) Ratio
Salt Roof Thickness-to-Diameter (S/D) Ratio
51.78
Edge of Cavern-to-Edge of Dome
$>1.0$
$>300 \mathrm{ft}$

Based on these geotechnical criteria and a cavern-to-property-1ine spacing of $190 \mathrm{ft}$, we determined that it is feasible to construct 14 10-MMB caverns on the south part of the dome. No separate exploratory-well or geophysical programs are required to proceed with cavern construction, according to this baseline cavern layout. Because of the sparse data forming the basis of geological interpretations of the salt contours, an exploratory extension of tinree of the cavern wells combined with a comprehensive well-logging and coring program are required to dispel uncertainties about the distance to the edge of the dome at the bottom of the caverns.

The potential for expanding the Big Hill site by constructing additional caverns was also investigated. The results of that study indicate that, with some additional exploration, the number of caverns on the site can be expanded to 19. 
Natural Hazards

Ground water withdrawal in the area has caused some minor, regional subsidence $(0.2$ to $1 \mathrm{ft}$ ); and minor subsidence because of $0 i 1$ withdrawal around the periphery of the dome can be expected. However, it appears that subsidence of this type will pose no threat to SPR facilities. The possibility of subsidence caused by formation of the storage caverns has not yet been adequately determined.

The ivational Oceanic and Atmospheric Administration (NOAA) has classified the Big Hill area as having no reasonable expectancy of seismic risk. The two types of faults that occur in the area, regional growth faults and faults related to the upward movement of the salt dome, are both considered aseismic. Movement along these faults is gradual and should have no adverse effect on the site.

The 100-yr flood plain in the Big Hill area covers land up to $15 \mathrm{ft} \mathrm{msl}$, completely encircling Big Hill. Hurricane-induced flooding could be somewhat nigher because of the added impact of storm surge.

\section{Recommendations}

To ensure that SPR storage caverns at Big Hill meet the desired standards for structural integrity and stability at the lowest overall cost, the following recommendations are made.

1. Because of the high sulfate ion concentration in the groundwater at $\mathrm{Big} \mathrm{Hill}$ and its corrosive nature, we recommend the use of sulfate-resistant cement in the casing program.

2. We recommend application of the geotechnical criteria specified in Chapter 6 to the design and construction of the caverns, and location of the caverns as shown in Figure 6-2, 6-3, and 6-4. These criteria are:

$$
\begin{aligned}
& P / D=1.78 \\
& S / D=1.0 \\
& \text { Cavern-to-Dome Edge }=300 \mathrm{ft} \\
& \text { Cavern-to-Property 1ine }=190 \mathrm{ft}
\end{aligned}
$$

3. We recommend implementation of the exploratory extension drilling and coring program outlined in Chapter 6 for one of the we11s for Caverns 101, 111, and 114 as shown in Figure 6-9.

4. We recommend, as a part of the cavern well-drilling program, the implementation of a comprehensive well-logging and coring program and a cap-rock water sampling program, as outlined in Chapter 6. 
5. We recommend a comprehensive materials test program, as out1 ined in Chapter 6 , to support the cavern leaching plan and the analytical efforts to evaluate structural stability and long-term creep of the caverns.

6. We recommend design and construction of the surface facilities of the site, including wellheads, to withstand potential effects of hurricanes.

7. We recommend location of all surface facilities at elevations above the 100-yr flood plain as shown in Figure 7-2, or their construction to withstand flooding.

8. We recommend updating the site characterization as data from future development and/or exploration of the dome become available, and addition of a section on materials properties when the results of the materials test program become available. 
CHAPTER 2 - INTRODUCTION

Purpose and Scope of Study

Sandia National Laboratories is responsible for the geotechnical program of the Strategic Petroleum Reserve (SPR) project for the Department of Energy (DOE). The overall scope of the program includes all geotechnical investigations needed to support continued SPR development. Among these investigations is a comprehensive geological characterization of all existing and planned SPR sites. The Big Hill salt dome has been proposed as part of the SPR expansion program from 500 MMB to 750 MMB of storage capacity. This report is the Phase 1 geological characterization of the Big Hill salt dome/SPR Site. Phase 1 consists of the compilation, analysis, and interpretation of existing geological and geophysical data.

Specific tasks associated with preparation of this Phase I report were as follows:

1. Acquisition, evaluation, and interpretation of existing data for the geological characterization of the Big Hill dome. A11 known data from public and private sources were obtained under this task.

2. Characterization of the surface and near-surface regional and local geology and hydrology with respect to its impact on SPR objectives and facilities.

3. Characterization of the geology, hydrology, and mineralogy of the cap rock overlying the dome.

4. Characterization of the salt dome, including mapping of its boundaries to the depths of concern for storage cavern construction.

5. Determination of the feasibility of constructing 14 10-MMB storage caverns on the south part of the dome by using the geotechnical criteria necessary to assure cavern structural integrity and stability.

6. Assessment of the effects of natural events (i.e., hurricanes, earthquakes, and natural subsidence) on the SPR site. 
Data Acquisition and Analysis

Two previous reports on the Big Hill dome have been prepared during the course of the SPR program (PB/KBB, 1979 and Fenix \& Scisson, 1973). $\mathrm{PB} / \mathrm{KBB}$ included preliminary geotechnical investigations, and Fenix \& Scisson addressed the feasibility of the Big Hill salt dome as an SPR site. To avoid duplication of effort, these two previous studies and associated data and analyses were reviewed and used as a starting point for this study. ilost of the work presented in this report continues and expands these previous studies, with the objective of providing a comprehensive geologic characterization of Big Hi11. Data from AMOCO Texas Exploration Well 26, which was drilled in a strategic location has become available since the Conceptual Design Study was prepared. All well logs have been analyzed to accurately define the critical geometry of the salt and cap rock and the geology surrounding the dome. A11 analyses and data interpretations were based on existing material collected from other sources.

Site History

Unlike the other SPR sites, no brine-production wells have been drilled at Big Hill. Therefore, all SPR caverns will be formed especially to store crude oil. Hydrocarbons have been developed around the periphery of the dome, and considerable unsuccessful sulphur exploration has been carried out in the cap rock. In addition, two small storage caverns are operating in the northern part of the dome. Figure $2-1$ is a site development map showing locations of all the wells and the two storage caverns.

\section{Hydrocarbon Exploration}

The topographic high at Big $H i l l$ was recognized as a potential salt dome by J. M. Guffey, who drilled the first well to cap rock in 1901. It was a dry hole. (Guffey later discovered oil at Spindletop dome.) In 1923, Houston $0 i 1$ Company drilled the first producing well. Although several wells were later drilled that showed signs of oil, the first commercial production was not until 1949 (Dollison, 1965). A drilling program to define the Miocene and 01 igocene reservoirs followed. Most of the Miocene production has come from the overhang area on the southwest flank. Cumulative production of $0 i 1$ through 1975 was $15,030,000 \mathrm{bbl}$, and total production of gas was $55,559 \mathrm{mi11}$ ion cubic feet (Halbouty, 1979).

\section{Sulphur Exploration}

Although there has been extensive sulphur exploration at Big Hill, no sulphur has been produced. Texas Exploration Company drilled four holes into the cap rock in 1917-18, with two reports of uneconomic quantities of sulphur. In 1927-28, Freeport Sulphur Company drilled 16 exploratory sulphur wells without locating economic deposits. Jefferson Lake Sulphur Company drilled five holes in 1962, again finding no economic quantity of sulphur. 


\section{Union 0i1 Storage Caverns}

Union $0 i 1$ Company operates two LPG (isobutane and normal butane) storage caverns on the northern part of the dome (Figure 2-1). Cavern 1 was leacned in 1957 by the Pure $0 i 1$ Company (presentiy the Union $0 i 1$ Company). A 9-5/8-in. production casing was cemented to $-1998 \mathrm{ft}$, wnicin is $328 \mathrm{ft}$ into the salt. The cavern was leached through 7-in. and 5-in. strings. The 7-in. string was later removed and the 5-in. string left in place as a brine production string for product recycling. A leak in 1971 above the top of the salt resulted in a loss of butane. A new cemented 7-in. casing solved the problem. The latest sonar survey, which was run in 1978 (see Figure 2-2), showed the cavern as almost cylindrical and extending from 2650 to $3430 \mathrm{ft}$ below the surface, with a maximum diameter of $\sim 90 \mathrm{ft}$. Total volume in 1978 was $406,000 \mathrm{bbl}$. The salt roof over the cavern was $980 \mathrm{ft}$ thick.

Cavern 2 was leached by the Pure $0 i 1$ Company in 1960 to store propane. The wel1 was cased by using 16-in. and 13-3/8-in. casings with the 13-3/8 in. set at $-2288 \mathrm{ft}, 588 \mathrm{ft}$ into the salt. The cavern was leached through 10-3/4 in. and 7-in. suspended casings. Both strings were removed and replaced by an $8-5 / 8-i n$. string to be used as the brine string during propane cycling. The 8-5/8-in. casing has been replaced at least once because of corrosion; the cemented casings have remained pressure-tight. The latest sonar survey on this cavern was run in 1978 (Figure 2-3) and indicated that the top of the cavern was $2602 \mathrm{ft}$ below the surface, and the bottom $3203 \mathrm{ft}$ below the surface with a maximum diameter of $100 \mathrm{ft}$ and a total volume of 403,000 bbl. The salt roof was $900 \mathrm{ft}$ thick, and the cavern was nearly cylindrical.

Propane withdrawal from both storage caverns is done with nearly saturated brine; growtin of the caverns since the sonar surveys of 1978 should therefore be minimal. 


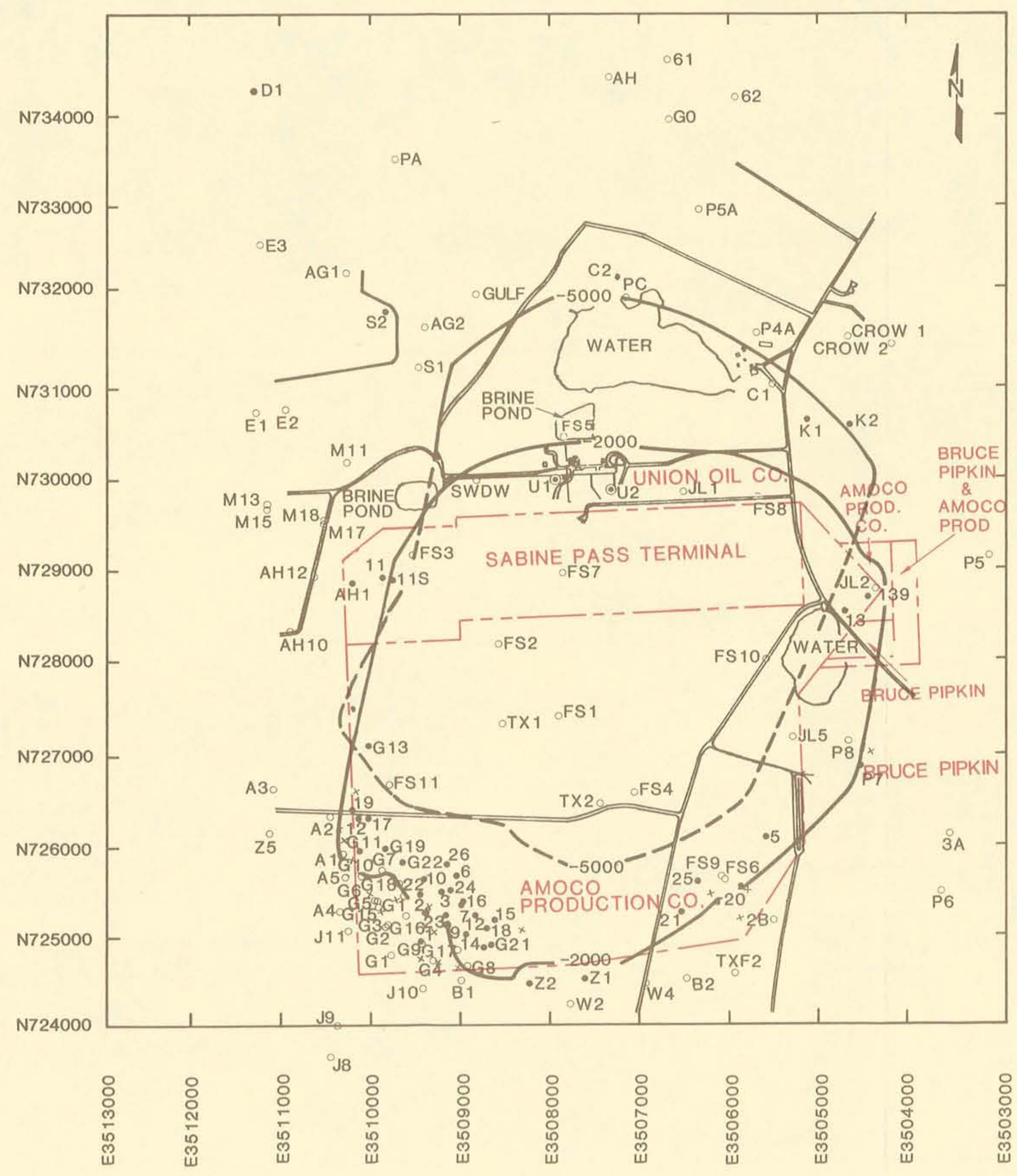

\section{NOTES}

1. SEE APPENDIX B FOR EXPLANATION OF WELL NUMBERS AND WELL LOCATIONS LEGEND

-U1 UNION OIL LPG CAVERN.

SURFACE LOCATION OF WELL.

- G2 BOTTOM HOLE LOCATION OF WELL.

-G2 BOTTOM HOLE LOCATION OF

SIDETRACK HOLE.

G2 DRILLED AS VERTICAL HOL.E. NO

- g2 location of well penetrating salt.

PROPERTY LINE.

- SALT CONTOUR

- - SALT CONTOUR BENEATH OVERHANG

ROADS

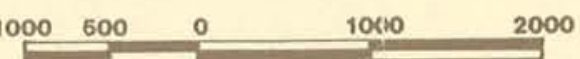

BIG HILL SALT DOME SITE DEVELOPMENT MAP (1) National 


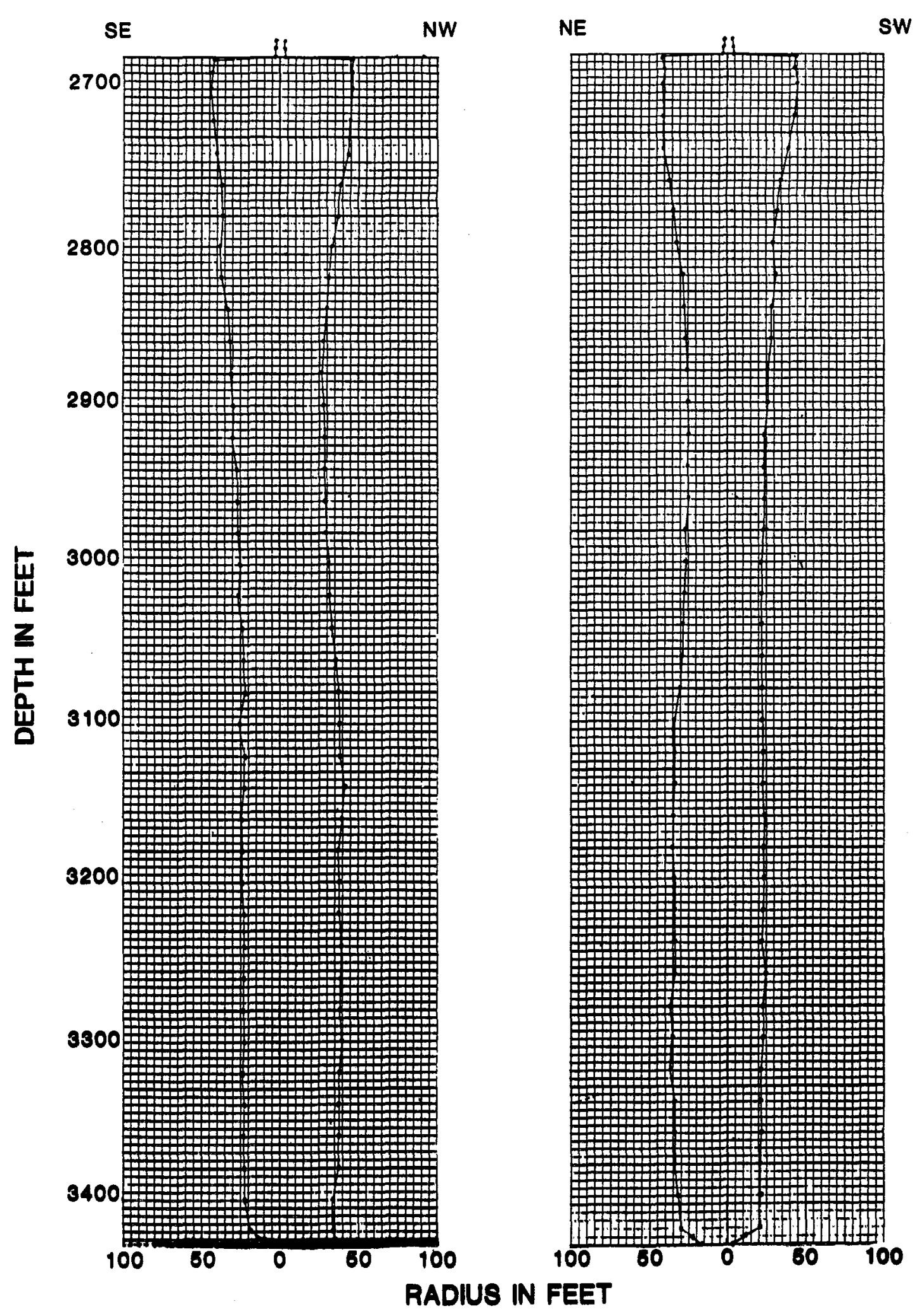

BIG HILL SALT DOME DOWELL SONAR SURVEY UNION OIL LPG \#1 1978 [1] Sarbonal

SEPT 1981 FIG. 2-2 


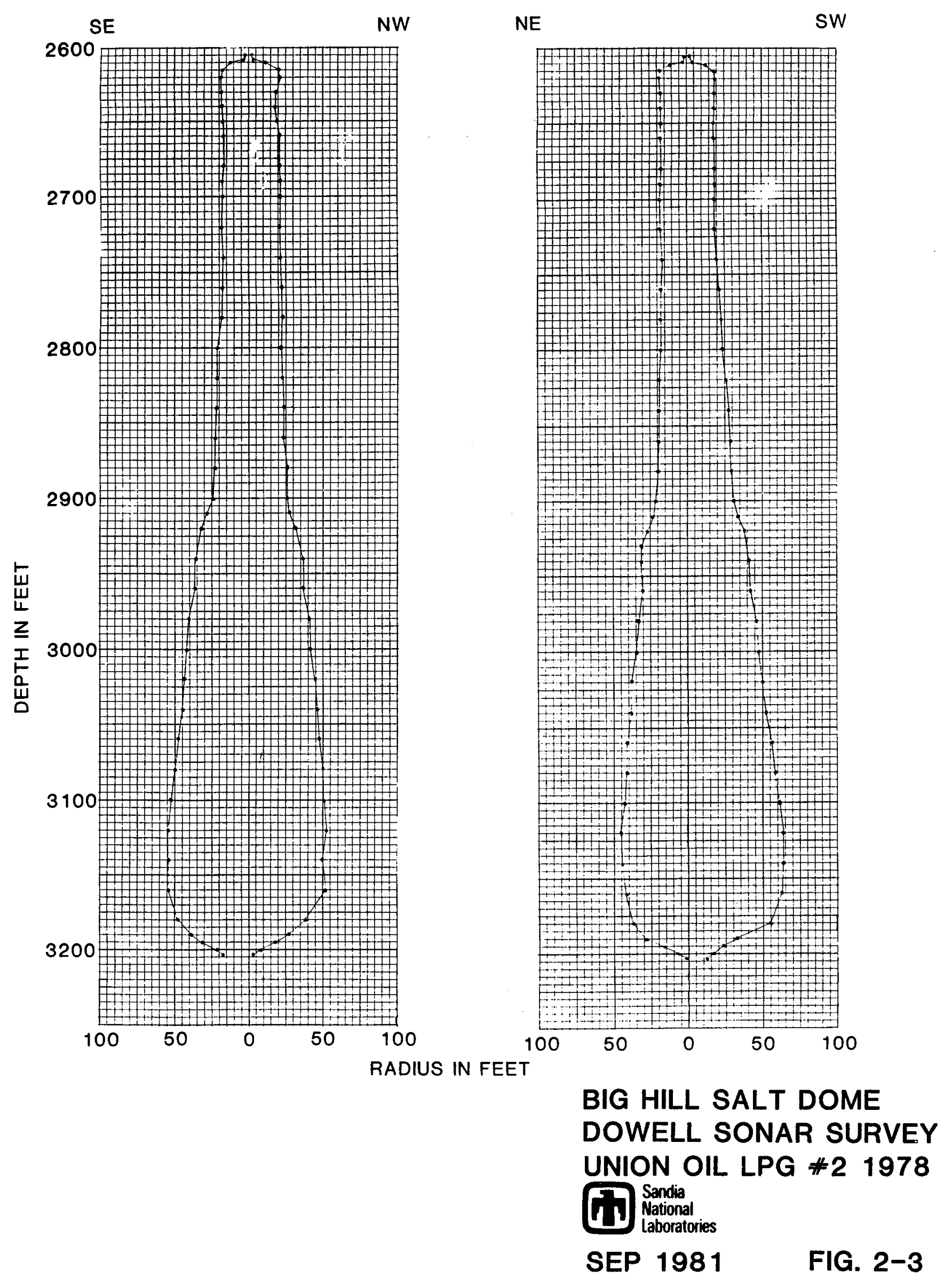


CHAPTER 3 - LOCAL GEOLOGY AND HYDROLOGY

Physiography

Big $\mathrm{Hill}$ is in southwestern Jefferson County $20 \mathrm{mi}$ southwest of Port Arthur, $70 \mathrm{mi}$ east of Houston, and $9 \mathrm{mi}$ north of the Gulf of Mexico. The site is $5.3 \mathrm{mi}$ north of the ICW and $1 \mathrm{mi}$ due north of Spindletop Marsh (Figure 3-1).

The site is in the West Gulf Coastal Plain Physiographic province, which is characterized by low, flat, featureless terrain. Marshes and meandering bayous are common. The plain dips toward the coast at $\sim 1-1 / 2 \mathrm{ft} / \mathrm{mi}$.

The surface expression of Big Hill salt dome is a roughly circular mound $\sim 7 \mathrm{mi}$ in diameter with a valley incised on the northwest edge (Figure 3-2). The maximum relief is $27 \mathrm{ft}$ above the surrounding sediments, which is $37 \mathrm{ft}$ above msl. Big Hill is covered by grass fields with some densely wooded areas.

Pimple mounds--sma11, circular mounds of sandy and silty materials--are common in the area surrounding the dome. Pimple mounds are 30 to $50 \mathrm{ft}$ in diameter and up to $1 \mathrm{ft}$ high. They seem to be soil-development features; however, their origin has never been satisfactorily determined.

\section{Geologic Setting}

Big $\mathrm{Hill}$ is located in the Gulf Coast Geosyncline, which is characterized by a thick accumulation of sediments. In vertical section, the geologic formations of the area form a series of gently dipping truncated wedges that thicken coastward, causing each wedge to din slightly steeper than the overlying wedge. The lithology reflects depositional environments including continental (alluvial plain), transitional (delta, lagoon, beach), and marine (continental shelf).

Salt domes within the geosyncline occur in two belts. One extends through northern Mississippi, Louisiana, and Texas; the other extends along the Gulf Coast and offshore. Big Hill is in the Southern Belt (Figure 3-3). Salt domes are a result of upward movement of deeply buried salt by means of plastic flow. This flow is initiated by the tremendous weight of the overlying sediments on the less-dense salt. Many salt domes, like Big Hill, have a surface expression; however, they are minor structural features of the region (Wood et a1, 1963). 
Geologic History

The relevant history of the site begins with the deposition of the thick sequence (1000 to $5000 \mathrm{ft}$ ) of post-Permian (Table 3-1) Louann (salt and anhydrite) evaporites in a desert basin much like today's Red Sea area. After deposition of the Louann evaporites, carbonates and eventually clastic sediments of late Jurassic and Cretaceous age (see Table 3-1) were deposited.

\section{Eocene}

The base of the Tertiary in this area is the Marine Midway Shale of Lower Eocene Age. The Laramide Orogeny in western North America during middle Eocene gave rise to the Rocky Mountains, which in turn supplied the clastic sediments of the Wilcox Formation in the Gulf basin. The basin, or geosyncline, has subsided in response to the deposition of sediments. The rate of subsidence almost equals the rate of deposition. The shallow beds dip toward the Gulf, with both dip and structural complexity increasing with depth. The formations represent alternating marine transgressions (thick marine shales) and regressions (thick marine shales) and regressions (deltaic sands with interbedded lagoonal or backswamp muds) resulting in very complex stratigraphy.

\section{1igocene}

There is no evidence from drilling to indicate the presence of the usual sheath of overpressured Vicksburg-Jackson shale around the salt, although it may be present on the south side below $4000 \mathrm{ft}$ and on the north side below $10,000 \mathrm{ft}$. However, the 1 imited production of $0 i 1$ close to the dome suggests that this sheath, which is a major source of oil, is also absent at depth.

01igocene deep-water shales are the oldest sediments penetrated by drilling near the dome. A regional structure map of the Anahuac Shale is included as Figure 3-4. The continuous shale sequence of clays and organicrich rocks is broken by the few thin sands of the underlying Frio Formation, deposited by submarine slides or turbidity currents flowing down the steep slope of the continental shelf from the north. The lower Frio (Hackberry sands) are the deep-gas pay sands of the Big Hill Northwest Field.

\section{Miocene}

The Miocene sediments consist of a pile of deltaic sands approximately $1 / 2$ mile thick with some individual sand units on the order of hundreds of feet thick.

The usual breakdown of the Miocene subsurface stratigraphy in Texas is a letter designation of deltaic sandgroups $A$ through $E$ that are separated by shales. The lowermost Planulina or $E$ sand overlies the top of the deepwater, overpressured shale sequence marked by the Discorbis (restricted) fauna (DR shale), which is the upper Anahuac Shale. Above the E sand is the Siphonina davisi (SD) shale, representing a marine transgression. The D sand, the main pay sand, is in turn separated from the C sands by the Robulus "L" (RL) shale, 
representing another marine transgression. The $C$ sand is the lowest sand aivove the deepwater shale. The Amphistigina "B" (AB) shale (marine transgression) overlies the $C$ sand. The Oakville, or $B$, sand overlies this shale. $A$ major mid-Miocene unconformity between the $B$ and $C$ sands marks the end of rapid sedimentation near the edge of the continental shelf. Above the $B$ sand is the Lagarto shale (Bigerina florida). The $A$ sand is a thin group of sands at the top of the Miocene.

Table 3-2 is a breakdown of the Miocene stratigraphy in and around the dome. The Miocene sands represent a typical delta regression sequence that is divisible into a number of distinct sand types based on mode of deposition. Each type has a typical orientation and extension so that, once its type is known, a particular sand can be mapped or predicted in lateral extent with great accuracy. In addition, at particular places in the deltaic sequence, the sand types can be identified or confirmed by permeability variations that are readily detectable on the electric logs.

The two main contrasting sand types are beach and channel sands. Figure 3-5, a sample log of a typical Miocene sequence, shows an interpretation of the sediment types.

These sands are in turn overlain by muds that are often highly organic. These lagoonal muds are succeeded by a relatively thin sequence of riverchannel sands that are gravely at the base and finer toward the top. These channel sands are highly permeable because of high-velocity sorting and cross-bedding of fluvial currents. Most channel sands were deposited inside meandering river beds as point bars. Thus these sands are formed into crescent-shaped deposits and are generally limited in extent.

\section{Pliocene}

Sediments of Pliocene age consist of silty clay with thin, lignitic sands that were deposited onshore in a backswamp area (Jones, et al, 1954). ilucin of the cap-rock material is of Pliocene age.

\section{Pleistocene}

Pleistocene sediments are related to recurring glacial advances and retreats (Table 3-1). Sea levels lowered during periods of glacial ice accumulation. As the glaciers melted, sea levels rose, resulting in the deposition of sands and gravels. Later in the interglacial periods the carrying capacity of the stream decreased as a result of decreased gradient. The glaciers melted and the sea level increased causing a decrease in the grain size of sediment to silt and clay (Bernard and LeBlanc, 1965).

The Lafayette Gravel marking the base of the glacial Pleistocene sediments includes some material of upper Pliocene age (Figure 3-6 and Table 3-3). The gravel is associated with the deep-stage erosion of the interior of the continent, and is 200 to $500 \mathrm{ft}$ thick. It is prominent on much of the Gulf Coast and lies unconformably over the Pliocene marine silts. This gravel forms the base of the Chicot aquifer and is in turn overlain by clays of Kansan and Nebraskan age (Tables 3-1 and 3-3). 
The Willis (Williana) Formation overlying the Lafayette gravel is of Nebraskan age. It is a sequence of sands, silts, and clay $\sim 300$ to $600 \mathrm{ft}$ thick in the Big Hill area.

The Lissie (Bentley) Sand is the most prominent bed in the lower Pleistocene section and is 100 to $600 \mathrm{ft}$ thick. It has a highly variable thickness typical of alluvial channel deposits during the glacial low stages of sea leve1. The sand was deposited at the beginning of the Yarmouth interglacial stage.

An unnamed clay of Yarmouthian age (Table 3-1), deposited as an interglacial backswamp sediment, overlies the Lissie Sand. Away from the dome, this unit lies at a depth of $\sim 700 \mathrm{ft}$. Over the dome, it was found to overlie the cap rock in some wells. The clay thickens to $>100 \mathrm{ft}$ away from the dome. It is likely that the limestone and gypsum cap rock has incorporated much of this unit.

The Montgomery Sand (Table 3-3, Figure 3-6) is a thick sequence (200 to $400 \mathrm{ft}$ ) of sands deposited by glacial meltwaters during the Sangamon interglacial stage. Sand and gravel with minor silt and clay were deposited by coalescing point bars as rivers meandered around the dome. Clayey or silty layers accumulated near the top of the Montgomery as the stream neared base level. At the site, these sands formed the edge of the Trinity River delta. This and the overlying sand are the major freshwater aquifers in southeastern Texas.

The Beaumont Clay was deposited over the Montgomery after the Sangamonian interglacial period. The formation is a backswamp deposit of clay and silt. The Beaumont forms the surface sediments at Big Hill and extends 200 to $300 \mathrm{ft}$ below the surface. It was partially oxidized and desiccated during a lowsealevel stage of the last ice age (Fisk, 1944). The clay is underlain in part by a variable or stray sand of Peorian age, often termed the Prairie Sand. Recent back-swamp marsh with sticky (bentonitic) black clay is $\sim \mathrm{ft}$ above mean low water (sea level).

\section{Regional Structure}

Faulting in the Gulf Coast region occurs on two scales: 1arge-scale regional faulting associated with basin filling, and small-scale localized faulting associated with the upward movement of salt domes. The regional faults can be mapped for miles and have displacements on the order of hundreds to thousands of feet.

The Gulf Coast geosyncline is typified by large-scale, east-west-trending normal faults (Figure 3-3). The faults are generally parallel to the present Gulf Coast or to one of the older Gulf Coast geosynclinal axes that are subparallel to the present coast. These faults are frequently referred to as "growth" faults since their origin was caused by the long-term, continuing subsidence of the geosynclinal basin. Gulf Coast growth faults are downthrown to the south in the direction of the major area of basin filling. The 
larger structures may have up to thousands of fault displacement. The faults dip at $\sim 60^{\circ}$ in the near-surface sediments but tend to flatten out at depth.

The local faulting associated with salt domes is restricted to the immediate dome area, seldom extending more than a few miles. Displacements of domal faults are normally on the order of tens to hundreds of feet, but can extend up to $1000 \mathrm{ft}$. Domal faulting at Big Hill is discussed in detail in Chapter 5.

\section{Soils}

The major soil groups present at Big Hill include the Hockley, Crowley, and the Morey silt loams (Crout, et al, 1960). The distribution of soils, which are all modifications of the Beaumont Clay, is shown in Figure 3-7.

The Hockley silt loam is typical over salt domes having a topographic expression. This soil covers most of the hill and is 14 to 30 in. thick. The upper horizon of this soil type is very pale brown and can hold a moderate amount of moisture for plants. The lower silt horizon absorbs water readily.

The Crowley silt loam (the Prairie Formation, in Louisiana) is present on the east side of tile site. The upper $12 \mathrm{in}$. is granular, but the subsoil is very compacted.

The Morey silt loam can hold a moderate amount of moisture for plant use, but common surface crusts and impermeable subsoil make it difficult for water to enter the soil. The surface is a silt loam in most places, but clay loam or very fine sandy loam with yellowish-brown mottles is also present. The subsoil is ol ive gray with red and yellow-brown mottles. Large concretions of calcium carbonate are common in the lower subsoil.

The unmodified Beaumont marine clay is present in the extreme southwest and northeast corners of Big Hill. The soil is a dark-gray silty clay loam, or clay. The subsoil is mottled with brown by partial oxidation.

0 il wasteland occurs in the southern portion of Big Hill and to a lesser extent at former drilling sites.

As part of the conceptual design study, PB/KBB (1979) took several soil borings and tested samples. In general, the soil profile at Big Hill consists of a surface layer 1 to $3 \mathrm{ft}$ thick composed of silt and fine sand underlain by medium stiff to stiff clays of varying composition interbedded with silty fine sand extending to the depth of the boring, $100 \mathrm{ft}$. Locally a silty sand layer $<5 \mathrm{ft}$ thick exists at depths of 8 to $10 \mathrm{ft}$ below the surface.

The shear strength of cohesive soils ranges from 700 to $13001 \mathrm{~b} / \mathrm{ft}^{2}$ for the first $10 \mathrm{ft}$ f the soil profile. From 10 to $25 \mathrm{ft}$ the value ranges from 450 to $700 \mathrm{lb} / \mathrm{ft}^{2}$. Samples collected from this interval have slickenside surfaces on which the soil could have failed. Below $25 \mathrm{ft}$, the shear strength increases to 1000 to $2000 / 1 \mathrm{~b} / \mathrm{ft}^{2}$. 
Results of consolidation tests indicate that clays are generally overconsolidated and of low compressibility. The natural moisture contents of all soils are lower than the liquid limits.

Swelling clays are common in the Beaumont clay and associated soils. Soils that may swell are those subject to seasonal moisture change and that have an overburden pressure less than the swelling pressure of the soil. The local depth of seasonal moisture change is $8 \mathrm{ft}$ below the surface. The plasticity index of soil in the upper $10 \mathrm{ft}$ varied from 20 to 50 , indicating soils of medium to high swelling potential. However, swel1-pressure tests of two samples resulted in swell pressures of 66 to 233 psf. A swell pressure $<400$ psf indicates low swelling potential. Swe11-potential tests of two samples resulted in volume changes of $1.5 \%$ and $2.8 \%$. A volume change of $1.5 \%$ to $5 \%$ indicates a medium swelling potential. In general, $P B / K B B$ concluded that, based on the lab tests, these soils show a low potential for swelling. An overburden of only 2 to $3 \mathrm{ft}$ would be enough to restrain swel1induced displacements.

A complete description of the soil profiles, the testing procedures, and results can be found in $\mathrm{PB} / \mathrm{KBB}$ (1979). This report also includes information on soils at the ICW water source location.

\section{Hydrology}

The surface water system is shown in Figures 3-8 and 3-2. There are two brine ponds on the Union $0 i 1$ Company property, one with a capacity of 320,000 bbl, the other $380,000 \mathrm{bbl}$. Two freshwater ponds are also located close to the site. One pond, on the north side of the dome, covers 50 acres; it has been modified somewhat for rice field irrigation. The other pond to the southeast covers 20 acres. It appears to have been built up on the south side. The freshwater ponds do not seem to be related to subsidence. Surface drainage is good, and erosion is negligible because of permanent ground cover. A discussion of the regional water system is presented in DOE (1978).

Water for leaching the SPR caverns (up to 1,400,000 bbl/day) will be taken from the ICW south of the site (PB/KBB, 1979). This segment of the waterway extends from the Sabine-Neches Canal southwest along the Gulf Coast toward Galveston. It is $250 \mathrm{ft}$ wide with a maintained depth of $12 \mathrm{ft}$. Flow is influenced by winds and tides but is generally to the northeast. Spindletop Ditch joins the ICW about 5-1/2 mi southeast of the Big Hill dome. The ditch is $150 \mathrm{ft}$ wide with a depth of $<6 \mathrm{ft}$. Water quality data and sediment quality data for the ICW south of the dome are included in DOE (1978).

The subsurface hydrologic units of the Big $\mathrm{Hill}$ area are the Chicot and Evangeline Aquifers and the Burkeville Aquiclude. The units are composed of gravel, sand, silt, and clay of Miocene, Pliocene, and Pleistocene age (Table 3-3). Hydrologic cross sections through the dome are shown in Figures 3-9 and 3-10. 
The southwest-northeast hydrologic section (Figure 3-9) shows the convergence and pinchout of Pliocene and lower Pleistocene sands. The later Montgomery formation thickens slightly to form the permeable fresh and slightly saline water zones over the cap rock.

The Burkeville Aquiclude is the lowermost hydrologic unit and corresponds to the Miocene Lagarto Clay (Table 3-3).

The Evangeline Aquifer overlies the Burkeville Aquiclude and includes the lower Pliocene Goliad Sand and the silts and sands of the upper Pliocene (Table 3-3). The total thickness of the aquifer is 1000 to $1100 \mathrm{ft}$ near the dome. The Evangeline Aquifer contains saline water in the Big Hill area.

The Chicot Aquifer overlies the Evangel ine Aquifer and consists of the Pleistocene Lafayette Gravel, Will is Sand, Bentley Formation, Montgomery Formation, and the Praire Formation, (Beaumont Clay) (Table 3-3). Water in the upper Chicot is fresh but grades to saline at depth. The total thickness of the aquifer is 1250 to $1350 \mathrm{ft}$. The chicot is more permeable than the Evangeline and differs in grain size, cementation, and compaction.

The Chicot can be divided into an upper unit that may correspond to the 200-ft sand in southwestern Louisiana, and a lower unit that may correspond to the 500 and 700-ft sands. In some places the two units are separated by clay. However, determination of the boundary is especially difficult around salt domes. Interconnection of aquifers is indicated by electric logs and water quality data near Big Hill (Wesselman and Aronow, 1973).

While boring for soil profile determinations, PB/KBB (1979) noted that the groundwater surface varied from a depth of $\sim 6 \mathrm{ft}$ below the surface near the center of the hill (elevation $+37 \mathrm{ft} \mathrm{msl)} \mathrm{to} \mathrm{about} \mathrm{ground} \mathrm{level} \mathrm{near} \mathrm{the}$ base of Big Hill (10 ft msl). The groundwater level generally follows the topography of the site.

Fresh water $(<1000 \mathrm{mg} / \mathrm{L}$ dissolved solids) is limited to the Upper Chicot in the Big Hill area. Over the dome, fresh water is limited to the zone extending from near the surface to a depth of slightly less than $-100 \mathrm{ft}$ msl (Figures 3-9 and 3-10). Less than $2 \mathrm{mi}$ northwest of the dome, fresh water extends to $-200 \mathrm{ft} \mathrm{msl}$. Slightly saline $(1000$ to $3000 \mathrm{mg} / \mathrm{L}$ dissolved solids) water is present below the fresh water to $-300 \mathrm{ft}$ msl over the dome (Figures 3-9 and 3-10) and to $-500 \mathrm{ft} \mathrm{ms} l$ near Winnie (Figure 3-11). Saline water is probably introduced into the shallower sands by dissolution of the salt dome or from vertical movement of deeper saline water around the flanks of the dome (Wesselman and Aronow, 1973).

Major centers of groundwater withdrawal from the Lower Chicot are at Baytown, $40 \mathrm{mi}$ west of Big $\mathrm{Hill}$ and in the Beaumont/Port Arthur area, $22 \mathrm{mi}$ northeast of the site. The decline in water at Beaumont/Port Arthur affects water levels at Big Hill and produces a movement of groundwater southeast to eastward from Big Hil1 (Wesselman and Aronow, 1973). 
The major center for groundwater withdrawal in the Upper Chicot is at Winnie, $8 \mathrm{mi}$ northwest of Big Hill. Withdrawals at Winnie have two major results. First, the saline/freshwater interface in the Upper Chicot is drawn northwest toward Winnie. Second, the reduction in aquifer pressure may cause some minor regional subsidence. From 1951 to 1965, the water level had declined a few feet at Big Hill (Table 3-4).

Table 3-5 summarizes the aquifer tests in the Big Hill area. Table 3-6 gives the accompanying chemical analyses of the water wells in the area. 
Table 3-1

Geologic Timetable

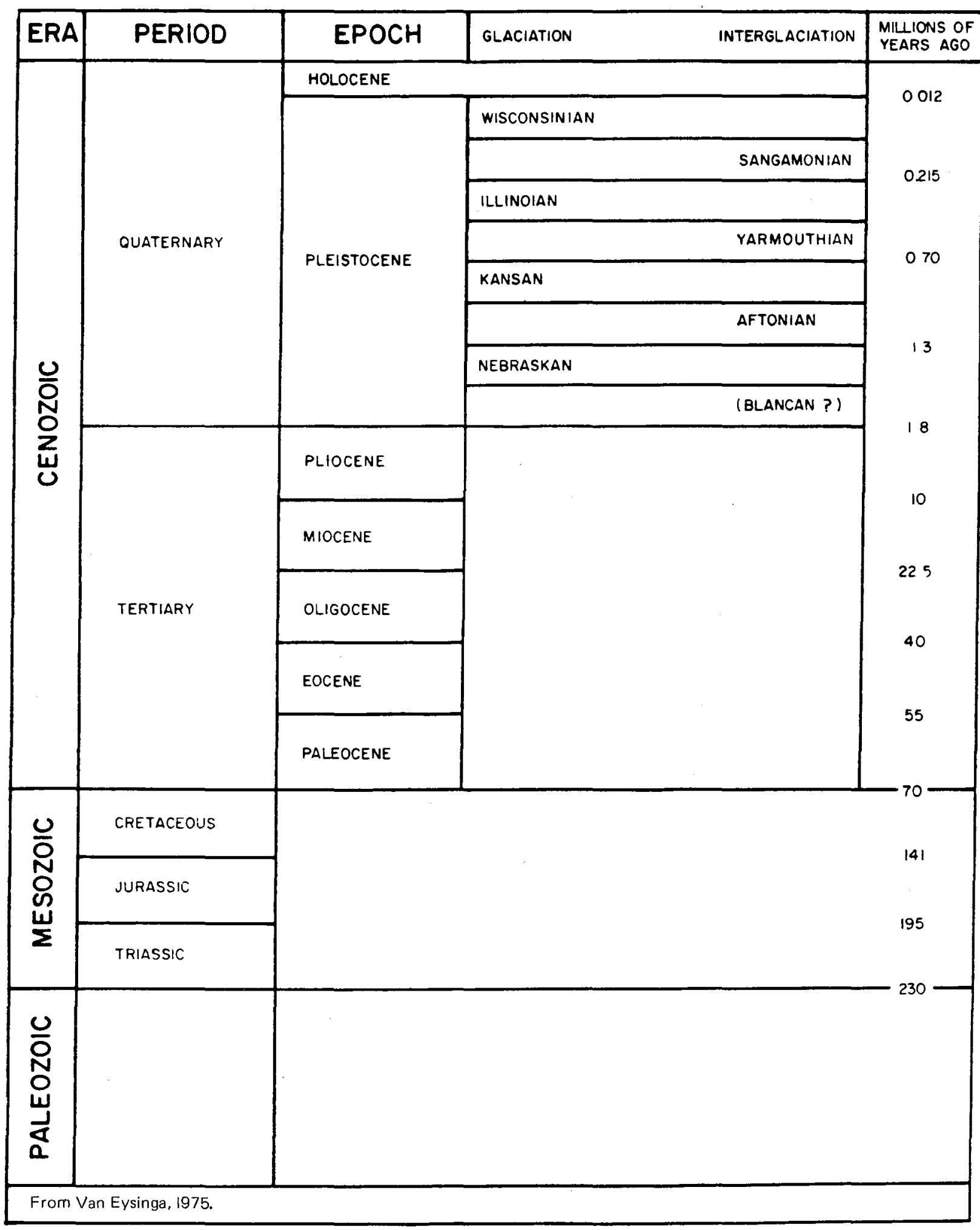


Table 3-2

Big Hill SPR Site Tertiary Geologic Units

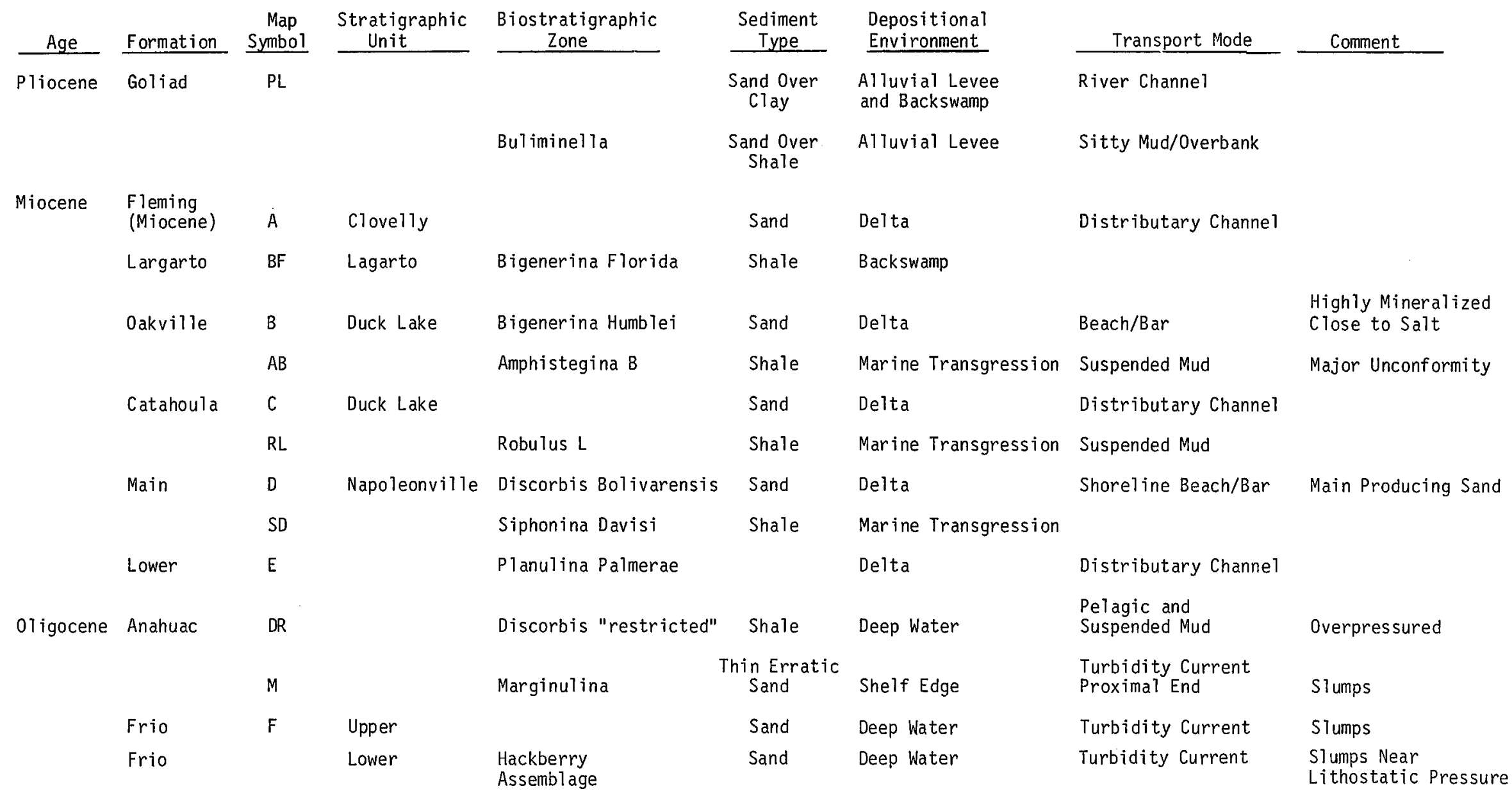


Table 3-3

Big Hi11 SPR Site Hydrologic Units

\begin{tabular}{|c|c|c|c|}
\hline SYSTEM & SERIES & FORMATION & $\begin{array}{c}\text { HYDROLOGIC } \\
\text { UNIT } \\
\end{array}$ \\
\hline \multirow{5}{*}{ Quaternary } & \multirow{5}{*}{ Pleistocene } & Beaumont Clay & $\begin{array}{c}\text { Upper Chicot } \\
\text { Aquifer }\end{array}$ \\
\hline & & Montgomery Sand & \multirow{4}{*}{$\begin{array}{c}\text { Lower Chicot } \\
\text { Aquifer }\end{array}$} \\
\hline & & Lissie Sand & \\
\hline & & Will is Formation & \\
\hline & & Lafayette Gravel & \\
\hline \multirow[b]{2}{*}{ Tertiary } & Pliocene & Goliad Sand & $\begin{array}{l}\text { Evangeline } \\
\text { Aquifer }\end{array}$ \\
\hline & Miocene & Fleming Formation & $\begin{array}{l}\text { Burkeville } \\
\text { Aquiclude }\end{array}$ \\
\hline
\end{tabular}




\section{Table 3-4}

Water Levels in Wells at

Big Hi11, 1951-1965

We11 PT-64-22-301

Owner: Pipkin Ranch

Elevation: 5
We11 PT-64-23-103

Owner: Pipkin Ranch

Elevation: 5

\begin{tabular}{lrr}
\multicolumn{2}{c}{ Date } & $\begin{array}{r}\text { Water } \\
\text { Level }\end{array}$ \\
\hline May & 17,1951 & 0.67 \\
June & 5,1952 & 2.47 \\
May & 22,1953 & 6.16 \\
May & 28,1954 & 9.99 \\
December & 14,1955 & 8.91 \\
May & 16,1956 & 7.74 \\
May & 29,1957 & 9.80 \\
May & 21,1958 & 9.42 \\
October & 19,1959 & 7.72 \\
October & 11,1960 & 14.64 \\
March & 20,1963 & 10.48 \\
May & 7,1965 & 9.73
\end{tabular}

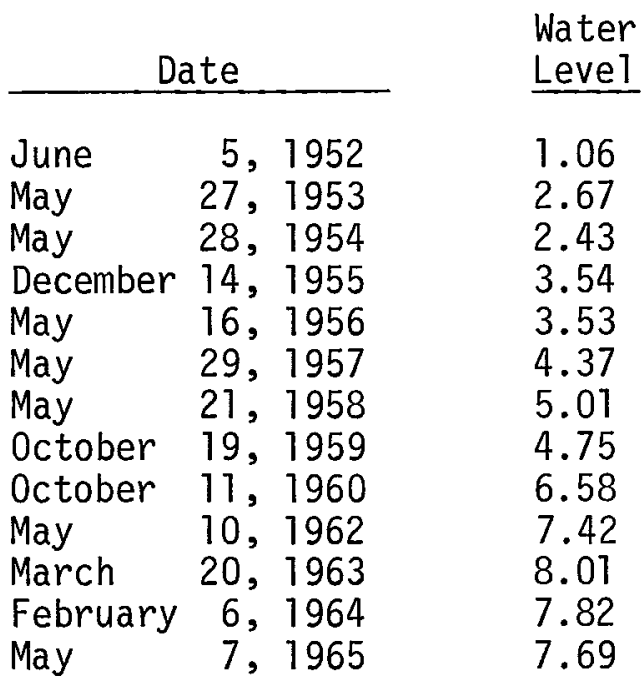

$\overline{\star F r o m ~ W e s s e l m a n ~ a n d ~ A r o n o w, ~} 1973$. 
Table 3-5

Summary of Aquifer Tests, Upper Chicot

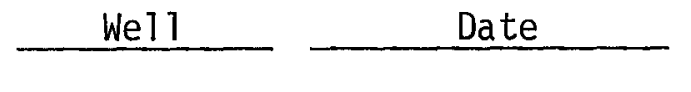

PT-64-15-704 September 22, 1966

PT-64-15-705
Coefficient of
Transmissibility
(GPD/ft)

21,300

21,600
Coefficient of
Permeability
$\left(\mathrm{GPD} / \mathrm{ft}^{2}\right)$

207

216
Specific

Capacity

(GPM/ft

Coefficient

of Storage

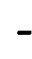

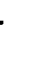

$-$ of Drawdown)

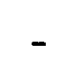

1.7
Remarks

Recovery

observation well

Recovery pumped well; 23-h test

\footnotetext{
ॠFrom Wesselman and Aronow, 1973.
} 
Chemical Analyses of Water*

\begin{tabular}{|c|c|c|c|c|c|c|c|c|c|c|c|c|c|c|c|c|c|}
\hline Well & $\begin{array}{l}\text { Depth of } \\
\text { Producing } \\
\text { Interval } \\
(\mathrm{ft}) \\
\end{array}$ & $\begin{array}{l}\text { Date of } \\
\text { Collection }\end{array}$ & $\begin{array}{l}\text { Silica } \\
\left(\mathrm{SiO}_{2}\right) \\
\end{array}$ & $\begin{array}{l}\text { Iron } \\
(\mathrm{Fe})\end{array}$ & $\begin{array}{l}\text { Carcium } \\
\text { (Ca) }\end{array}$ & $\begin{array}{l}\text { Magne- } \\
\text { sium } \\
\text { (mg) }\end{array}$ & $\begin{array}{c}\text { Sodium } \\
\text { (Na) }\end{array}$ & $\begin{array}{l}\text { Potas- } \\
\text { sium } \\
\text { (K) }\end{array}$ & $\begin{array}{l}\text { Bicar- } \\
\text { bonate } \\
\left(\mathrm{HCO}_{3}\right) \\
\end{array}$ & $\begin{array}{l}\text { Sul- } \\
\text { fate } \\
\left(\mathrm{SO}_{4}\right) \\
\end{array}$ & $\begin{array}{c}\text { Chloride } \\
\text { (C1) }\end{array}$ & $\begin{array}{l}\text { Fluo- } \\
\text { ride } \\
\text { (F) } \\
\end{array}$ & $\begin{array}{c}\text { Nitrate } \\
\text { (NO) }\end{array}$ & $\begin{array}{c}\text { Dis- } \\
\text { solved } \\
\text { Solids } \\
\end{array}$ & $\begin{array}{l}\text { Hard- } \\
\text { ness } \\
\text { as } \\
\mathrm{CaCO}_{3} \\
\end{array}$ & $\begin{array}{c}\text { Specific } \\
\text { Conductance } \\
(\mu \mathrm{mho} \text { at } \\
\left.25^{\circ} \mathrm{C}\right) \\
\end{array}$ & $\mathrm{pH}$ \\
\hline 901 & 162 & $1-28-42$ & - & - & 50 & 15 & 503 & - & 665 & 2 & 518 & - & 1.0 & 1,416 & 184 & - & - \\
\hline 902 & 200 & $8-26-41$ & - & - & +5 & 18 & 348 & - & 427 & 2 & 340 & - & 20 & 923 & 74 & - & - \\
\hline Pure 2 & $170-191$ & $7-17-56$ & 52 & 20 & 1170 & 330 & $5300^{*}$ & - & 300 & 2420 & 9250 & - & - & 18,850 & 4300 & 26,400 & 7.9 \\
\hline Pure 2 & $291-307$ & $7-19-56$ & 145 & 1.1 & 1350 & 310 & $6880^{*}$ & - & 253 & 2390 & 12,000 & - & - & 23,350 & 4650 & 28,240 & 7.9 \\
\hline $\begin{array}{l}\text { Pure } 3 \\
(705)\end{array}$ & $315-330$ & $7-26-56$ & 22 & 0.34 & 21 & 11 & $456^{*}$ & - & 622 & 3 & 380 & - & - & 1,550 & 98 & 11,650 & 7.62 \\
\hline $\begin{array}{l}\text { Pure } 3 \\
(705)\end{array}$ & $392-406$ & $7-24-56$ & 17 & 2.15 & 250 & 104 & $2183^{*}$ & - & 478 & 587 & 3,400 & - & - & 7,030 & 1050 & 2,135 & 8.62 \\
\hline $\begin{array}{l}\text { Pure } 3 \\
(705)\end{array}$ & 415 & $9-23-66$ & 18 & 0.04 & 72 & 26 & 782 & 6.9 & 660 & 96 & 980 & 0.4 & 1.5 & 2,370 & 286 & 4,090 & 7.3 \\
\hline 301 & 327 & $8-26-41$ & - & - & 18 & 11 & 417 & - & 622 & 2 & 345 & - & 20 & 1,099 & 92 & - & - \\
\hline 101 & 327 & $8-26-41$ & - & - & 18 & 11 & 494 & - & 653 & 2 & 445 & 0.4 & 20 & 1,297 & 92 & - & - \\
\hline 103 & 250 & $8-26-41$ & - & - & 28 & 17 & 568 & - & 695 & 2 & 570 & - & 20 & 1,527 & 141 & - & - \\
\hline 104 & 250 & $8-26-41$ & - & - & 38 & 17 & 624 & - & 702 & 2 & 670 & 0.3 & 20 & 1,696 & 166 & - & - \\
\hline 201 & 178 & $8-26-41$ & - & - & 61 & 39 & 934 & - & 659 & 2 & 1,280 & - & 20 & 2,640 & 314 & - & - \\
\hline
\end{tabular}

${ }^{\star} \mathrm{Na}+\mathrm{K}$

(Anatyses given are in $\mathrm{mg} / \mathrm{L}$ except SAR, RSC, specific conductance, and $\mathrm{pH}$

\section{Pure 2 170-191}

Free Carbon Dioxide $\mathrm{CO}_{2}-5 \mathrm{ppm}$

Total Sulfide, S, $25 \mathrm{ppm}$

Noted sulphur odor and salty taste

\section{Pure $4 \quad 315-330$}

\section{No odor}

Free Carbon Dioxide, $\mathrm{CO}_{2}-0$

Total Sulfide, S-ND

From Wesselman and Aronow, 1973.

\section{Pure 2 291-307}

Free Carbon Dioxide, $\mathrm{CO}_{2}-4 \mathrm{ppm}$ Total Sulfide, S, $-10 \mathrm{ppm}$

Noted sulphur odor and salty taste

Pure $3 \quad 392-406$

Slight sulphur odor

Free Carbon Dioxide, $\mathrm{CO}_{2}-17$ ppm

Total Sulfide, $S-0$ ppm 


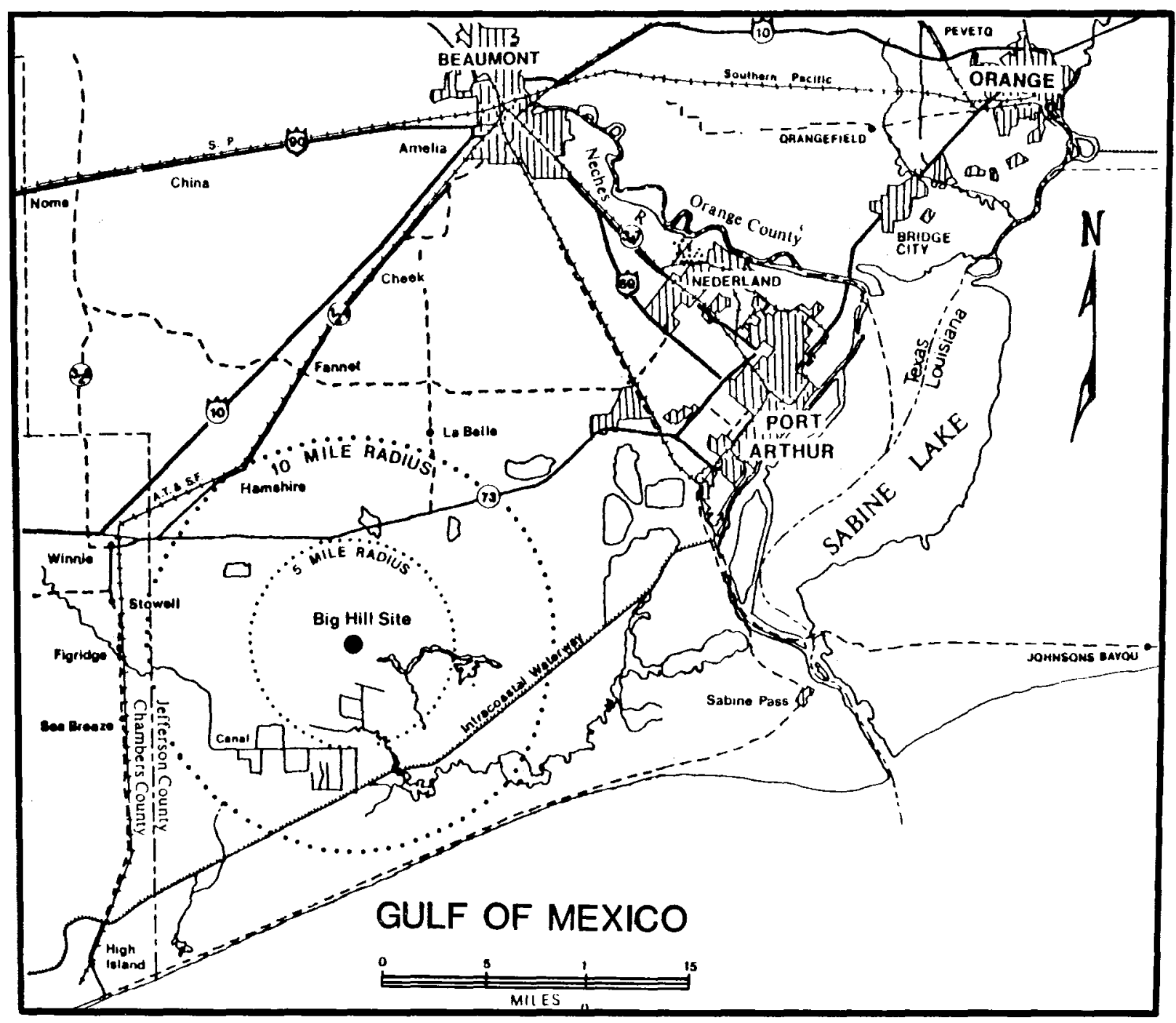

FROM DOE, 1978.

BIG HILL SALT DOME SITE LOCATION MAP 


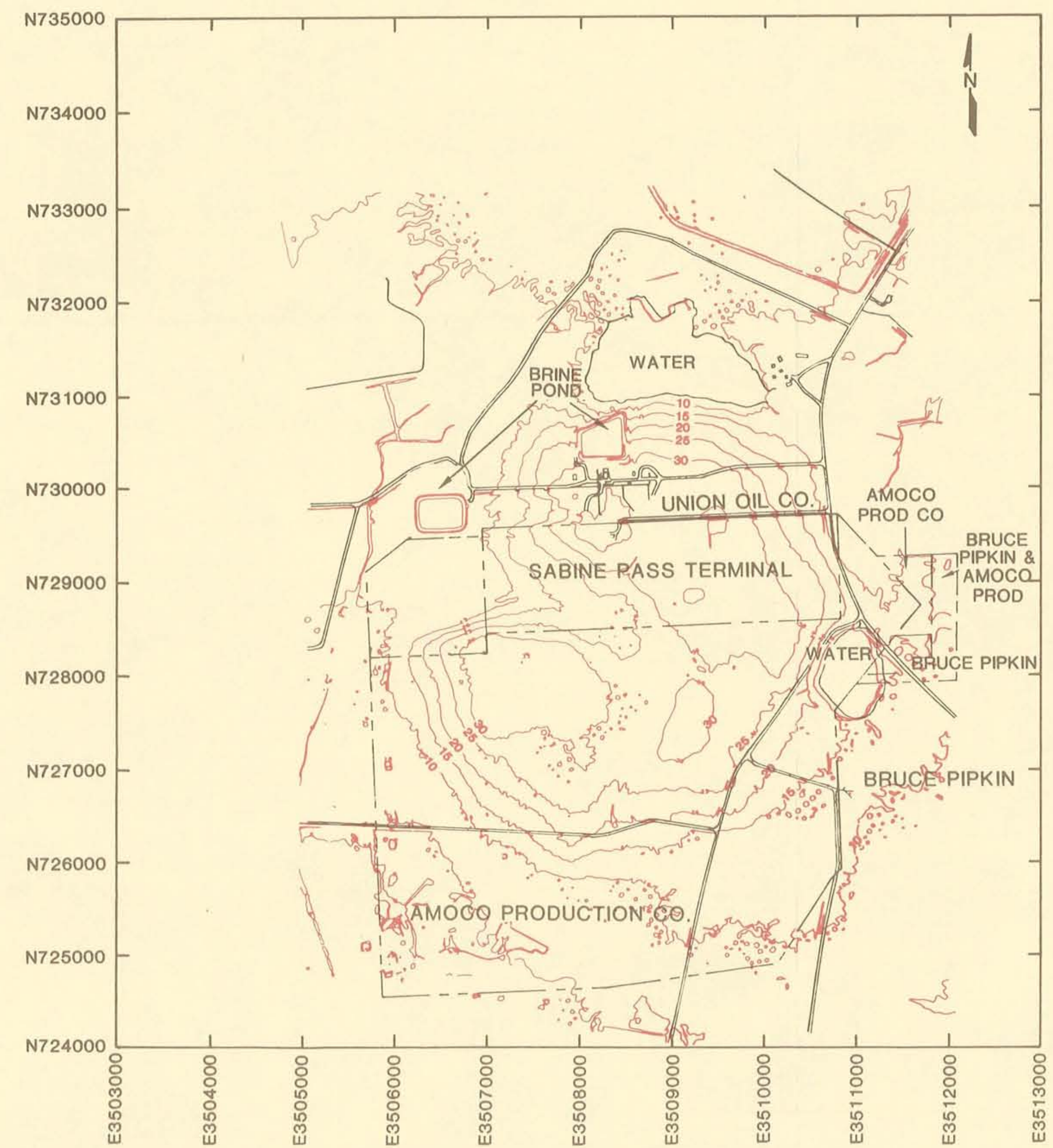

LEGEND

- - PROPERTY LINE

ROAD

5 FOOT TOPOGRAPHIC CONTOURS

$1000800 \quad 0$

$1000 \quad 2000$

WISTANCE IN FEE

BIG HILL SALT DOME TOPOGRAPHIC MAP Ii Tandianal

SEP 1981 FIG. 3-2 


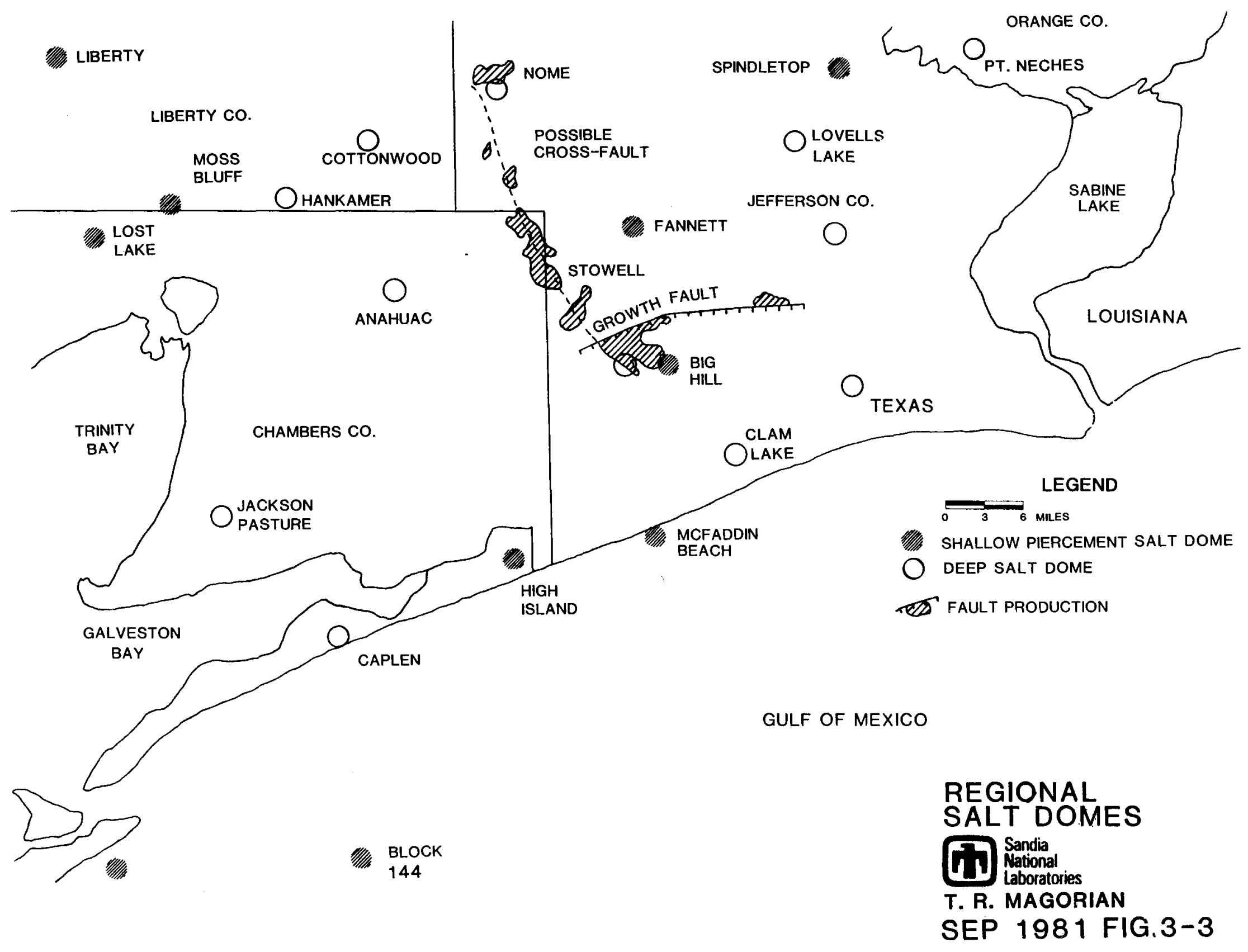




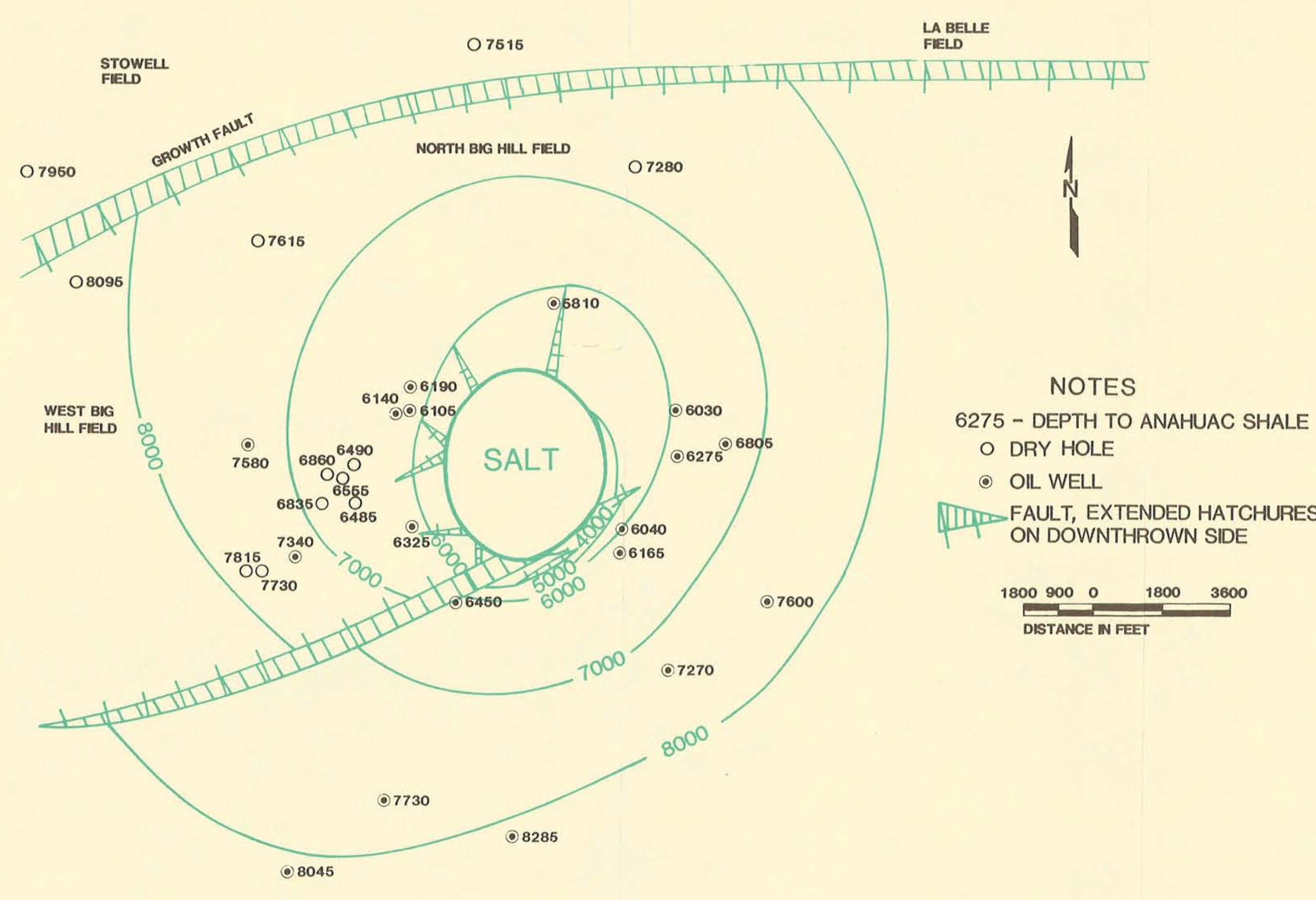

BIG HILL SALT DOME REGIONAL STRUCTURE ANAHUAC SHALE (11) Sandianal

T. R. MAGORIAN SEP 1981 FIG. 3-4 
JAYRED

FITZHUGH $* 9$
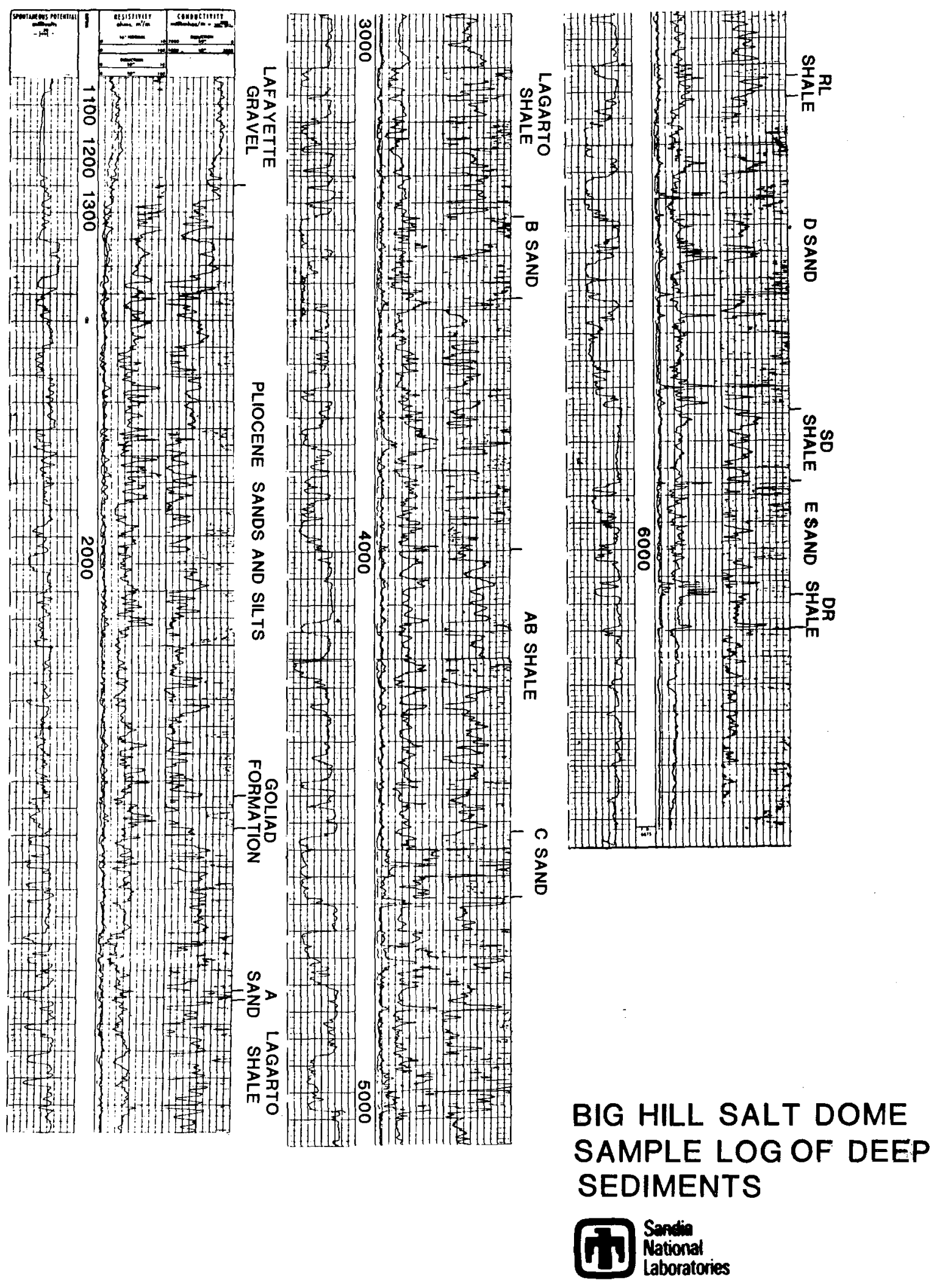

T.R. MAGORIAN

SEP 1981 FIG. 3-5 


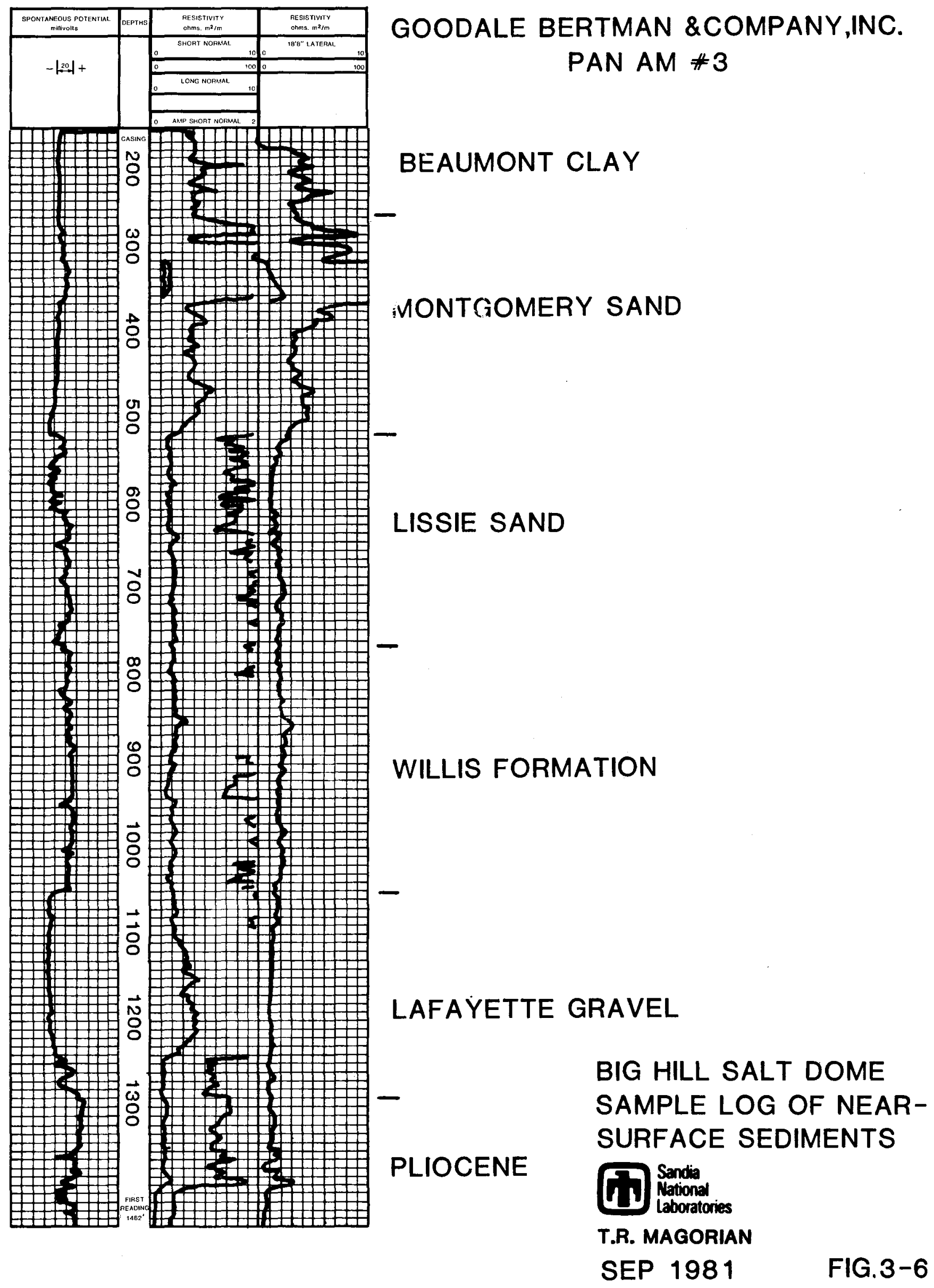




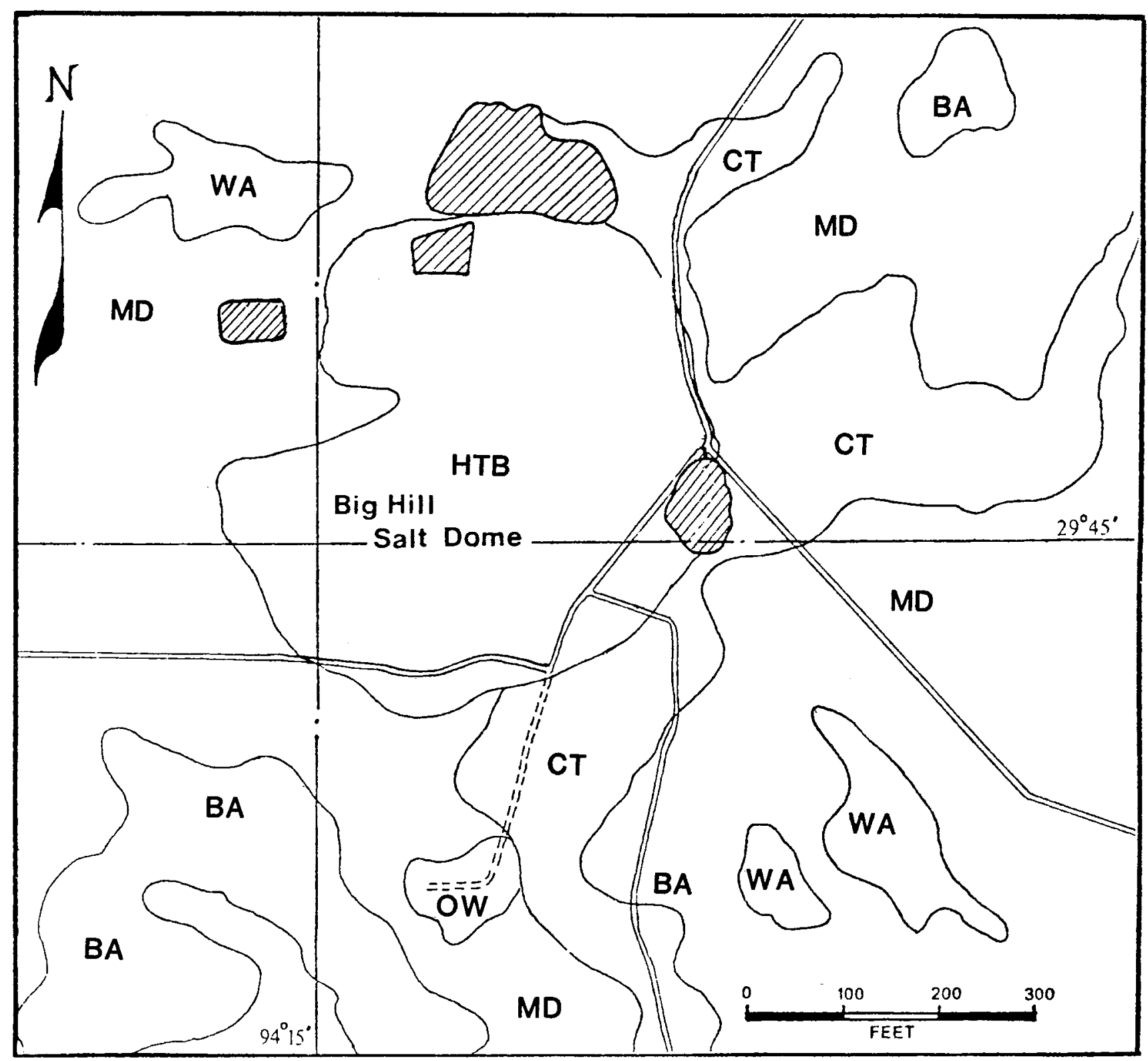

HTB HOCKEY SILT LOAM BA BEAUMONT CLAY MD MOREY SILT LOAM OW OIL WASTE LAND CT CROWLEY SILT LOAM WA WALLER SOILS VIIID WATER

FROM CROUT, et al, 1965.

BIG HILL SALT DOME SOIL DISTRIBUTION MAP 


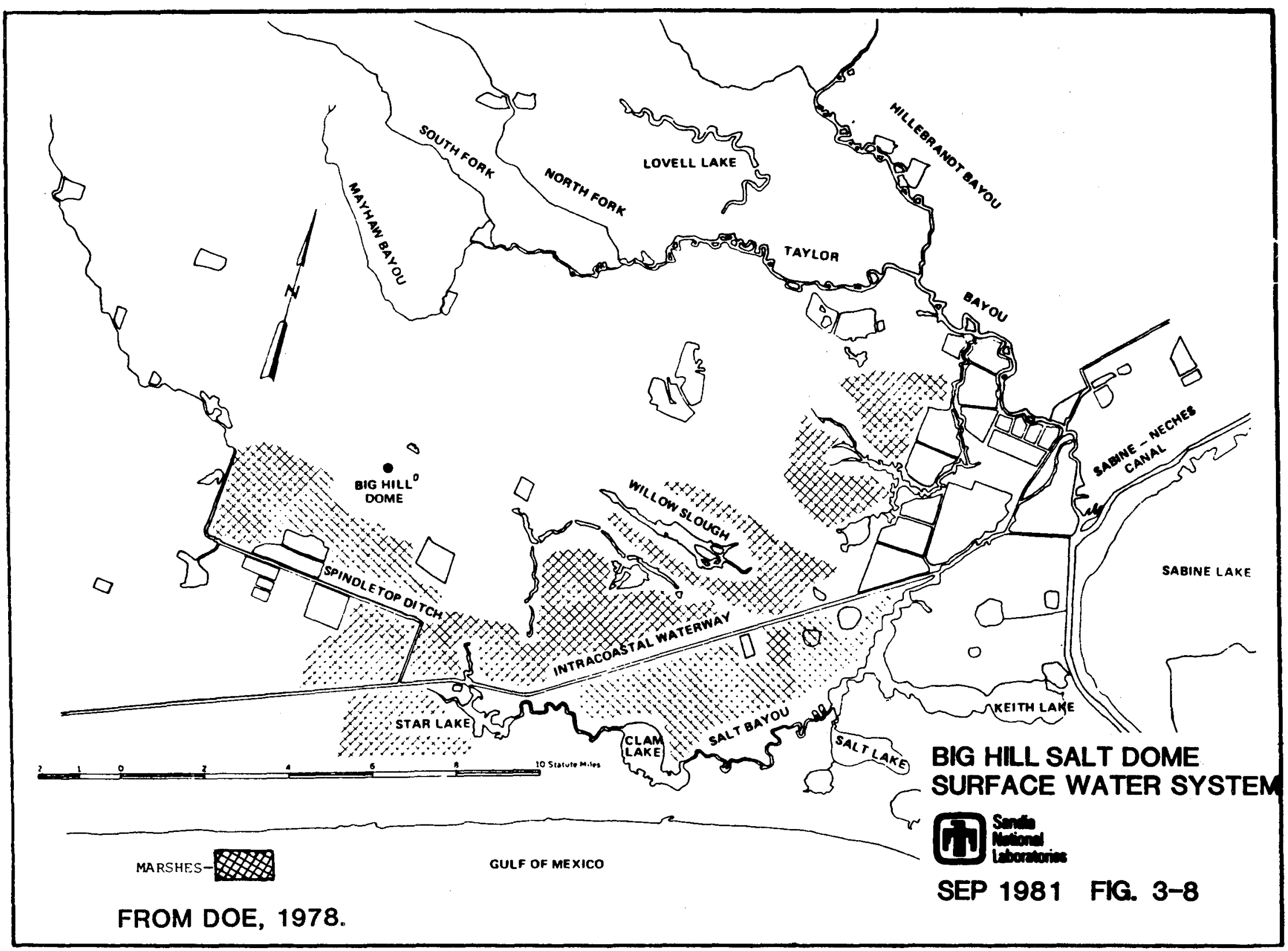




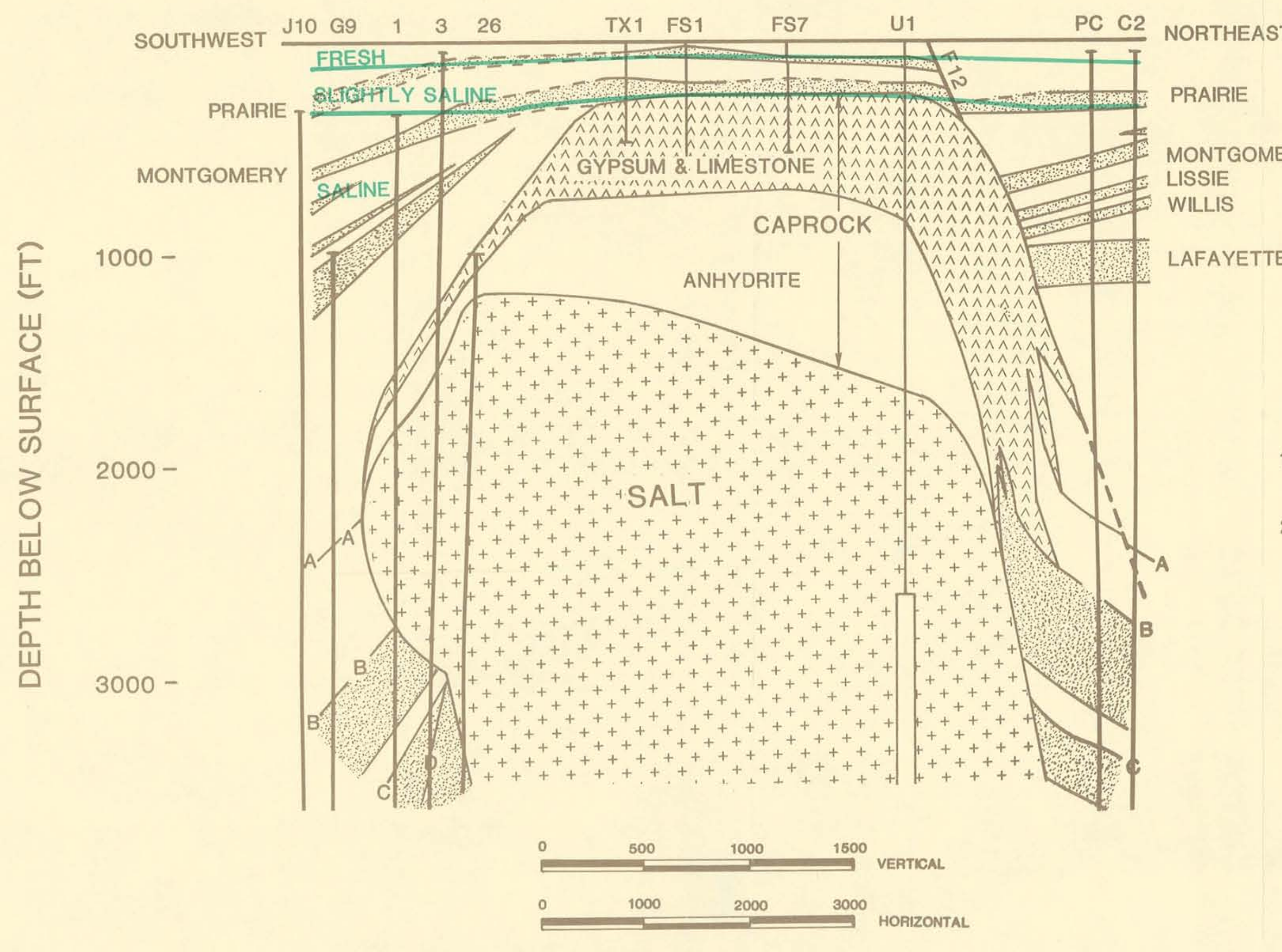

\section{NOTES}

1. SEE FIGURE 5-2 FOR SECTION LINE

2. T - INDICATES LOGGED INTERVAL
BIG HILL SALT DOME

SOUTHWEST-NORTHEAST

HYDROLOGIC CROSS SECTION

\section{Ii. Nandianal}

T. R. MAGORIAN

SEP 1981

FIG.3-9 


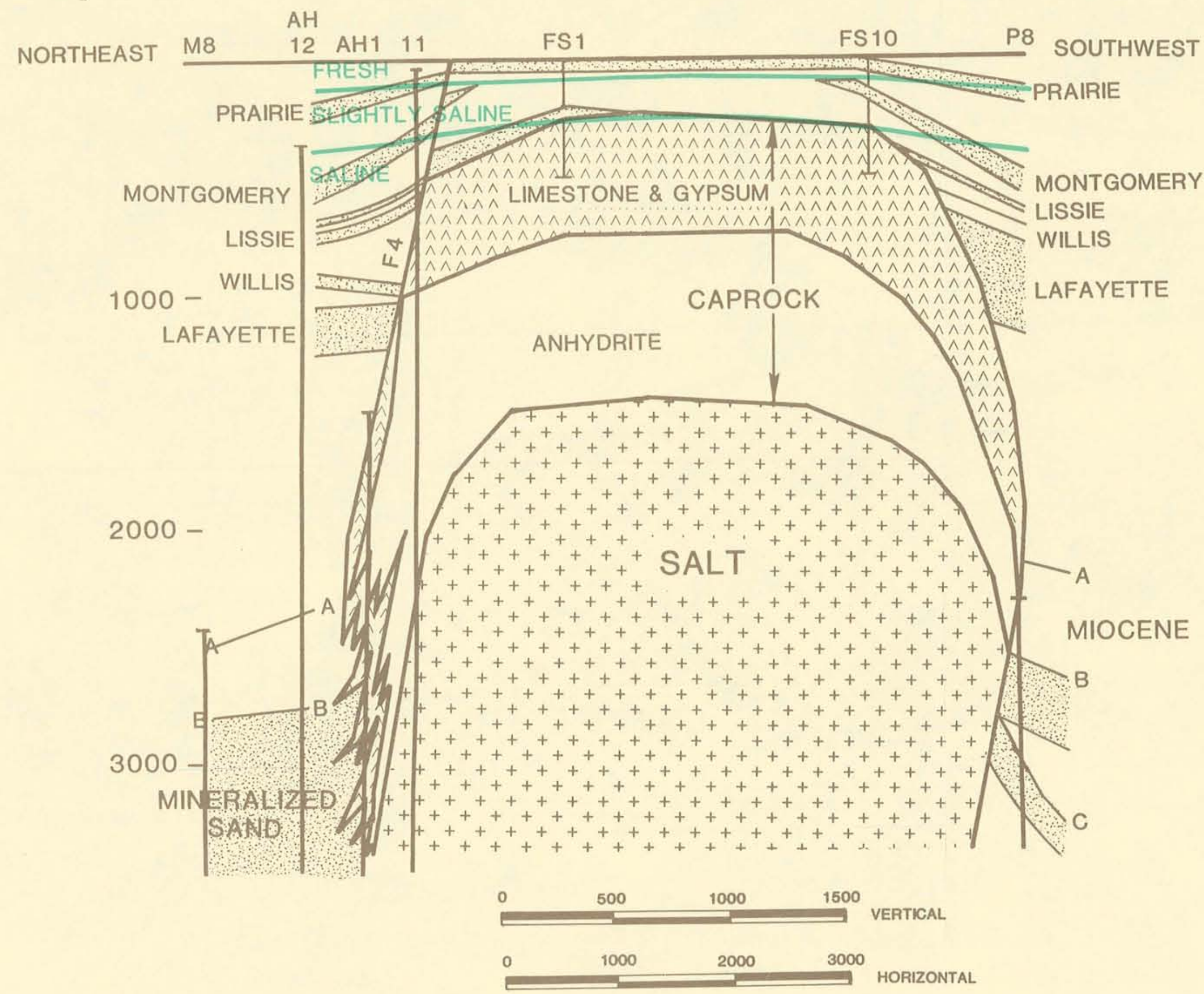

\section{NOTES \\ 1. SEE FIGURE 5-2 FOR SECTION LINE \\ 2. T - INDICATES LOGGED INTERVAL}

BIG HILL SALT DOME NORTHWEST-SOUTHEAST HYDROLOGIC CROSS SECTION

\section{Nantional}

T. R. MAGORIAN

SEP 1981

FIG. $3-10$ 


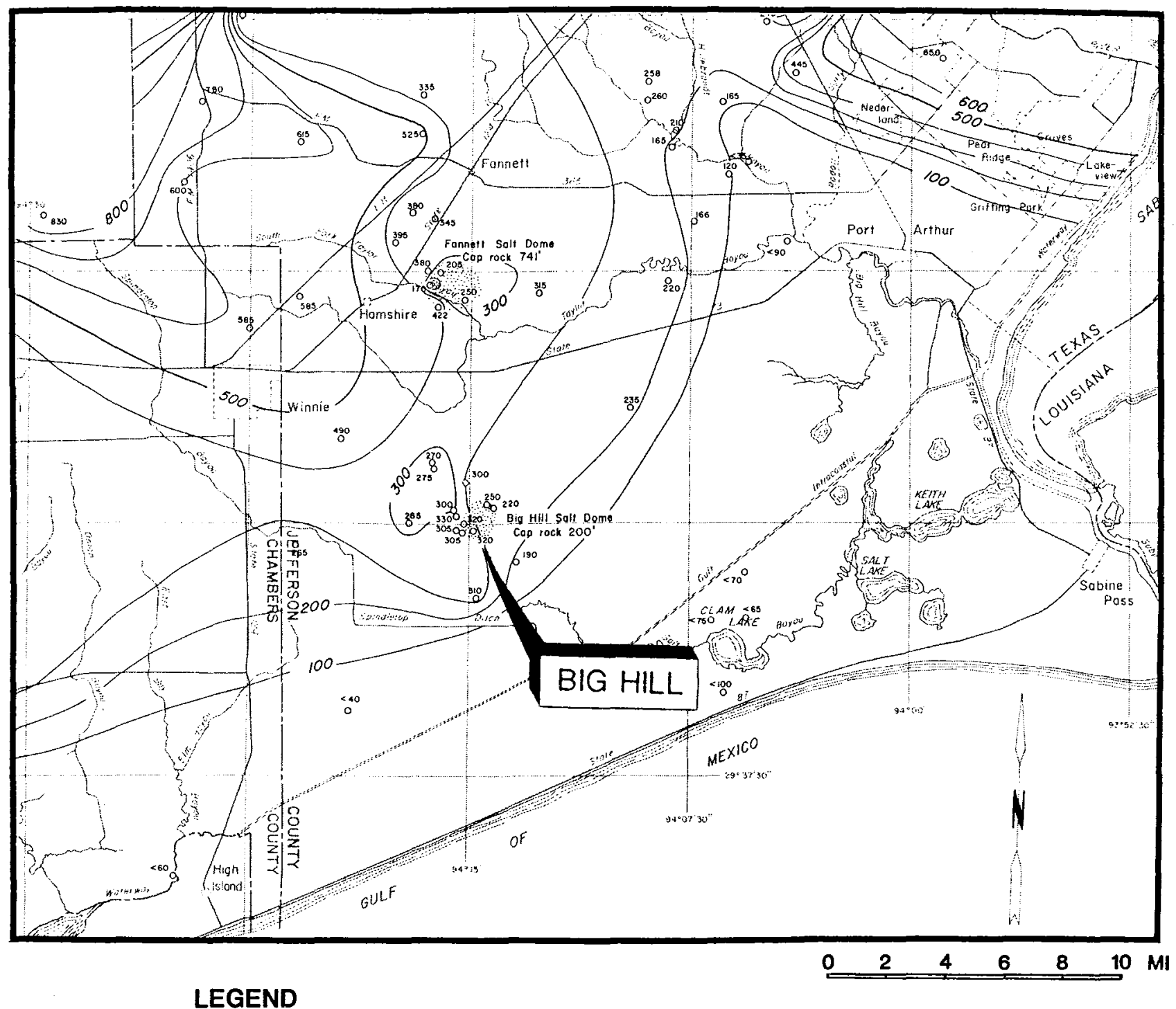

LEGEND

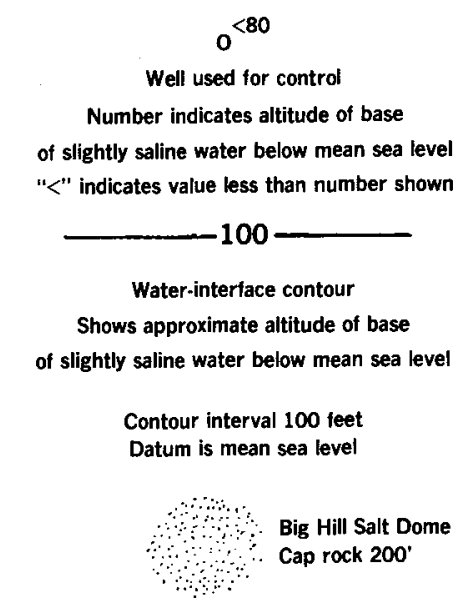

FROM WESSELMAN AND ARONOW, 1973.
BASE OF SLIGHTLY SALINE WATER

Laboratories 
CHAPTER 4 - CAP-ROCK GEOLOGY AND HYDROLOGY

Cap-Rock Geology

It is now commonly accepted that cap rock represents the product of a residual accumulation of anhydrite from a salt stock (Martinez, et al, 1978). Secondary alteration of anhydrite $\left(\mathrm{CaSO}_{4}\right)$ yields gypsum $\left(\mathrm{CaSO}_{4} \cdot 2 \mathrm{H}_{2} \mathrm{O}\right)$, calcite or 1 imestone $\left(\mathrm{CaCO}_{3}\right)$, hydrogen sulfide $\left(\mathrm{H}_{2} \mathrm{~S}\right)$, and free sulphur? Carbon for the reaction comes from the oxidation of hydrocarbons or organic matter. Free sulphur and hydrogen sulfide result from the action of sulphate-reducing bacteria (Desulfovibrio desulfuricans). A typical reaction is:

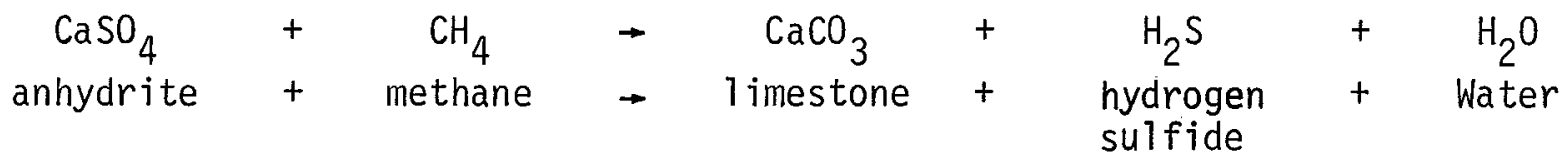

During periods of dome growth, solutioning of the salt occurs faster than uplift, resulting in formation of cavities at the salt/cap-rock contact. As cavities enlarge, overlying cap rock collapses into the voids. This process is repeated, yielding a complex sequence of lithologies in the cap rock.

\section{Cap-Rock Lithology}

Drillers' logs from sulphur-exploration wells indicate that the upper cap rock at Big Hill is composed largely of gypsum and limestone (Figure 4-2). This interval can be soft to hard, competent to fractured, and porous to nonporous. Selenite (transparent crystalline gypsum) is noted often on the core logs. Over the center of the dome, where cap rock is encountered at shallower depth, the limestone is slightly thinner. A layer of anhydrite underlies the thick gypsum and limestone sequence (Figure 4-3). The exploratory sulphur wells were abandoned when massive anhydrite was encountered because sulphur is typically found only above the anhydrite. Cap rock terminates smoothly on all flanks except the north and the west where it grades into mineralized "B" sand. A sample log of the cap rock is included as Figure 4-1.

Attempts to correlate seismic reflection data with actual depths to beds recorded in well logs indicate that the average velocity of cap rock varies considerably. The usual causes for these velocity variations are discontinuities and variations in rock type. Both well logs and seismic data indicate that the lithology of the cap rock at Big Hill is highly variable. 


\section{Cap-Rock Structure and Geometry}

The cap rock is $\cdot 200$ to $300 \mathrm{ft}$ below the surface over the center of the dome, dropping off rapidly at the flanks. The gypsum and limestone layer is 400 to $450 \mathrm{ft}$ thick over the center of the dome, increasing to 500 to $600 \mathrm{ft}$ away from the center. This upper layer of the cap rock thins rapidly to $100 \mathrm{ft}$, then pinches out on the south flank. The layer thickens to 750 to $800 \mathrm{ft}$ on the north side before grading into mineralized B sands. The underlying anhydrite is $150 \mathrm{ft}$ thick in the southern portion of the dome where it drapes over the salt and thickens to $750 \mathrm{ft}$ thick on the north side before pinching out. The total thickness of the cap rock is therefore $>1000 \mathrm{ft}$ over the center of the dome, increasing to $1350 \mathrm{ft}$ in the northern part of the dome and decreasing to $200 \mathrm{ft}$ in the southern half. The cap rock can be expected to be 850 to $1350 \mathrm{ft}$ thick in the SPR storage cavern area (Figure 4-4).

The top of the cap rock is roughly dome-shaped, rounded on the top and steeper on the edges. The shape of the massive anhydrite layer (Figure 4-3) roughly follows that of the surface of the overlying gypsum and limestone (Figure 4-2). However, the internal structure of the cap rock is very complicated. No one particular horizon in the cap rock can be followed for a large distance because of how the cap rock was formed.

\section{Cap-Rock Hydrology}

Water in the cap rock occurs in the pores or vugs of the cap rock and can be expected to be of very poor quality. One well drilled on the Union $0 i 1$ Property in 1956 penetrated to a depth very near cap rock (Table 3-6, Pure 2). Water samples taken from the interval 170 to $191 \mathrm{ft}$ in this well contained 18,850 parts per million (ppm) dissolved solids, and a sample from 219 to $307 \mathrm{ft}$ contained $23,350 \mathrm{ppm}$ dissolved soljds. Both samples were very high in sulfate, calcium, magnesium, sodium, and chloride compared to other wells in the area and would be classified as very saline at 10,000 to $35,000 \mathrm{mg} / \mathrm{L}$ (or roughly equivalent to $35,000 \mathrm{ppm}$ dissolved solids). Water in the cap rock can be expected to be of much poorer quality. Because cap-rock hydrology can affect drilling circulation and casing corrosion, water samples from the cap rock should be taken and analyzed as discussed in Chapter 6.

\section{Lost Circulation}

For the thick cap rock expected, drilling times are estimated to start at 15 days and to decrease with drilling experience. The problems that are encountered in cap-rock drilling relate to lost-circulation zones (vugs and caverns) that are found principally at the top of the cap rock, throughout the gypsum-limestone interval, and at the base of the cap rock just above the salt. Stuck pipe has occurred only at the top of the cap rock in the more recently drilled holes. Table 4-1 is a summary of cap-rock drilling records that include the thickness of the cap rock drilled, lost-circulation zones and stuck pipe, and total drilling time in the cap rock. 
Various methods are available to overcome lost-circulation problems. In view of the nature of the cap rock, preparation for circulation problems should be made and problems anticipated.

\section{Casing Corosion Potential}

The hydrogen sulfide present in the cap rock can corrode the casing in forms such as hydrogen blistering, embrittlement, and stress cracking (Hogan, 1980b). Sulfate attack on casing cement can be a serious problem unless sulfate-resistant cement is used. Retrieval and analysis of water samples from the cap rock during drilling of the SPR wells is recommended so that potential corrosion can be evaluated. Chapter 6 outlines the coring and sampling program. 
Table 4-1

Cap-Rock Drilling Summary

\begin{tabular}{|c|c|c|c|c|c|c|}
\hline $\begin{array}{l}\text { Date } \\
\text { Drilled }\end{array}$ & Well & $\begin{array}{c}\text { We1 } 1 \\
\text { Symbol }\end{array}$ & $\begin{array}{c}\text { Thickness of } \\
\text { Cap-Rock Interval } \\
\text { (ft) }\end{array}$ & $\begin{array}{c}\text { Lost } \\
\text { Circulation }\end{array}$ & $\begin{array}{l}\text { Stuck } \\
\text { Pipe }\end{array}$ & $\begin{array}{l}\text { Total Drilling } \\
\text { Time in Cap Rock } \\
\text { (days) }\end{array}$ \\
\hline 1951 & $\begin{array}{l}\text { Texaco } \\
\text { Masterson } 1\end{array}$ & K1 & 1720 & * & & 55 \\
\hline 1953 & $\begin{array}{l}\text { Texaco } \\
\text { Pipkin } 7\end{array}$ & P7 & 400 & & & 13 \\
\hline 1966 & $\begin{array}{l}\text { Goodale Bertman } \\
\text { Fitzhugh Al }\end{array}$ & $\mathrm{Al}$ & 370 & & & 9 \\
\hline 1967 & $\begin{array}{l}\text { AMOCO } \\
\text { TX Exploration } 1\end{array}$ & 1 & 220 & & 7 days & 9 \\
\hline 1966 & $\begin{array}{l}\text { AMOCO } \\
\text { TX Exploration } 2\end{array}$ & 2 & 345 & Top Cap Rock & & \\
\hline 1967 & $\begin{array}{l}\text { AMOCO } \\
\text { TX Exploration } 3\end{array}$ & 3 & 330 & $\begin{array}{l}\text { Top Cap Rock } \\
\text { for } 2 \text { days }\end{array}$ & 7 days & 7 \\
\hline 1967 & $\begin{array}{l}\text { AMOCO } \\
\text { TX Exploration } 4\end{array}$ & 4 & 580 & & & 4 \\
\hline 1967 & $\begin{array}{l}\text { AMOCO } \\
\text { TX Exploration } 5\end{array}$ & 5 & 500 & & & 3 \\
\hline 1967 & $\begin{array}{l}\text { AMOCO } \\
\text { TX Exploration } 6\end{array}$ & 6 & 450 & $\begin{array}{l}\text { Top Cap Rock, } \\
\text { Base Cap Rock }\end{array}$ & & 7 \\
\hline 1967 & $\begin{array}{l}\text { Al10C0 } \\
\text { TX Exploration } 7\end{array}$ & 7 & 325 & & & 8 \\
\hline 1967 & $\begin{array}{l}\text { AMOCO } \\
\text { TX Exploration } 8\end{array}$ & 8 & 630 & & & 3 \\
\hline 1967 & $\begin{array}{l}\text { AlMOCO } \\
\text { TX Exploration } 9\end{array}$ & 9 & 300 & & & 2 \\
\hline 1967 & $\begin{array}{l}\text { AMOCO } \\
\text { TX Exploration } 10\end{array}$ & 10 & 500 & & & 2 \\
\hline 1967 & $\begin{array}{l}\text { AMOCO } \\
\text { TX Exploration } 11\end{array}$ & 11 & 375 & Base Cap Rock & & 4 \\
\hline 1967 & $\begin{array}{l}\text { AMOCO } \\
\text { TX Exploration } 12\end{array}$ & 12 & 430 & $\begin{array}{l}\text { Base of Gypsum } \\
\text { and Limestone, } \\
\text { Base of Cap Rock }\end{array}$ & $\star \star$ & 11 \\
\hline 1967 & $\begin{array}{l}\text { AMOCO } \\
\text { TX Exploration } 13\end{array}$ & 13 & 390 & $\begin{array}{l}\text { Top } \\
\text { Cap Rock }\end{array}$ & & 6 \\
\hline 1967 & $\begin{array}{l}\text { AMOCO } \\
\text { TX Exploration } 14\end{array}$ & 14 & 350 & $\begin{array}{l}\text { Base of Gypsum } \\
\text { and Limestone }\end{array}$ & & 2 \\
\hline 1967 & $\begin{array}{l}\text { AMOCO } \\
\text { TX Exploration } 15\end{array}$ & 15 & 450 & $\begin{array}{l}\text { Base of } \\
\text { Cap Rock }\end{array}$ & & 4 \\
\hline 1967 & $\begin{array}{l}\text { AMOC0 } \\
\text { TX Exploration } 16\end{array}$ & 16 & 450 & & & 5 \\
\hline 1967 & $\begin{array}{l}\text { AMOCO } \\
\text { TX Exploration } 17\end{array}$ & 17 & 500 & $\begin{array}{l}\text { Base of Cap Rock } \\
\text { for } 3 \text { days }\end{array}$ & $1+$ & 8 \\
\hline 1967 & $\begin{array}{l}\text { AMOCO } \\
\text { TX Exploration } 18\end{array}$ & 18 & 350 & & & 2 \\
\hline 1967 & $\begin{array}{l}\text { AMOCO } \\
\text { TX Exploration } 19\end{array}$ & 19 & 650 & Top of Cap Rock & & 14 \\
\hline 1967 & $\begin{array}{l}\text { AMOCO } \\
\text { TX Exploration } 20\end{array}$ & 20 & 1090 & $\begin{array}{l}3 \text { Times at Top of } \\
\text { Cap Rock, Base of } \\
\text { Cap Rock }\end{array}$ & & 11 \\
\hline 1967 & $\begin{array}{l}\text { AMOCO } \\
\text { TX Exploration } 21\end{array}$ & 21 & 1005 & & & 9 \\
\hline \multirow[t]{2}{*}{1967} & $\begin{array}{l}\text { AMOCO } \\
\text { TX Exploration } 25\end{array}$ & 25 & 550 & & $1+$ & - \\
\hline & SPR We11s & & 1400 & & & $<15$ \\
\hline $\begin{array}{l}{ }^{\star A 1111} \\
{ }^{*} \text { Accide }\end{array}$ & $\begin{array}{l}\text { tone } \\
\text { sidetrack }\end{array}$ & \multicolumn{4}{|c|}{$\begin{array}{l}\star \star * \\
\text { Drilling time only. Does not } \\
\text { include casing and cementing time. } \\
\text { Wells were not underreamed. }\end{array}$} & \\
\hline
\end{tabular}




\section{PAN AM (AMOCO) \\ TEXAS EXPLORATION \#1}

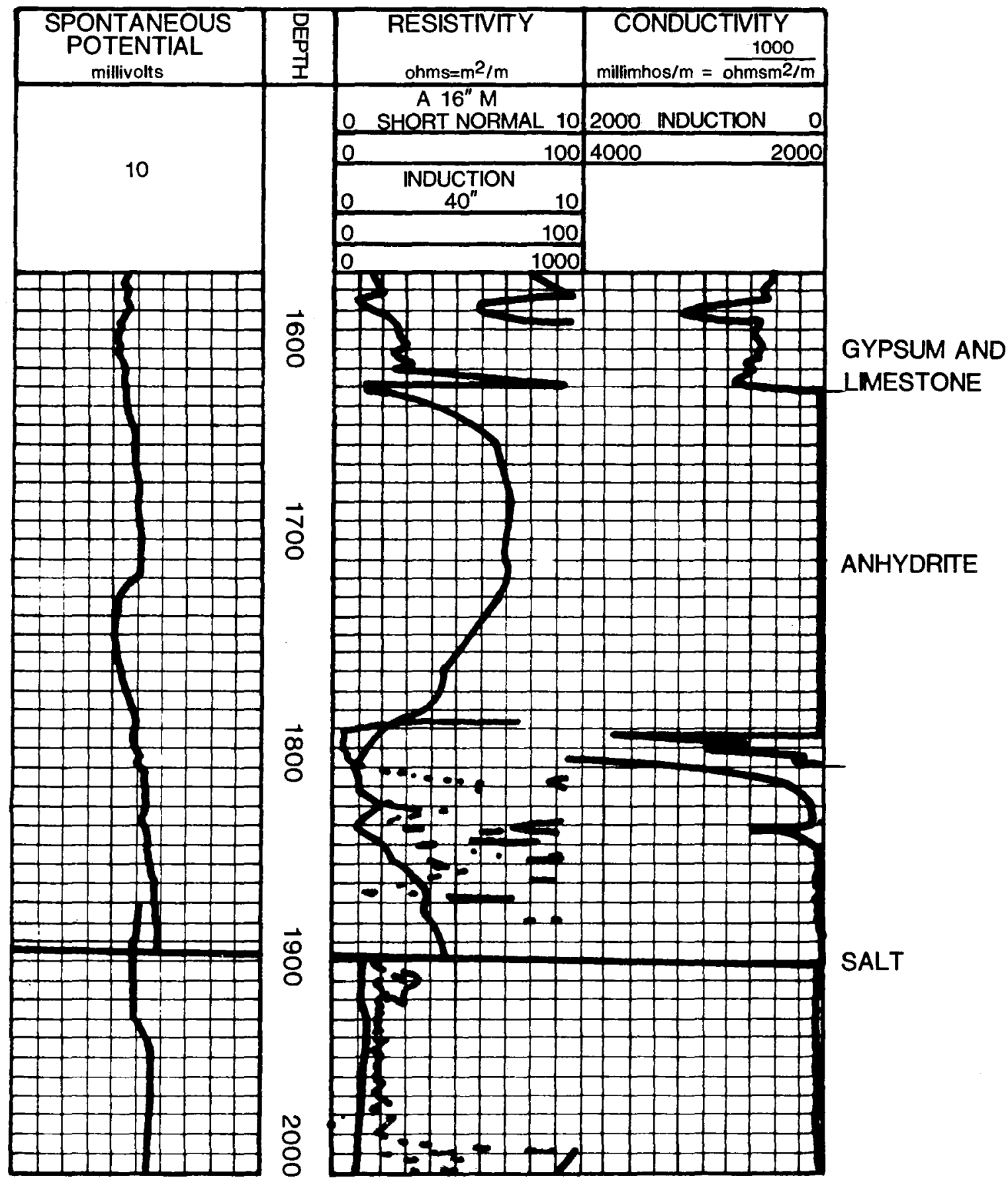

BIG HILL SALT DOME SAMPLE LOG OF CAPROCK

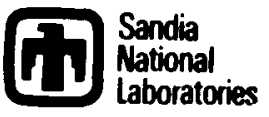

T. R. MAGORIAN

SEP 1981 FIG. 4-1 


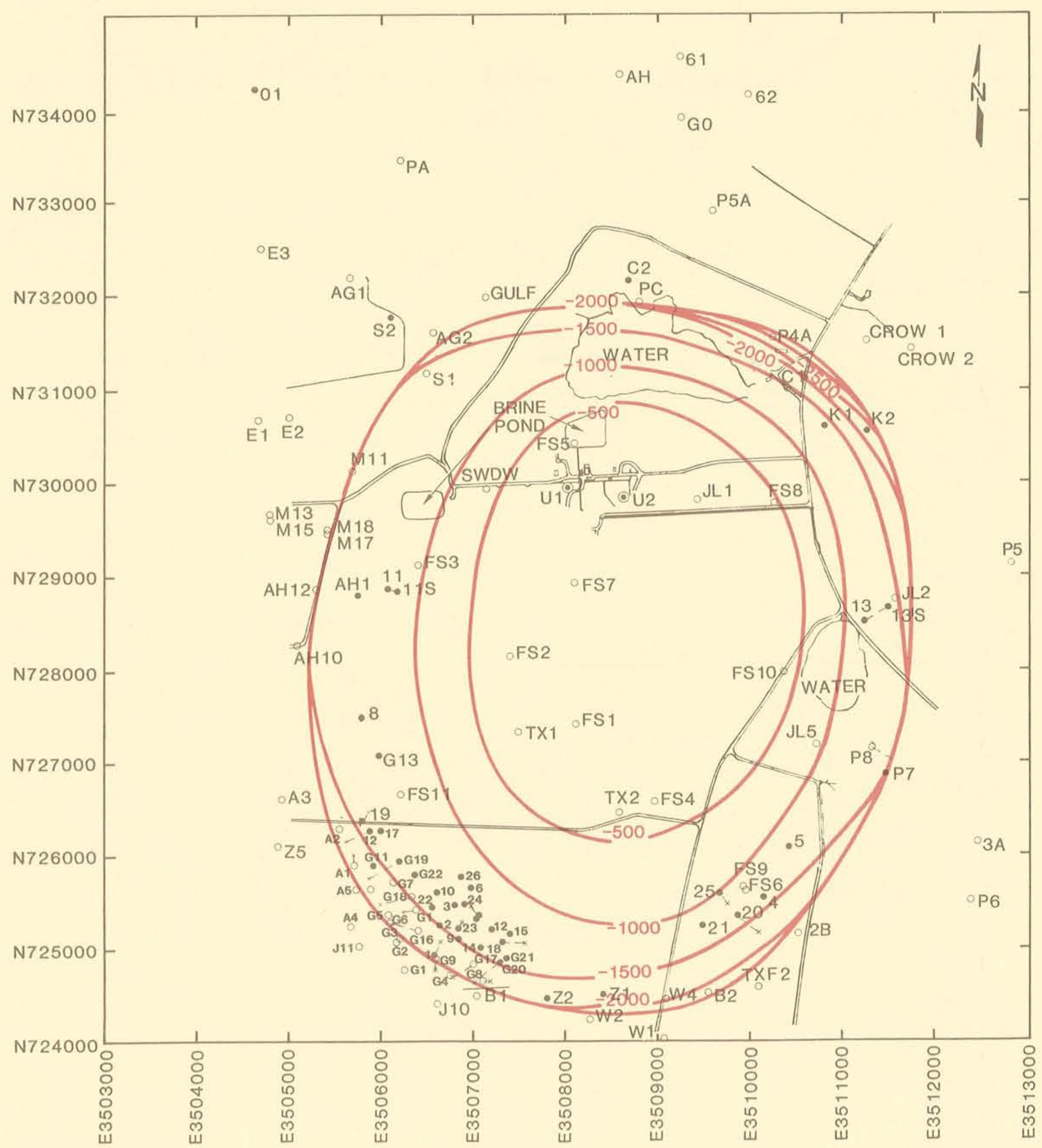

\section{NOTES}

1. SEE APPENDIX B FOR EXPLANATION OF

WELL NUMBERS AND LOCATIONS.

2. CONTOURED DEPTHS MEASURED IN FEET BELOW DRILLING FLOOR.

$$
\text { LEGEND }
$$

- U1 UNION OIL LPG CAVERN.

SURFACE LOCATION OF WEL

-G2 BOTTOM HOLE LOCATION OF WELL.

- G2 BOTTOM HOLE LOCATION OF

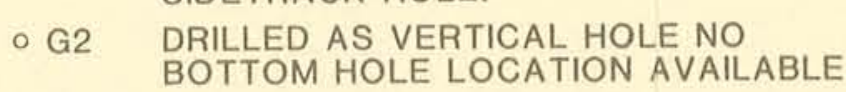

- G2

-

1000600 1000
BIG HILL SALT DOME STRUCTURE MAP -CAPROCK

\section{Sational}

T. R. MAGORIAN

SEP 1981 


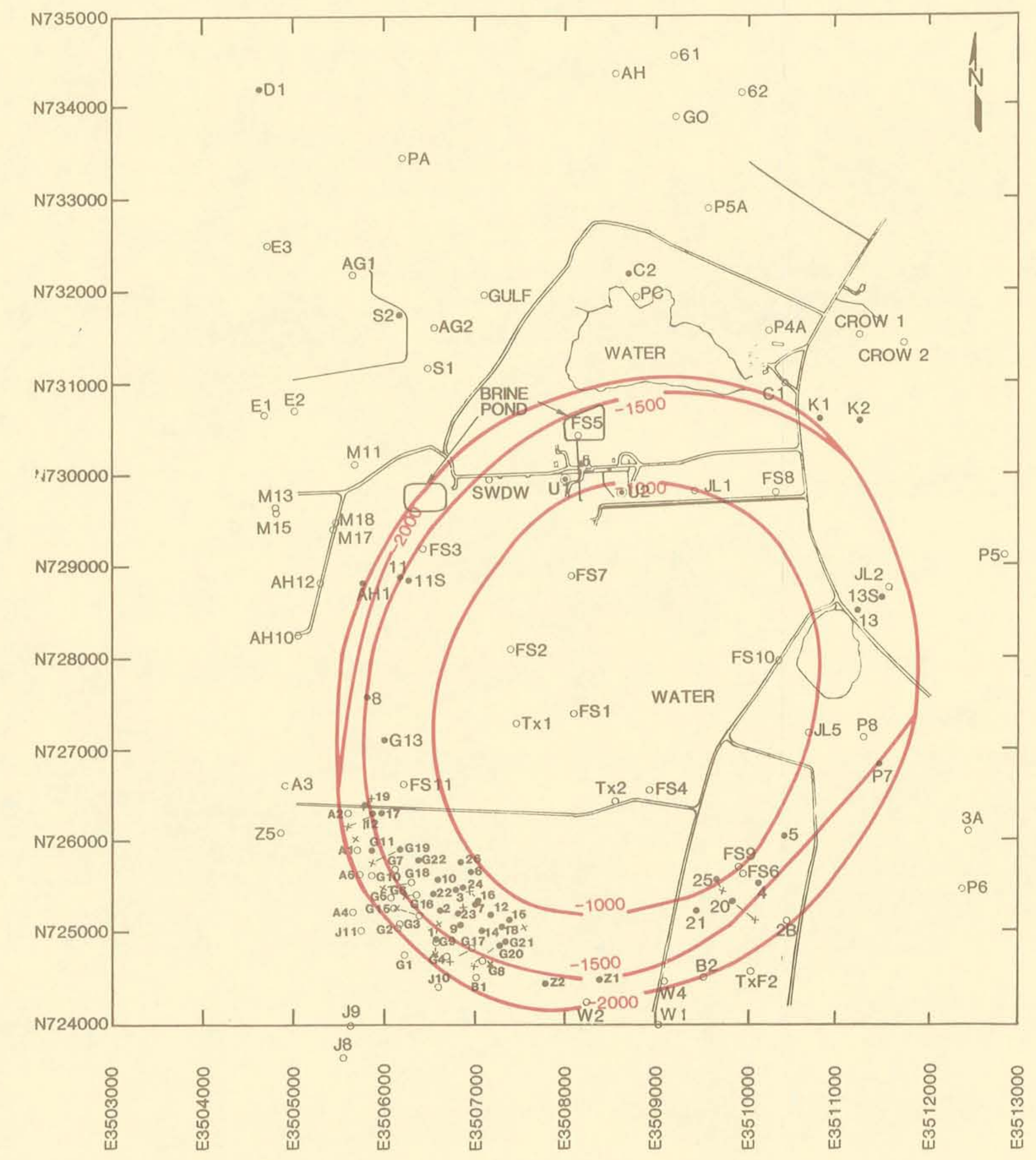

NOTES

1. SEE APPENDIX B FOR EXPLANATION OF WELL NUMBERS ANO WELLL LOCATIONS.

2. CONTOURED DEPTHS MEASURED IN FEET BELOW DRILLNG FLOOR.

U1 UNON OLLLPG CAVERN

- U1 U U.

•G2 BOTTOM HOLE LOCATION OF WELI.

!G2 BOTTOM HOLE LOCATION OF SIDETRACK

DRILLED AS VERTICAL HOLE. NO BOTTOM

G2 HOLELOCATON AVALABLE

- g2 Location OF WELl PENETRATION

500 FOOT ANHYDRITE DEPTH CONTOURS

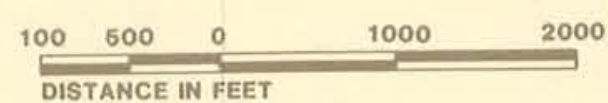

STRUCTURE MAP ANHYDRITE (1.) Sational 


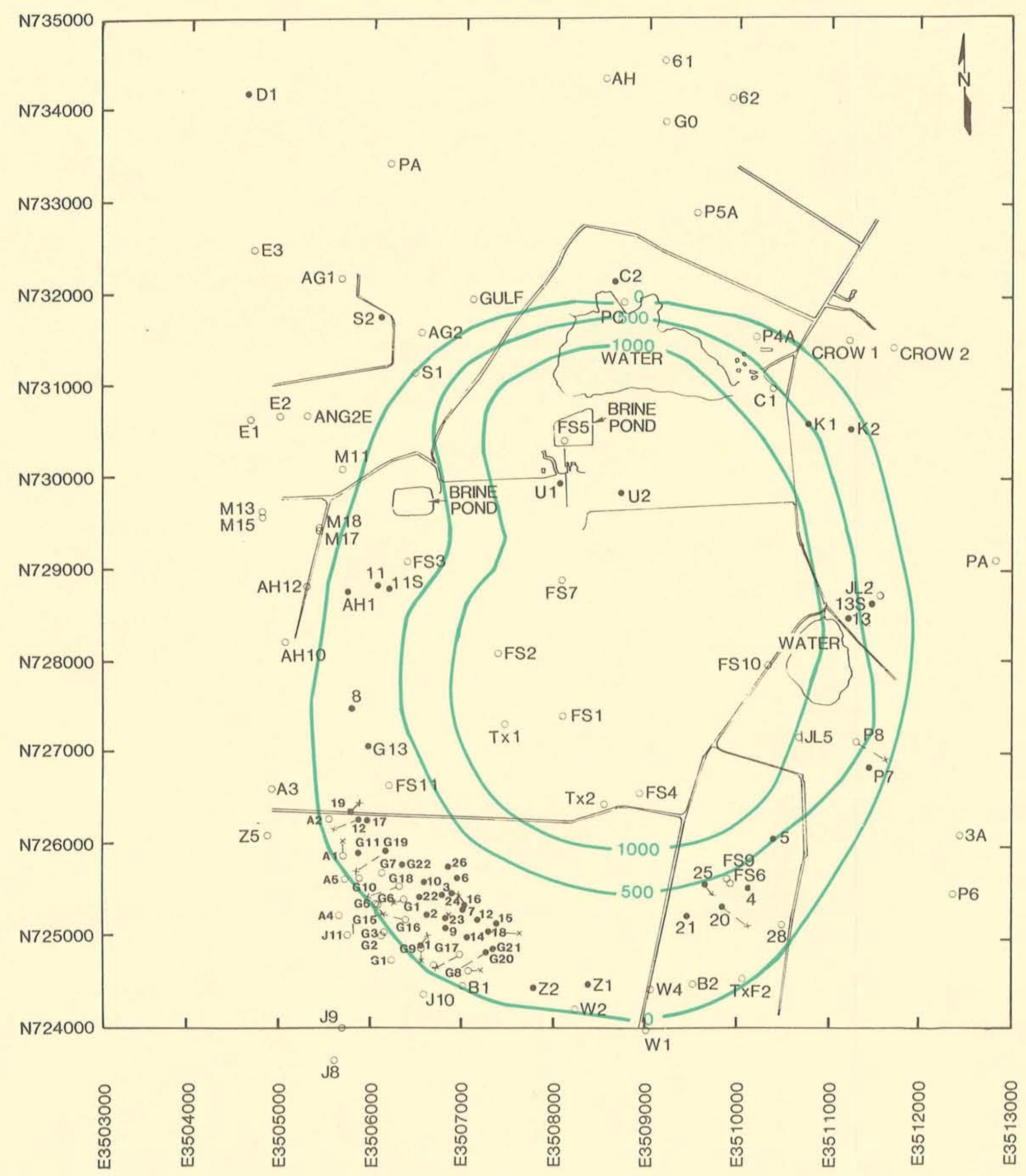

BIG HILL SALT DOME ISOPACH MAP OF CAPROCK (11) Sandianal

T. R. MAGORIAN

SEP 1981 


\title{
CHAPTER 5 - SALT-DOME GEOLOGY
}

\author{
Origin of the Dome
}

The Big Hill salt dome is a diapiric, piercement structure formed from the Louann salt formation. The depth of the Louann salt is estimated as $>30,000 \mathrm{ft}$ in the Big Hill area, although this has never been confirmed by drilling.

The most generally accepted theory on the origin of salt domes is the upward intrusion of salt into overlying sediments caused by the difference in density between the salt and sediments overlying the salt. Since salt has a specific gravity of 2.2, and the sediments vary in specific gravity from 1.7 to 2.0 at the surface to 2.4 to 2.8 at depth, at some depth the salt becomes gravitationally unstable. When the density of the overlying sediments exceeds that of the salt, the plastic behavior of salt at the high temperatures and pressures existing at depth allow the salt to migrate upward through the overlying sediments. In the Big Hill area of the Gulf coast, the salt becomes buoyant below a depth of 5,000 ft. The additional pressure and temperature required to initiate salt movement at this depth are quite small (Ode, 1968). The overlying beds that are pierced by the intruding salt are dragged upward along the salt body resulting in their being pinched out, smeared along the salt edge, incorporated into the salt, and faulted. When the salt rises to a level where the density is greater than that of the surrounding sediments, overhangs develop and the salt "slumps" back or breaks off into the lighter surrounding sediments. The mode of saltdome emplacement is well described by Kupfer (1974) and elsewhere; it is not considered necessary here to detail this previous work.

\section{Dome Geometry}

The geometry of the Big Hill dome was defined by geologic interpretations of available seismic and well-log data. The geometry is shown by a combination of depth contours on the salt surface, a series of radial and tangential cross sections, and structure maps of key marker beds surrounding the dome. Figure 5-1 shows the salt contours to a depth of $5000 \mathrm{ft}$. Figure 5-2 is the cross-section reference map showing the location of the cross sections and the 14 SPR storage caverns planned for Big Hill. Figures 5-3 through 5-7 show the major cross sections through the dome, including the planned SPR storage caverns. Figures 5-8 through 5-19 and Figures 5-20 through 5-29 are the radial and tangential cross sections, respectively, that 
were constructed to define the structure on the key marker beds (Figures 5-30 through 5-35). Accuracy of the dome geometry as shown in the salt contour map and the cross sections is $\pm 100 \mathrm{ft}$ at the 5000-ft depth.

Big Hill shows a consistent history of central domal uplift without the formation of any large rim synclines or other evidence of salt exhaustion or stagnation. The overall shape of the dome is that of a cylindrical column tilted to the south. The top of the salt lies between 1300 and $1800 \mathrm{ft}$ below the surface. The salt surface over the top of the dome is relatively flat, sloping gently outward to a depth of $2000 \mathrm{ft}$, where the angle steepens sharply. The north flank dips gently downward to $2000 \mathrm{ft}$, where the dip increases to $\sim 60^{\circ}$ between 2000 and $10,000 \mathrm{ft}$. The south flank of the dome is overhung below $2000 \mathrm{ft}$ at the same dip. The steepest dips are found on the east and west flanks. Another small overhang is indicated on the northwest flank.

The $60^{\circ}$ overhang on the south fiank has developed in the thick Anahuac shale (Table 3-2) section underlying the Miocene sand pile. The Anahuac is overpressured and of abnormally low density so that the salt is unstable above it. Frio sands (Table 3-2) are present only on the north side of the dome, apparently thick enough to help push the salt mass southward into the mud.

The weight of the cap rock, which is one of the thickest in the Gulf Coast, has also pressed the salt down. The dip of the overhang is matched by Cote Blanche and several offshore domes.

The massive salt overhang along the southern flank of the dome is documented from driliholes to a depth of $-3740 \mathrm{ft}$ (in Amoco We11 25). A11 salt contours below $-4000 \mathrm{ft}$ are projected from shallow data points except the -5000-ft contour on the west flank, which is confined by Amoco-Texas Exploration Wel1 8. There is no way to verify from existing drilling records how far the southern flank of the dome continues to dip northward below $-3740 \mathrm{ft}$. Thus exploratory extension drilling of SPR cavern wells on the periphery of the dome is recommended, as outlined in Chapter 6.

Because oil production along the southeast flank has been limited (and the wells are now abandoned), it was long believed that the south overhang was separated by a salt outlier of some sort in the middle of the south side. Interpretation of seismic reflection data shows clearly, however, that the entire south side of the dome is a single overhang with a large fault separating the areas of oil production.

\section{Geological Interpretation}

Logs from drillholes that have penetrated the salt would ideally provide the data necessary to accurately define dome geometry. To obtain a complete definition of the dome to the depths of interest for SPR storage caverns, many wells strategically located on the dome and around its periphery are required. If the dome is not upright and of fairly simple geometry, 
then a much larger number of wells are required to define the geometry. At Big Hill only 46 drillholes have penetrated the salt; and, oil exploration, not definition of the geometry of the salt, was the objective in drilling the holes, except for the Union $0 i 1$ storage cavern wells. Thus, most of the drill holes are not strategically located to define the dome geometry. In addition, the Big Hill dome is not a simple, upright, geometrical shape.

With the limitation of sparse drillhole data at Big Hill, geological interpretative methods based on strata convergence and faulting were used to define the geometry of the salt dome. The methods are based on the assumption that dome shape can be determined from the properties of the surrounding sediments and their deformational characteristics. It is well established that the dip of shales and thin-sand units next to a dome tend to be asymptotic (near vertical) to the salt at the edge of the dome.

Therefore, by projecting the increasing dip of two or more beds towards the salt, a point where the beds converge can be plotted on a geologic section. This geometric relationship allows more accurate prediction of the salt edge. Similarly, detailed evaluation of the fault geometry in the adjacent sediments also assists in defining the salt-dome boundaries.

Using we11-log data, a series of sections were constructed on and around the dome to detail the subsurface structures to a depth of $5000 \mathrm{ft}$. Lists of the depths to the tops of the geologic units used in constructing the sections are in Appendix B.

Well Control

The interpretation of the dome geometry and surrounding geology was based on 145 wells drilled on and around the dome, 99 of which did not penetrate salt. The wells of primary value in the interpretations are discussed below, with locations shown in Figures 2-1 and 5-1.

AM0C0-Texas Exploration We11 8 -- The AMOCO-Texas Exploration Wel1 8 (8) is on the west flank of the salt dome. It penetrated salt at $-1850 \mathrm{ft}$ and reached a total depth of $5200 \mathrm{ft}$, still in salt. This is the only well at Big Hill to penetrate the complete vertical interval in which the proposed caverns are to be constructed.

Stanolind-Davidson Well 1 -- The Stanolind-Davidson Wel1 1 (DI) is located $\sim 1.5 \mathrm{mi}$ northwest of the center of the surface expression of the Big Hill dome. It intersects salt at 10,114 ft and is the deepest salt penetration on the Big Hill dome. This and a few other wells show the northern flank of the dome to be a sloping surface dipping to the north.

Stanolind-Fitzhugh Wel1s 1 and 2 -- The Stanolind-Fitzhugh We11s 1 (Z1) and 2 (Z2) are the only wells giving control for the salt in the middle onethird of the southern flank of the dome. Well 1 penetrated a salt overhang from $-2200 \mathrm{ft}$ to $-2670 \mathrm{ft}$. Below the salt, productive $0 i 1$ sands were encountered down to $-5447 \mathrm{ft}$. We11 2 confirmed the overhang. 
AMOCO-Texas Exploration We11s 6, 26, and 25 -- AlMOCO-Texas Exploration Wells $6(6)$ and $26(26)$ penetrate the salt overhang along the southwest flank of the dome. Well $25(25)$ is on the southeast flank and is the deepest confirmation of the overhang with a base of salt at $-3800 \mathrm{ft}$.

AMOCO-Texas Exploration We11 13 -- The AMOCO-Texas Exploration Wel1 13 (13) is on the eastern flank of the salt dome. This well, which defines the eastern edge of the salt dome, penetrated a shale inclusion between two separate salt overhangs. The overhangs were between -1720 and $-3710 \mathrm{ft}$ and between -4120 and $-4350 \mathrm{ft}$.

AMOCO-Texas Exploration We11 11 and Adams and Haggarty We11 1 -- AMOCOTexas Exploration We11 11 (11) defines the slight overhang on the west flank next to the Sabine Pass Terminal Property. Adams and Haggarty Well 1 (AHI) confirmed the overhang.

Seismic Interpretation

Four seismic profiles, located on Figure 5-36, aided in the interpretation of the general structural information for the Big Hill area. Profiles 18 and 19 were shot in 1969 by AMOCO $0 i 1$ Company, and profiles F36 and F37 were run in 1976 by She11 0il Company. The data from these four profiles were reinterpreted in 1979 by T. R. Magorian for PB/KBB to give the results presented here.

The interpretation of the seismic record was effected by using several different digital playback filters in conjunction with a simple velocity model to "migrate" the data and form a depth section of the seismic records.

The reflector locations as shown on this depth section were then interpreted in terms of the geologic structure of the area. The velocity model used for the migration has a surface P-wave velocity of 5000 feet per second (fps), which increases linearly with depth to $7500 \mathrm{fps}$ at $5000 \mathrm{ft}$. This gives an average velocity of 6250 fps for the sediments as contrasted to the constant $15,000-f p s$ velocity used for the salt.

Based on the above interpretation schemes alone, the limits of the dome have been established to within $\pm 400 \mathrm{ft}$, and the overhang in the southern quadrants of the dome has been shown to extend to at least $5000 \mathrm{ft}$. In addition, two faults, possibly of Hackberry age, F5 and F6, Figure 5-12, have been delineated.

The complicated structure of the Big Hill dome makes it very difficult to define an absolute vertical or horizontal profile. The resultant large error, however, has been significantly reduced by using other information in conjunction with the seismic interpretation. 
Structure and Stratigraphy

The dome is overlain with Pleistocene sediments. The sediments flanking the dome are steeply dipping sands and shales of Pliocene, Miocene, and 01 igocene age. As in other types of intrusions, the salt dome must displace the overlying sediments as it is emplaced. When uplift proceeds, any sediment deposited over the top of the dome must be either pushed aside or eroded away. On domes with a surface expression such as Big Hill, sediments are eroded off the top of the dome as it rises. As each layer of sediment was deposited over the dome, the upward movement of the salt stretched it to the point of failure, essentially pulling the layer apart in a series of normal faults. The mechanical failure of the sediments surrounding the dome has caused the faults to develop radially from, and tangentially to, the dome in a series of graben and horst structures.

Radial and tangential sections and structural maps were constructed from well-log data and used to define the subsurface structure surrounding the salt dome. The structure contour maps on the surfaces of the major marker horizons, as shown in Figures 5-30 through 5-35, were drawn to define the salt edge at different elevations and show the lateral extent of faulting. Because the faults are created by the intruding salt, their pattern helps predict the location of the salt dome. The hatched areas on the structural maps show where the key marker units are absent. Their absence is caused by the structural offset of the unit by normal faulting. As the structure maps show, the extent and magnitude of faulting increase with depth. Fault offsets of Pliocene age are on the order of 10 to $30 \mathrm{ft}$; those of the Anahuac are up to $1000 \mathrm{ft}$. Sections were drawn radially and tangentially to the dome in order to orient them as near normal as possible to both the radial and tangential faults. If a section is not oriented normal to the fault, the apparent dip of the fault plane will be less than the true dip of the fault.

\section{Major Cross Sections}

The section reference map, Figure 5-2, shows five major cross sections cutting completely across the dome. These sections show the overall shape of the dome and the relationship of the planned SPR storage caverns to the dome boundaries. Two of these five sections, the southwest-northeast and the northwest-southeast sections, were taken through control wells to provide good definition of the overall shape of the dome and the salt boundaries. The other three sections were constructed through the three rows of planned SPR caverns in a nearly west-east direction. These sections were taken to show the steep east and west flanks of the dome at critical depths and the relationship of the planned SPR caverns to the salt boundaries. These three sections, however, lack the well control for a high-confidence definition of the dome edges or the cap rock. The simpler appearance of the cap rock in these three sections compared to the SW-NE and the NW-SE sections simply indicates a lack of enough data to accurately define the cap-rock structure. 
Southwest-Northeast Cross Section (Figure 5-3) -- This north-south section extends completely across the dome and is shown to the total depth of available well control. The rounded lip of the salt on the south side underlies the convergence and pinchout of the Pliocene and lower Pleistocene sands.

Growth Fault F12 causes the abnormal dip of the Montgomery and underlying Pleistocene sediments in the PC and $C 2$ wells. This section shows the location of planned SPR Cavern 114 relative to the edge of the dome on the southwest flank.

Northwest-Southeast Cross Section (Figure 5-4) -- This section extends completely across the dome and is shown to the total depth of available well control. The rounded blunt end of the overhang on the east side is very close to the P8 well. Cap rock terminates smoothly without extensive mineralization of sands. On the west side, however, the cap rock grades into mineralized B sands just above the unconformity. Planned SPR Caverns 104, 105, 106, and 107 are projected into this section. The proximity of SPR Cavern 106 to the edge of the southeast flank of the dome is shown. Because very little well data are available to define salt contours on the southeast flank, the proximity of SPR 106 to the dome edge is of concern. An extension drilling program as outlined in Chapter 6 is recommended to alleviate this concern.

West-East Cross Section No. 1 (Figure 5-5) -- This section was constructed to show the relationship of the first row of the planned SPR caverns to the east and west flanks of the dome and the top of the salt. Projecting from AMOCO Well 11 south to AMOCO 8 shows that the salt is nearly vertical on the west side. AMOCO Well 13 and its sidetracked hole give control to the definition of the east flank in the interval from $-1730 \mathrm{ft}$ to $-3710 \mathrm{ft}$. The Lafayette gravel is almost entirely cut out in Wel1 13. Other wells that penetrate the Lafayette close to the dome show a constant thickness for the Lafayette; the cutout in Well 13 is therefore interpreted to be a fault, and is shown in this cross section as F14. This section shows the potential space remaining on the west side for an additional cavern (see Chapter 6).

West-East Section No. 2 (Figure 5-6) -- This section through the middle row of planned SPR caverns also illustrates the steep east and west flanks and the relationship of the SPR caverns to the top of the salt and the edge of the dome. In this section it is also clear that space remains on the west side for an additional cavern beyond the baseline, as discussed in Chapter 6 . Definition of the cap rock from Well G13 on the west side of this section is uncertain. The top of the limey material may be as shown or as deep as $1300 \mathrm{ft}$. The anhydrite is thin but a reliable marker. The top of the salt is reliable. There is no control for the east flank or for the sediments on either flank.

West-East Section No. 3 (Figure 5-7) -- This section through the bottom row of planned SPR caverns, like the previous two sections, graphically illustrates the SPR cavern-salt dome relationship. Construction of this row of SPR caverns involves the greatest geological risk because the caverns are the farthest out in the overhang on the south flank. The recommended extension drilling program outlined in Chapter 6 will reduce the risk of a cavern leak in the future. Control is available on both the east and west flanks through the cap rock (A2 and P7) and through the salt on the west flank (AMOCO 19). The dome narrows as the overhang converges on the south flank. 


\section{Radial Sections}

Construction of radial cross sections is needed for accurate estimation of the salt's geometry. The controlling tectonic stresses and resultant salt geometry are observed in the fault patterns that appear on both radial and tangential sections. Both types of sections are needed to define the salt dome in three dimensions.

Tine extent of the south overhang can be seen in the radial sections taken around the south flank of the dome from A-A' (Figure 5-8) just south of the steep west side at Well 8, through Section $\mathrm{H}_{-1} \mathrm{H}^{\prime}$ (Figure 5-15).

Section $A-A^{\prime}$ (Figure 5-8) -- The southwest radial section through brine disposal Well 19 shows the steepening of the overhang as it swings around from the south flank of the dome into the near-vertical west side. The vertical salt wall extends upward from the mid-Miocene Amphistegina B shale.

Section $B-B^{\prime}$ (Figure 5-9) -- The radial section across the producing area west of FI (Figure 5-34) shows the same projection of the salt overhang as $A-A^{\prime}$, with matching dips of the lower Miocene sands. The deep we11s (10 and 26) allow interpretation of the Marginulina sand within the geopressured Anahuac Shale. Both beds dip at the same steep angle up to the salt. The Marginulina sand was unproductive in both wells but has produced highpressure gas over several square miles to the west (the Big Hill Northwest field). The risk of a gas blowout during the drilling and leaching program will require detailed evaluation as information is obtained from the proposed wells.

Section C-C' (Figure 5-10) -- This radial section across the middle of the producing area sinows a rounded salt edge above the $D$ sand and a simple overhang surface below. The well control available in this small area assures the simplicity of this interpretation. The maximum extent of the salt coincides with the top of the Miocene, marked $A$ in the section. Beds below the salt bulge are uplifted at the same $60^{\circ}$ angle as the salt overhang.

Section D-D' (Figure 5-11) -- The radial section across the southeast end of the producing area shows a linear overhang. The abundant well control assures the linearity of the overhang, and thus confidence in its extension to the bottom of the proposed caverns. Thinning and convergence of all the Miocene beds is observable because they are uplifted at the same $60^{\circ}$ angle formed by the salt overhang itself.

Section E-E' (Figure 5-12) -- This short radial section, located at the middle of the south flank, siiows a sharp stratigraphic convergence against the salt overhang and two faults, marked F5 and F6, parallel to the overhang. The shallow salt edge is rounded by dissolutioning and extends farthest east at the top of the Miocene. The 1ocations of Faults F5 and F6 have been confirmed by the north-south shell seismic line.

Section $F_{-} F^{\prime}$ (Figure 5-13) - - This radial section across the southeast flank shows the linearity of the south-flank overhang, and the convergence of the beds confined to the lower Miocene. The lower Miocene sands are uplifted to $45^{\circ}$ dip; the upper Miocene $B$ sands are nearly flat. 
Section G-G' (Figure 5-14) -- This detailed radial section through the middle of the southwest producing area shows a sharp change in slope of the salt overhang at the level of intersection with the main D sand. A fault, F13, which is parallel to a 300-ft array from the salt edge, has allowed 300 ft of lower Miocene sediments to slip downward against the salt, forming a sort of graben in the salt-contact zone.

Section $\mathrm{H}_{-} \mathrm{H}^{\prime}$ (Figure $5-15$ ) -- This detailed radial section across the southwest flank shows truncation of Fault Fl close to the salt. The transition in slope of the salt overhang here occurs at the unconformity between the $B$ and the $C$ sands. A wedge of sediments is apparently trapped between the steep salt wall and $\mathrm{Fl}$; there is no evidence, however, that this extends farther into the salt mass as an inclusion. No inclusions have been found in any of the overnang salt penetrations, unlike the near-vertical salt on the east side of the dome (We11 13). Steeper $80^{\circ}$ overhangs very commonly contain inclusions, but this $60^{\circ}$ overhang appears too heavy and massive to allow their survival.

Section J-J' (Figure 5-16) -- This northwest radial section shows a smooti northward slope of the salt from cavern Well U1, one of the existing storage caverns, down to Well S2. The graben, or down-dropped block, between Fault F8 and the salt does not seem to affect the salt surface, insofar as available well control indicates. The graben is filled with lower Miocene sands, particularly the main D sands, during which F8 acted as a growth fault.

Section $K^{-K^{\prime}}$ (Figure $5-17$ ) -- The east radial section shows a $100-\mathrm{ft}$ thick inclusion that has separated a long wedge of salt from the main mass of the overhang at the point where it steepens along the near-vertical east side. Although this sliver of salt is not entirely loose, it is probably trapped along Fault F5.

Section $L-L^{\prime}$ (Figure 5-18) -- The section through the northwest overhang and the steep west flank shows the maximum extent of the salt occurring opposite the upper Miocene B sands. These sands are highly mineralized. Both $D$ and $E$ sands thin dramatically and are pulled up into a near-vertical position. There is not enough control to determine any probable faulting that complicates this situation. The overpressured Anahuac shale, marked by its top, the Discorbis, restricted (DR), is dragged up, but the shale sheath common to Gulf Coast salt domes has not yet been found at Big Hill. The geodynamics of a large $60^{\circ}$ overhang make survival of the shale sheath or diapir very difficult. That is, the weight of the salt overhang has probably squeezed any shale out at the shallow depths to which the dome has been drilled. If the south flank overhang steepens up to yield space for additional storage caverns, this flank may àlso be protected by a shale sheath.

Section $M-M^{\prime}$ (Figure 5-19) -- This radial section through the northwest overhang shows protruding salt that has dropped into the sediments. The overhang is limited to the area north of Well 8 and may steepen with depth. There is no control, however, to clarify the details of this complex area. 
Shales are relatively impermeable and will be added protection to the oil stored in caverns near the edge of the salt in contrast to more permeable sands. The shale-sand sequence at the depth of the proposed caverns can be noted in the radial sections (Figures 5-8 through 5-19). Shale "squeezeouts" or sand convergences against the salt are also shown on these radial sections. Ideal cases appear in We11s 23 (Figure 5-10) and G20 (Figure 5-11). The convergence of sands defined from well control near the salt edge is a useful tool for defining the location of the salt edge. One or more tangential faults dipping away from the dome often occur where the converging sediments have been steeply uplifted.

\section{Tangential Sections}

The tangential sections provide the details of the salt dome needed to delineate radial faults and to correlate the radial sections. Many of these faults are actually parallel to tangentials at the edge of the dome. The tangential sections complete the three-dimensional picture of the dome for a more accurate description of the salt boundaries. They should be used in association with the radial sections and the structure maps showing the tops of the various marker beds.

A complete traverse around the dome is shown in tangential sections iN- $N^{\prime}$ through $Y-Y^{\prime}$ (Figures 5-20 through 5-29). All of the major radial faults as well as the largest tangential faults are revealed in these sections, making the discovery of additional overhangs much less likely.

Section $\mathrm{N}^{-N^{\prime}}$ (Figure 5-20) -- The outside tangential section across the southwest-producing area shows the Faults F1 and F2 that form the hydrocarbon-producing structure: a horst or block between the intersecting normal faults below the mid-Miocene unconformity. Inside the horst, the C-sand dips northwest and the basal E-sand dips southeast because of growth in the D-sands along FT.

Section P-P' (Figure 5-21) -- The east-west tangential section across the south side of the dome shows the large fault, F5, which extends upward at least through the Miocene. F5 has $1000 \mathrm{ft}$ of throw at the top of the Anahuac. This fault dominates the section, cutting the lower salt in Well W4. The salt dome structure is broken by the fault dipping east and west at $60^{\circ}$ angles below the fault and $30^{\circ}$ angles above. Fault F6, forming the graben parallel to the salt overhang, may displace F5 where the two faults cross. Fault F6 also displaces the salt in Wel1 22.

Section R-R' (Figure 5-22) -- This tangential section along the southeast flank shows two paralle1 faults, F6 and F7, in the 1ower Miocene. The arch structure found in all of the beds in this section is simply caused by the intersection of the tangential section with the dome. The faults are tangential and parallel to the salt overhang as shown in the radial sections. 
Section S-S' (Figure 5-23) -- This section tangent to the southeast flank of the dome shows a fault across the section at an oblique angle. The salt is displaced by F5, as shown in We11 25. The thickening of the Dsand is associated with reversal of dip in Well 5. This structure produced oil for some years. The beds, which show drag near Fault F5, al so steepen toward We11 P8, indicating a structural high to the east.

Section T-T' (Figure 5-24) -- The tangential section running northsouth along the east side of the dome shows the north end of the isolated salt finger found in well 13 where it joins the main salt mass and dips steeply northward. Fault F5 has no observable displacement on the salt, although that is probably only because of lack of well control. In this section, the Miocene beds below F5 appear to dip into the salt overhang. The dip away from the salt is normal on the north flank.

Section U-U' (Figure 5-25) -- The section tangent to the northeast flank shows a small but sharp uplift in Well C2. The top of the salt is displaced by Fault F11. A gentle dome over the salt ridge in Well Kl extends to the top of the Miocene Sediments.

Section $V_{-} V^{\prime}$ (Figure 5-26) -- The tangential section across the north side of the dome shows a simple, rather gentle west dip. The E-sand, and to a lesser extent, the D-sand, thicken to the west, particularly on the down side of $F 8$ (as shown in the graben discussed in the northwest radial section). The mid-Miocene shale (AB) also thickens in Wells S2 and AG1.

Section $W-W^{\prime}$ (Figure 5-27) -- The section tangent to the dome across the northwest flank shows lower Miocene beds dipping steeply to the southwest near the fault that cuts through the Gulf well. The salt domal structure to the southwest is mostly caused by thickening in the Siphonina davisi shale and the underlying E-sands in Well Ml1. In general there is almost no dip here. The B sands are thicker in Well M17. This amount of stratigraphic variation is normal and traps oil both against the salt and in other fault contacts and bed pinchouts.

Section $X-X^{\prime}$ (Figure 5-28) -- The tangential section running northsouth on the west side of the dome shows a gentle southward dip interrupted by Fault F9. The fault extends upward to the mid-Miocene unconformity. The eastward extension of $F 9$ into the salt mass helps create the small northwest overhang shown in the radial sections $K-K^{\prime}$ and $L^{-} L^{\prime}$ through Wel1 11 .

Section $Y-Y^{\prime}$ (Figure 5-29) -- This inner tangential section across the southwest producing area shows the intersection of F1 and F2 with the salt overhang. The lower Miocene sands in the productive horst are dipping northwest at $60^{\circ}$. Curvature of the underside of the salt is partly a function of available well control, because any slight deviation from the ideal 1 ine of section will produce an anomaly when the dip of the sediments is steep. 


\section{Structure Contour Maps}

Figures 5-30 through 5-35 show structure contour maps on the tops of the A through $E$ sands and Anahuac shale. These maps, essentially slices through the dome, were drawn to define the salt edge at the level of the particular unit being mapped. The maps show the dip of the salt northward with depth. The amount of displacement on the top of the units also increases with depth, showing the effect of dome uplift on the surrounding sediments. Many of the sands close to the dome have produced gas and oil. These reservoirs tend to be segmented by faulting associated with dome growth. Mappable fault displacement stops at the dome since any displacement becomes indistinguishable because of the plastic, self-healing nature of the salt.

Dome-Related Faulting

Mapping faults is useful in defining the edge of the salt since dips on fault planes depend on lithology. Faults through loose sands generally dip at $60^{\circ}$; steeper dips occur in the more consolidated sediments. The salt edge is technically a fault surface. In the silty, consolidated turbidites of the Frio Formation, which is overpressured, dips of faults can range down to horizontal. Once a fault is formed, it continues to grow as additional sedimentary layers are deposited and the dome continues to rise. Therefore, the fault offset decreases upward along the fault plane. Although the displacement of some of these dome-related faults is on the order of hundreds of feet at the dome edge, the faults die out rapidly away from the dome, generally in less than $1 \mathrm{mi}$.

Mapping of the dome-related faults has been based on electric log data. Faults can be interpreted from the logs by correlation of the major stratigraphic horizons such as the Miocene A through $E$ sands. Offset of these major units infers faulting. Because of the sparse well control on and around the dome, only some of the faults can be correlated with those in the surrounding wells to determine the orientation of the fault planes. The accuracy of determining the amount of offset depends on the lithology of the sediments the fault passes through. In shales, for example, the resolution of an electric $10 \mathrm{~g}$ is good to within $2 \mathrm{ft}$; while in coarse, cross-bedded levee or channel sands, a fault with $200 \mathrm{ft}$ of offset may be obscured. Where the sediments show a linear drop on the downthrown side of the fault, the salt shows a curved updrag.

Fourteen major faults (labeled F-1 through F-14, Figures 5-3 through 5-35), have been defined around the dome. Many more smali-scale faults (displacement in the tens of feet) probably exist, but are not considered critical to defining the salt dome. The remaining faults offset only Miocene and older sediments and are considered "inactive."

Faults F4 (Figure 5-4) and F12 (Figure 5-3) on the dome appear "active" in the sense that they continue to grow with increased sedimentation and salt-dome uplift. Movement along this type of fault is a gradual slippage that will have no adverse effect on the SPR site. Fault F4 on the west side of the dome has been cut on the top of the Pliocene and appears to reflect the area of maximum salt uplift today, forming the active margin of the dome. 
$0 i 1$ is produced from the associated trap in We11 M17. There is an anomalous dip down toward growth Fault F12 on the north flank. This fault displaces sediments to the surface (Figure 5-3).

The major faults are both radial from, and tangential to, the dome. The radial faults appear on many of the structure maps to strike through the salt mass. For example, Fault F-7 on the A-Sand structure map (Figure 5-30) strikes out of the northwest and southeast flanks of the dome. This is because many radial faults originally formed tangential to the dome. As the salt dome moved upward, it passed through the fault plane, destroying it but leaving traces of the plane away from the dome intact.

\section{Salt Mineralogy}

Most salt domes in this area of the Gulf Coast are nearly pure halite. The major impurity found is anhydrite, which is generally present in amounts from $1 \%$ to $10 \%$. Studies of salt mines at other domes have revealed inclusions of sediments, gas, brine, and petroleum within the salt mass (Kupfer, 1974). Although no core of the Big Hill salt dome is available for testing, salt was cored from Pure 011 \#1 (now Union 011 \#1) and analyzed for insolubles. The average of three samples taken from the top, middle, and bottom of that well was $3.2 \%$ insolubles. A detailed coring and logging program as well as a materials testing program are outlined in Chapter 6.

Several thin salt sections have been logged along the western and eastern edges of the dome where the salt overhangs into the soft sediments (Figure 5-17). These sections are either inclusions of sediment in the salt mass, or pieces of detached salt that have separated from the main body of salt. Salt inclusions in the sediments are eventually dissolved; however, sediment inclusions inside the main salt mass are better preserved. No inclusions have been found on the south side.

The AMOCO-Texas Exploration Well 8 on the west flank of the dome penetrated salt at $-1850 \mathrm{ft}$ and reached a total depth of $5200 \mathrm{ft}$, still in salt. This is the only well to penetrate the complete interval where the proposed SPR caverns are to be constructed. An electric log is the only log available for this well, as is the case for most wells (see Appendix B). The electric log indicates that the salt is of good quality throughout the entire interval of the proposed caverns. However, an electric log can give only a partial analysis of salt quality, and a testing program as outlined in Chapter 6 should be carried out. Also, the quality of the salt may vary from place to place on the dome. 


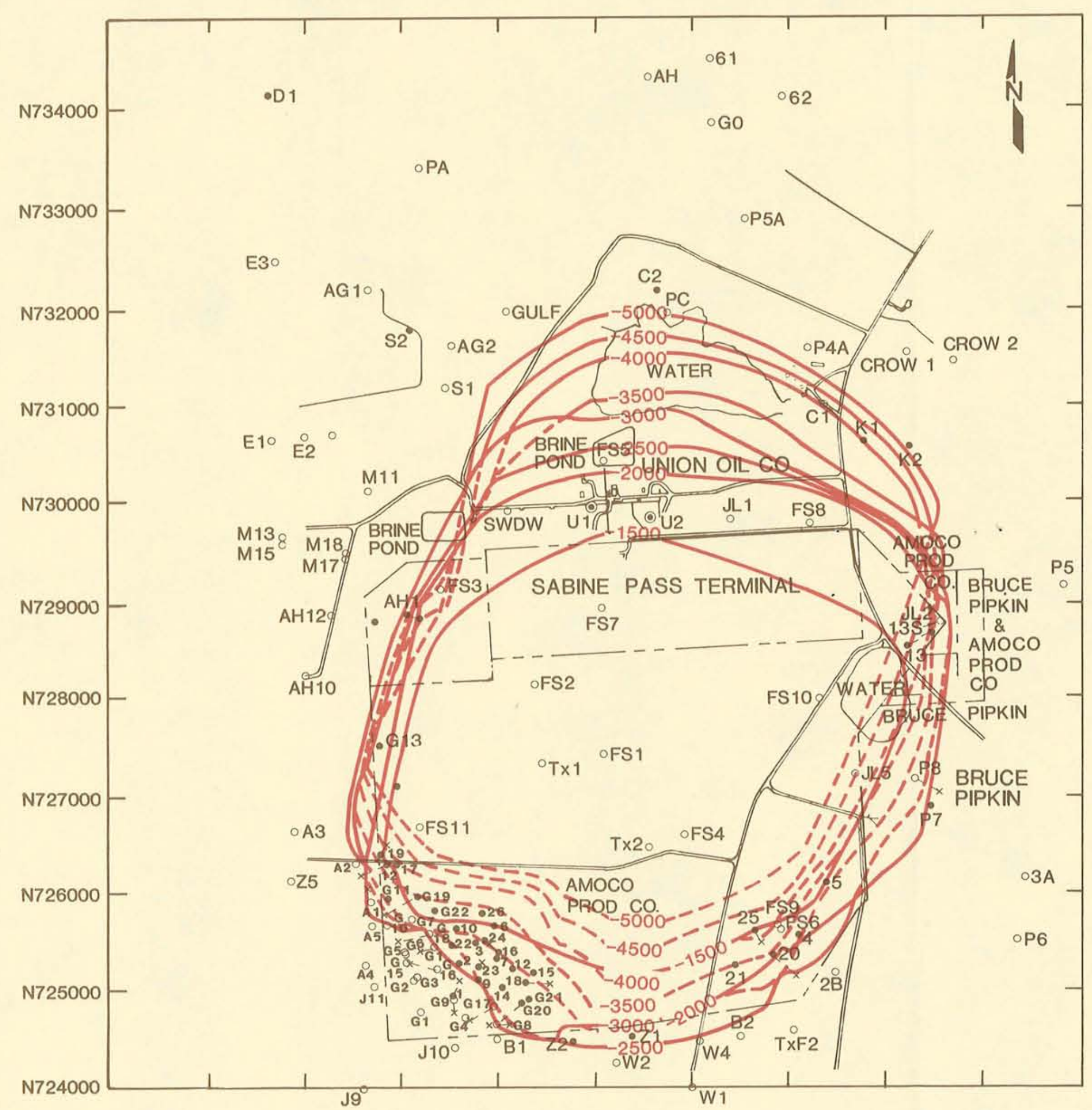

NOTES

1. SEE APPENDIX B FOR EXPLANATION OF WELL NUMBERS AND

2. CONTOURED DEPTHS MEASURED IN FEET BELOW DRILLING FLOOR.

$$
\text { LEGEND }
$$

- U1 UNION OIL LPG CAVERN.

SURFACE LOCATION OF WELL.

- g2BotTOM HOLE LOCATION OF WELL.

-G2 BOTTOM HOLE LOCATION OF

- G2 DRILLED AS VERTICAL HOLE . NO BOTTOM HOLE LOCATION

G2 LOCATION OF WELL PENETRATING SALT.

-SALT DEPTH CONTOURS

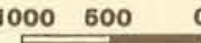

DISTANCE IN FEET
BIG HILL SALT DOME STRUCTURE MAP-SALT 团的到

T. R. MAGORIAN

SEP 1981

FIG. 5-1 


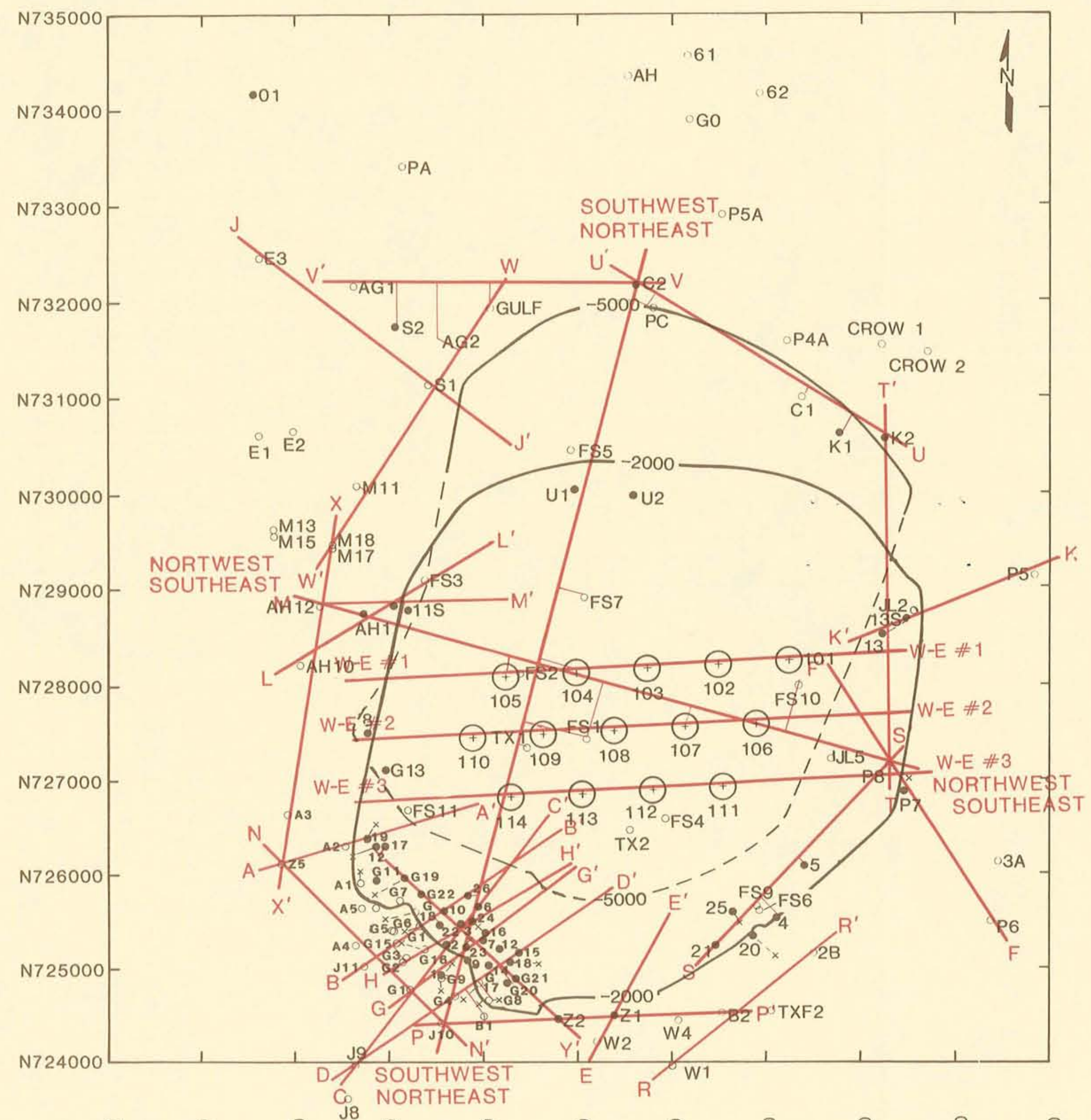

NOTES

1. SEE APPENDIX B FOR EXPLANATION OF WELL NUMBERS AND WELL LOCATIONS.

$$
\text { LEGEND }
$$

PG CAVERN

$\times$ SUREACE LOCATION OF WEL

- BOTTOM HOLE LOCATION OF WELL.

G2 BOTTOM HOLE LOCATION OF

G2 DRILLED AS VERTICAL HOLE. NO BOTTOM

( PROPOSED SPR CAVERNS

101 SECTION LINE

WELLS PROJECTED TO SECTION LINE

$000500 \quad 0$

$1000 \quad 2000$

DITANCE

BIG HILL SALT DOME

SECTION REFERENCE MAP 


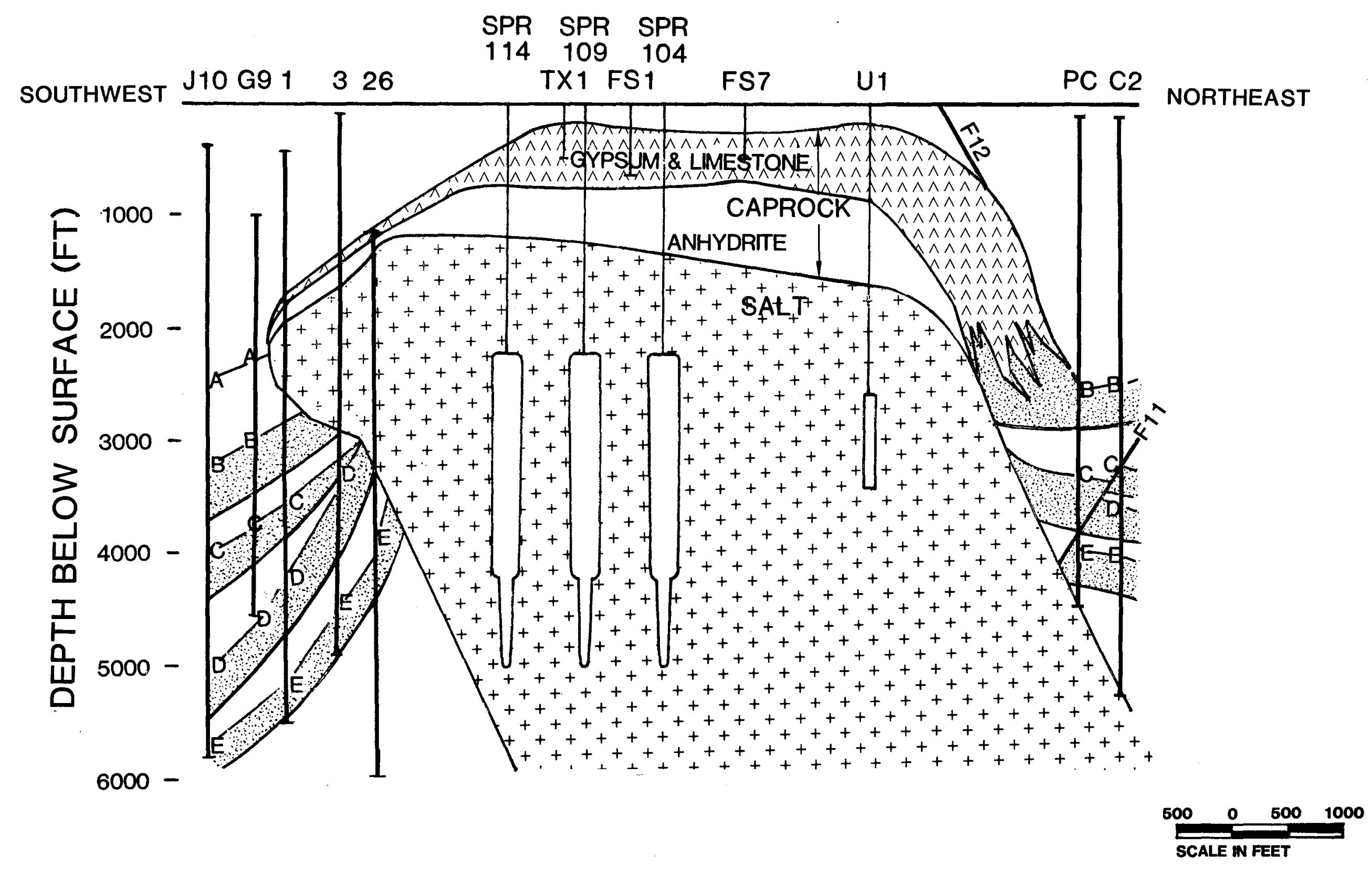

BIG HILL SALT DOME SOUTHWEST-NORTHEAST CROSS SECTION 


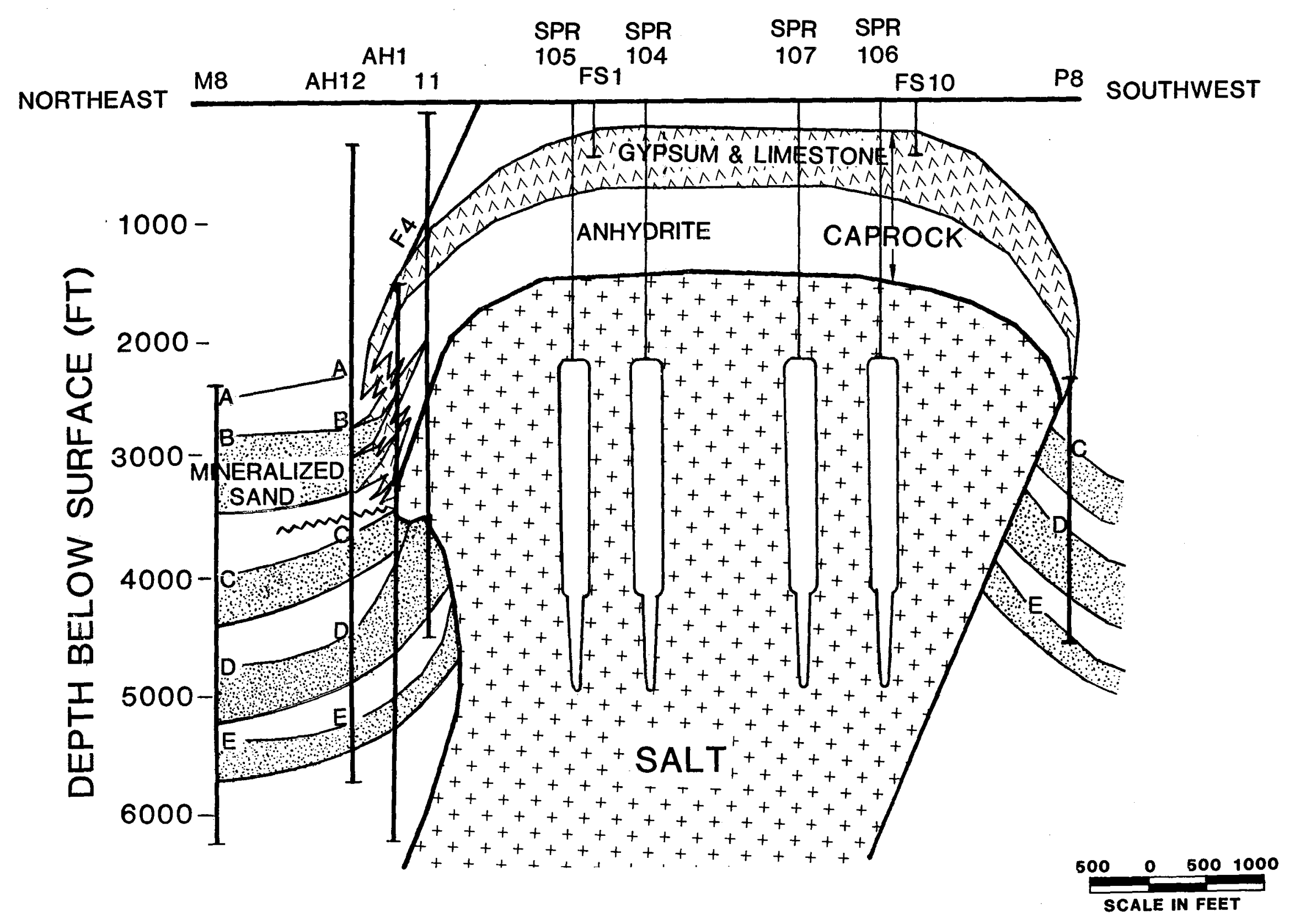

BIG HILL SALT DOME NORTHWEST-SOUTHEAST CROSS SECTION

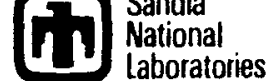




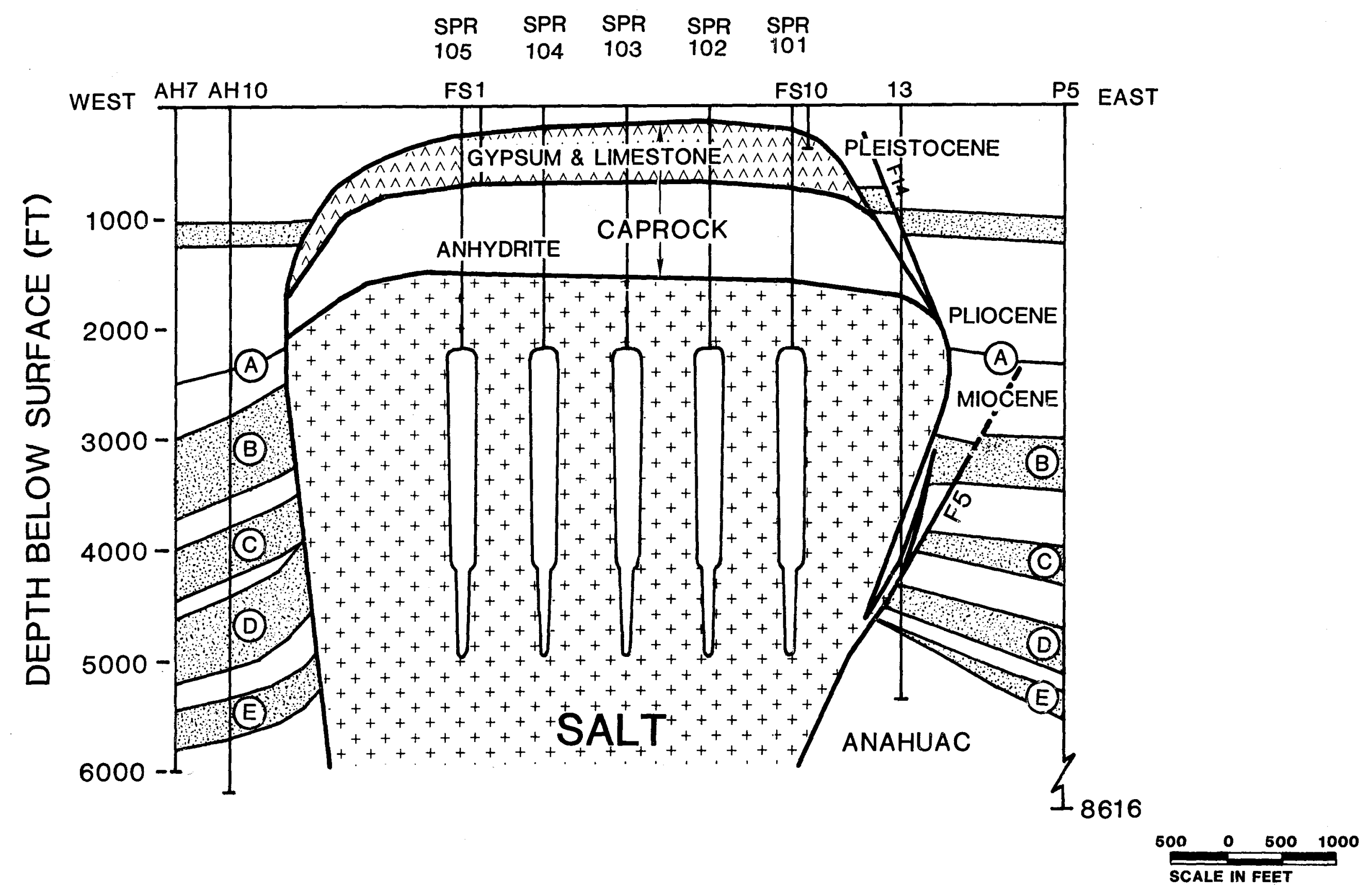

BIG HILL SALT DOME WEST-EAST CROSS SECTION NO. 1

(ii) Santianal 


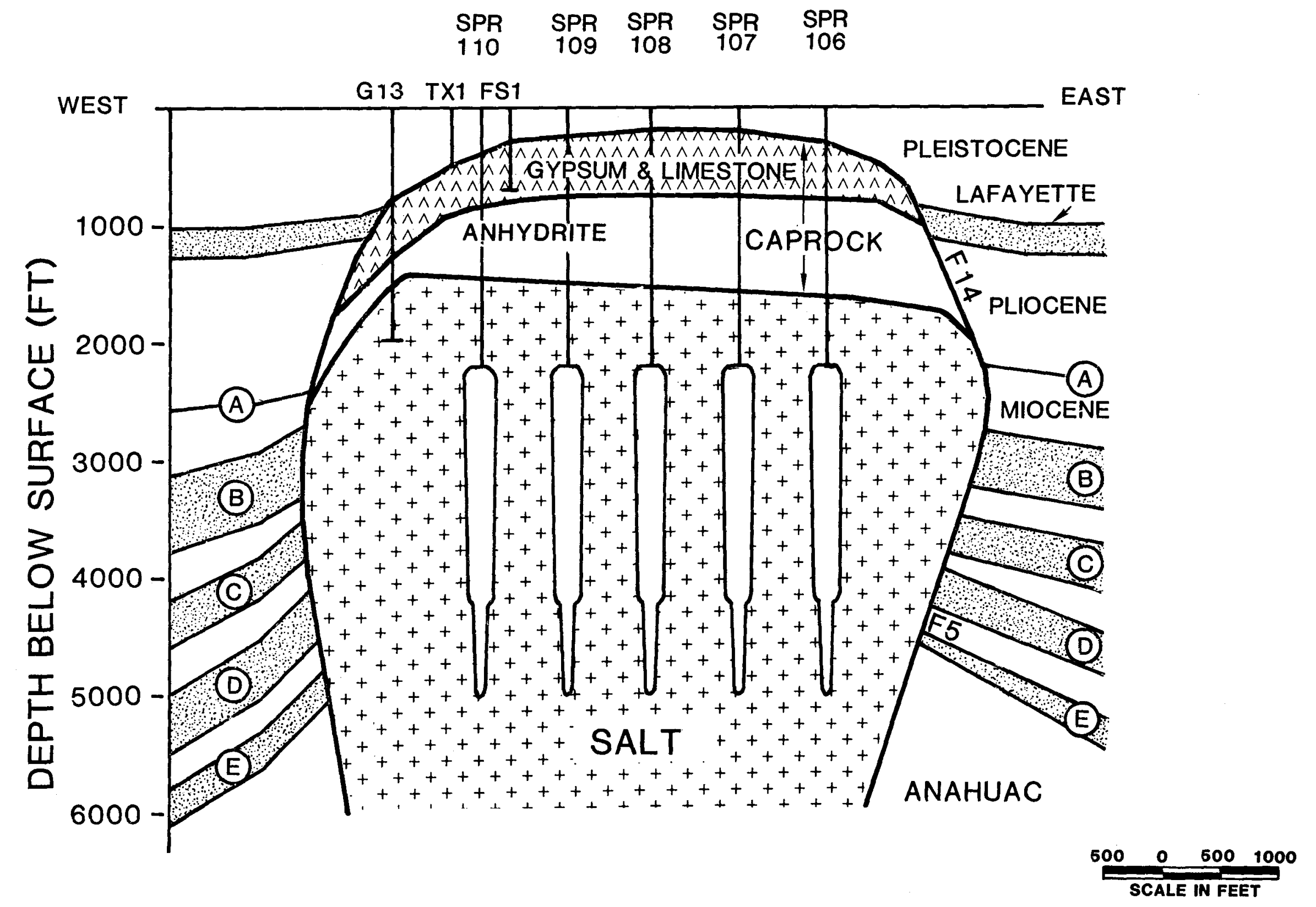

BIG HILL SALT DOME WEST-EAST CROSS SECTION NO.2 


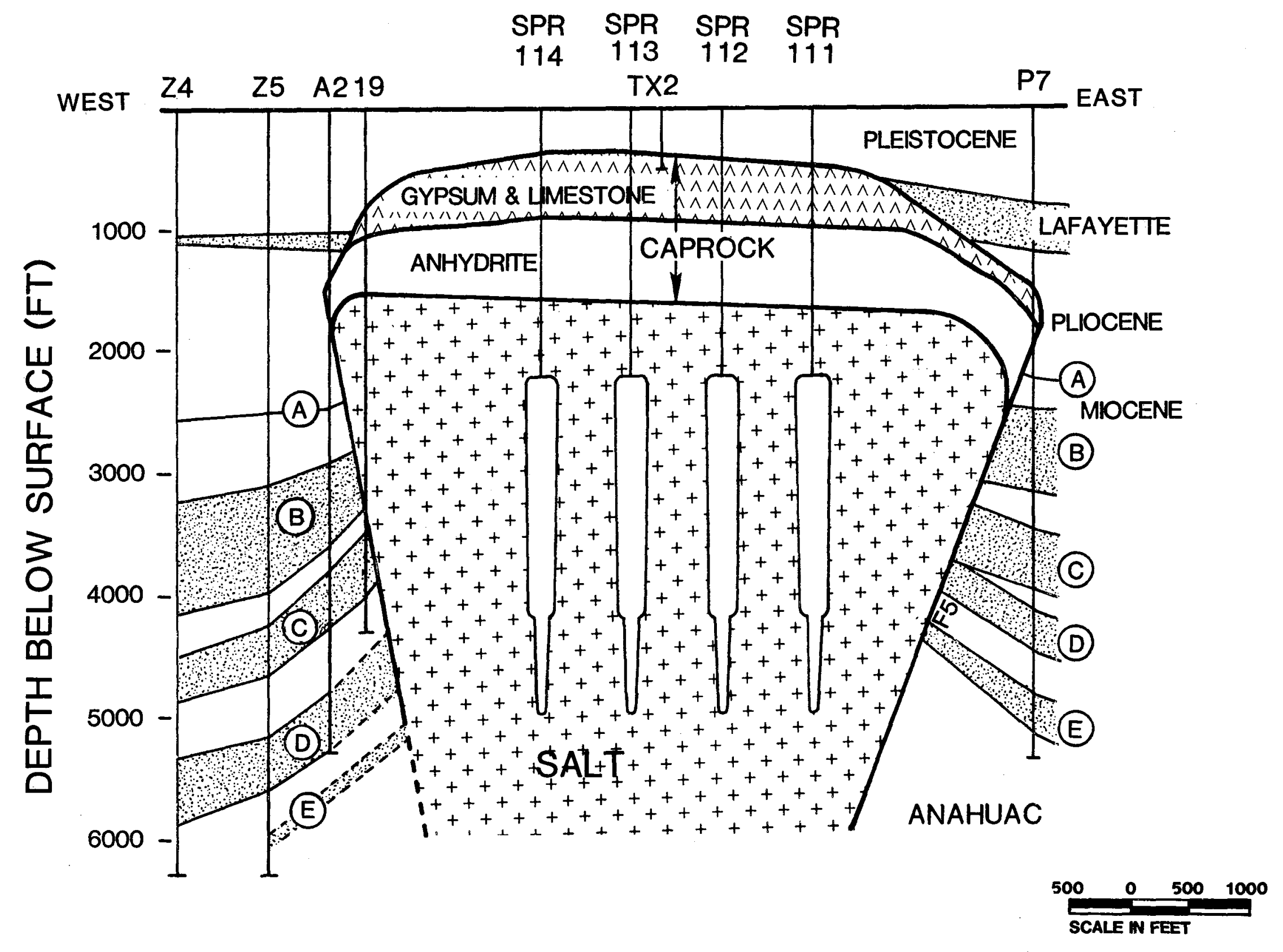

BIG HILL SALT DOME WEST-EAST CROSS SECTION NO.3 


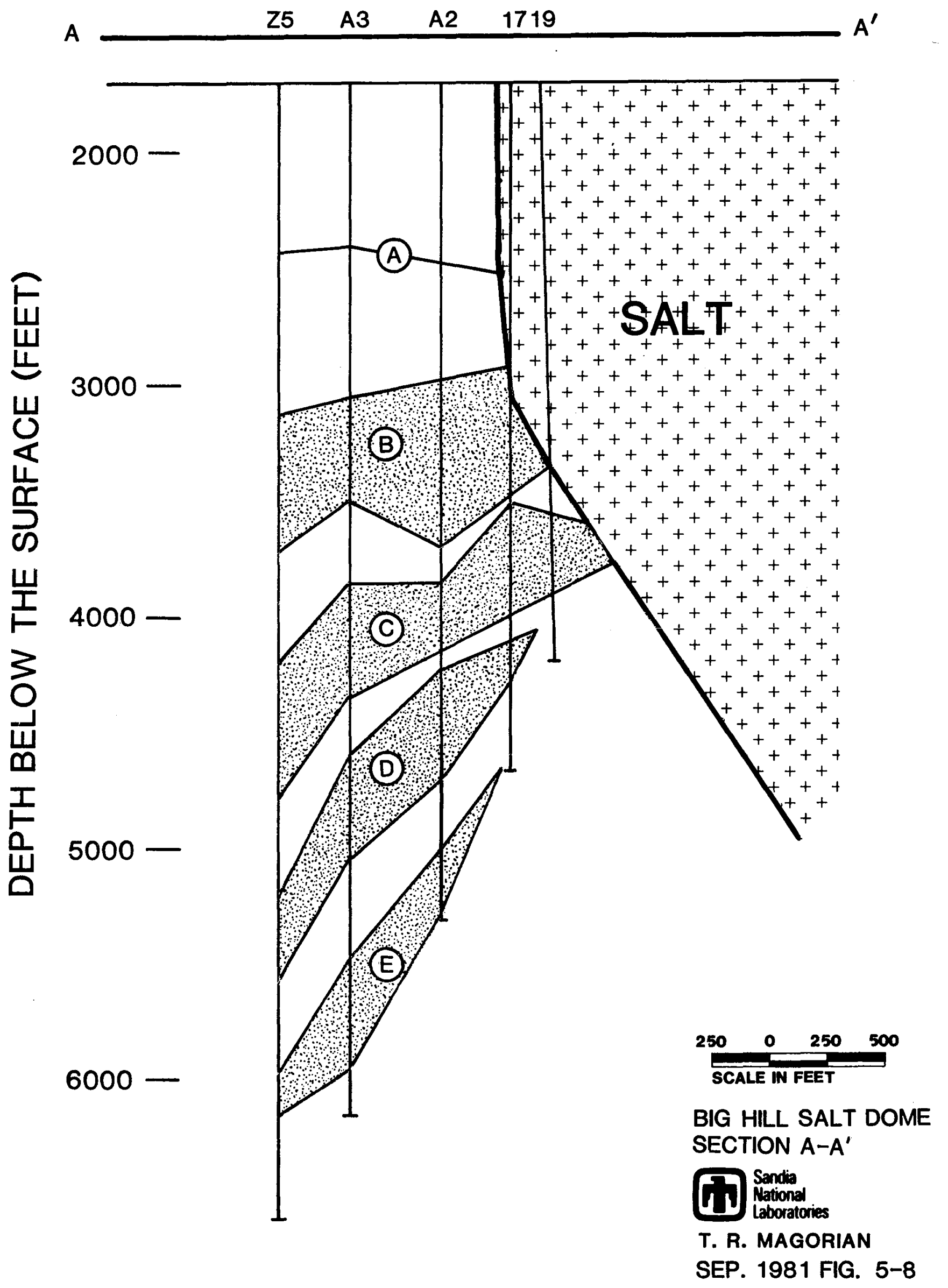




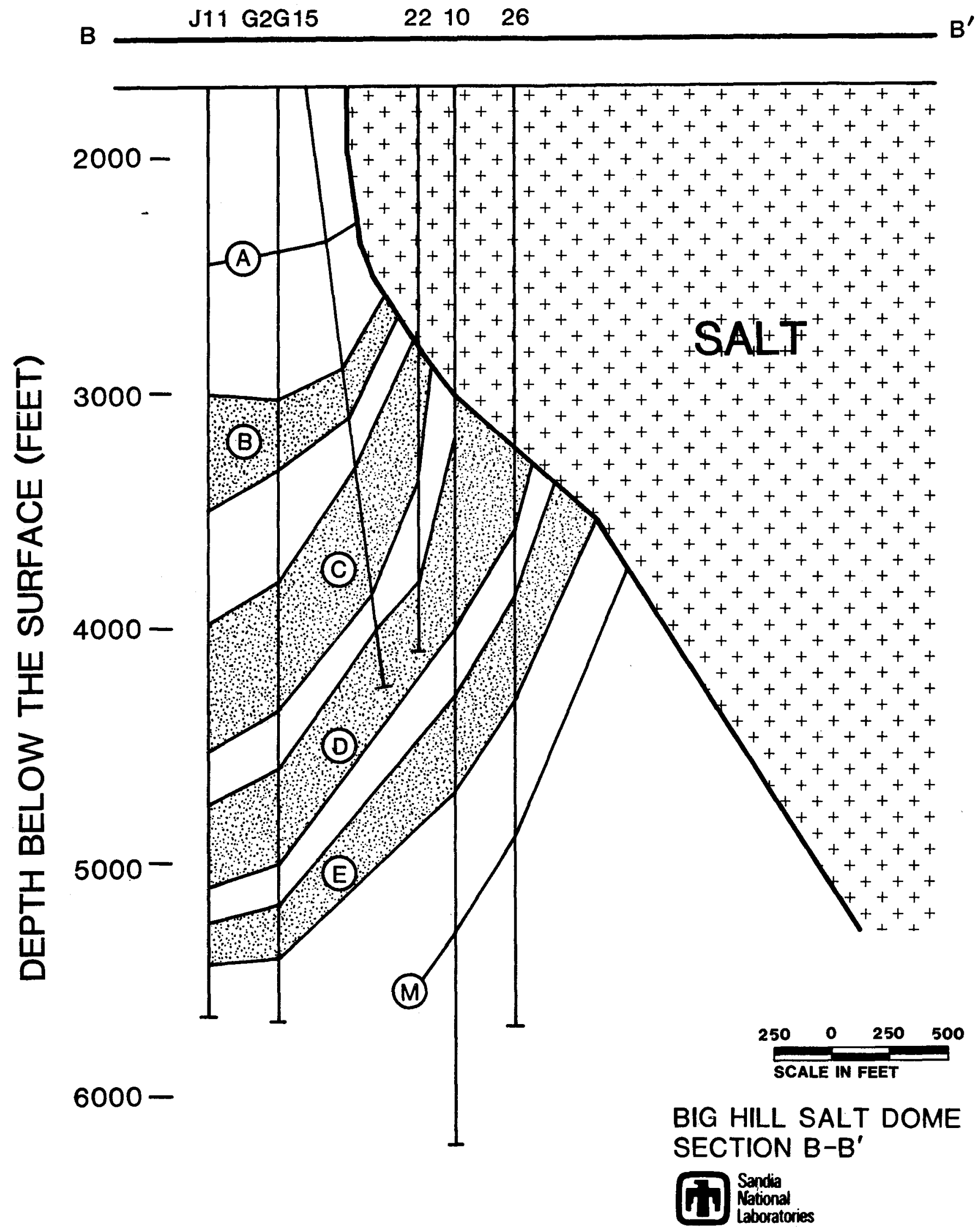

T. R. MAGORIAN

SEP. 1981 FIG. 5-9 


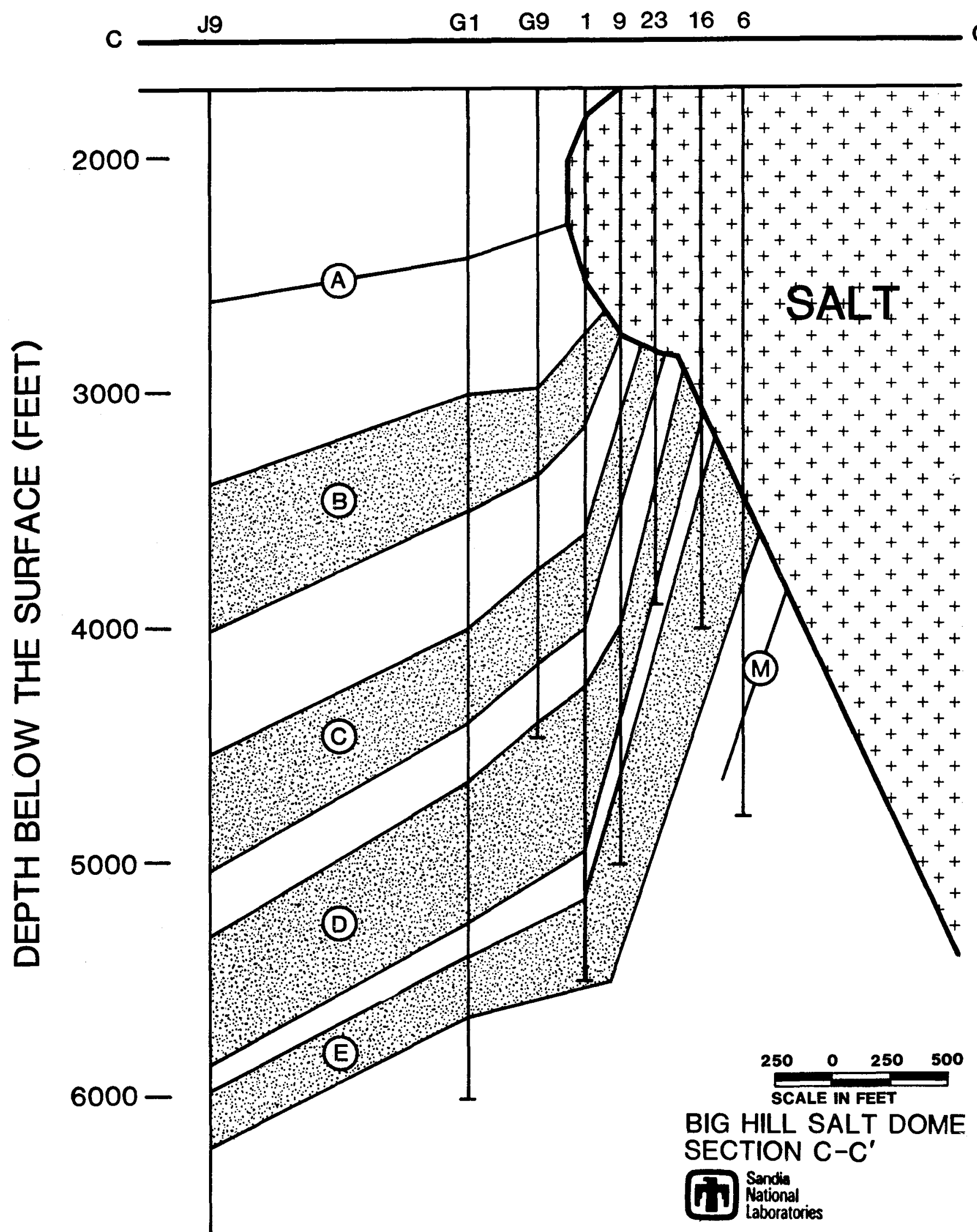

T. R. MAGORIAN

SEP 1981 FIG. 5-10 


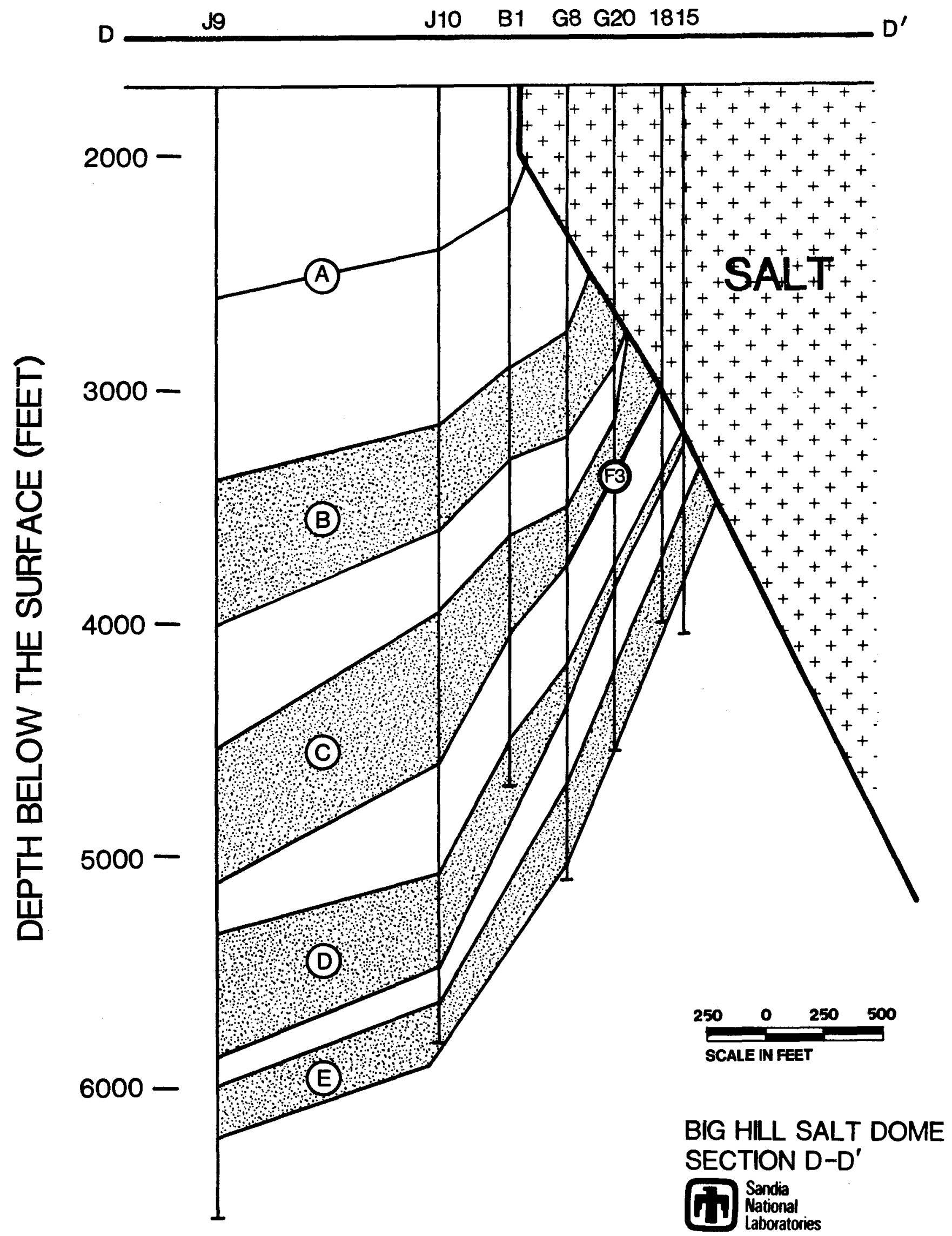

T.R. MAGORIAN

SEP. 1981 FIG. 5-11 

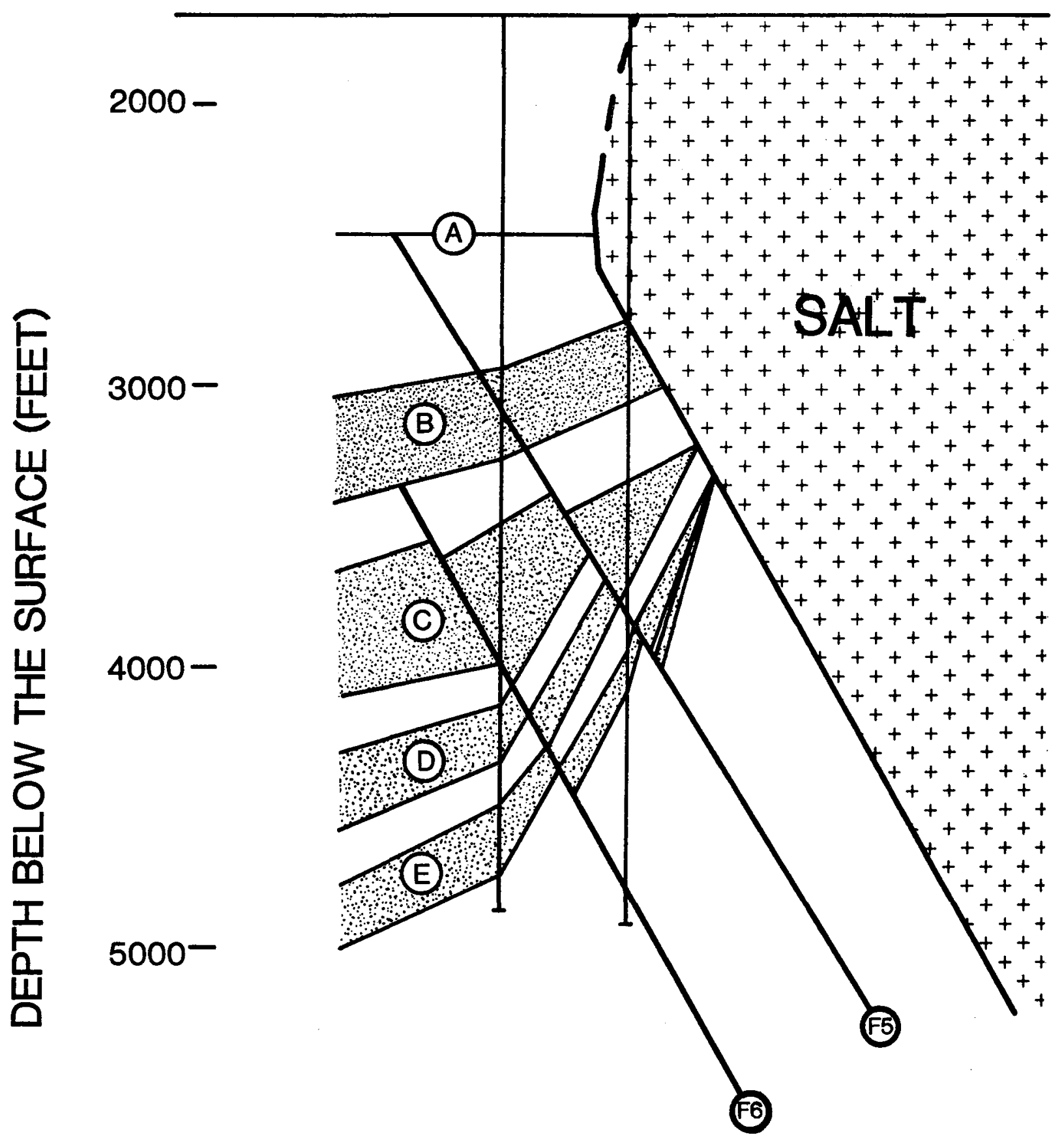

$6000-$

$\begin{array}{llll}250 \quad 0 & 0 & 250 & 500 \\ \text { SCALE N FEET } & \end{array}$

BIG HILL SALT DOME SECTION E-E' 


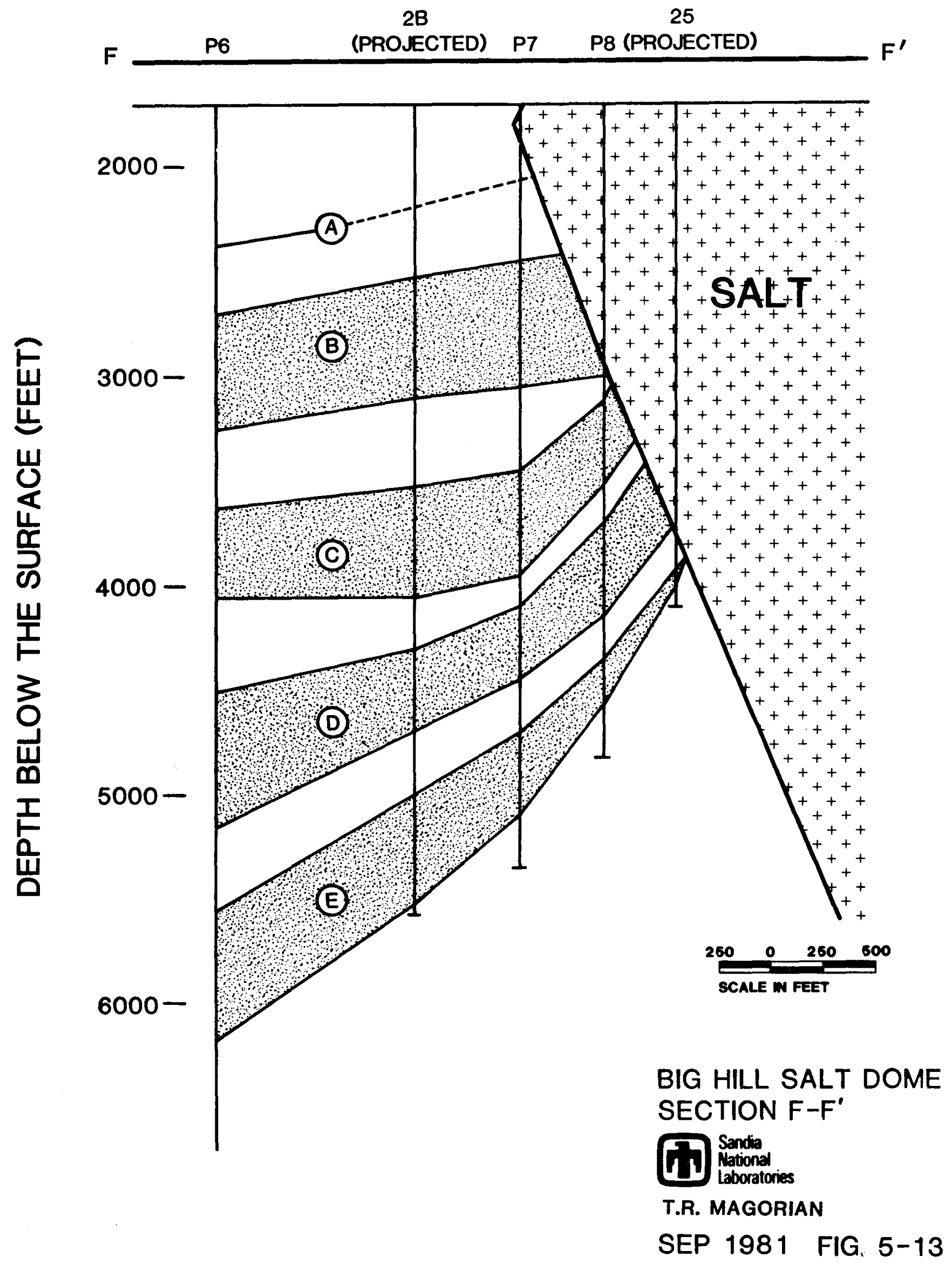




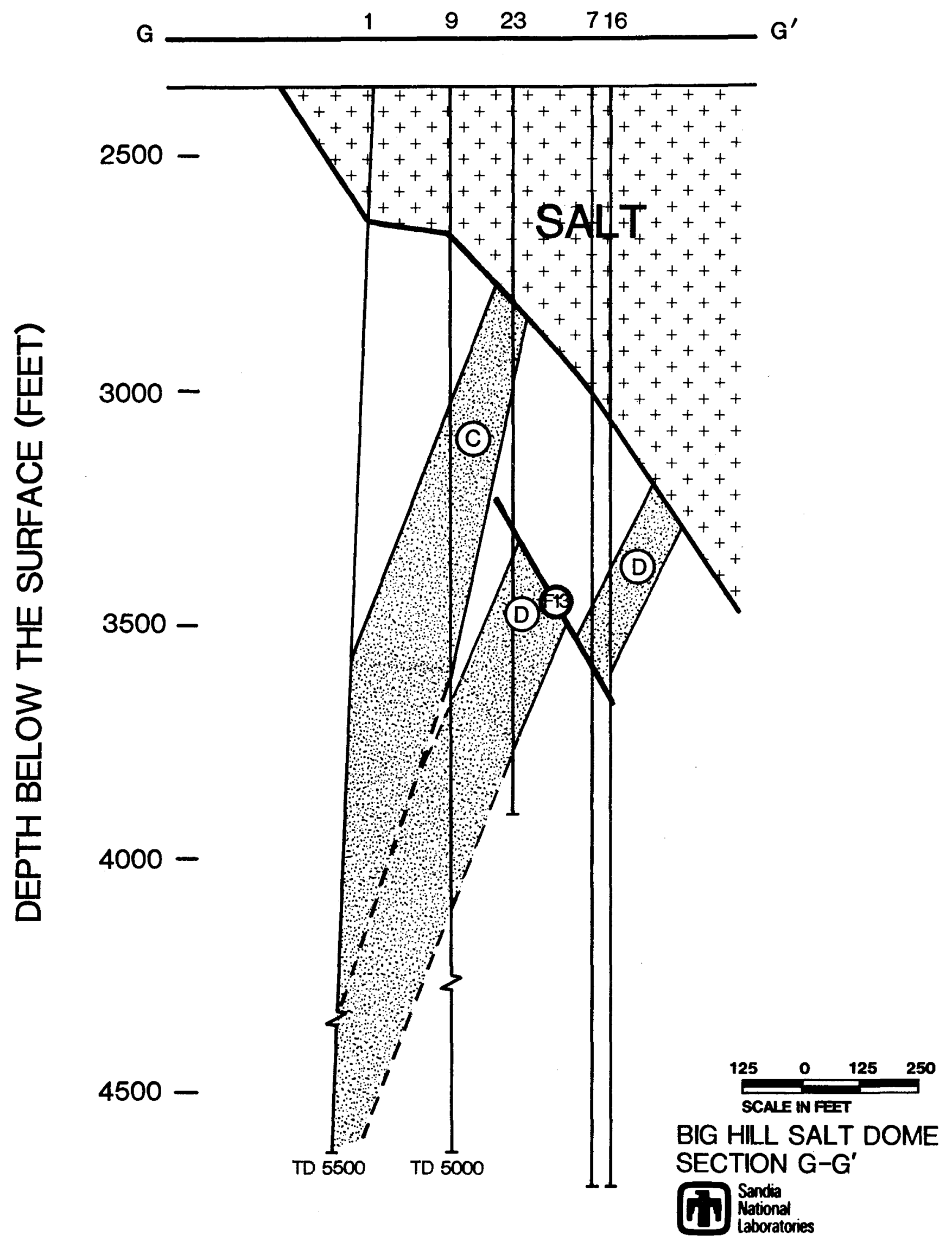

T. R. MAGORIAN

SEP 1981 FIG. 5-14 


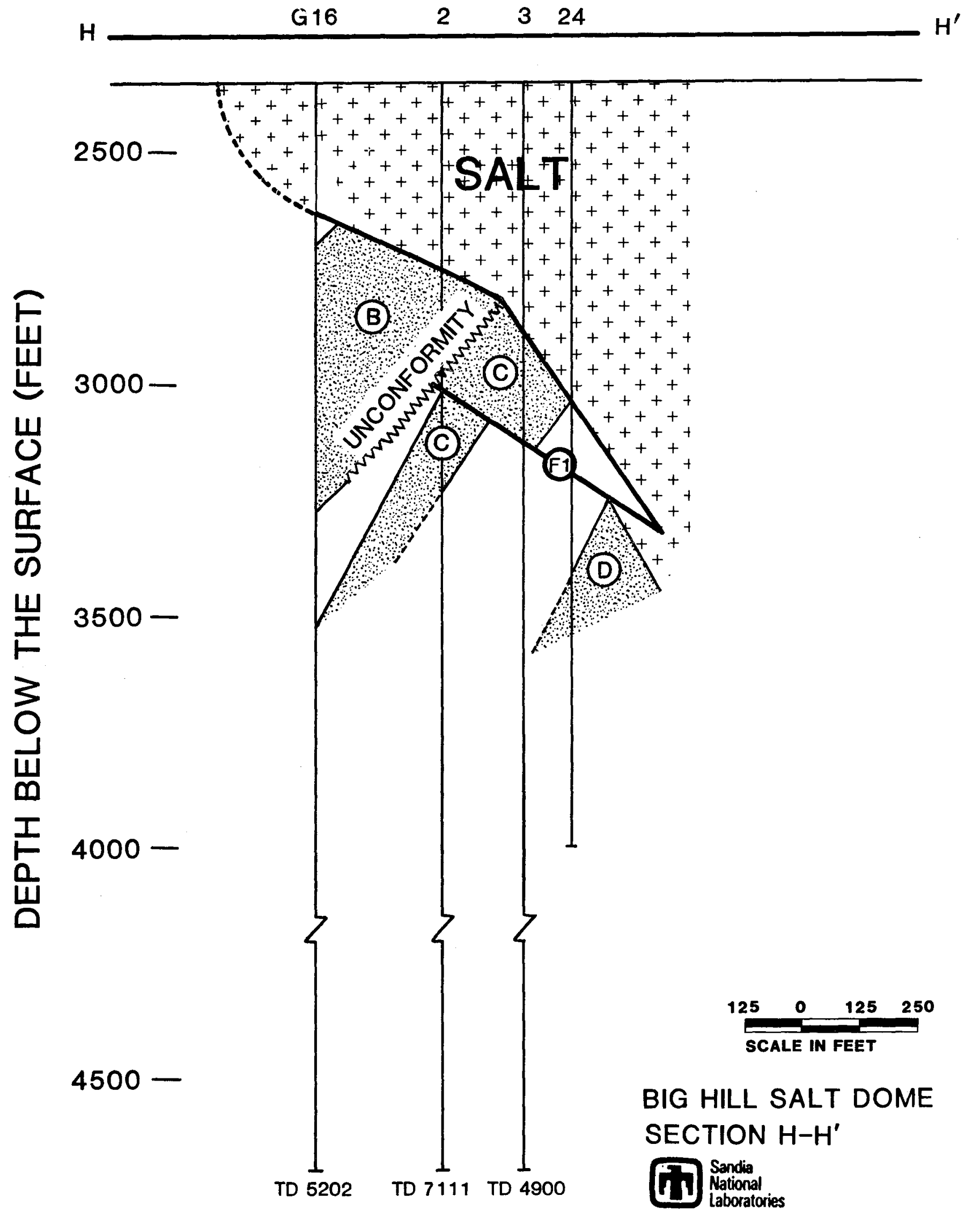

T. R. MAGORIAN

SEP. 1981 FIG. 5-15 


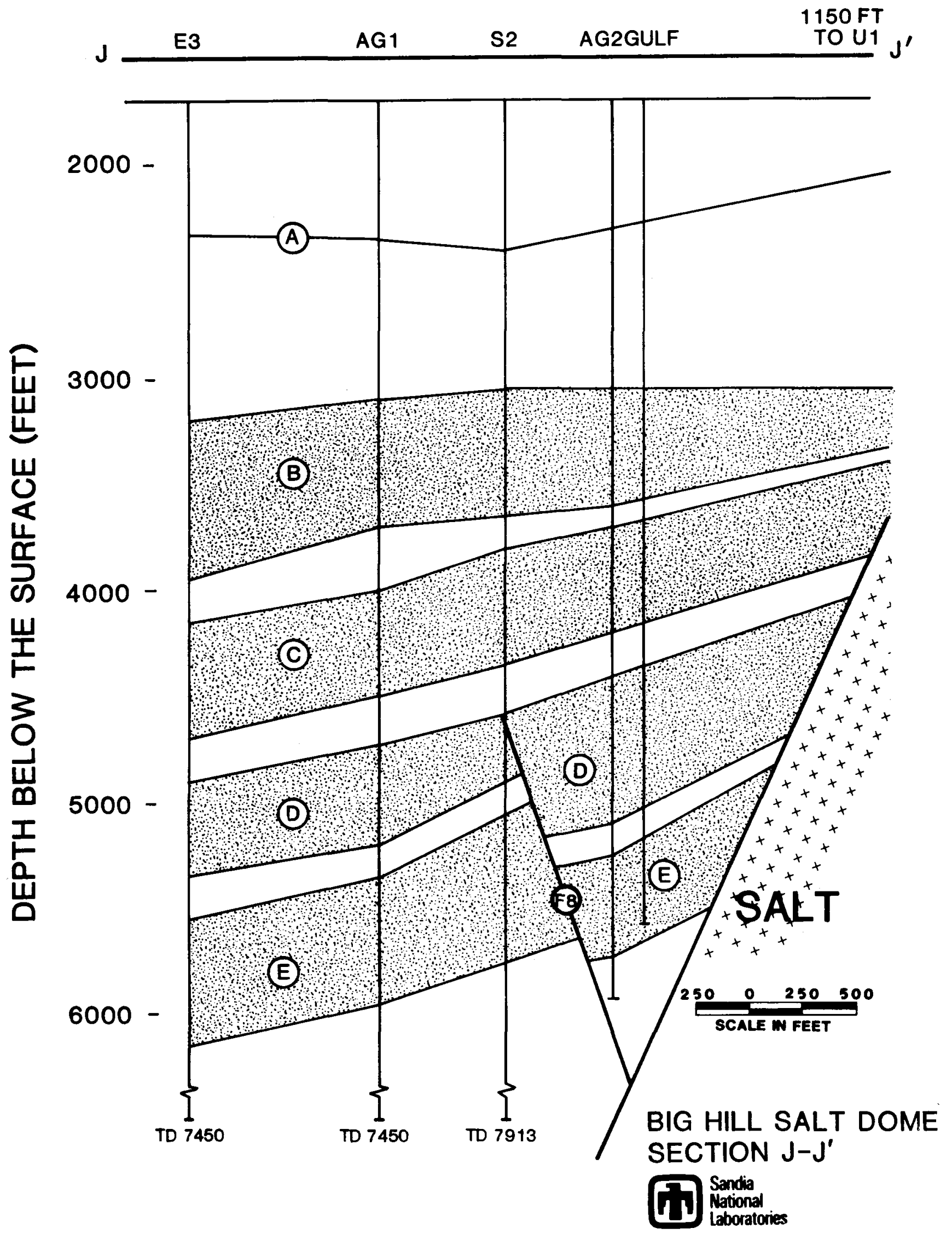

T.R. MAGORIAN

SEP. 1981 FIG.5-16 


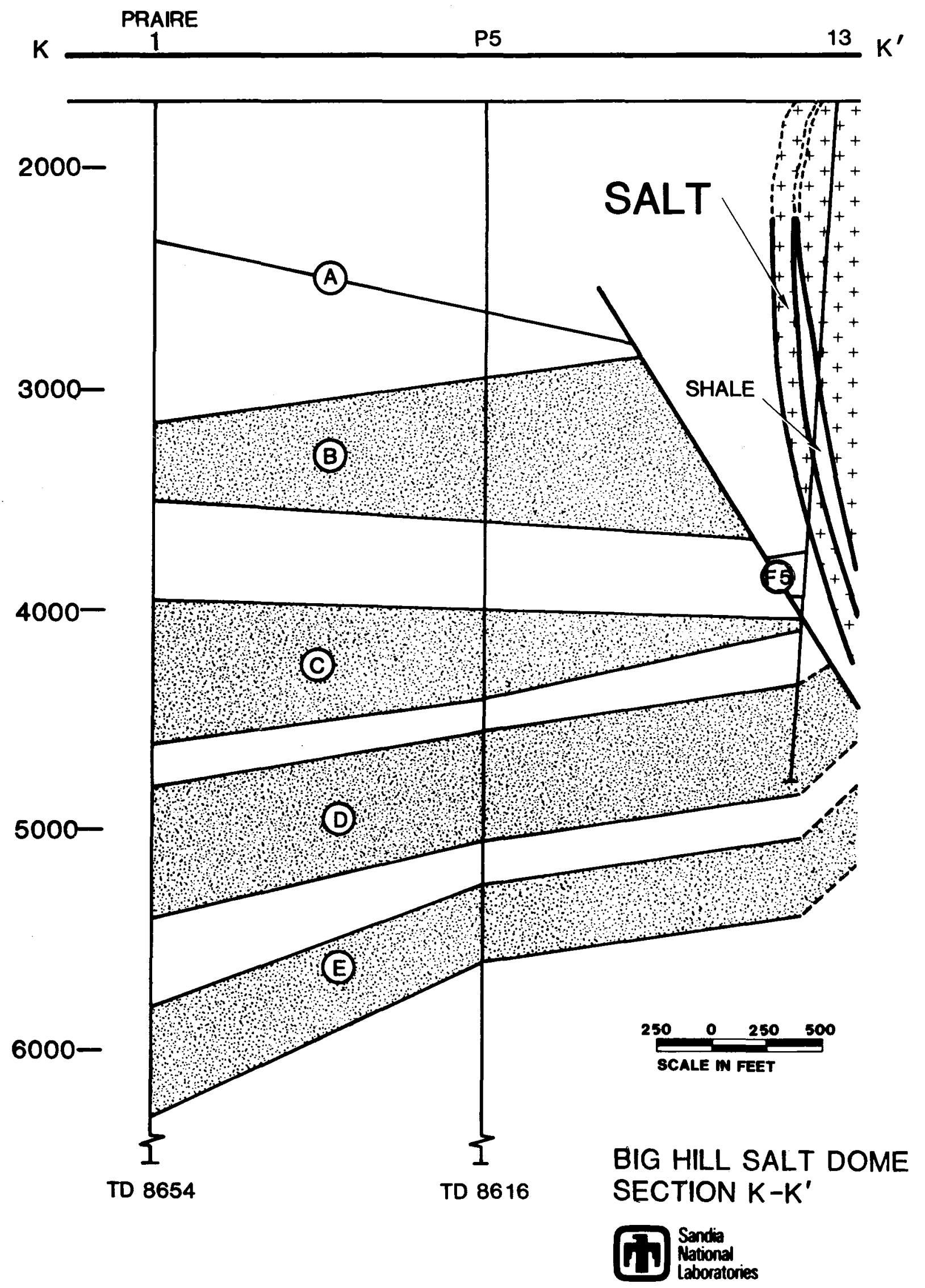

T.R. MAGORIAN
SEP. 1981 FIG. 5-17 


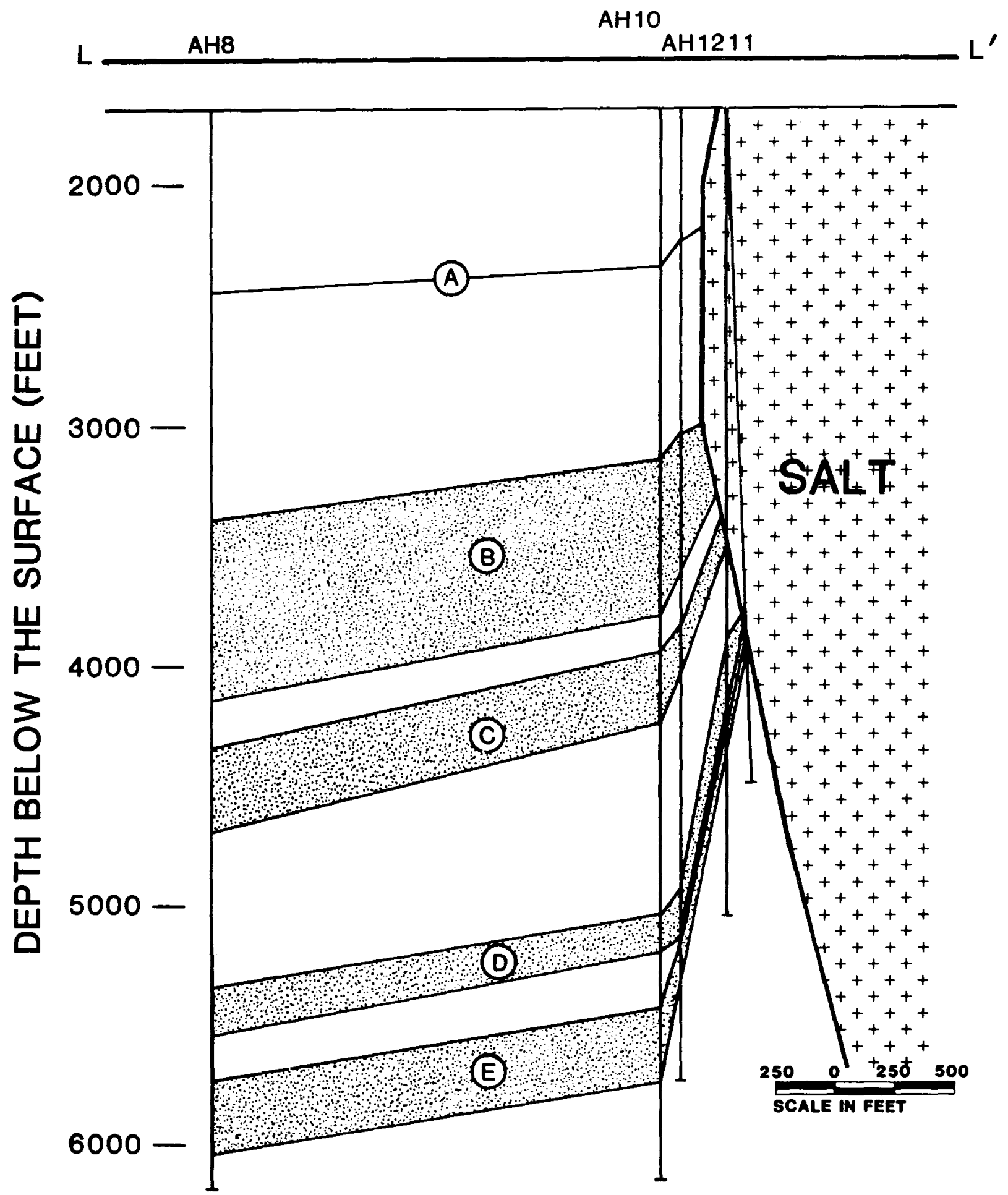

BIG HILL SALT DOME SECTION L-L'

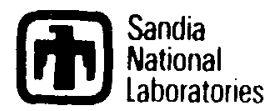




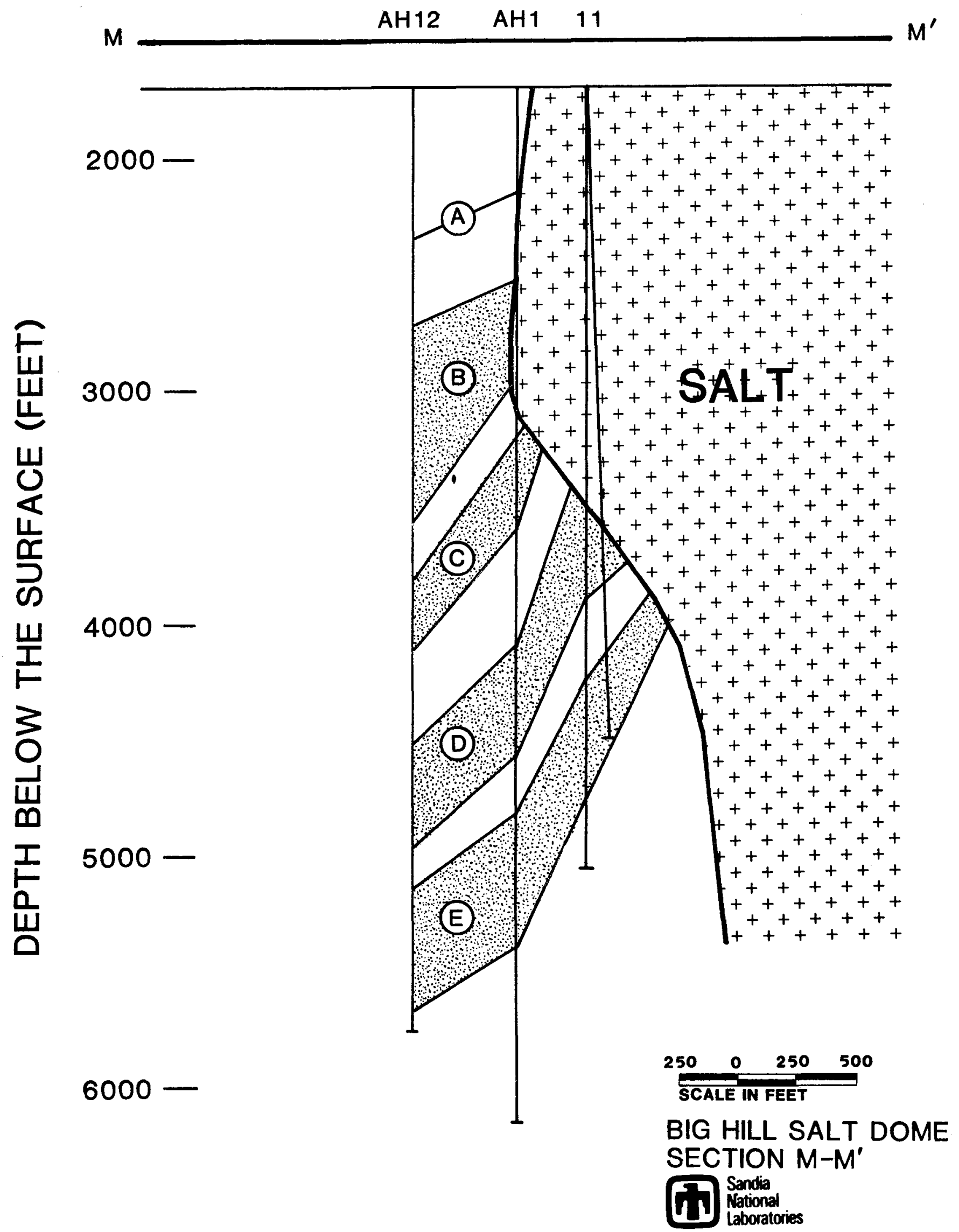

T. R. MAGORIAN

SEP. 1981 FIG. 5-19 


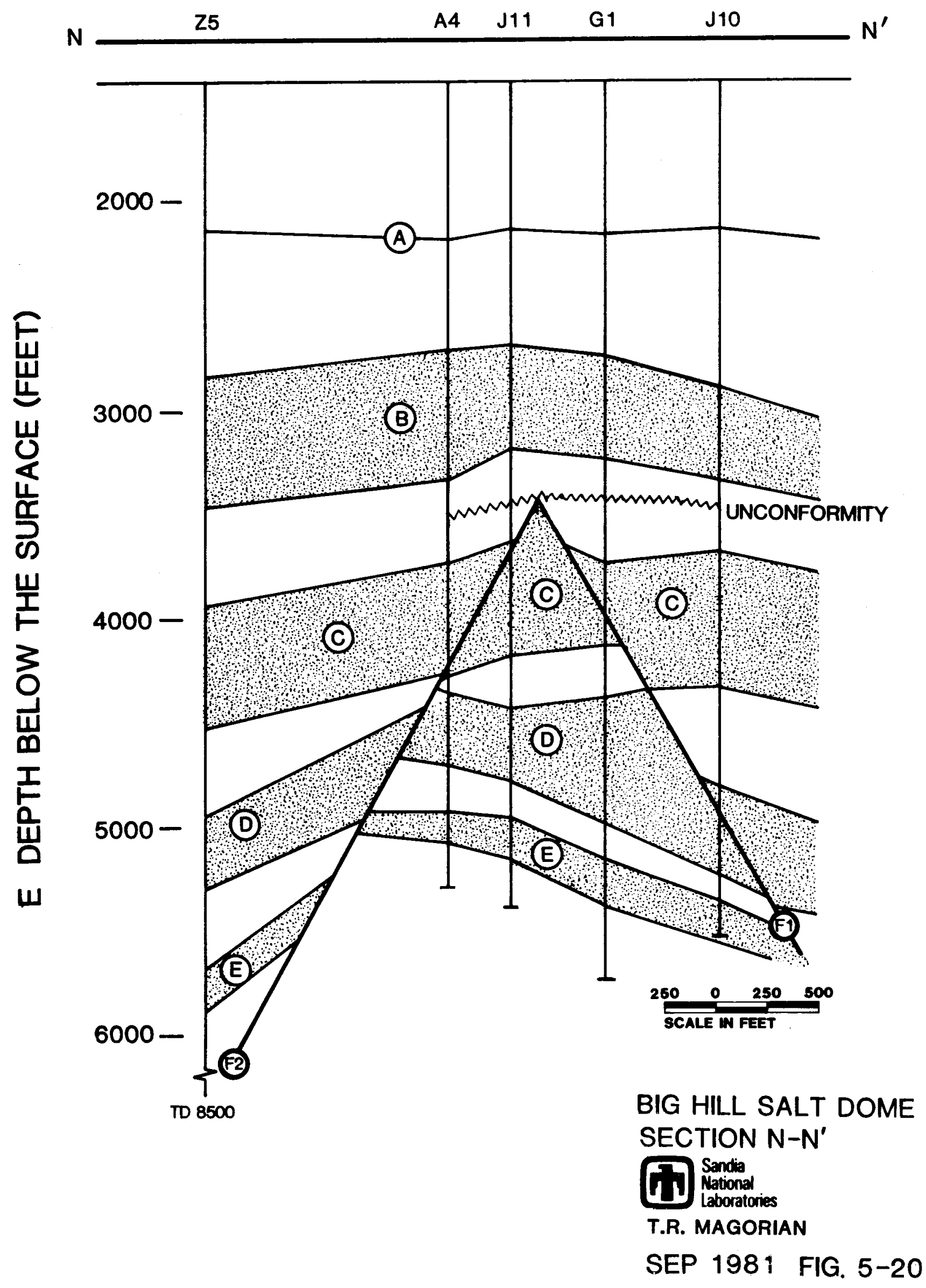




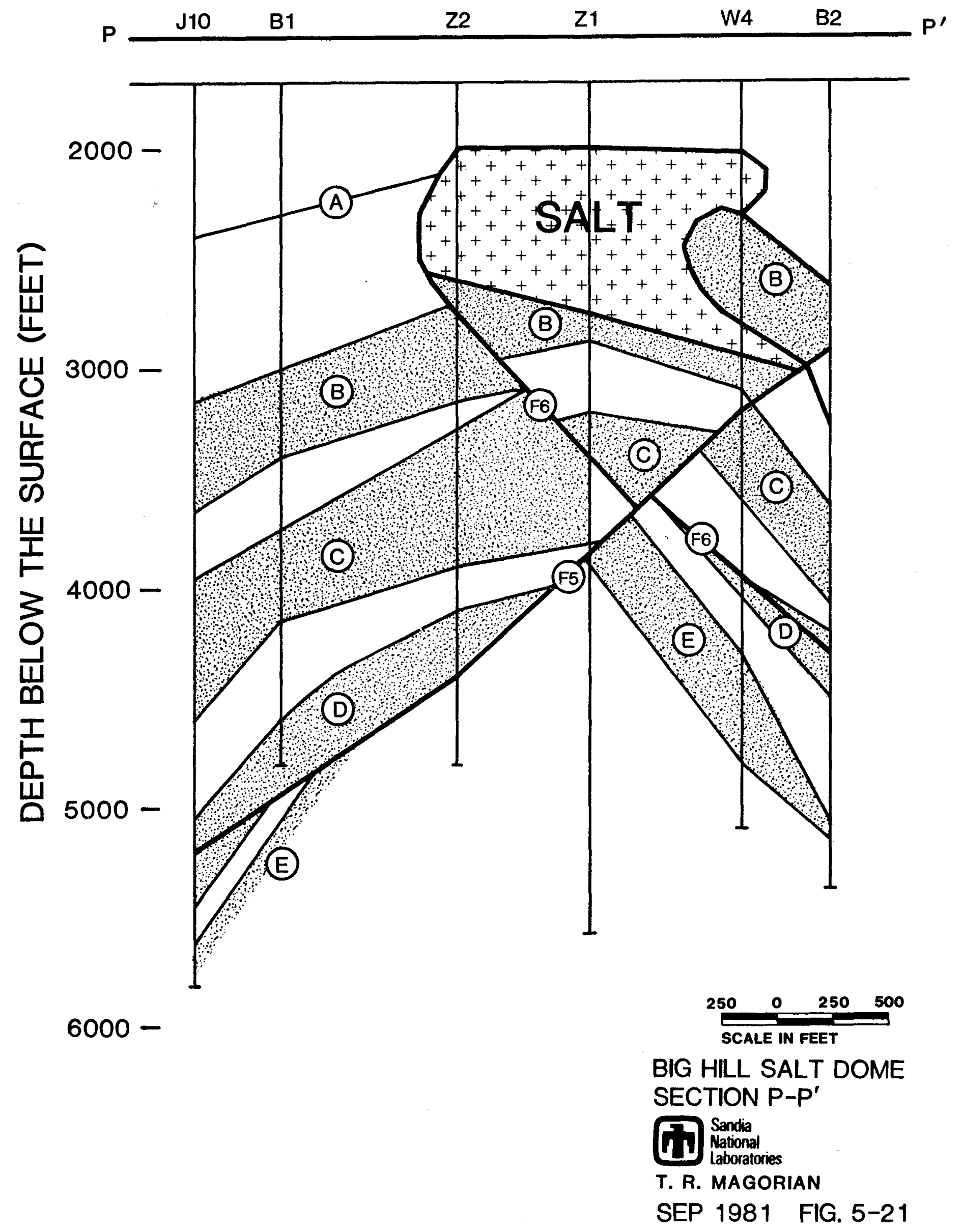




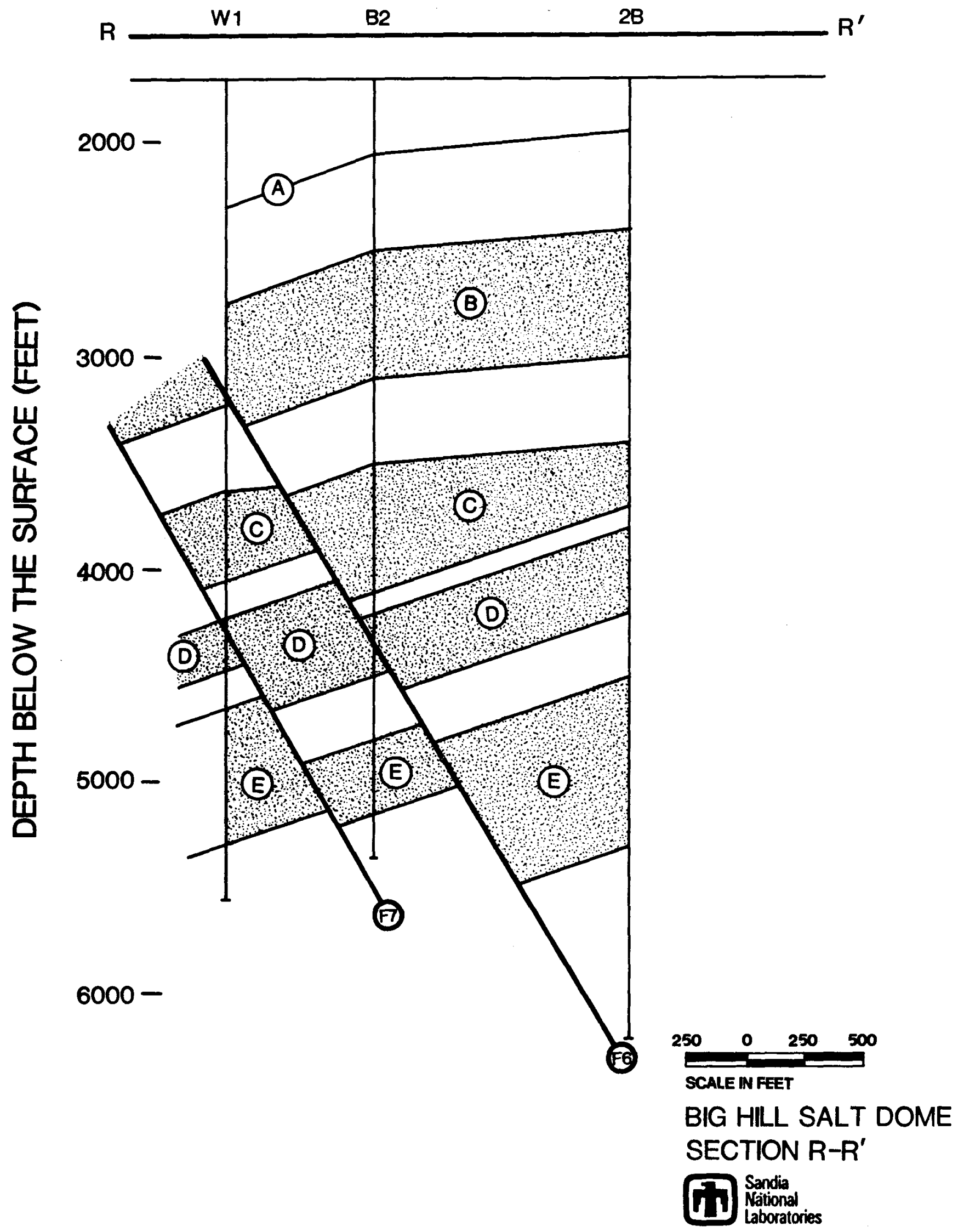

T. R. MAGORIAN

SEP 1981 FIG. 5-22 


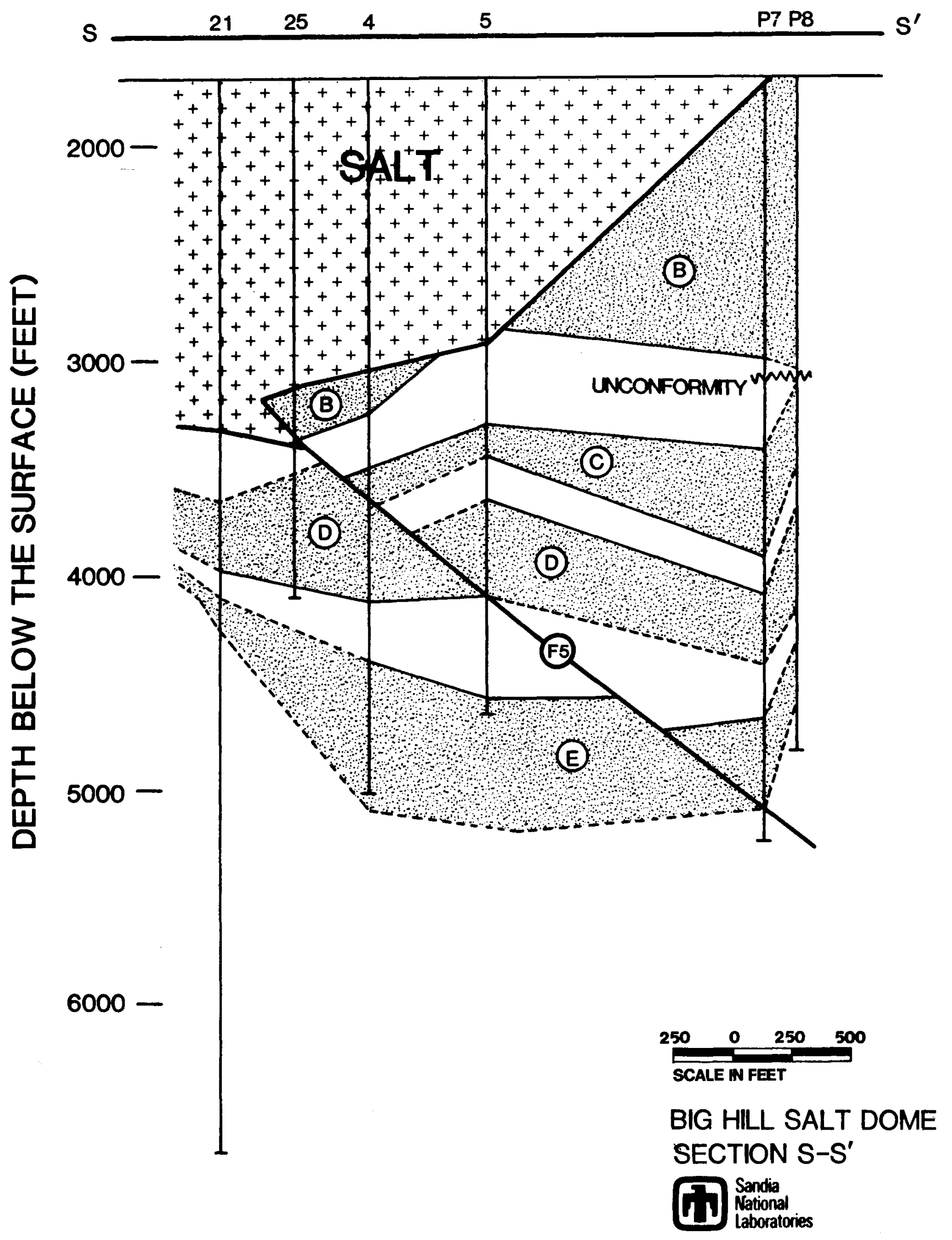

T. R. MAGORIAN

SEP. 1981 FIG. 5-23 


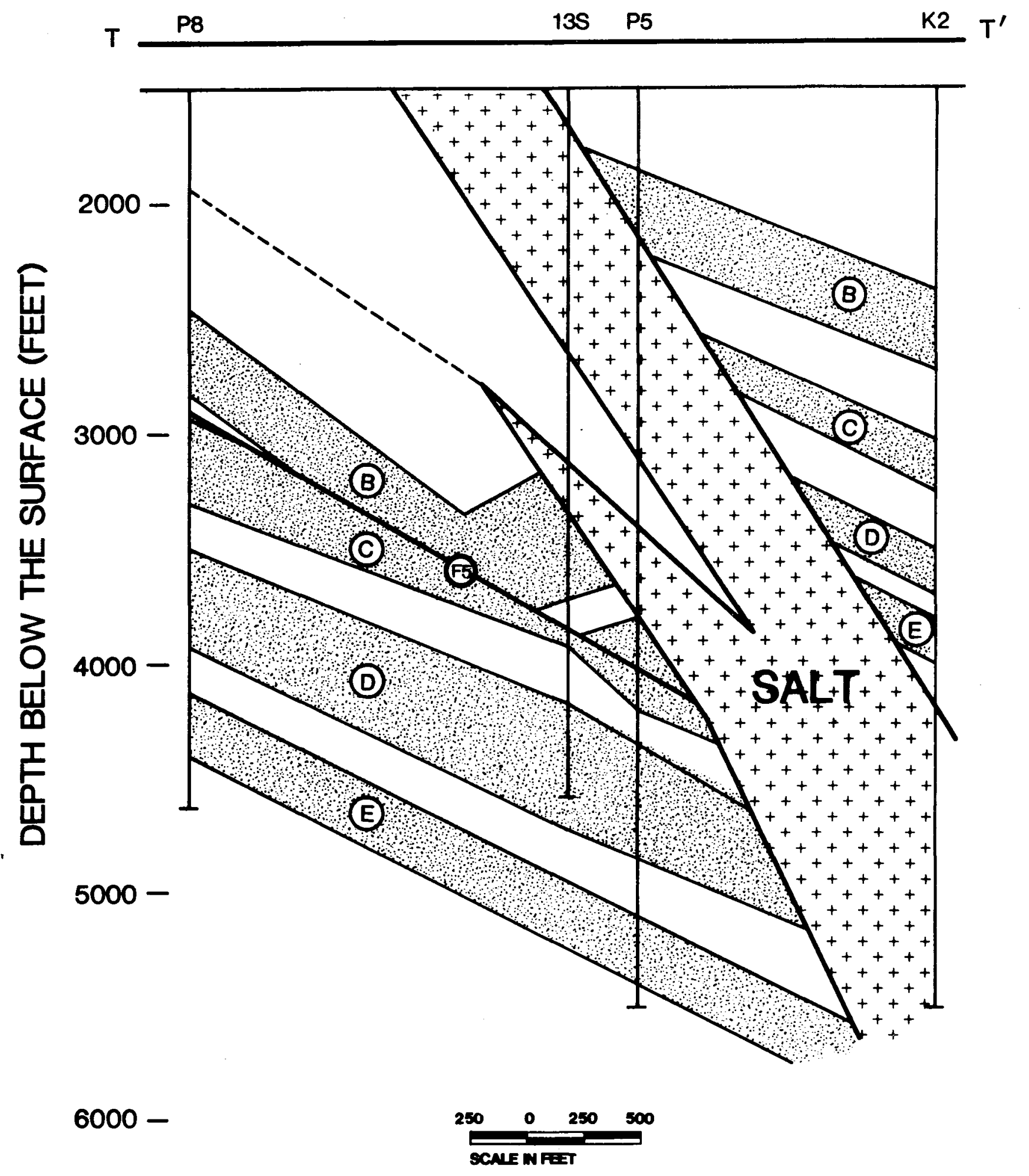

BIG HILL SALT DOME SECTION T-T' 


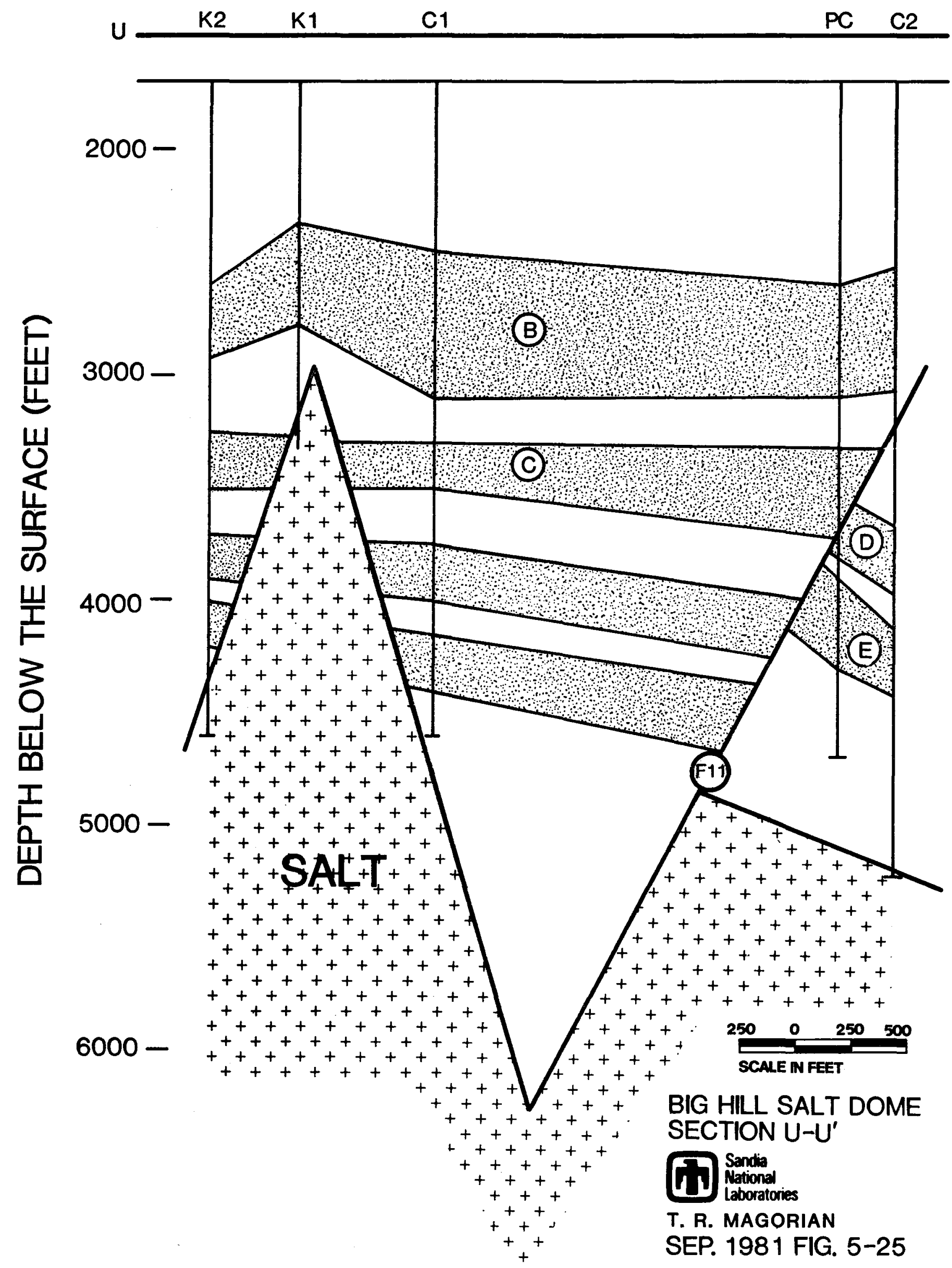




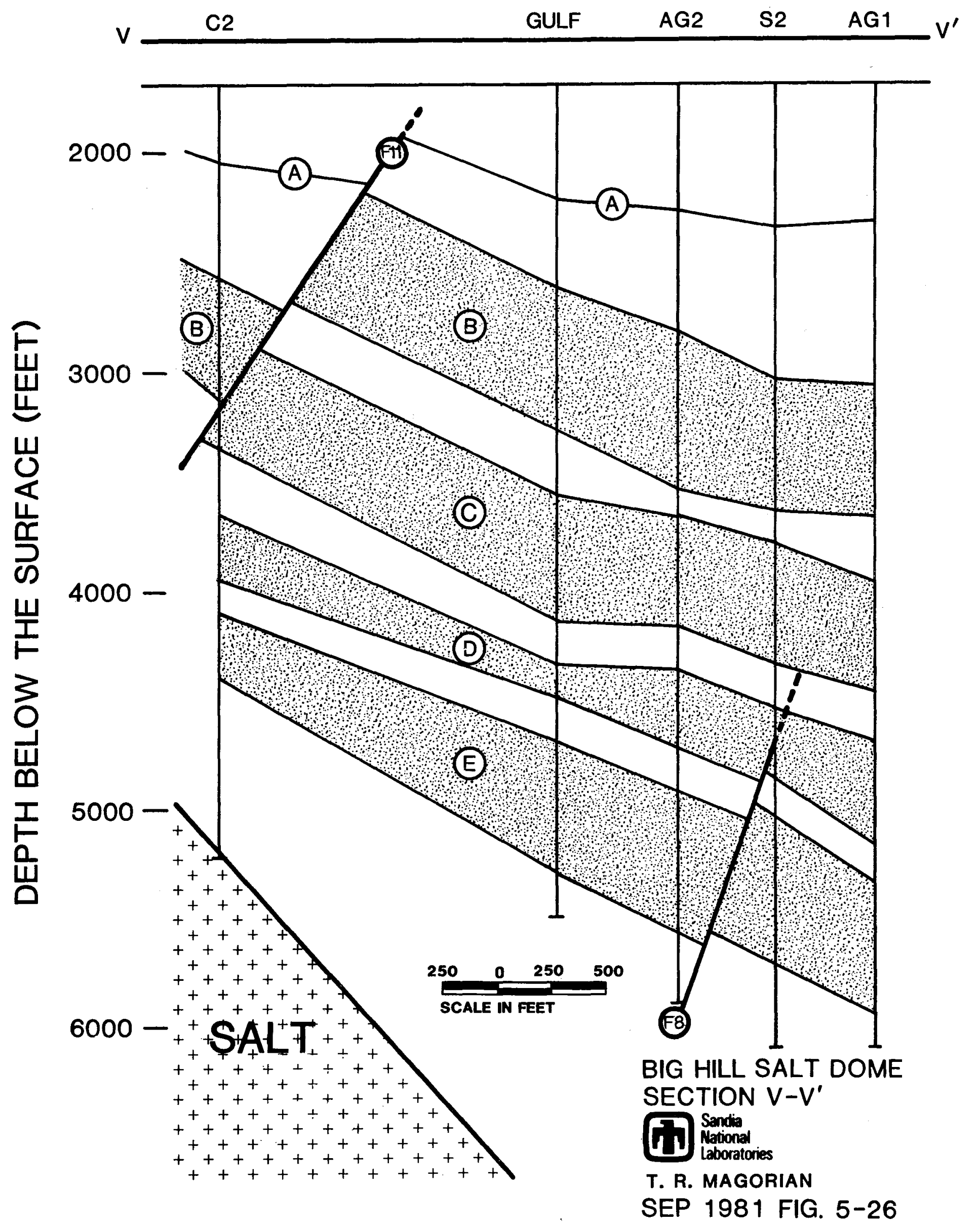




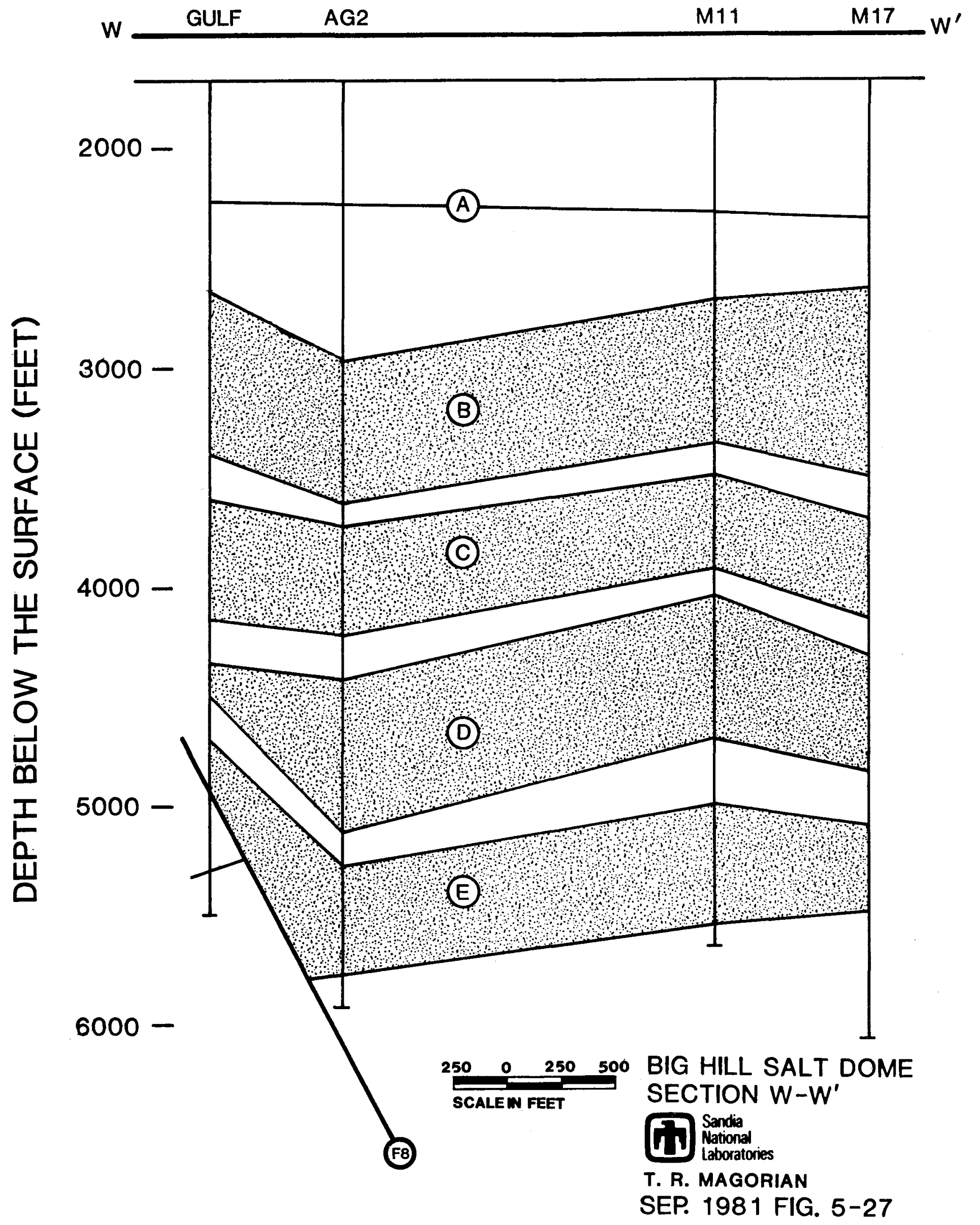




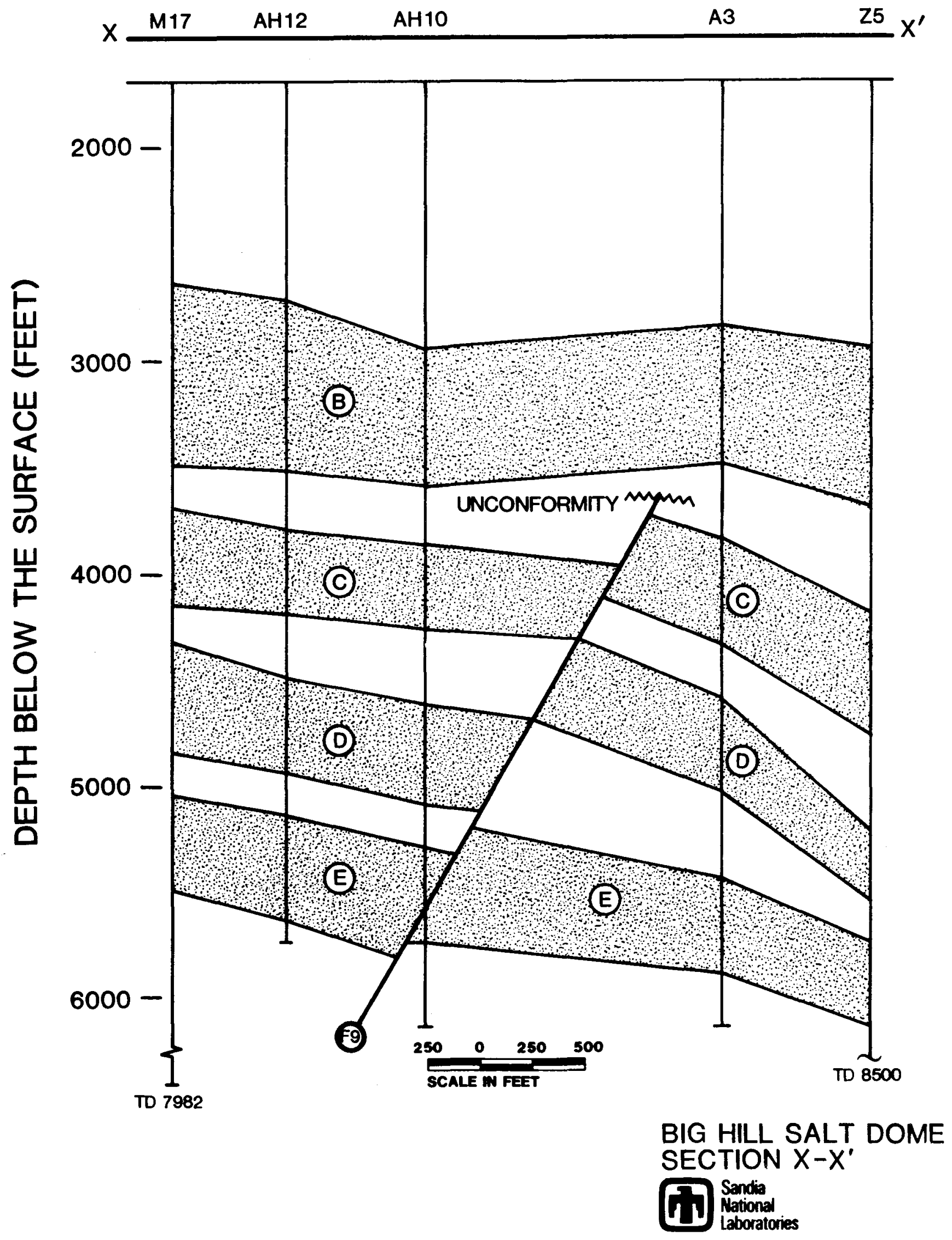

T. R. MAGORIAN

SEP 1981 FIG. 5-28 


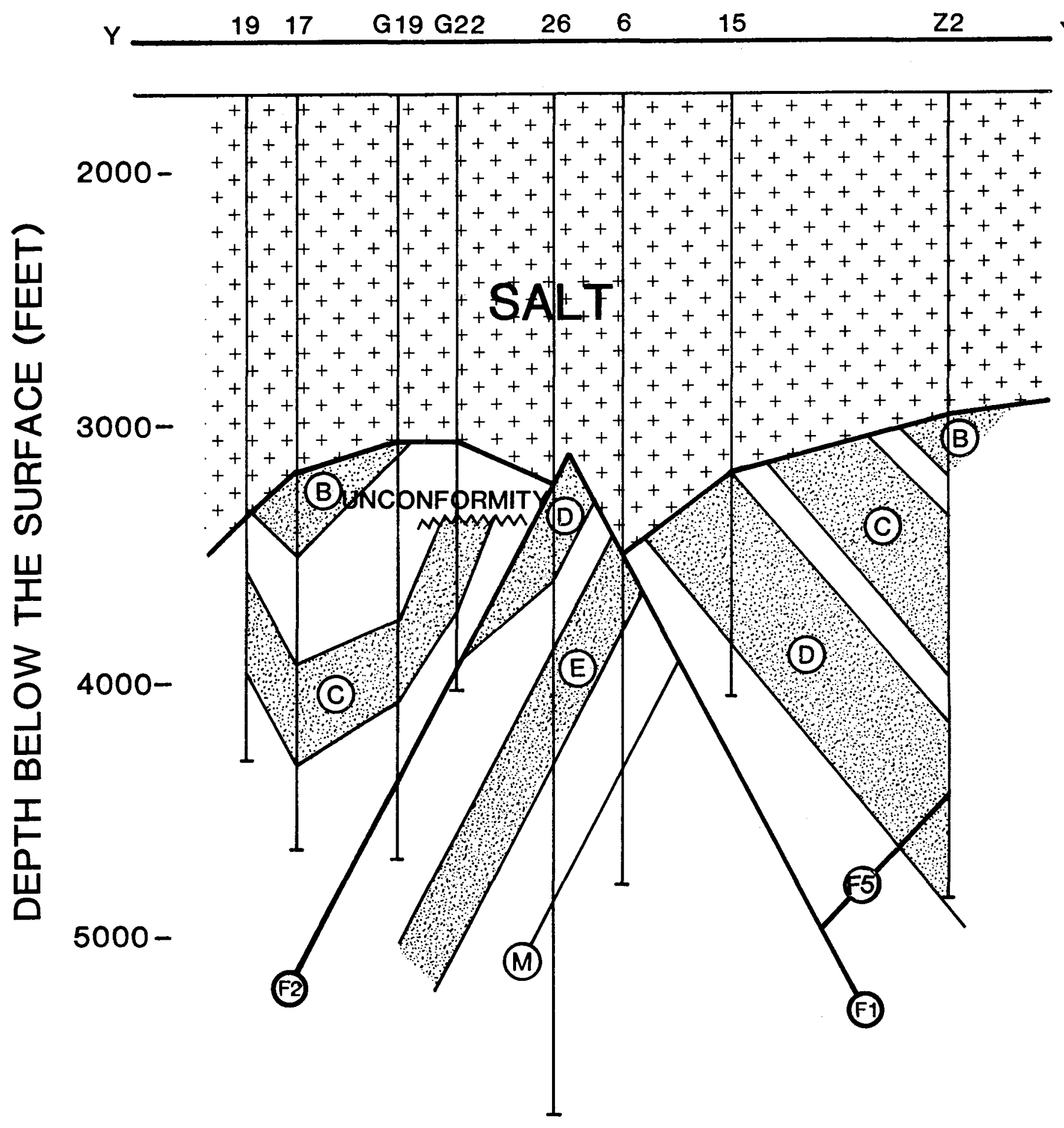

$6000-$

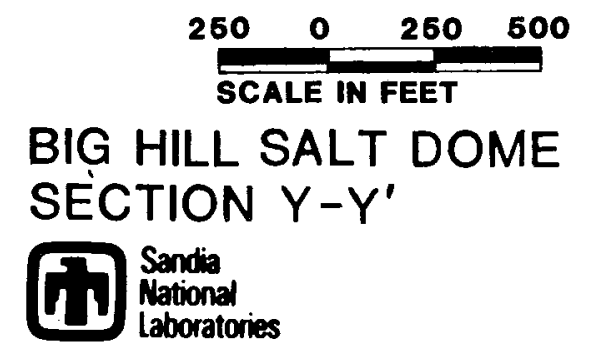

T. R. MAGORIAN

SEP 1981 FIG. 5-29 


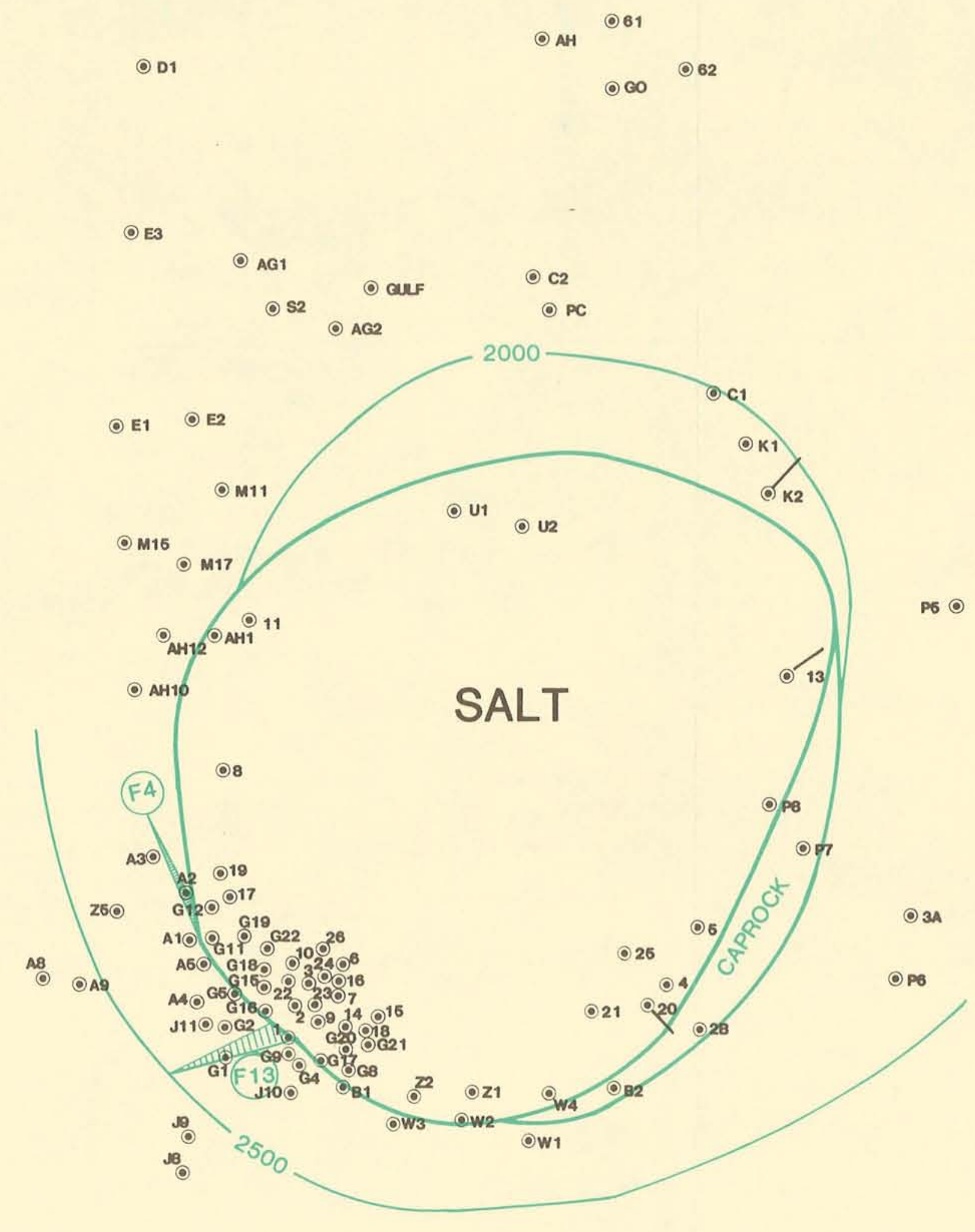

BIG HILL SALT DOME STRUCTURE MAP

A SAND

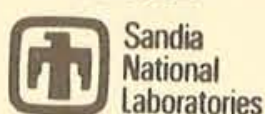

T. R. MAGORIAN

SEP 1981 FIG. 5-30 


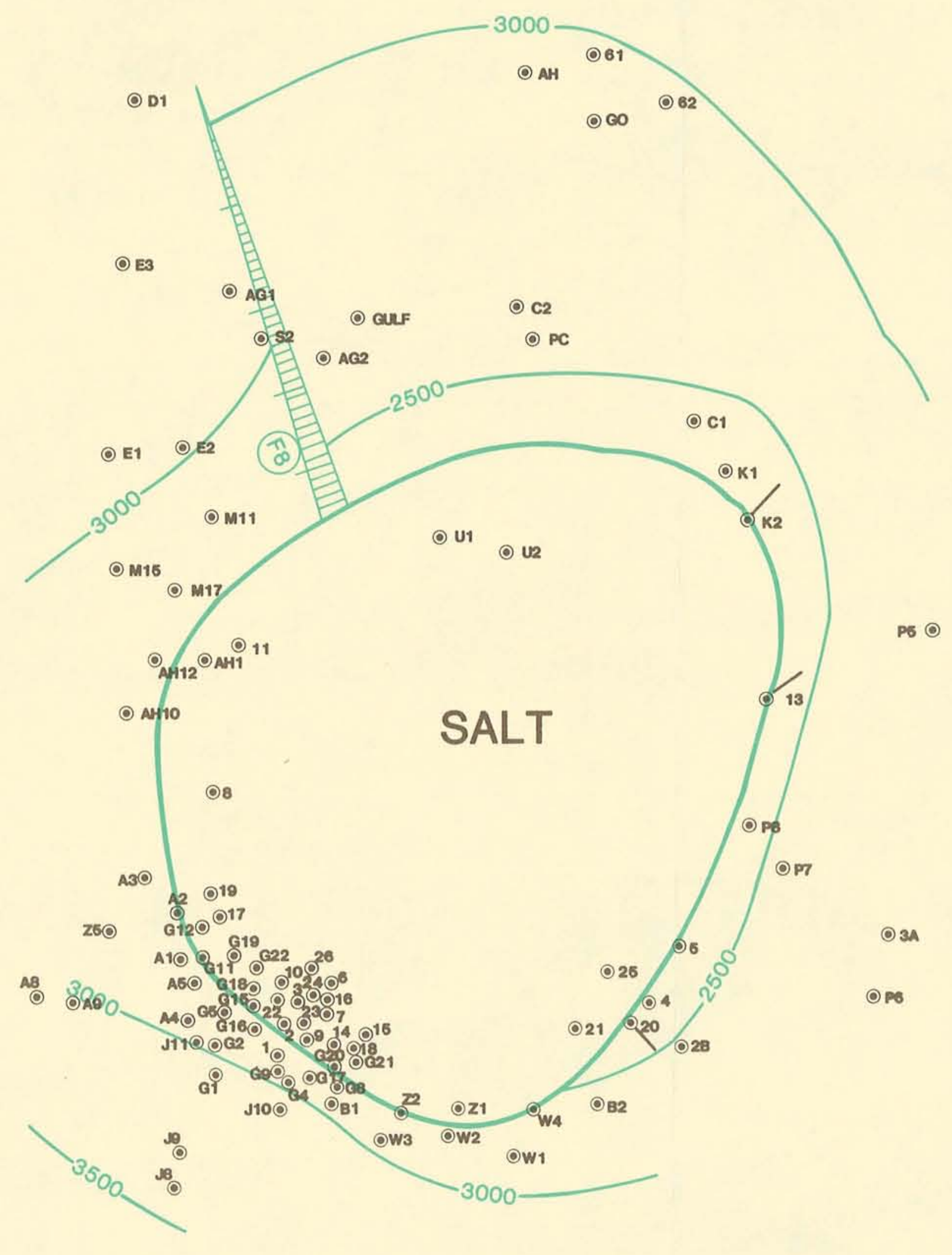



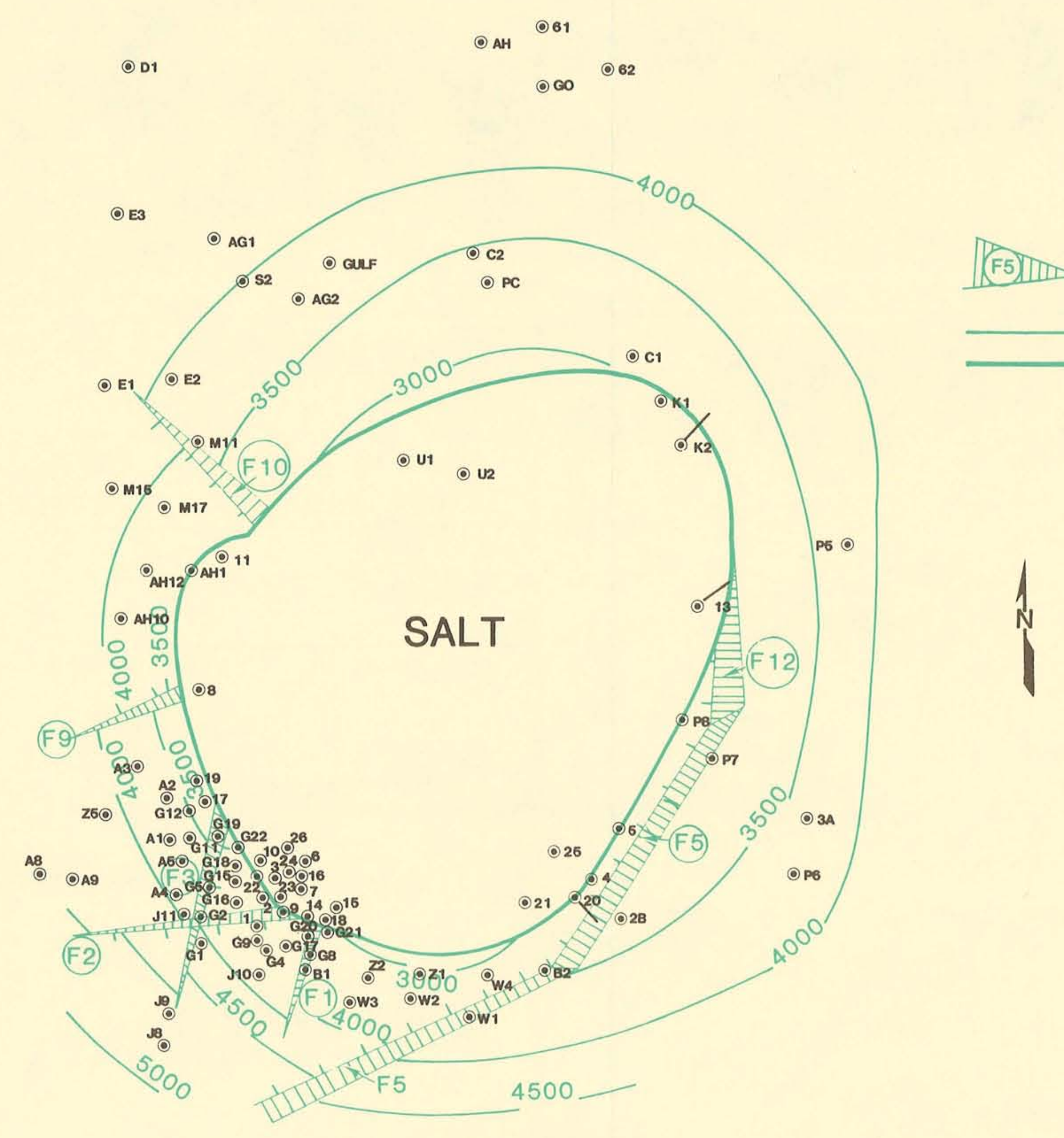


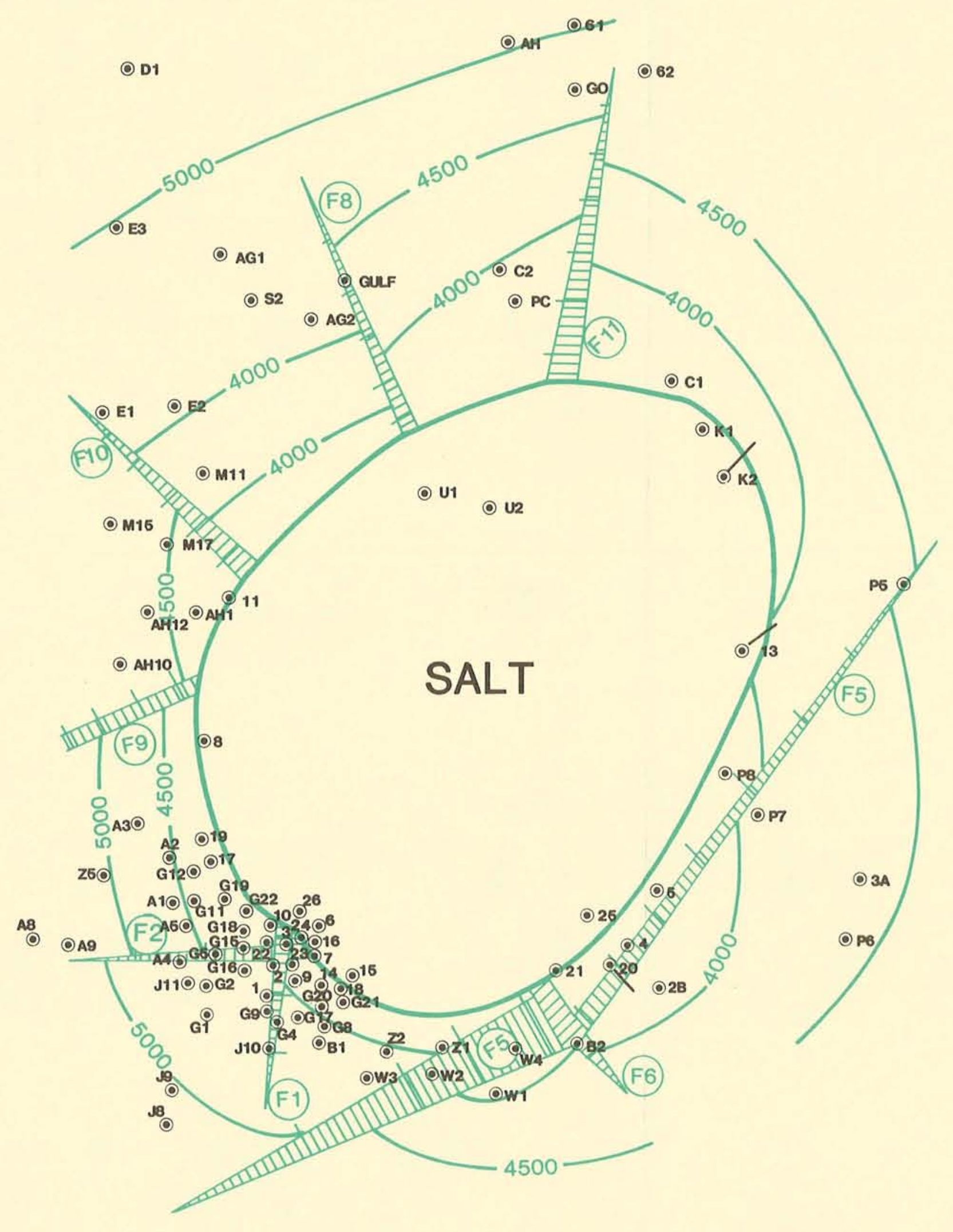

NOTES

1. SEE APPENDIX B FOR

EXPLANATION OF WELL NUMBERS

2. CONTOURED DEPTHS MEASURED IN

FEET BELOW DRILLING FLOOR

$$
\text { LEGEND }
$$

F5 IIID FAULT, EXTENDED HATCHURES ON DOWN SIDE

DEPTH CONTOURS IN FEET

CONTACT WITH SALT

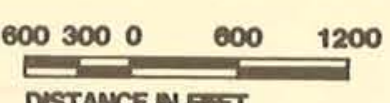

DISTANCE N F्था

BIG HILL SALT DOME STRUCTURE MAP

D SAND

\section{团}

T. R. MAGORIAN

SEP 1981 FIG. 5-33 


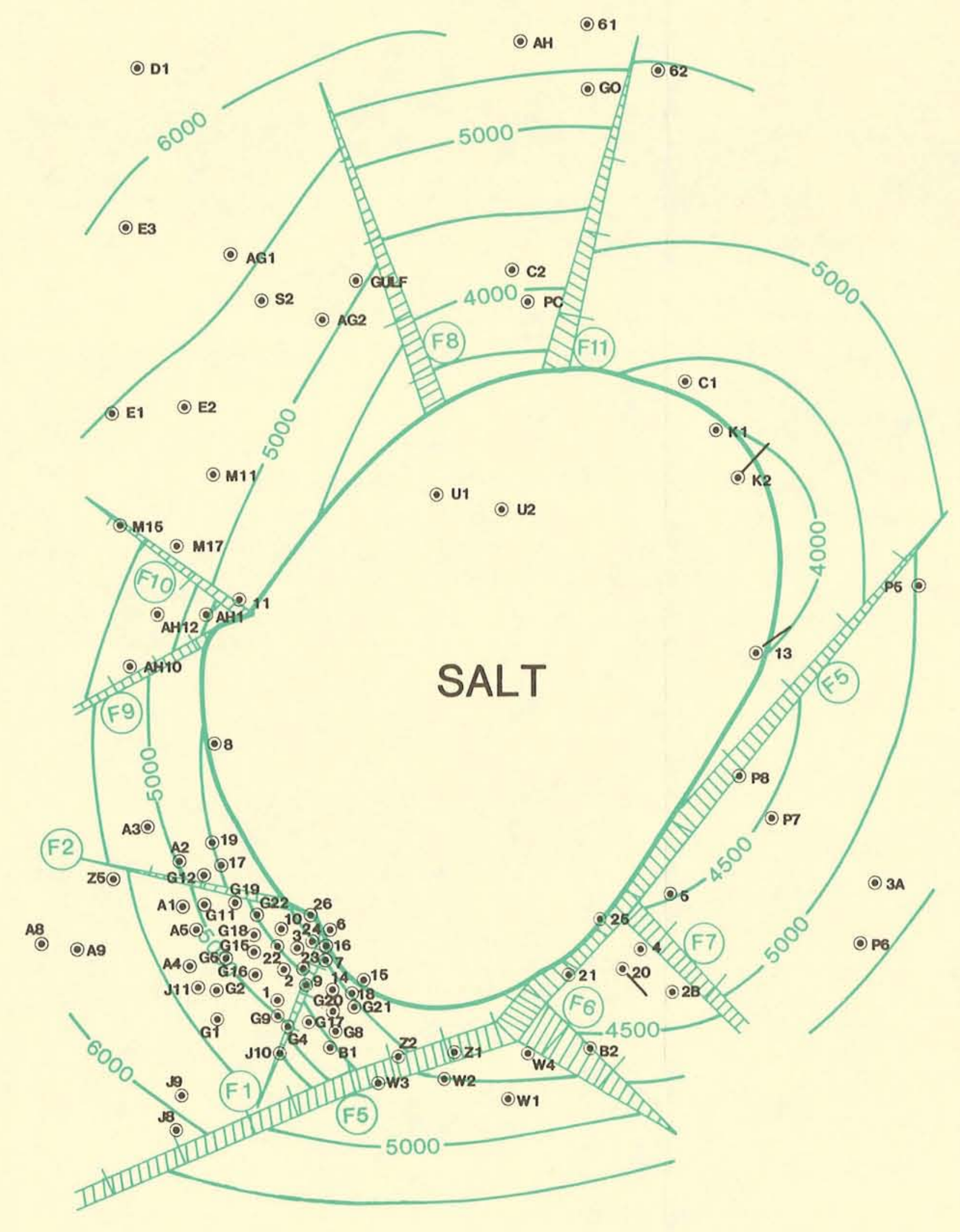

NOTES

1. SEE APPENDIX B FOR

EXPLANATION OF WELL NUMBERS

2. CONTOURED DEPTHS MEASURED $\mathbb{N}$

FEET BELOW DRILLING FLOOR

LEGEND

F5 FAULT, EXTENDED HATCHURES

ON DOWN SIDE

DEPTH CONTOURS IN FEET

CONTACT WITH SALT

$6003000 \quad 600 \quad 1200$

DISTANCE IN FEET

BIG HILL SALT DOME

STRUCTURE MAP

E SAND 


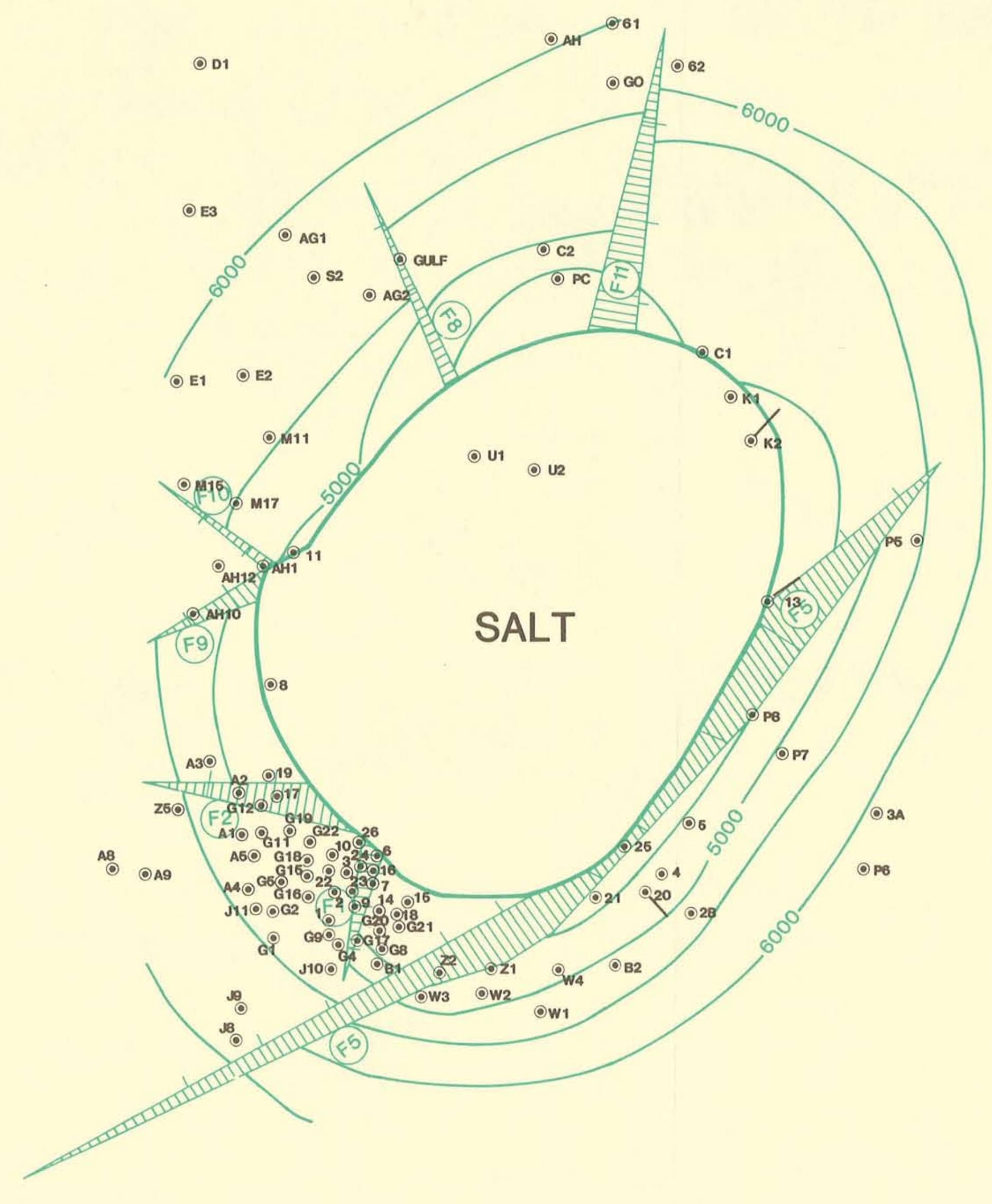

BIG HILL SALT DOME STRUCTURE MAP ANAHUAC SHALE in] National

T. R. MAGORIAN

SEP 1981 FIG. 5-35 


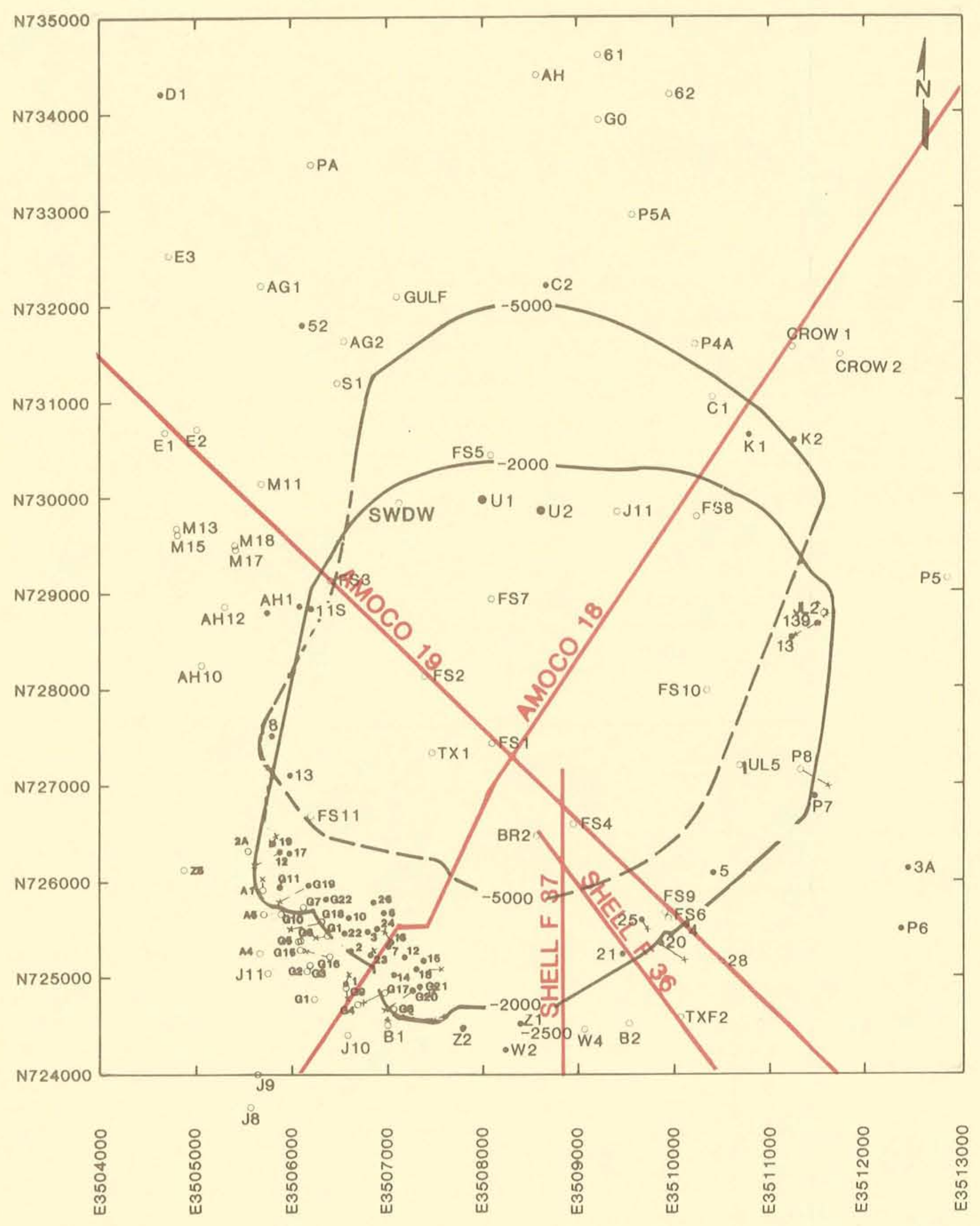

\section{NOTES}

1. SEE APPENDIX B FOR EXPLANATION OF WELL NUMBERS AND WELL LOCATIONS LEGEND

UNION OIL LPG CAVERN

s surface location of well.

- G2 BOTTOM HOLE LOCATION OF WELL.

G2 BotTom hole LOCATION OF SIDETRACK HOLE

OG2 DRILLED AS VERTICAL HOLE. NO BOTTOM HOLE LOCATION AVAILABLE.

G2 LOCATION OF WELL PENETRATING SALT.

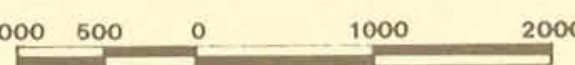


CHAPTER 6 - CAVERN LOCATIONS AND GEOTECHNICAL CONSIDERATIONS

The SPR Phase III expansion program calls for the construction of 140 MMB of storage capacity at Big Hi11. The baseline plan developed by DOE-SPR calls for this storage capacity to be achieved by the construction of 14 10-MMB caverns through solution mining. The objective of the cavern location study was to determine the feasibility of constructing 14 10-MMB caverns on the south part of the dome through the use of (1) the dome definition developed in this site-characterization study, (2) DOE-specified guidelines, and (3) geotechnical criteria necessary to assure cavern structural integrity and stability.

Cavern Layout and Design Criteria

Some of the cavern layout and design criteria and guidelines for this study have been established by the DOE based on system requirements, SPR design consistency, and other studies. These guidelines and criteria include

1. Fourteen 10-MMB caverns, located preferably on the Amoco Production Company property on the south portion of the dome (Figure 2-1)

2. Five oil-withdrawal cycles

3. Initial maximum cavern diameter of $\sim 230 \mathrm{ft}$

4. Cavern height of $2000 \mathrm{ft}$

5. Bottom of caverns not to exceed $6000 \mathrm{ft}$ in depth

The remaining cavern design and spacing criteria are determined by geotechnical considerations of cavern structural adequacy and stability. These criteria are:

1. Pillar-to-diameter (P/D) ratio

2. Salt roof thickness-to-diameter (S/D) ratio

3. Distance from edge of cavern to edge of dome $(E)$ 
The following values of these criteria were used in the cavern location study:

$$
\begin{aligned}
& \text { 1. } P / D=1.78 \\
& \text { 2. } S / D=1 \\
& \text { 3. } E>300 \mathrm{ft}
\end{aligned}
$$

These criteria are considered conservative based on our current knowledge, and some discussion of their basis will help put in perspective the following discussions on cavern size, spacing, and location.

\section{Pillar-to-Diameter (P/D) Ratio}

$P / D$ ratio is the ratio of the thickness of the pillar (or web) between two caverns to the average diameter of the two caverns. It is inversely related to the stress in the web between two caverns for given pressures in the caverns. In determining P/ D for two or more adjacent caverns, we assume the operating conditions that produce the greatest pressure differential between the two caverns. Also, because caverns are rarely symmetrical or straightwalled, right-circular cylinders, a safety factor is included in the calculated $P / D$ to account for such effects. Another consideration in determining $P / D$, especially for a large array of caverns in a dome, such as that planned for SPR, is the effect of salt creep and possible associated surface subsidence.

A P/D ratio of 1.78 was used in the design layout of SPR Phase II (Bryan Mound and West Hackberry) expansion caverns. It was a safe and conservative value at the time, although it was selected on the basis of a limited analysis, limited salt-properties data, and no long-term salt creep data.

More comprehensive analyses based on recently acquired salt properties from other SPR sites and the Waste Isolation Pilot Project (WIPP) site have been carried out since. the SPR Phase II design (Hogan, 1980a; Whiting, 1980; Wawersik, et al, 1980a; Hilton, et al, 1980; Munson and Dawson, 1979; Benzley, 1980; and Wawersik, et al 1980b). Some additional data and experience have also been acquired from analyses and observations of SPR West Hackberry Cavern 6 (Benzley, 1980 and Wawersik, 1980b), and of Bayou Choctaw Caverns 15 and 17 (Hogan, 1980; Hilton, et al, 1980). Analyses of the elastic stress created by pressure differences in two relatively isolated adjacent caverns (zero brine-wellhead pressure in one and zero oil-wellhead pressure in the other), indicates that a P/D of much less than 1.78 is adequate to assure structural stability. However, calculations of secondary (1ong-term)' creep for a large number of caverns in a dome with a $P / D$ of 1.78 or less indicate a significant reduction of cavern volume and a potential for significant surface subsidence over 20- to 30-yr period. Therefore, until enough field data can be acquired to verify or disprove projected creep behavior, the continued use of a P/D of 1.78 is recommended and was used in the Big Hill cavern layout study. 
Salt Roof Thickness-to-Diameter (S/D) Ratio

The ratio of the thickness of the salt roof over the cavern to the diameter of the cavern (S/D) is an expression of the structural adequacy of the salt roof. S/D must be great enough so that the salt roof is selfsupporting; i.e., no tensile stresses are developed in the salt roof for worst-case pressures. For salt properties typical of nearly pure halite in the Gulf Coast salt domes, analyses indicate that an S/D $\geq 1$ is adequate (Ney, 1981). For a cavern diameter of $270 \mathrm{ft}$ (the diameter of the SPR caverns at the end of five withdrawal cycles), the minimum roof thickness is then $270 \mathrm{ft}$. This thickness of salt roof also provides adequate salt above the cavern for good cementation of the production casing in the salt. However, in practice the SPR Phase II caverns have been designed with a salt roof tnickness of $450 \mathrm{ft}$. That value will therefore be used in the baseline cavern layout for Big Hill. In the case of Big Hill, little data are available to accurately define the elevation contour of the top of the salt over the south half of the dome. The lowest elevation of the top of the salt at the planned SPR cavern locations on the south half of the dome is estimated as $180 \mathrm{u} \mathrm{ft}$ below tine surface. For the baseline cavern layout, the top of the caverns is $2250 \mathrm{ft}$ below msl, which should provide at least $450 \mathrm{ft}$ of salt roof. This results in an S/D of 1.7. If salt is encountered at a higher elevation during drilling of the first few cavern wells, the tops of the caverns should be set correspondingly higher to provide a larger edge-ofdome margin as discussed below.

There are several reasons it is desirable to construct the caverns as near the top of the salt as feasible, particularly at Big Hill. For a given cavern height, frictional losses and required pumping pressures are minimum for a minimum cavern depth both during leaching and $0 i 1$ fill and withdrawal. So there is a savings of power costs for a shallower cavern. Perhaps a more serious consideration is the increase in the rate of secondary salt creep with depth. Analyses based on data derived from laboratory tests of salt from the Bryan Mound and West Hackberry domes (Wawersik, et al, 1980a and 1980b) indicate an exponential relationship between secondary creep rate and stress (depth) as shown in Figure 6-1. Creep rate increases exponentially with depth because it is an exponential function of both stress and temperature, both of which increase with depth. Although Figure 6-1 is an approximation intended only to illustrate the general relationship between depth and creep rate, the difference in secondary creep rate between depths of $4500 \mathrm{ft}$ and j000 ft may be significant. Creep reduces cavern volume, which increases wellhead pressures and requires continuing bleedoff of brine or stored $0 i 1$. Further, at the cavern depths being considered, long-term creep may result in significant surface subsiderice. It is thus desirable to construct the caverns at the shallowest feasible depth to minimize creep rate.

It is also necessary to construct the caverns at the shallowest feasible depth because of the steep slope of the salt overhang on the south side of the Big Hill dome. As Figure 6-2 shows, for a given cavern diameter and neight, cavern depth must be minimized to maintain the desired distance from. the edge of the cavern to the edge of the dome for caverns on the southern periphery of the dome. 
Edge of Cavern to Edge of Dome (E)

Our analyses (Ney, 1981) indicate that $50 \mathrm{ft}$ of good quality (structurally competent) salt between the edge of cavern and the edge of the dome would be structurally adequate for zero surface-oil pressure (worst-case operating or accident conditions). However, the actual quality of salt near the dome edge at $\mathrm{Big} \mathrm{Hill}$ is unknown. For Big Hill, where relatively little data are available to define the edge of the dome, a tolerance $\pm 100 \mathrm{ft}$ is associated with the geological interpretation of the dome edge at a depth of $5000 \mathrm{ft}$ (maximum depth of sump). To account for these and other tolerances and uncertainties, a minimum edge distance of $E=300 \mathrm{ft}$ is used in the cavern location layout, as shown in Figure 6-2.

\section{Edge of Cavern to Property Line}

According to the Texas Railroad Commission, no regulations specify or control the proximity of a storage cavern to the owner's property 1 ine in Texas. The Commission has informed us that the Texas state legislature is assigning authority to regulate storage cavern construction and operations to the Railroad Commission. Although no regulations in Texas control the spacing of storage caverns from property lines, in practice the cavern operators at Barber's Hill dome in Texas, for example, have constructed their caverns $\sim 150 \mathrm{ft}$ from their property lines.

Since $P / D$ is the stability parameter controlling the distance between two adjacent caverns, it should be applied in determining distance from the caverns to the property line where there is enough salt for a cavern on adjacent property. For adjacent caverns $270 \mathrm{ft}$ in diameter (the diameter of SPR caverns after five withdrawal cycles) and $P / D=1.78$, the pillar width is $480 \mathrm{ft}$.

A cavern spacing of $190 \mathrm{ft}$ from the north property line was chosen for the baseline cavern layout. As shown in Figure 6-3, if a cavern-to-property 1 ine distance of $190 \mathrm{ft}$ is maintained by each property owner, the required pillar width of $480 \mathrm{ft}$ will be achieved for caverns $270 \mathrm{ft}$ in diameter. Even if Texas adopts a 100-ft spacing (as Louisiana has) and the adjoining property owner chooses to use this minimum spacing, he could still construct a cavern $190 \mathrm{ft}$ in diameter without violating the $P / D$ criterion of 1.78 . (The diameter used in calculating $P / D$ when the caverns are of different diameters is the average diameter of the two.) Larger cavern-to-property 1 ine spacings for the SPR caverns that would assure maintenance of required pillar width under all possible conditions were considered. But increasing the spacing of the caverns from the north property line shifts the whole cavern complex to the south and decreases the distance from the edge of the salt dome to the caverns on the bottom row. Because of the limited data upon which the salt contours are based, the distance from cavern to edge of dome is of much greater concern than increased spacing from the property line beyond the $190 \mathrm{ft}$. 
Basel ine Cavern Layout

Using the guidelines and geotechnical criteria outlined in this chapter, we have determined that it is feasible to construct 14 10-MMB storage caverns on the south portion of the Big Hill dome as shown in Figures 6-2 and 6-4. Figure 6-2 is not an accurate cross section of the dome but simply a schematic showing the required relationship of the planned SPR caverns to the top of the salt and the edge of the dome. The coordinates given in Figure 6-4 are for the center of the caverns. Figures 5-5, 5-6, and 5-7 are west-east cross sections through the three rows of the planned SPR caverns showing the relationship of the caverns to the salt-dome boundaries. Note that in all three of these cross sections (cavern rows) there appears to be space for an additional cavern on the west (left) side. The caverns were located nearer the east side of the dome because the risk of an unexpectedly deep overhang reentrant on the west flank of the dome is higher than on the east side, as indicated by the deeper $D$ and $E$ sands on the west flank.

No separate exploratory well program or geophysical exploration program is required to proceed with the design of the site and construction of the caverns according to this baseline layout. However, because the Big Hill dome is relatively unexplored and the geological interpretation of the salt contours is based on sparse data, exploratory extension of some cavern wells is recommended to verify the geological interpretations. Also, a comprehensive geophysical, cavern well-logging and coring program is required to obtain salt and cap rock material properties and to complete characterization of the dome. The drilling extension and logging and coring programs are presented in detail later in this chapter.

\section{Potential Expansion Cavern Layout}

The feasibility of constructing additional caverns on the south portion of the dome was investigated. To provide the option of adding Phase IV expansion caverns after the construction of the Phase III caverns, the baseline cavern layout was maintained and the feasibility of adding caverns to the baseline was addressed. The same geotechnical criteria used in the baseline layout were used in the feasibility study of additional caverns for possible Phase IV expansion.

Figures 6-5 through 6-8 show the results of the feasibility study and the potential for expansion of the SPR site at Big Hill to a total of 19 caverns. Note that Figures 6-6, 6-7, and 6-8 are repeats of the sections shown in Figures $5-5,5-6$, and $5-7$ with an additional cavern added to the west end of each row of caverns. The five additional caverns are numbered in order of geotechnically preferred cavern location. Cavern Location $\times 3$ would require the purchase of the 6-acre rectangular tract of land on the south side and west end of the Sabine Pass Terminal property (Figure 6-5). Amoco Wel1 8, west of Cavern $X 1$, bottomed out in salt at a depth of $5200 \mathrm{ft}$, thus providing good well control for the location of this expansion cavern on the west end of the middle row of caverns (Figure 6-7). There appears to be about $400 \mathrm{ft}$ of salt between Caverns $X 2$ and $X 3$ and the edge of the dome at a depth 
of $5000 \mathrm{ft}$. Amoco Wel1s 8 and 11 provide control for X2 in the top row of caverns (Figure 6-6). Caverns could be constructed at Locations X1, X2, and $X 3$ without further geological or geophysical exploration, assuming that the exploratory extension drilling program outlined in the next section is implemented during drilling. Additional data defining the edge of the dome would be required before the construction of caverns at Locations $X 4$ and $X 5$.

\section{Exploratory Extension of Cavern Wells}

The Big Hill dome is relatively unexplored. Few wells have been drilled on the southern periphery of the dome that penetrate and/or exit the salt at the critical elevations required to accurately define the salt contours at the elevations of concern for cavern layouts. Salt contours at -4000 to -5000-ft elevations in particular were derived from geological interpretations of 7 imited data. One method of verifying these interpretations is to drit1 exploratory holes 5000 to $6000 \mathrm{ft}$ deep around the south side of the dome in a few critical places. The cost of such an exploratory program would be $\sim \$ 4$ to $\$ 5$ million. An alternative to drilling exploratory holes is to drill 300-ft-deep extensions of the cavern wells that are adjacent to the dome edge as shown in Figure 6-9. This drilling extension program will help assure that the desired distance from the cavern to the edge of the dome is achieved. The additional cost of drilling an extension $300 \mathrm{ft}$ deep would not exceed a few thousand dollars per well. This program is recommended for one of the wells in Caverns 101, 111, and 114. To confirm that the planned cavern layout is feasible, the wells for these three caverns should be drilled first.

The extension should be drilled to a depth $300 \mathrm{ft}$ below the bottom of the cavern sump to ensure adequate salt thickness. Thirty feet of additional core should be taken from these extensions of the holes for lithological and mineralogical analyses. A complete set of geophysical well logs should also be run and analyzed. Precautions should be taken in case the hole is drilled through the salt into the underlying sediments. Strata near the salt overhang may be overpressured, and heavy drilling fluid may be required. The exploratory extension of the holes should be completely plugged with cement after analysis of the logs and visual inspection of the core. If the extended hole breaks out of the salt, the well should be pressure-tested after plugging the extension to make certain that there is no leak from the sediments to the cavern or vice versa.

\section{Wel1-Logging and Coring Program}

A comprehensive wel1-logging and coring program for Big $\mathrm{Hill}$ is essential to acquire data for completing geological characterization of the dome, to provide supporting data for the cavern leaching program, and to support a materials test program. In addition, analysis of water samples from the cap rock is required to evaluate potential long-term corrosion of the casing.

The following logs should be run in each cavern we11: 


$\frac{\text { Type of Log }}{\text { 4-arm caliper }}$
cement bond log
gyroscopic survey
casing collar
gamma ray
neutron log
density log
sonic log
seismic velocity

$\frac{\text { Determination }}{\text { borehole geometry }}$

casing to formation bond borehole deviation depths of casing collars radioactivity associated with shale or potassiumbearing evaporites

lithology porosity, clay (hydrogen content)

bulk log density lithology, porosity

$$
\begin{aligned}
& \text { lithology, porosity } \\
& \text { seismic velocity of cap } \\
& \text { rock and salt }
\end{aligned}
$$

Depth

before each casing is set and to total depth in final configuration
a)1 casing*
0 to total depth
0 to total depth

all salt

0 to total depth

0 to total depth

0 to total depth

0 to total depth in at least 4 wells

Additional logs that should be run under special circumstances include resistivity, dipmeter, and temperature.

Data should be obtained in both analog and digital form. The analog data should be analyzed immediately by the onsite geologist to determine if additional logs are warranted. Anomalous zones should be reported and sidewall samples of those zones taken. At least 24 sidewall samples should be taken in each hole and analyzed immediately.

Digital log data are required to take advantage of specialized computer programs to determine material properties, to generate combined data plots, and to determine formation 1ithology. A combination of sonic and density logs allows determination of mechanical properties like shear modulus and bulk compressibility. A combination of gamma-ray, sonic, neutron, density, and caliper logs allows for interpretation of the percentage of halite, sylvite, and insolubles.

If it should become necessary at some future time to do geological/ geophysical exploration at Big Hill in connection with SPR development, good records of the seismic velocity of the cap rock and salt would prove invaluable. Such data can only be acquired before casing is installed.

\footnotetext{
* The cement bond $\log$ is not definitive in large (diameter >14 in.) casing. Therefore it is essential that good drilling, casing, and cementing records be available.
} 
A program to collect and analyze drill cuttings should be maintained, with cuttings labeled and preserved. Drilling fluid should al so be monitored.

Ideally, core taken from each hole should include a 30-ft core from the cap-rock/salt interface, a 60-ft core from the roof of the cavern, a 60-ft core from the middle elevation of the cavern, and a 60-ft core from the bottom of the 300-ft extension of the driliholes. The minimum coring program should consist of a 30-ft core from the $-2200-f t$ elevation, the $-3200-f t$ elevation, and the bottom of the 300-ft extension of the drillholes in one well each from Caverns 101, 111, and 114. If the minimum coring program is implemented, it is imperative that side wall sampling be flexible. Both coring and drilling in salt should be done with salt-saturated drilling fluid. The onsite geologist should inspect the core immediately and record a core analysis. The core should then be properly packaged for shipment by sealing it in a waterproof material, careful assembly into an appropriate shock-absorbing material, and packaging into a rigid container before shipment to the testing laboratory for detailed analysis. Determination of mechanical, chemical, and mineralogical properties supports structural modeling of the caverns, as well as the leaching program. The next section outlines the proposed material testing program.

Finally, as the drilling program progresses and new cap rock and topof-salt data are acquired, the site geologist should modify the working contour maps on a timely basis to better prepare for upcoming drilling. Sandia will continue to update contour maps as information is received.

From the experience of the Union $0 i 1$ Company with their storage cavern, it is known that some of the Big Hill cap-rock water is corrosive. Water samples from the cap rock are required to evaluate the potential corrosion of SPR well casing. Water samples should be taken from the cap-rock interval, one per hole, from several holes. Water is present in the vugs of the cap rock, which are also likely to be zones of lost circulation. If lost circulation occurs, the hole should be bailed to allow flushing of drilling fluid; a water sample should then be taken by means of a drill stem test and sent immediately for analysis.

\section{Material Properties Program}

A comprehensive material properties program similar to those done by Sandia for Bryan Mound and West Hackberry (Whiting, 1980 and Hilton, et al, 1980) will be needed to support cavern leaching and the analytical program for evaluating both near- and long-term structural stability of the caverns. When available, results of the material properties program should be incorporated into this site-characterization report.

The material properties program will provide a complete definition of the salt in the SPR cavern wells at selected intervals. This program will use core, sidewall samples, and drill cuttings in lab tests along with well logs to obtain the following chemical and mineralogical properties of the salt and brine: 


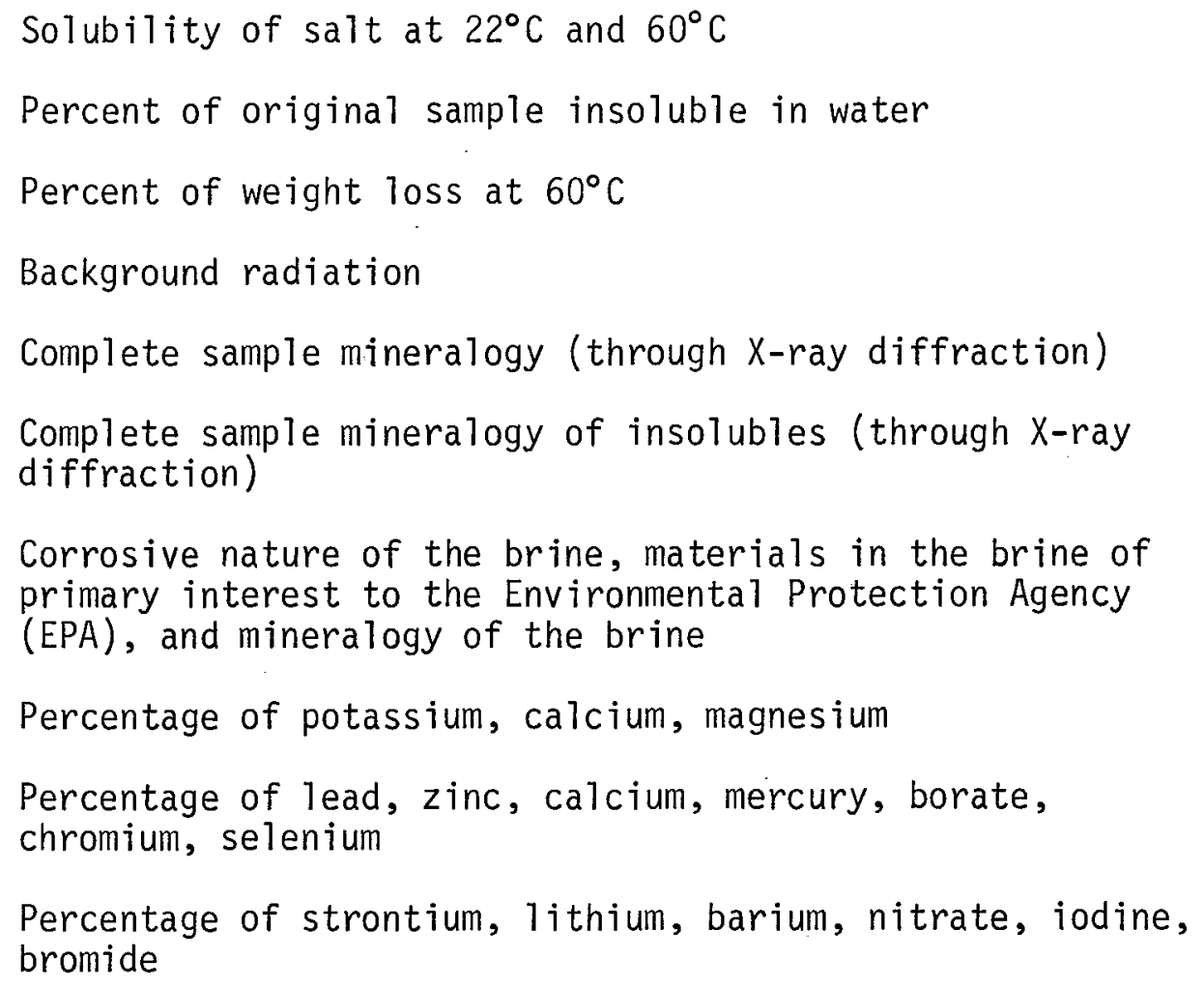

The following physical and mechanical properties of the salt should be obtained over the range of variables listed below:

\section{Physical and Mechancial Properties}

Density

Megascopic physical descriptions

Stress-strain behavior, onset of nonelastic behavior, strain hardening, strength

Young's modulus

Poisson's ratio

Thermal expansion

\section{Elongation}

$P$ and $S$ wave velocities 
Temperature $\left({ }^{\circ} \mathrm{C}\right): 22$ and 60

Confinement (psi): $0,500,3000,5000$ (as time permits)

Load rate $=0.5 \mathrm{psi} / \mathrm{s}, 15 \mathrm{psi} / \mathrm{s}$, constant strain rate

Moisture content and accessory minerals

Load path: triaxial compression $\left(\sigma_{2}=\sigma_{3}\right)$

$$
\text { triaxial extension }\left(\sigma_{2}=\sigma_{1}\right) \text { tension }
$$

Cyclic loading

Primary, secondary (steady-state) and tertiary (accelerated) creep (strain vs time) should be obtained over the following range of variables:

Temperature $\left({ }^{\circ} \mathrm{C}\right): 22$ and 60

Confinement (psi): 500, 3000,5000 (as time permits)

Moisture content

Stress difference (at three values between 1000 and 4500) 


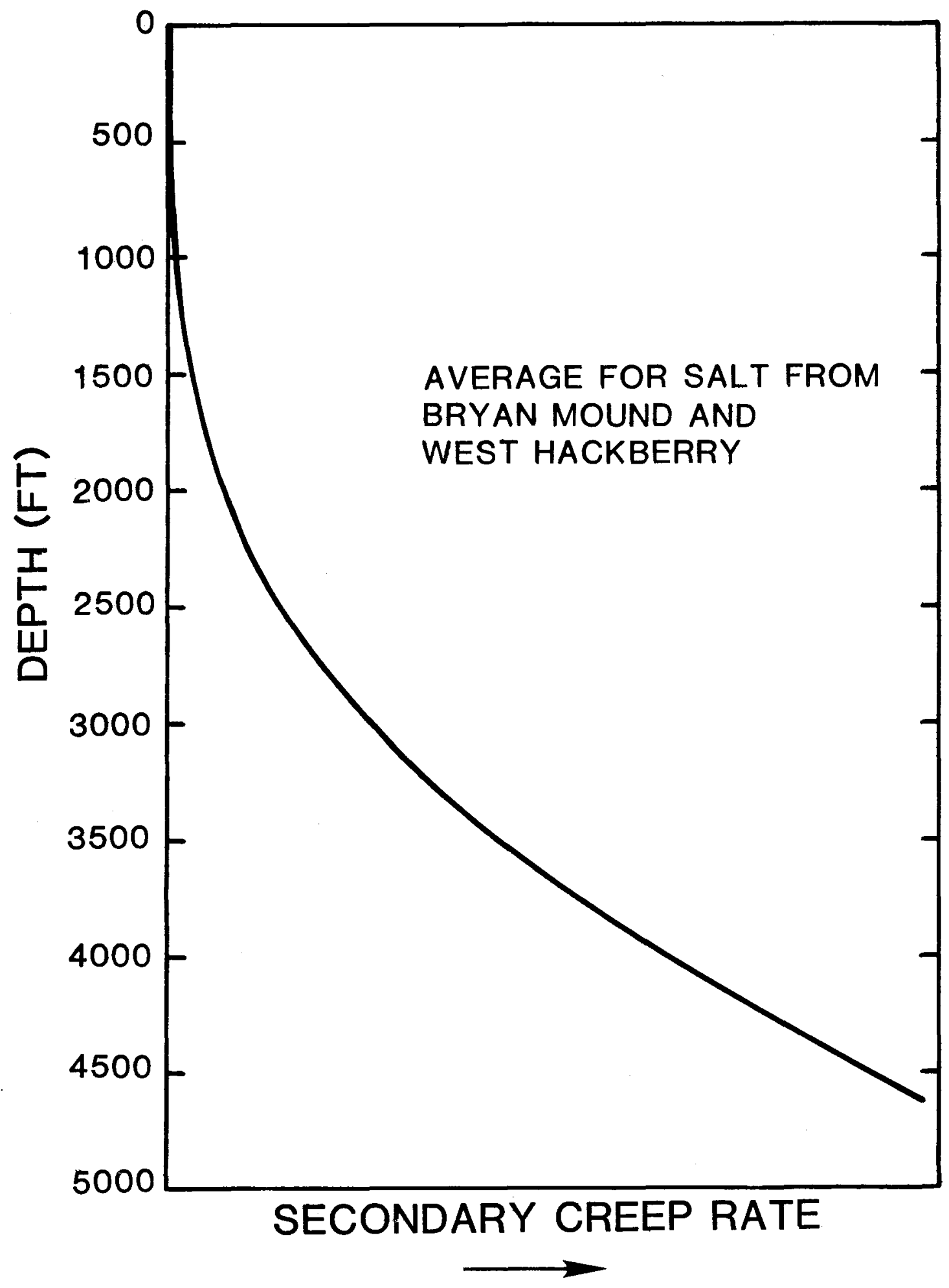

DEPTH VS SECONDARY CREEP RATE 
SURFACE - MSL

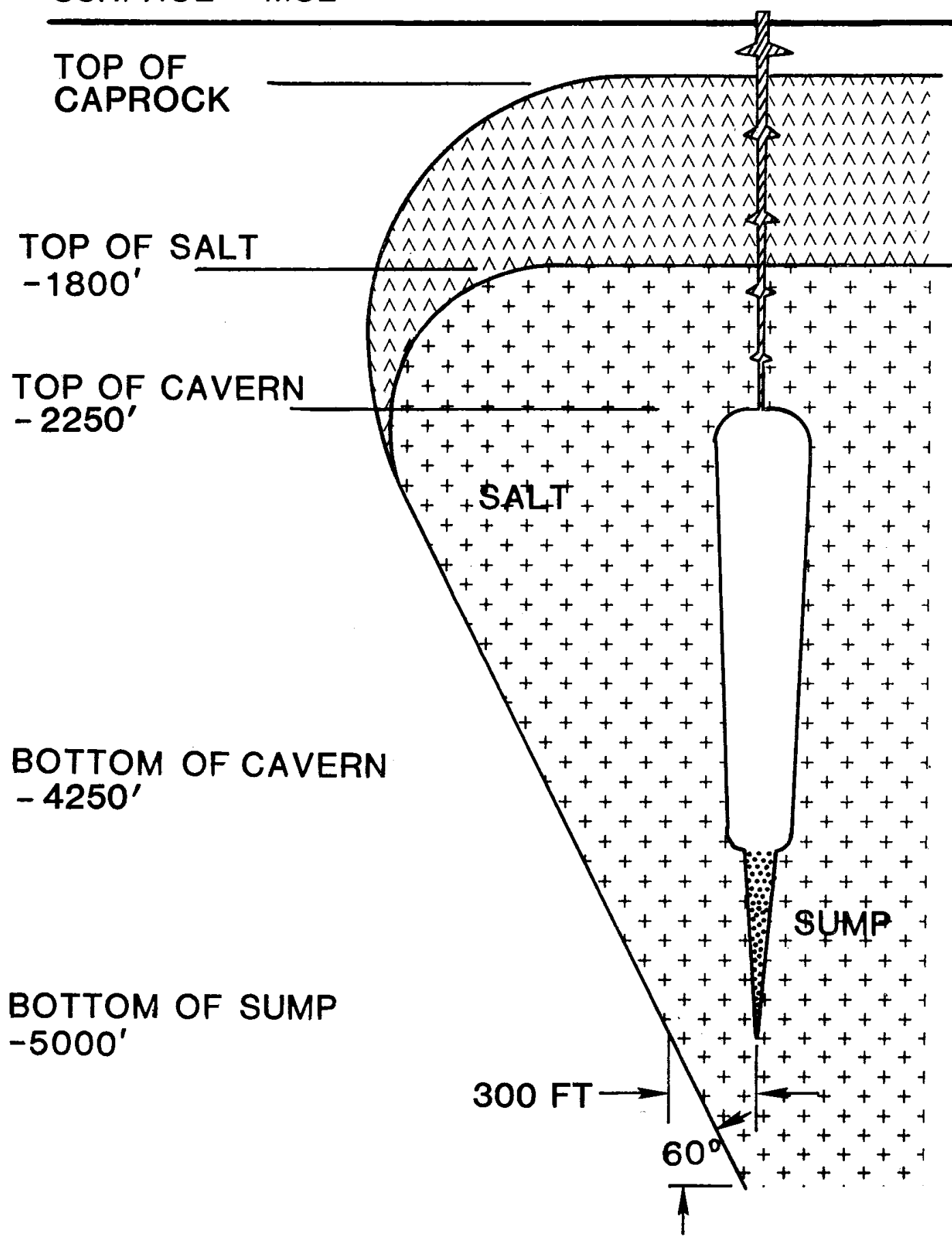

BIG HILL SALT DOME CAVERN DESIGN AND LOCATION 


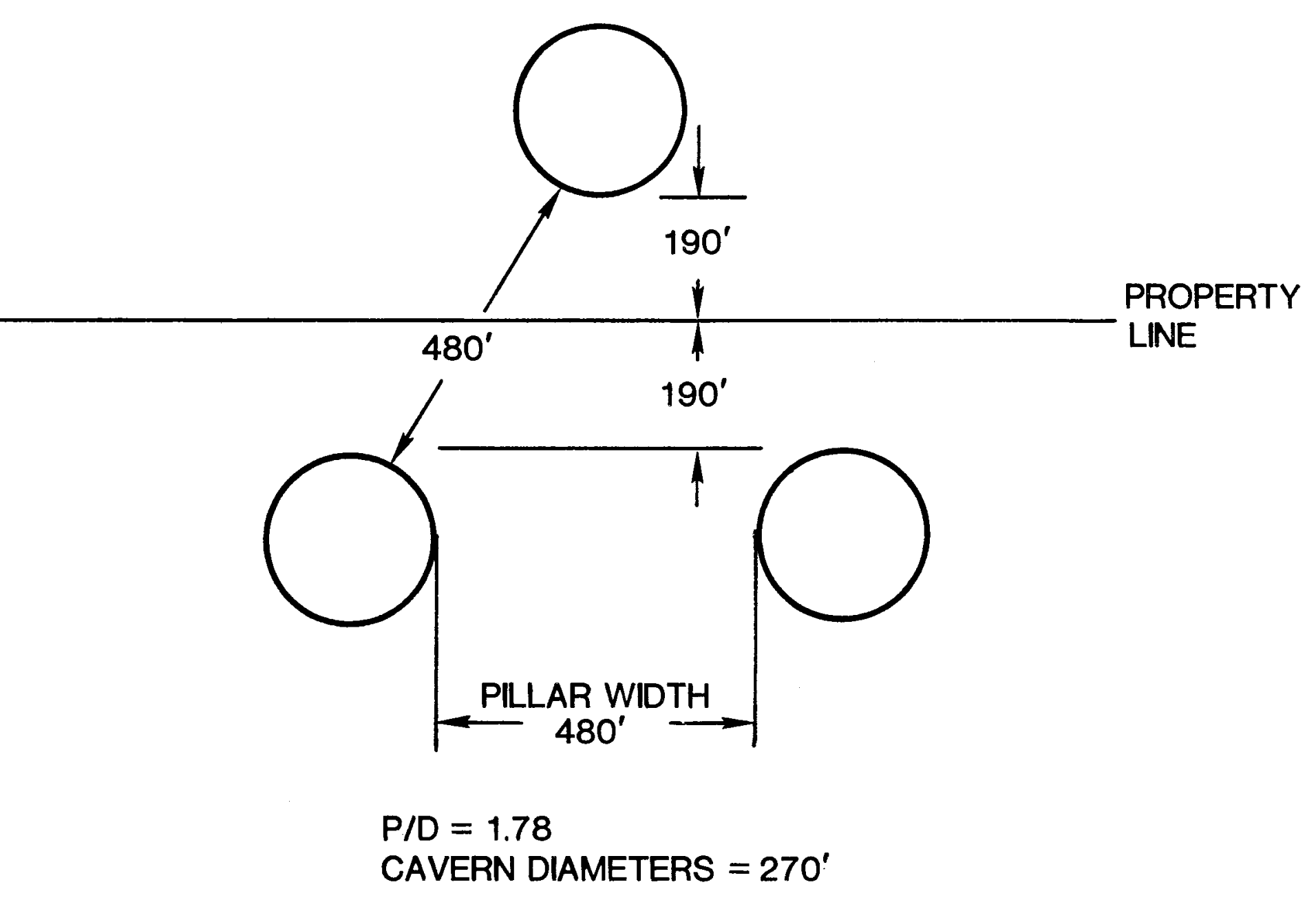

BIG HILL SALT DOME CAVERN-TO-PROPERTY LINE SPACING 


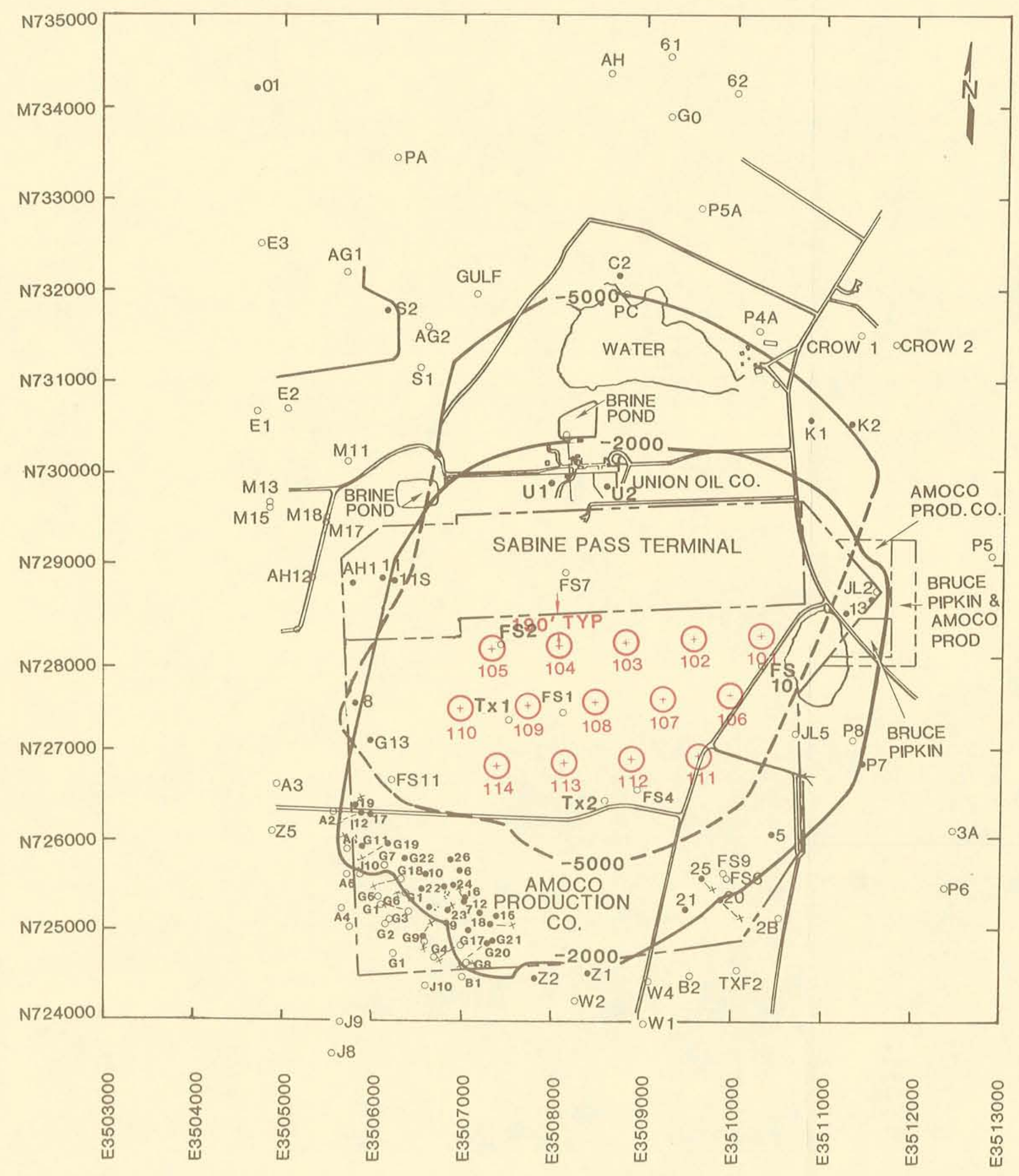

CAVERN LOCATION TABLE CAV \# NORTH EAST $101 \quad 728250.45 \quad 3510231.68$ $\begin{array}{lll}101 & 728250.45 & 3510231.68\end{array}$ $\begin{array}{llll}102 & 728214.66 & 3509482.52\end{array}$ $\begin{array}{cccc}103 & 728178.87 & 3508733.39 \\ 104 & 728143.09 & 3507984.23\end{array}$ $\begin{array}{rrrr}104 & 728143.09 & 3507984.23 \\ 105 & 728107.30 & 3507235.09\end{array}$ $\begin{array}{llll}105 & 728107.30 & 3507235.09 \\ 106 & 727583.79 & 3509888.10\end{array}$ $107 \quad 727548.00 \quad 3500138.95$ $108 \quad 727512.21 \quad 3508389.79$ $\begin{array}{rrr}108 & 727512.21 & 3508389.79 \\ 109 & 727476.43 & 3507640.64\end{array}$ $\begin{array}{llll}109 & 727476.43 & 3507640.64 \\ 110 & 727440.65 & 3506891.51\end{array}$ $\begin{array}{lll}110 & 727440.65 & 3506891.51 \\ 111 & 726917.14 & 3509544.51\end{array}$ $\begin{array}{lllll}112 & 726881.34 & 3508795.35\end{array}$ $\begin{array}{lllll}113 & 726845.56 & 3508046.23\end{array}$ $\begin{array}{lll}114 & 726809.77 & 3507297.08\end{array}$

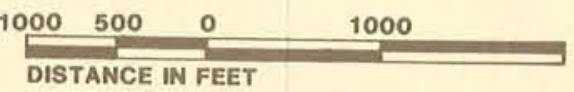

BIG HILL SALT DOME CAVERN LAYOUT BASELINE (1) Sandia SEP 1981 


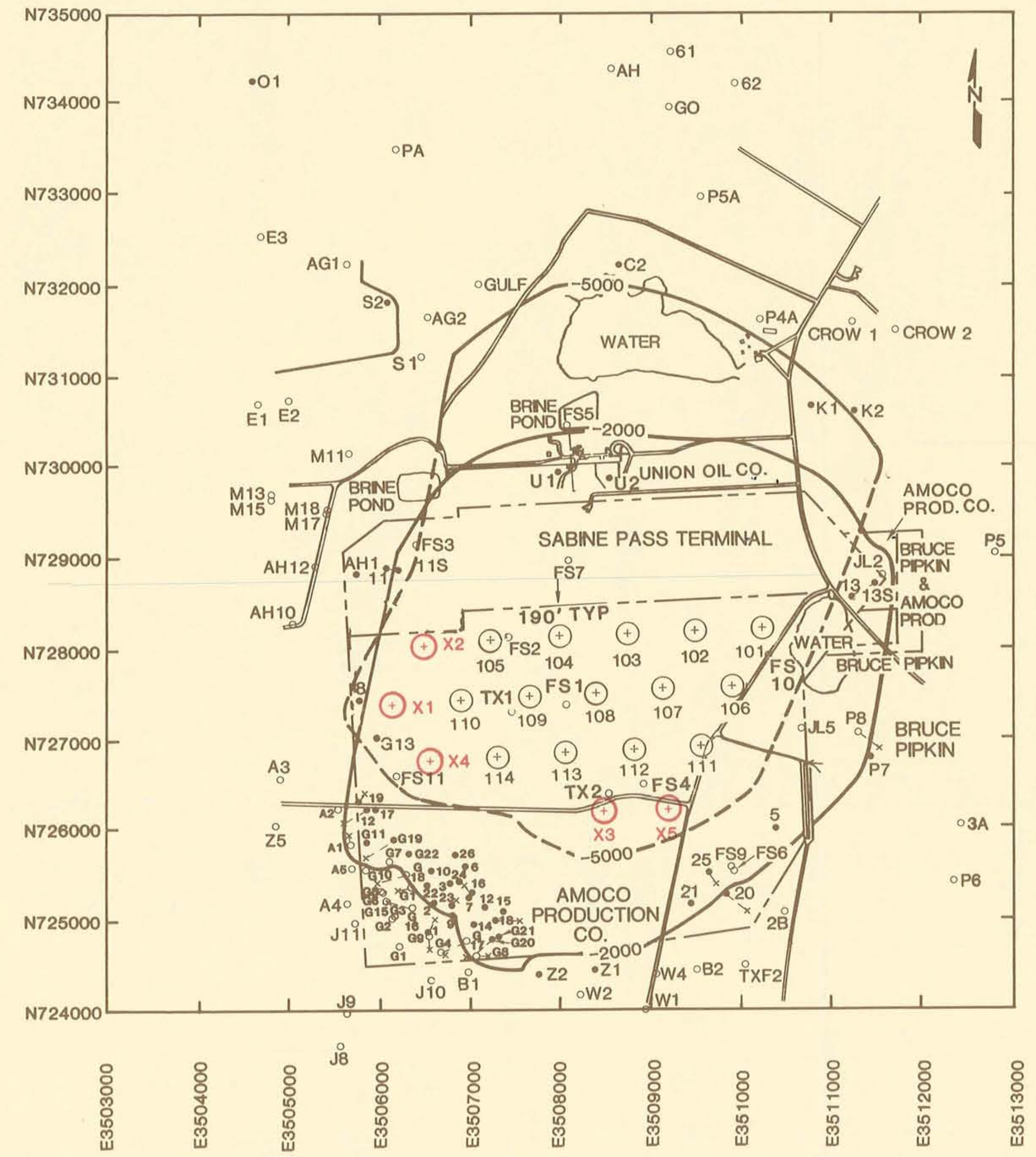

CAVERN LOCATION TABLE

CAV \# NORTH EAST

$\begin{array}{lll}101 & 728250.45 & 3510231.68\end{array}$

$\begin{array}{llll}102 & 728214.66 & 3509482.52\end{array}$

$\begin{array}{llll}103 & 728178.87 & 3508733.39\end{array}$

$104 \quad 728143.09 \quad 3507984.23$

$\begin{array}{lll}105 & 728107.30 \quad 3507235.09\end{array}$

$106 \quad 727583.79 \quad 3509888.10$

$\begin{array}{llll}107 & 727548.00 & 3509138.95\end{array}$

$\begin{array}{lllll}108 & 727512.21 & 3508389.79\end{array}$

$\begin{array}{lllll}09 & 727476.43 & 3507640.64\end{array}$

$110 \quad 727440.65 \quad 3506891.51$

$\begin{array}{lllll}112 & 726881.34 & 3508795.35\end{array}$

$113 \quad 726845.56 \quad 3508046.23$

$\begin{array}{llll}114 & 726809.77 & 3507297.08\end{array}$

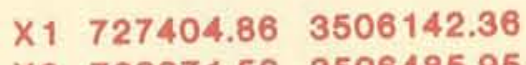

$X 2728071.52 \quad 3506485.95$
$X 3$

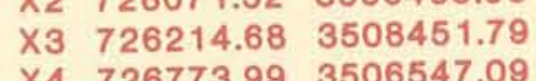

$\times 5 \quad 726250.46 \quad 3509201.77$

$1000600 \quad 0$

Detame
POTENTIAL EXPANSION

CAVERN LAYOUT

BIG HILL SALT DOME

iv Nantional

SEP 1981 


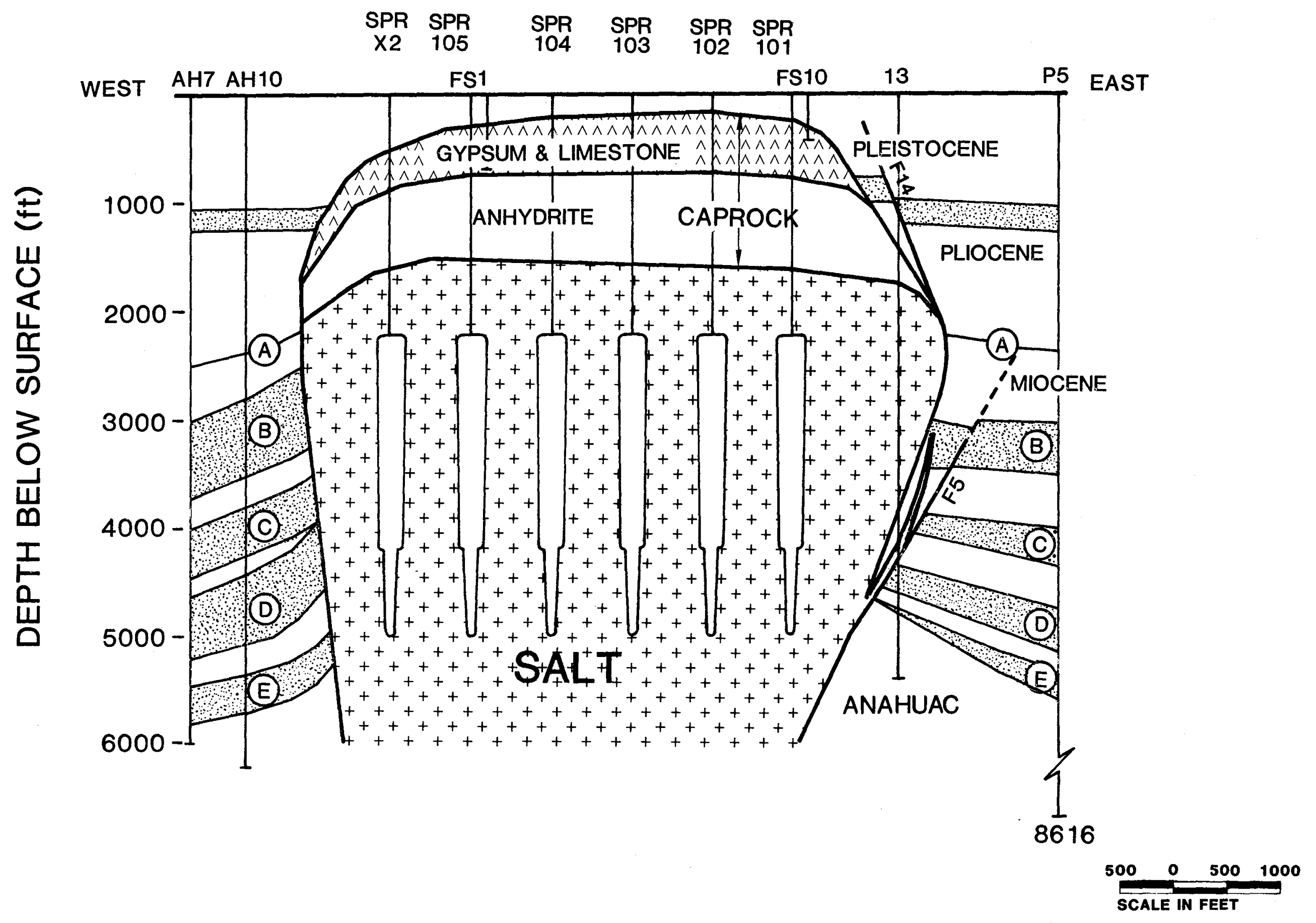

BIG HILL SALT DOME WEST-EAST CROSS SECTION NO. 1 


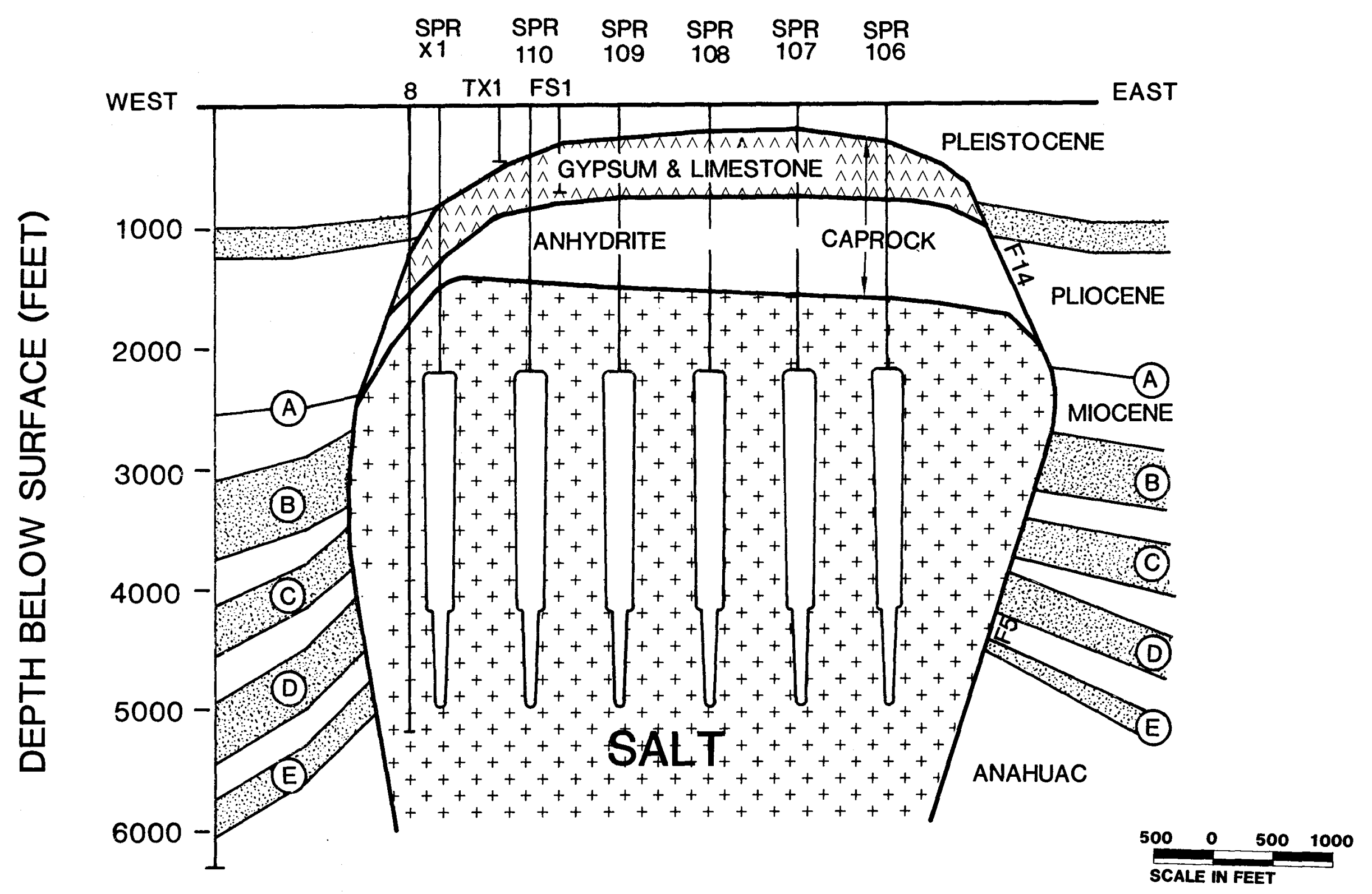

BIG HILL SALT DOME WEST-EAST CROSS SECTION NO. 2 


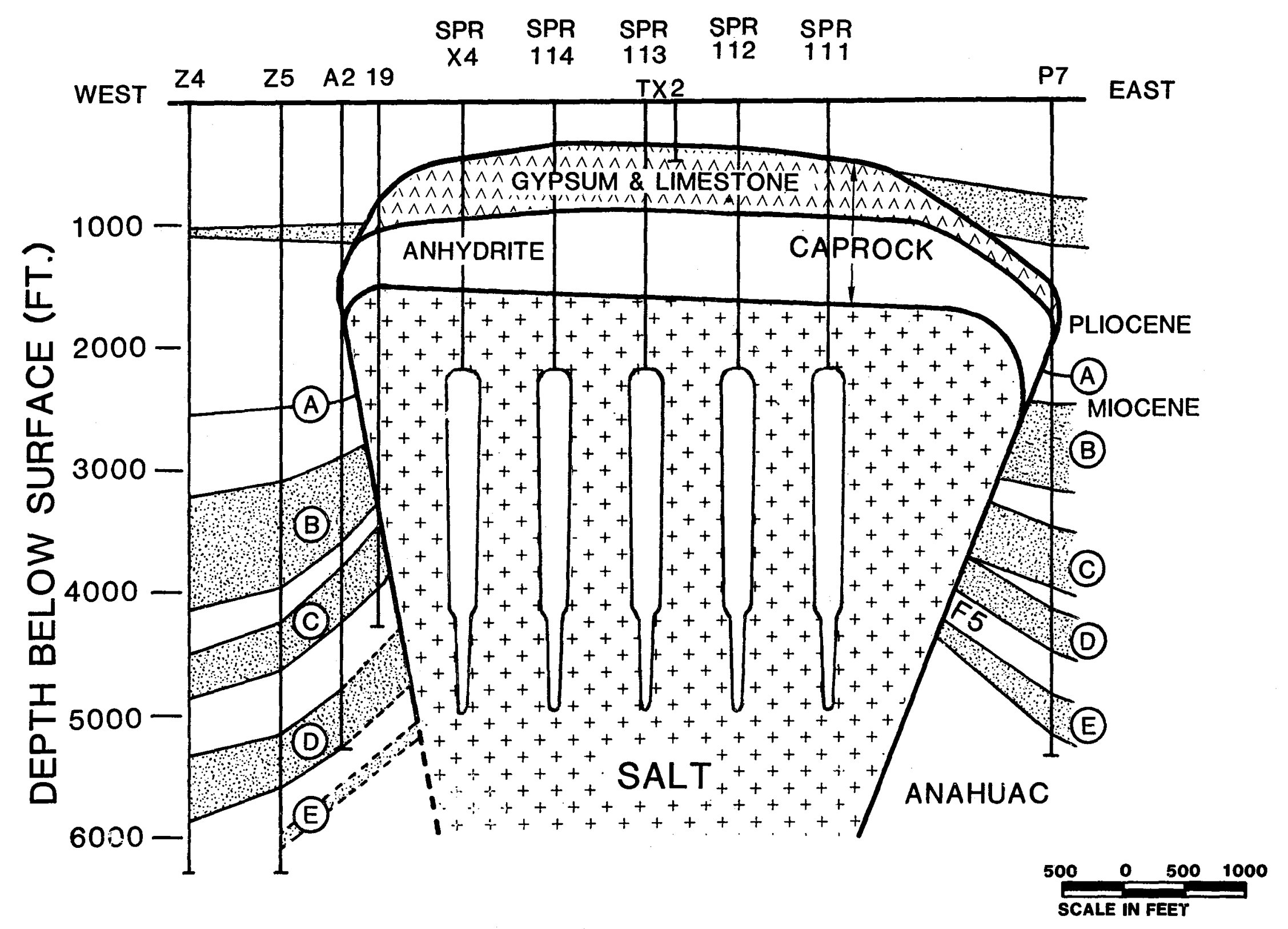

BIG HILL SALT DOME WEST-EAST CROSS SECTION NO. 3

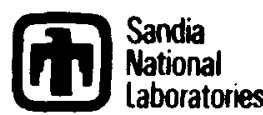


SURFACE - MSL

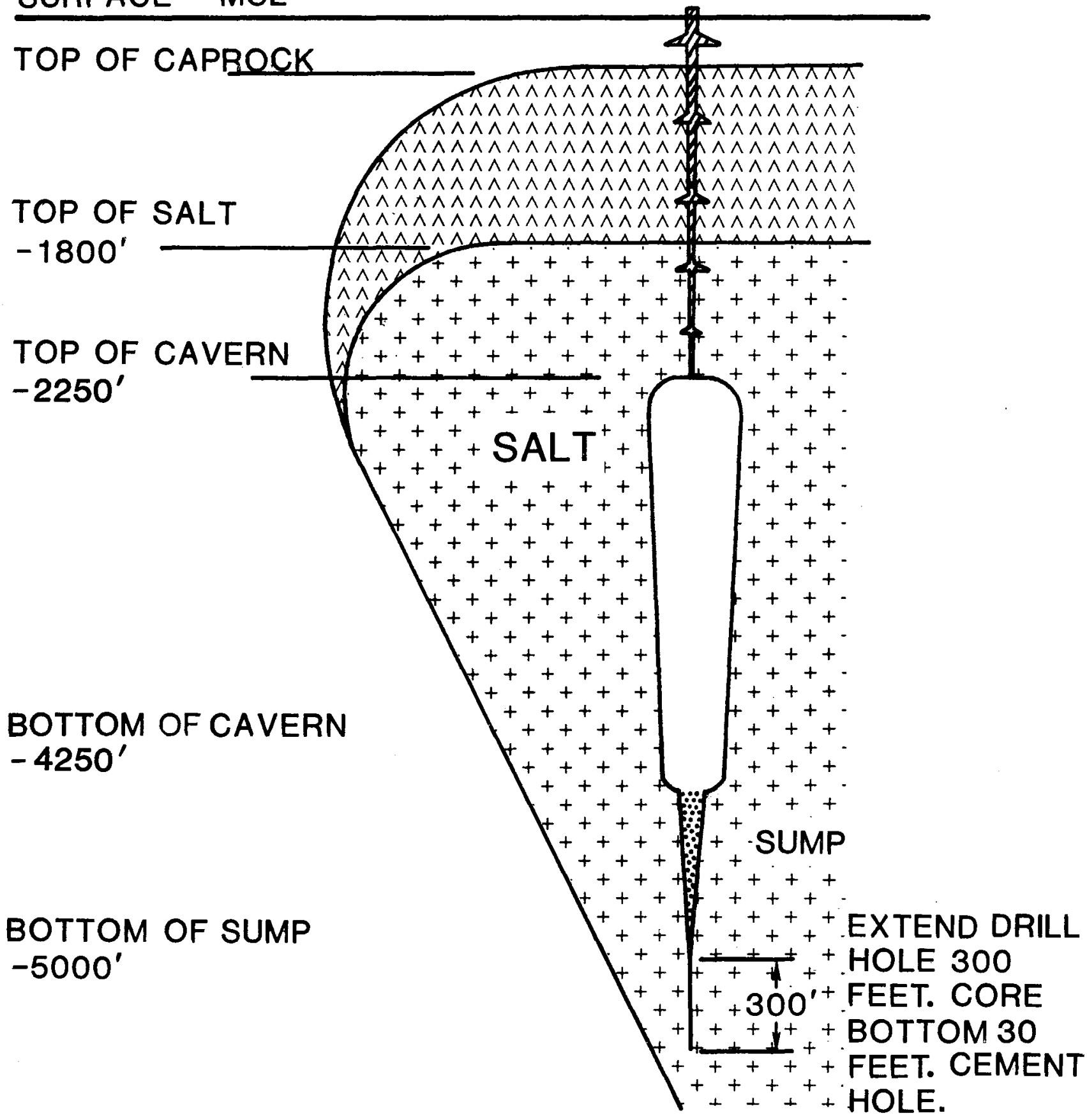

BIG HILL SALT DOME EXPLORATORY EXTENSION DRILLING 
$v$

) 
CHAPTER 7 - NATURAL HAZARDS

\author{
Subsidence
}

Ground water withdrawal has caused some minor regional subsidence (0.2 to $7 \mathrm{ft}$ ) in the Big $\mathrm{Hill}$ area (Brown, et a1, 1974). This type of subsidence will not adversely affect the SPR site. Minor subsidence because of oil withdrawal around the periphery of the dome can also be expected, but it appears unlikely to threaten SPR facilities.

The possibility of subsidence because of the formation of storage caverns has not been adequately determined. The importance of cavern spacing and roof thickness is discussed in detail in Chapter 6.

\title{
Earthquakes
}

The National Oceanic and Atmospheric Administration (NOAA) (1974) has classified the Big Hill area as having no reasonable expectancy of seismic activity (Figure 7-1). An earthquake data search by NOAA shows that no earthquakes have occurred in recorded history in the $\mathrm{Big} \mathrm{Hill}$ area (PB/KBB, 1979). The data search covered a rectangle bounded by $28^{\circ} 55^{\prime}$ to $30^{\circ} 19^{\prime}$ north latitude and $90^{\circ} 10^{\prime}$ to $95^{\circ} 45^{\prime}$ west longitude. The Big Hill SPR site is at $29^{\circ} 75^{\prime}$ north latitude and $94^{\circ} 25^{\prime}$ west longitude.

\section{Fautting}

Two types of faults occur in the Gulf Coast area of Texas. First are gravity-related growth faults that are formed by slumping and consolidation of thick sections of geosynclinal sediments. Moving along these faults is a gradual slippage generally considered aseismic.

The other type of fault relates to the growth of salt domes. Most of the faults recognized in this study have been inactive since mid-Miocene; only one fault (see Chapter 5) could be considered active. The steeper slopes of the salt dome could also indicate active faulting. Again, this type of fault movement is not seismic but rather a silent, gradual movement that will not adversely affect the SPR site. 
Floods and Hurricanes

Annual average precipitation at Big $\mathrm{Hill}$ is $\sim 47$ in. Flooding is common along the Gulf Coast of Texas in the area. A regional flood-insurance study by the Department of Housing and Urban Development (HUD, 1977) indicates that the maximum elevation of the 100-yr flood is $~ 15 \mathrm{ft}$ above ms 7 . Figure 7-2 indicates the area of the site that would be affected by the 100-yr flood.

Damage from hurricanes can result from both wind and water. Facilities, including wellheads, should be built to withstand the potential effects of hurricanes.

Figure 7-3 shows the area inundated by marine water during Hurricanes Carla in 1967 and Beulah in 1967. The maximum water elevation near Big Hill was $~ 8.6$ ft during Carla, which made landfall at Port $0^{\prime}$ Connor, Texas, 175 $\mathrm{mi}$ from the site. Maximum storm surge reported was $22 \mathrm{ft}$ above ms 1 reported at Port Lavaca (Brown, et al, 1974). Maximum high-water elevation during a hurricane in the northern hemisphere is immediately to the northeast of the eye of the hurricane because of counterclockwise winds. If a hurricane hit the coast immediately southwest of the site, the maximum high-water elevation would be somewhat higher than the maximum 100-yr non-hurricanerelated flood because of the added impact of storm surge. Maximum high water elevation during a hurricane has not yet been determined, but was estimated by Bodine (1969) as $15.3 \mathrm{ft}$ above msl. In addition, high waves added to the impact of storm surge could significantly increase the amount of flooding at Big Hill. The surface elevation at Cavern 114 is approximately 22 to $23 \mathrm{ft}$ above $\mathrm{ms}$. The remaining caverns 1 ie at an elevation $>25 \mathrm{ft} \mathrm{ms} 7$. 


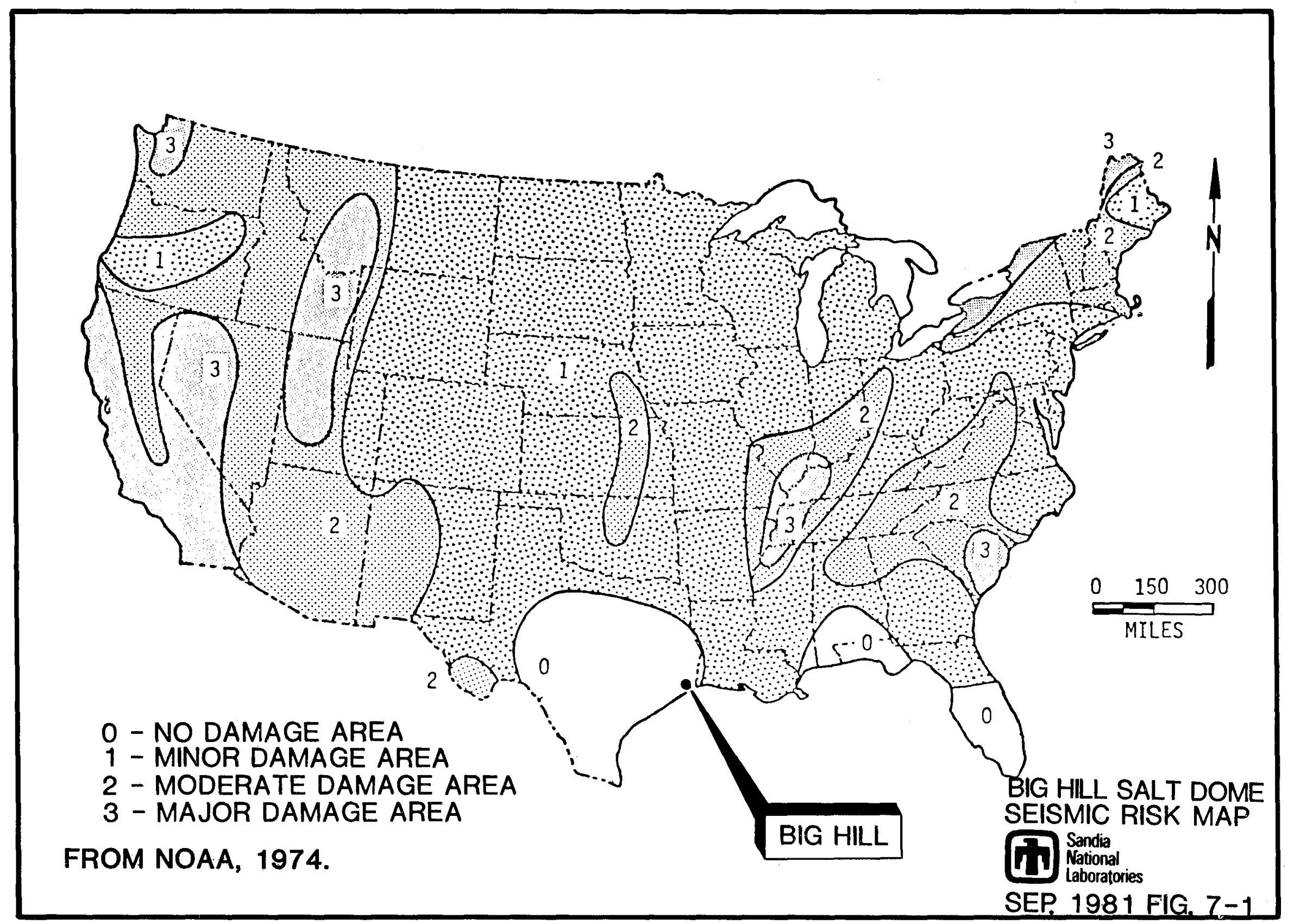




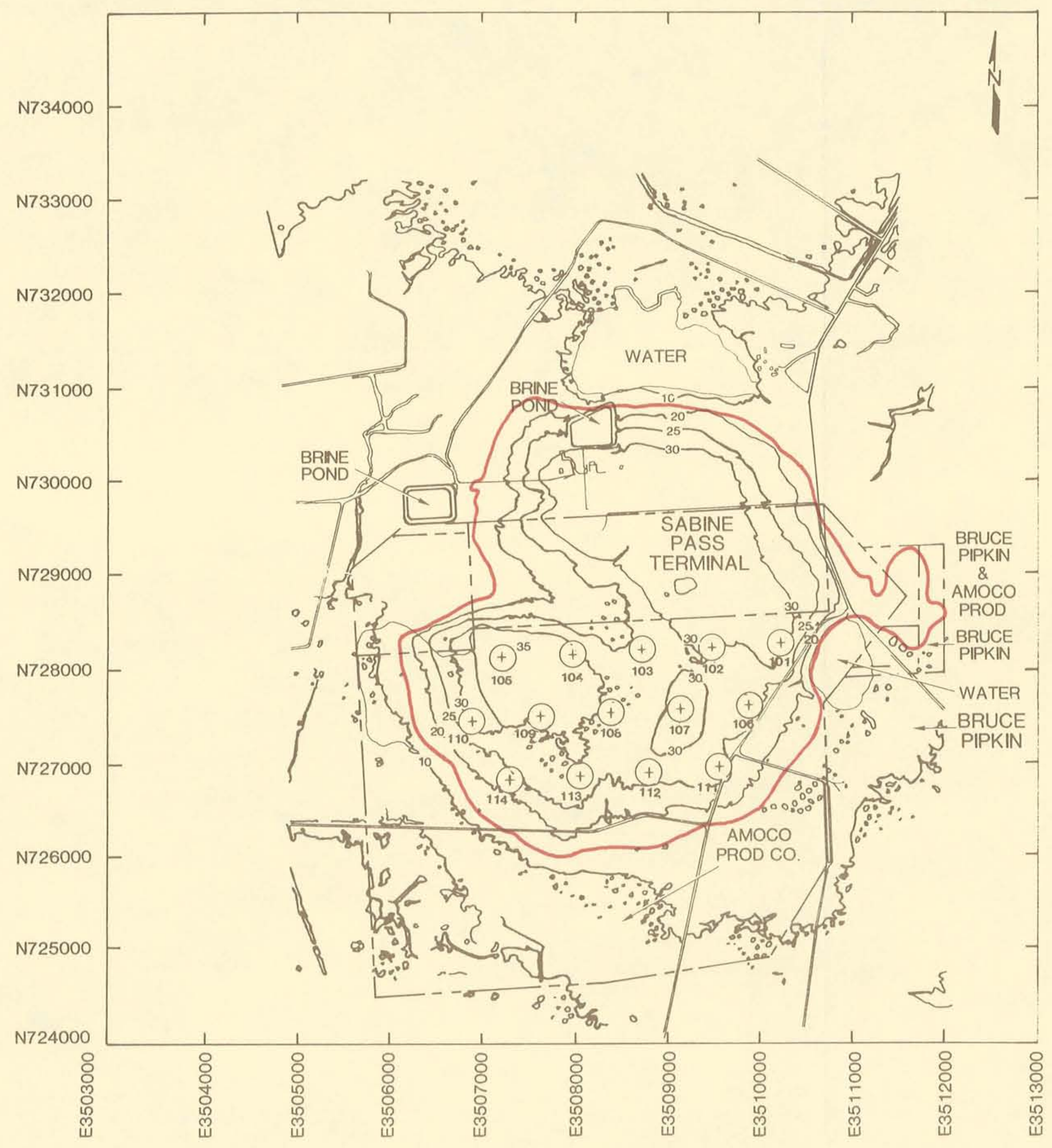

NOTE:

100 YEAR FLOOD LINE

APPROXIMATELY 15

FEET MEAN SEA LEVEL

(HUD, 1977).

LEGEND

---- PROPERTY LINE

- 5 FOOT TOPOGRAPHIC CONTOUR

100 YEAR FLOOD LINE

$1000 \quad 500 \quad 0$

1000 2000

DISTANCE IN FEET

BIG HILL SALT DOME 100 YEAR FLOOD HAZARD MAP iit National 


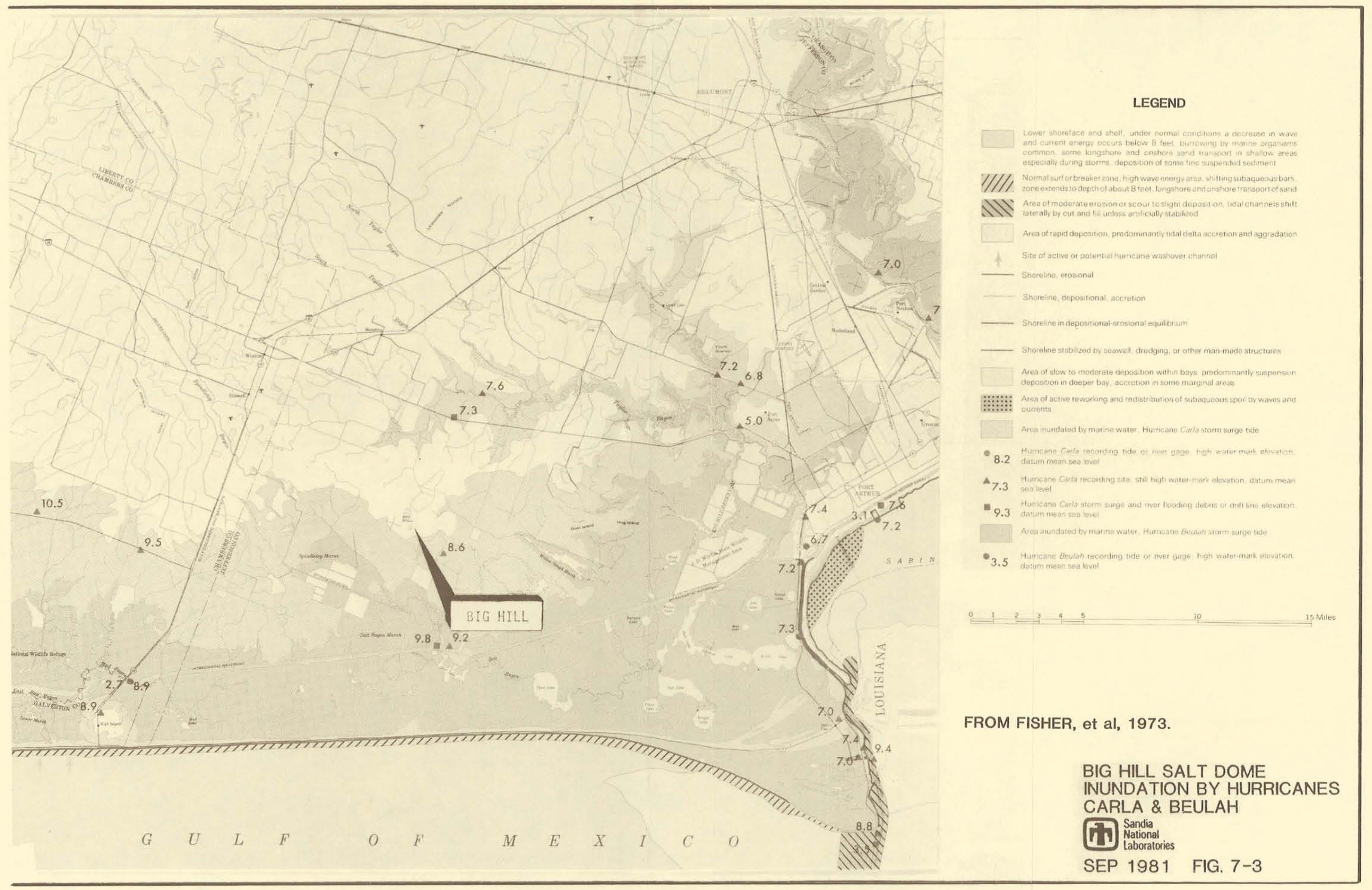


$\frac{2}{y}$
$\frac{11}{2}$
$\frac{2}{2}$ 


\section{APPENDIX A}

\section{References and Bibliography}


APPENDIX A

References and Bibliography

S. E. Benzley, Structural Analysis of West Hackberry No. 6 SPR Storage Cavern, SAND80-1904 (Albuquerque, NM: Sandia NationaT Laboratories, August 1980).

H. A. Bernard and R. J. LeBlanc, Resume of the Quaternary Geology of the Nortinestern Gulf of Mexico Province, in The Quaternary of the United States, ed H. E. Wright, Jr and D. G. Frey (Princeton: Princeton University Press, 1965, pp 137-185).

B. R. Bodine, Hurricane Surge Frequency Estimated for the Gulf Coast of Texas, Tech. Memo No. 26 (Ft Belvoir, VA: US Army Corps of Engineers, Coastal Engineerning Research Center, 1969).

L. F. Brown, R. A. Morton, J. H. McGowen, C. W. Kreitler, and W. L. Fisher, Natural Hazards of the Texas Coastal Zone (Austin, TX: University of Texas, in cooperation with Texas Coastal and Marine Council, 1974).

J. L. Crout, D. G. Symmank, and G. A. Peterson, Soil Survey of Jefferson Co, Texas, US Department of Agriculture, Soil Conservation Service, in cooperation with Texas A\&M Agr. Expt. Sta., Soil Survey Ser. No. 21 (Washington, DC: US Dept. of Agriculture, 1960).

UUE, Final Environmental Impact Statement, Strategic Petroleum Reserve, Texoma Group Salt Domes, Cameron and Calcasieu Parishes, Louisiana and Jefferson County, Texas (Washington, DC: DOE, 1978).

R. S. Dollison, Big Hill Field, Jefferson County, Texas, Trans. Gulf Coast Assoc. Geol. Soc., Vol XV, pp 25-35, 1965.

Fenix \& Scisson, Investigation of New Leached Caverns in Salt Domes, prepared for the DOE (ATbuquerque, NM: Fen ix \& Scisson, 1973).

W. L. Fisher, L. F. Brown, Jr, J. H. McGowen, and C. G. Groat, Environmental Geologic Atlas of the Texas Coastal Zone--Beaumont-Port Arthur Area (Austin, TX: Texas Bureau of Econ. Geo7., 1973).

H. N. Fisk, Geological Investigation of the Alluvial Valley of the Lower Mississippi River (Vicksburg, MI: US Army Corps of Engineers, 1944).

W. G. Gussow, Salt Diapirism, Importance of Temperature and Energy Source of Emplacement, in Diapirism and Diapirs. Amer. Assoc. Pet. Geol. Hemoir No. 8, 1968. 
M. T. Halbouty, Salt Domes, Gulf Region, United States and Mexico (2nd ed; Houston, TX: Gulf Publishing Co., 1979).

A. S. Henley, 1925, Big Hill Salt Dome, Jefferson County, Texas, Bul1. Amer. Assoc. Pet. Geol, , Vol 9, pp 590-593.

P. D. Hilton, et al, Interaction Effects of Storage Caverns in Salt, SAND790732 (Albuquerque, NM: Sandia National Laboratories, August 1980).

R. G. Hogan, ed, Strategic Petroleum Reserve (SPR) Geological Site Characterization Report, Bryan Mound Salt Dome, SAND80-7111 (ATbuquerque, NM: Sandia National Laboratories, October 1980a).

R. G. Hogan, ed, Strategic Petroleum Reserve (SPR) Geological Site Characterization Report Bayou Choctaw Dome, SAND80-7140 (A1buquerque, NM:

Sandia National Laboratories, December 1980b).

Department of Housing and Urban Development (HUD), Federal Insurance Administration, Flood Hazard Boundary Map, Jefferson County, Texas, Sheet 47 (Washington, DC: HUD, 1977).

P. H. Jones, A. N. Turcan, Jr, and H. E. Skibitzke, Geology and Ground-Water Resources of Southwestern Louisiana (Baton Rouge, LA: USGS Bu11. No. 30, 1954).

D. H. Kupfer, Boundary Shear Zones in Salt Stocks, in Fourth Symposium on Salt (Cleveland, OH: Northern Ohio Geological Society, Vol 1, pp 215-225, $\overline{1974})$.

J. D. Martinez et al, An Investigation of the Utility of Gulf Coast Salt Domes for the Storage or Disposal of Radioactive Wastes, prepared for the DOE (Baton Rouge, LA: Institute for EnvironmentaT Studies, Louisiana State University, 1978).

D. E. Munson and P. R. Dawson, Constitutive Model for the Low Temperature Creep of Salt (With Application to WIPP), SAND79-1853 (A1buquerque, NM:

Sandia ivational Laboratories, October 1979).

G. E. Murray, Geology of the Atlantic and Gulf Coastal Province of North America (New York: Harper and Brothers, 1961).

National Oceanic and Atmospheric Administration (NOAA) Earthquake History of the US, Publication 41-1 (Washington, DC: US Department of Commerce, 1974).

Memo from J. F. Ney, Sandia National Labuiatories, to E. E. Chapple, DOE SPR-PMO, Minimum Thickness of Salt Between Edge-of-Dome and Storage Caverns, March 25, 1981.

H. Ode, Rheology of Salt, in Diapirism and Diapirs, Amer. Assoc. Pet. Geol. Memoir No. 8, 1968. 
PB/KBB, Big Hill Complex, Planning Studies, Preliminary and Conceptual Design and Geotechnical Investigations, prepared for the DOE Strategic Petroleum Reserve Program under Contract DE-AC01-79RA31801 (Houston, TX: PB/KBB, August 1979).

F. W. B. Van Eysinga, Geologic Time Table (3rd ed; Amsterdam, Holland: Elsevier Scientific Publishing Co., 1975).

C. W. Walker, Nature and Origin of Caprock Overlying Gulf Coast Salt Domes, in Fourth Symposium on Salt (Cleveland, OH: Northern Ohio Geological Society, Vol 1, pp 169-195, 1974).

W. R. Wawersik, D. W. Hannum, and H. S. Lauson, Compression and Extension Data for Dome Salt from West Hackberry, LA, SAND79-0668 (A7buquerque, NM: Sandia National Laboratories, September 1980a).

W. R. Wawersik, D. W. Hannum, and H. S. Lauson, Compression and Extension Data for Dome Salt from West Hackberry, LA, SAND79-0668 (ATbuquerque, NM: Sandia National Laboratories, September 7980b).

J. B. Wesselman and S. Aronow, Ground-Water Resources of Chambers and Jefferson Counties, Texas, Report 133, prepared by the USGS in cooperation with the Texas Water Development Board (Washington, DC: USGS, 1973).

G. H. Whiting, ed, Strategic Petroleum Reserve, Geological Site Characterization, West Hackberry Salt Dome, SAND80-7131 (A1buquerque, NM: Sandia ivational Laboratories, October 1980).

Oscar WiThelm and Maurice Ewing, Geology and History of the Gulf of Mexico, Bul1. Geo1. Soc. Am., Vol 83, pp 575-600.

L. A. Wood, R. K. Gabrysch, and R. Marvin, Reconnaissance Investigation of the Ground-Water Resources of the Gulf Coast Region, Texas, Bu11. 6305 prepared by the US Geological Survey (USGS) in cooperation with the Texas Water Commission (Washington, DC: USGS, 1963). 


$$
\frac{8}{8}
$$

$\boldsymbol{\omega}$ 
APPENDIX B

Well Data

and Well Control

$B-1 / B-2$ 
Table B-1

Well Data

\begin{tabular}{|c|c|c|c|c|c|c|c|}
\hline $\begin{array}{l}\text { API } \\
\text { No. }\end{array}$ & Operator & Well ilo. & Location & $\begin{array}{l}\text { Total Depth } \\
\text { (in feet) }\end{array}$ & Result & Logs & $\begin{array}{c}\text { Date } \\
\text { Completed } \\
\end{array}$ \\
\hline 2020 & Adams \& Haggarty & Crow 1 & $\begin{array}{l}N 734500 \\
\text { E3508650 }\end{array}$ & 6238 & Abandoned & Electric & $3 / 16 / 62$ \\
\hline 2024 & Texaco & Crow 1 & $\begin{array}{l}\text { N731010 } \\
\text { E3510380 }\end{array}$ & 4604 & $\begin{array}{l}\text { 0il-cap rock } \\
\text { production }\end{array}$ & $\begin{array}{l}\text { Electric } \\
\text { directional }\end{array}$ & $3 / 27 / 51$ \\
\hline 2025 & Texaco & crow 2 & $\begin{array}{l}\text { N732170 } \\
\text { E3508640 }\end{array}$ & 5444 & Abandoned & Electric & $7 / 1 / 56$ \\
\hline 2031 & Stanolind & Pipkin A-4 & $\begin{array}{l}\text { N731580 } \\
\text { E3510210 }\end{array}$ & 5490 & Abandoned & Electric & $11 / 15 / 37$ \\
\hline 2032 & Stanolind & Pipkin $A-5$ & $\begin{array}{l}\text { N732925 } \\
\text { E3505333 }\end{array}$ & 8294 & Abandoned & & \\
\hline 2033 & & Crow 2 & $\begin{array}{l}\text { N732925 } \\
\text { E3505333 }\end{array}$ & 2600 & Abandoned & & \\
\hline 20351 & Union $0 i 1$ & LPG 1 & N729959 & 3430 & Cavern Well & & $4 / 20 / 57$ \\
\hline 20362 & Union $0 i 1$ & $L P G 2$ & $\begin{array}{l}\text { N729842 } \\
\text { E3508590 }\end{array}$ & 3203 & Cavern Well & & $5 / 9 / 61$ \\
\hline 20371 & Union $0 i 1$ & SWDW & $\begin{array}{l}\text { N729938 } \\
\text { E3507104 }\end{array}$ & 978 & Brine Disposal & Drillers & $10 / 10 / 56$ \\
\hline 2038 & $\begin{array}{l}\text { Freeport } \\
\text { Sulphur }\end{array}$ & Staiti 2 & $\begin{array}{l}\text { N728120 } \\
\text { E3507370 }\end{array}$ & 450 & $\begin{array}{l}\text { Exploratory } \\
\text { Sulphur }\end{array}$ & Drillers & $10 / 20 / 27$ \\
\hline 2039 & $\begin{array}{l}\text { Freeport } \\
\text { Sulphur }\end{array}$ & Staiti 5 & $\begin{array}{l}\text { N730420 } \\
\text { E3508080 }\end{array}$ & 700 & $\begin{array}{l}\text { Exploratory } \\
\text { Sulphur }\end{array}$ & Drillers & $12 / 15 / 27$ \\
\hline 2040 & $\begin{array}{l}\text { Freeport } \\
\text { Sulphur }\end{array}$ & Staiti 7 & $\begin{array}{l}N 728915 \\
\text { E3508080 }\end{array}$ & 527 & $\begin{array}{l}\text { Exploratory } \\
\text { Sulphur }\end{array}$ & Drillers & $1 / 2 / 28$ \\
\hline 2041 & $\begin{array}{l}\text { Freeport } \\
\text { Sulphur }\end{array}$ & Staiti 8 & $\begin{array}{l}\text { N729768 } \\
\text { E3510217 }\end{array}$ & 610 & $\begin{array}{l}\text { Exploratory } \\
\text { Sulphur }\end{array}$ & Drillers & $1 / 16 / 28$ \\
\hline 2042 & $\begin{array}{l}\text { Freeport } \\
\text { Sulphur }\end{array}$ & Staiti 10 & $\begin{array}{l}E 3510315 \\
E 3510315\end{array}$ & 510 & $\begin{array}{l}\text { Exploratory } \\
\text { Sulphur }\end{array}$ & Drillers & $2 / 9 / 28$ \\
\hline 2043 & Guffey & Broussard G-1 & $\begin{array}{l}N 727900 \\
3510509\end{array}$ & 1400 & Abandoned & & \\
\hline 2044 & Texaco & Masterson 1 & $\begin{array}{l}\text { N730679 } \\
\text { E3510760 }\end{array}$ & 4435 & Abandoned & & $11 / 21 / 51$ \\
\hline 2045 & Texaco & Masterson 2 & $\begin{array}{l}\text { N730569 } \\
\text { E3511230 }\end{array}$ & 4697 & Abandoned & Electric & $6 / 16 / 53$ \\
\hline 2047 & & Crow 1 & $\begin{array}{l}\text { N737465 } \\
\text { E3517700 }\end{array}$ & 1153 & Abandoned & & \\
\hline 2775 & $\begin{array}{l}\text { Pan Am } \\
\text { (Stanolind) }\end{array}$ & Davidson 1 & $\begin{array}{l}\text { N734220 } \\
\text { E3507610 }\end{array}$ & 10774 & Abandoned & Electric & $5 / 1 / 42$ \\
\hline 2776 & McCarthy & Davidson $1 \mathrm{E}$ & $\begin{array}{l}N 730670 \\
E 3504660\end{array}$ & 8457 & Gas & Electric & $12 / 9 / 55$ \\
\hline 2787 & Adams \& Haggarty & $\begin{array}{l}\text { Marrs } \\
\text { McLean } 11\end{array}$ & $\begin{array}{l}\text { N730121 } \\
\text { E3505652 }\end{array}$ & 5650 & Abandoned & Electric & $5 / 23 / 55$ \\
\hline 2789 & Adams \& Haggarty & $\begin{array}{l}\text { Marrs } \\
\text { McLean } 13\end{array}$ & $\begin{array}{l}\text { N729654 } \\
\text { E3504787 }\end{array}$ & 5932 & Abandoned & Electric & $8 / 22 / 61$ \\
\hline 2790 & Adams \& Haggarty & $\begin{array}{l}\text { Marrs } \\
\text { McLean } 15\end{array}$ & $\begin{array}{l}\text { N729596 } \\
\text { E3504782 }\end{array}$ & 6670 & $0 i 1$ & Electric & $10 / 25 / 61$ \\
\hline 2791 & Adams \& Haggarty & $\begin{array}{l}\text { Marrs } \\
\text { Mclean } 16\end{array}$ & $\begin{array}{l}\text { N729120 } \\
\text { E3502640 }\end{array}$ & 7824 & $0 i 1$ & Electric & $4 / 23 / 62$ \\
\hline 2792 & Adams \& Haggarty & $\begin{array}{l}\text { Marrs } \\
\text { McLean } 17\end{array}$ & $\begin{array}{l}N 729455 \\
E 3505391\end{array}$ & 7982 & $0 i 1$ & Electric & $10 / 9 / 62$ \\
\hline 2793 & Adams \& Haggarty & $\begin{array}{l}\text { Marrs } \\
\text { McLean } 18\end{array}$ & $\begin{array}{l}\text { N729479 } \\
\text { E3505391 }\end{array}$ & 1550 & $0 i 1$ & Electric & $10 / 79 / 62$ \\
\hline
\end{tabular}


Table B-1

(Cont)

\begin{tabular}{|c|c|c|c|c|c|c|c|}
\hline $\begin{array}{l}\text { API } \\
\text { No. } \\
\end{array}$ & Operator & Well No. & Location & $\begin{array}{l}\text { Total Depth } \\
\text { (in feet) }\end{array}$ & Result & Logs & $\begin{array}{c}\text { Date } \\
\text { Completed } \\
\end{array}$ \\
\hline 2796 & Adams \& Haggarty & Pan Am 1 & $\begin{array}{l}\text { N728780 } \\
\text { E3505723 }\end{array}$ & 5500 & $0 i 1$ & Electric & $10 / 7 / 62$ \\
\hline 2797 & $\begin{array}{l}\text { Freeport } \\
\text { Sulphur }\end{array}$ & Staiti 3 & $\begin{array}{l}\text { N7291112 } \\
\text { E3506376 }\end{array}$ & 1416 & $\begin{array}{l}\text { Exploratory } \\
\text { Sulphur }\end{array}$ & Drillers & $11 / 24 / 27$ \\
\hline 2803 & Adams \& Haggarty & Fitzhugh 10 & $\begin{array}{l}N 728240 \\
\text { E3505031 }\end{array}$ & 6153 & $0 i 1$ & Electric & $7 / 25 / 61$ \\
\hline 2805 & Adams \& Haggarty & Fitzhugh 12 & $\begin{array}{l}\text { N728843 } \\
\text { E3505269 }\end{array}$ & 5761 & $0 i 1$ & Electric & $4 / 30 / 62$ \\
\hline 2824 & $\begin{array}{l}\text { Freeport } \\
\text { Sulphur }\end{array}$ & Staiti 11 & $\begin{array}{l}\text { N726652 } \\
\text { E3506184 }\end{array}$ & 1347 & $\begin{array}{l}\text { Exploratory } \\
\text { Sulphur }\end{array}$ & Drillers & $2 / 28 / 28$ \\
\hline 2829 & Pan Am & Fitzhugh 5 & $\begin{array}{l}\text { N726095 } \\
\text { E3504860 }\end{array}$ & 8500 & Abandoned & Electric & $2 / 19 / 43$ \\
\hline 2835 & Jayred & Fitzhugh 9 & $\begin{array}{l}N 723970 \\
\text { E3505632 }\end{array}$ & 6615 & Abandoned & Electric & $8 / 15 / 62$ \\
\hline 2837 & Pan Am & Fitzhugh 3 & $\begin{array}{l}\text { N721470 } \\
\text { E3505920 }\end{array}$ & 8031 & Abandoned & Electric & $7 / 10 / 42$ \\
\hline 2870 & $\begin{array}{l}\text { Texas } \\
\text { Exploration }\end{array}$ & Broussard 1 & $\begin{array}{l}N 727320 \\
E 3507450\end{array}$ & 482 & Abandoned & Drillers & $7 / 27 / 17$ \\
\hline 2871 & $\begin{array}{l}\text { Texas } \\
\text { Exploration }\end{array}$ & Broussard 2 & $\begin{array}{l}N 726445 \\
\text { E3508543 }\end{array}$ & 548 & Abandoned & Drillers & $10 / 10 / 17$ \\
\hline 2872 & $\begin{array}{l}\text { Texas } \\
\text { Exploration }\end{array}$ & Broussard 3 & $\begin{array}{l}N 725400 \\
\text { E3507500 }\end{array}$ & 1200 & Abandoned & Drillers & $1 / 3 / 18$ \\
\hline 2873 & $\begin{array}{l}\text { Texas Exploration } \\
\text { Staiti }\end{array}$ & Broussard 4 & $\begin{array}{l}\text { N725000 } \\
\text { E3507375 }\end{array}$ & 1358 & Abandoned & Drillers & $8 / 5 / 18$ \\
\hline 2874 & $\begin{array}{l}\text { Freeport } \\
\text { Sulphur }\end{array}$ & Staiti 1 & $\begin{array}{l}N 727412 \\
\text { E3508080 }\end{array}$ & 656 & $\begin{array}{l}\text { Exploratory } \\
\text { Sulphur }\end{array}$ & Drillers & $10 / 24 / 27$ \\
\hline $287 i$ & $\begin{array}{l}\text { Freeport } \\
\text { Sulphur }\end{array}$ & Staiti 4 & $\begin{array}{l}\text { N7265568 } \\
\text { E3508930 }\end{array}$ & 1041 & $\begin{array}{l}\text { Exploratory } \\
\text { Sulphur }\end{array}$ & Drillers & $12 / 07 / 27$ \\
\hline $287 b^{\circ}$ & $\begin{array}{l}\text { Freeport } \\
\text { Sulphur }\end{array}$ & Staiti 6 & $\begin{array}{l}\text { N725589 } \\
\text { E3509920 }\end{array}$ & 1153 & $\begin{array}{l}\text { Exploratory } \\
\text { Sulphur }\end{array}$ & Drillers & $1 / 18 / 28$ \\
\hline 2877 & $\begin{array}{l}\text { Freeport } \\
\text { Sulphur }\end{array}$ & Staiti 9 & $\begin{array}{l}N 725638 \\
\text { E3509892 }\end{array}$ & 1295 & Exploratory & Drillers & $2 / 19 / 28$ \\
\hline 2878 & Houston $0 i 1$ & Staiti 1 & $\begin{array}{l}\text { N725892 } \\
\text { E3510650 }\end{array}$ & 1559 & Abandoned & Drillers & $11 / 07 / 23$ \\
\hline 2879 & Houston $0 i 1$ & Staiti 2 & $\begin{array}{l}\text { N725554 } \\
\text { E3510426 }\end{array}$ & 1634 & Abandoned & Drillers & $6 / 29 / 23$ \\
\hline 2881 & $\begin{array}{l}\text { Chance \& } \\
\text { Caldwe11 }\end{array}$ & Fitzhugh 1 & $\begin{array}{l}\text { N724465 } \\
\text { E3508068 }\end{array}$ & 1828 & Abandoned & Electric & $6 / 19 / 45$ \\
\hline 2882 & $\begin{array}{l}\text { Chance \& } \\
\text { Caldwel1 }\end{array}$ & Fitzhugh 2-A & $\begin{array}{l}N 724445 \\
\text { E3507700 }\end{array}$ & 1720 & Abandoned & Electric & $11 / 16 / 45$ \\
\hline 2883 & $\begin{array}{l}\text { Chance \& } \\
\text { Caldwe11 }\end{array}$ & Fitzhugh 1-B & $\begin{array}{l}N 724582 \\
\text { E3508263 }\end{array}$ & 1669 & Abandoned & Electric & $10 / 07 / 45$ \\
\hline 2884 & $\begin{array}{l}\text { Stanolind } \\
011\end{array}$ & Fitzhugh 1. & $\begin{array}{l}\text { N724500 } \\
\text { E35088379 }\end{array}$ & 5572 & $0 i 1$ & Electric & $3 / 04 / 37$ \\
\hline 2885 & $\begin{array}{l}\text { Stanolind } \\
0 i 1\end{array}$ & Fitzhugh 2 & $\begin{array}{l}\text { N724452 } \\
\text { E3507775 }\end{array}$ & 4705 & Abandoned & Electric & $11 / 01 / 37$ \\
\hline 2887 & $\begin{array}{l}\text { Bering Co } \\
\text { (Wynne) }\end{array}$ & Fitzhugh $1-A$ & $\begin{array}{l}\text { N723970 } \\
\text { E3509004 }\end{array}$ & 5540 & $0 i 1$ & Electric & $11 / 17 / 49$ \\
\hline 2890 & $\begin{array}{l}\text { Bering Co. } \\
\text { (Wynne) }\end{array}$ & Fitzhugh 4 & $\begin{array}{l}\text { N724444 } \\
\text { E3509059 }\end{array}$ & 5101 & Abandoned & Electric & $12 / 04 / 50$ \\
\hline 2892 & Texaco & Fitzhugh 2 & $\begin{array}{l}\text { N724552 } \\
\text { E3510054 }\end{array}$ & 2922 & Abandoned & & $3 / 20 / 20$ \\
\hline
\end{tabular}


Table B-T

(Cont)

\begin{tabular}{|c|c|c|c|c|c|c|c|}
\hline $\begin{array}{l}\text { API } \\
\text { No. }\end{array}$ & Operator & Wel1 No. & Location & $\begin{array}{l}\text { Total Depth } \\
\text { (in feet) } \\
\end{array}$ & Result & Logs & $\begin{array}{c}\text { Date } \\
\text { Completed } \\
\end{array}$ \\
\hline 2907 & Stanolind $0 i 1$ & McFadd in $A-3$ & $\begin{array}{l}\text { N726260 } \\
\text { E3512350 }\end{array}$ & 6698 & Abandoned & Electric & $8 / 17 / 36$ \\
\hline 2909 & Pan Am & Pipkin 2-B & $\begin{array}{l}\text { N725143 } \\
\text { E3510490 }\end{array}$ & 6414 & Abandoned & Electric & $8 / 78 / 37$ \\
\hline 2914 & Texaco & Pipkin 6 & $\begin{array}{l}\text { N725630 } \\
\text { E3512270 }\end{array}$ & 8800 & Abandoned & Electric & $4 / 06 / 53$ \\
\hline 2915 & Texaco & Pipkin 7 & $\begin{array}{l}\text { N726850 } \\
\text { E3511441 }\end{array}$ & 5254 & Abandoned & Electric & $8 / 28 / 53$ \\
\hline 2976 & Texaco & Pipkin 8 & $\begin{array}{l}\text { N727010 } \\
\text { E3511520 }\end{array}$ & 4829 & Abandoned & Electric & $1 / 15 / 54$ \\
\hline 3072 & Sunset & Anderson 1 & $\begin{array}{l}\text { N7311180 } \\
\text { E3506450 }\end{array}$ & 1437 & Abandoned & Electric & $7 / 22 / 64$ \\
\hline 3073 & Sunset & Anderson 2 & $\begin{array}{l}\text { N731780 } \\
\text { E3506080 }\end{array}$ & 7913 & $0 i 1$ & Electric & $8 / 29 / 64$ \\
\hline 3079 & Goodale & Pan Am 1 & $\begin{array}{l}\text { N724760 } \\
\text { E3506219 }\end{array}$ & 5995 & $0 i 1$ & Electric & $8 / 19 / 64$ \\
\hline 3091 & HNG & Davidson $2 E$ & $\begin{array}{l}\text { N730710 } \\
\text { E3505280 }\end{array}$ & 6000 & Abandoned & Electric & $11 / 79 / 64$ \\
\hline 3093 & $\begin{array}{l}\text { Goodale } \\
\text { Bertman }\end{array}$ & Pan Am 2 & $\begin{array}{l}\text { N725060 } \\
\text { E3506140 }\end{array}$ & 5677 & $0 i 1$ & Electric & $10 / 29 / 64$ \\
\hline 3094 & Jayred & Fitzhugh 10 & $\begin{array}{l}\text { N724385 } \\
\text { E3506577 }\end{array}$ & 5800 & $0 i 1$ & Electric & $11 / 11 / 64$ \\
\hline 3721 & Gulf & Anderson 1 & $\begin{array}{l}\text { N7231980 } \\
\text { E3507080 }\end{array}$ & 5576 & Abandoned & Electric & $3 / 7 / 65$ \\
\hline 3128 & Goodale & Pan Am 3 & $\begin{array}{l}\text { N725098 } \\
\text { E3506169 }\end{array}$ & 1463 & $0 i 1$ & Electric & $12 / 21 / 64$ \\
\hline 3129 & Goodale & Pan Am 4 & $\begin{array}{l}\text { N724700 } \\
\text { E3506681 }\end{array}$ & 4802 & $0 i 1$ & Electric & $1 / 7 / 65$ \\
\hline 3730 & Pan Am & $\begin{array}{l}\text { Texas } \\
\text { Exploration } 1\end{array}$ & $\begin{array}{l}\text { N725067 } \\
\text { E3506615 }\end{array}$ & 5500 & $0 i 1$ & Electric & $4 / 76 / 65$ \\
\hline 3131 & $\begin{array}{l}\text { Goodale } \\
\text { Bertman }\end{array}$ & Pan Am 5 & $\begin{array}{l}\text { N725363 } \\
\text { E3506039 }\end{array}$ & 5413 & $0 i 1$ & Electric & $4 / 14 / 65$ \\
\hline 3732 & $\begin{array}{l}\text { Goodale } \\
\text { Bertman }\end{array}$ & Pan Am 6 & $\begin{array}{l}\text { N725363 } \\
\text { E3506053 }\end{array}$ & 2583 & $0 i 1$ & Electric & $3 / 74 / 65$ \\
\hline 3733 & Jayred & Fitzhugh 11 & $\begin{array}{l}\text { N725020 } \\
\text { E3305730 }\end{array}$ & 5650 & Abandoned & Electric & $1 / 9 / 65$ \\
\hline 3160 & $\begin{array}{l}\text { Goodale } \\
\text { Bertman }\end{array}$ & $\begin{array}{l}\text { Texas } \\
\text { Exploration } 7\end{array}$ & $\begin{array}{l}\text { N725708 } \\
\text { E3506148 }\end{array}$ & 2600 & SWLW & Electric & $5 / 20 / 65$ \\
\hline 3180 & $\begin{array}{l}\text { Goodale } \\
\text { Bertman }\end{array}$ & $\begin{array}{l}\text { Texas } \\
\text { Exploration } 10\end{array}$ & $\begin{array}{l}\text { N725645 } \\
\text { E3505858 }\end{array}$ & 5045 & $0 i 1$ & & $12 / 70 / 65$ \\
\hline 3781 & $\begin{array}{l}\text { Goodale } \\
\text { Bertman }\end{array}$ & $\begin{array}{l}\text { Texas } \\
\text { Exploration } 9\end{array}$ & $\begin{array}{l}N 724755 \\
\text { E3506560 }\end{array}$ & 4524 & $0 i 1$ & Electric & $10 / 22 / 65$ \\
\hline 3215 & $\begin{array}{l}\text { Goodale } \\
\text { Bertman }\end{array}$ & $\begin{array}{l}\text { Texas } \\
\text { Exploraton } 11\end{array}$ & $\begin{array}{l}\text { N725921 } \\
\text { E3도. } 5852\end{array}$ & 5000 & $0 \nmid 1$ & Electric & $4 / 15 / 66$ \\
\hline 3216 & $\begin{array}{l}\text { Goodale } \\
\text { Bertman }\end{array}$ & Fitzhugh TAST & $\begin{array}{l}\text { N726015 } \\
\text { E3505676 }\end{array}$ & 5149 & $0 i 1$ & Electric & $3 / 18 / 66$ \\
\hline 3225 & $\begin{array}{l}\text { Goodale } \\
\text { Bertman }\end{array}$ & Fitzhugh 1-B & $\begin{array}{l}\text { N724480 } \\
\text { E3506700 }\end{array}$ & 4800 & $0 i 1$ & Electric & $5 / 9 / 66$ \\
\hline 3236 & $\begin{array}{l}\text { Goodale } \\
\text { Bertman }\end{array}$ & Fitzhugh 2-A & $\begin{array}{l}\text { N726278 } \\
\text { E3505525 }\end{array}$ & 5323 & $0 j]$ & Electric & $7 / 2 / 66$ \\
\hline
\end{tabular}


Table B-1

(Cont)

\begin{tabular}{|c|c|c|c|c|c|c|c|}
\hline $\begin{array}{l}\text { API } \\
\text { No. }\end{array}$ & Operator & Well No. & Location & $\begin{array}{l}\text { Total Depth } \\
\text { (in feet) }\end{array}$ & Result & Logs & $\begin{array}{c}\text { Date } \\
\text { Completed } \\
\end{array}$ \\
\hline 3237 & $\begin{array}{l}\text { Goodale } \\
\text { Bertman }\end{array}$ & Fitzhugh 3-A & $\begin{array}{l}\text { N726610 } \\
\text { E3504910 }\end{array}$ & 6149 & Abandoned & Electric & $7 / 19 / 66$ \\
\hline 3238 & $\begin{array}{l}\text { Goodale } \\
\text { Bertman }\end{array}$ & $\begin{array}{l}\text { Texas } \\
\text { Exploration } 13\end{array}$ & $\begin{array}{l}N 727085 \\
\text { E3505957 }\end{array}$ & 1912 & Abandoned & Electric & $8 / 26 / 66$ \\
\hline 3239 & $\begin{array}{l}\text { Goodale } \\
\text { Bertman }\end{array}$ & Fitzhugh $4-A$ & $\begin{array}{l}\text { N725230 } \\
\text { E3505644 }\end{array}$ & 5562 & Abandoned & Electric & $8 / 18 / 66$ \\
\hline 3244 & $\begin{array}{l}\text { Goodale } \\
\text { Bertman }\end{array}$ & Fitzhugh 5-A & $\begin{array}{l}\text { N725630 } \\
\text { E3505700 }\end{array}$ & 5200 & Abandoned & Electric & $10 / 24 / 66$ \\
\hline 3257 & Pan Am & $\begin{array}{l}\text { Texas } \\
\text { Exploration } 2\end{array}$ & $\begin{array}{l}\text { N725245 } \\
\text { E3506603 }\end{array}$ & 7111 & $0 i 1$ & Electric & $1 / 25 / 67$ \\
\hline 3265 & Pan Am & $\begin{array}{l}\text { Texas } \\
\text { Exploration } 4\end{array}$ & $\begin{array}{l}\text { N725540 } \\
\text { E3510112 }\end{array}$ & 5025 & $0 i 1$ & Electric & $3 / 6 / 67$ \\
\hline 3266 & Pan Am & $\begin{array}{l}\text { Texas } \\
\text { Exploration } 3\end{array}$ & $\begin{array}{l}\text { N725458 } \\
\text { E3506779 }\end{array}$ & 4900 & $0 i 1$ & Electric & $3 / 24 / 67$ \\
\hline 3267 & Pan Am & $\begin{array}{l}\text { Texas } \\
\text { Exploration } 5\end{array}$ & $\begin{array}{l}\text { N726070 } \\
\text { E3510390 }\end{array}$ & 4653 & Abandoned & Electric & $3 / 29 / 67$ \\
\hline 3269 & $\begin{array}{l}\text { Goodale } \\
\text { Bertman }\end{array}$ & $\begin{array}{l}\text { Fitzhugh 2B } \\
\text { (was TX Exp 12) }\end{array}$ & $\begin{array}{l}\text { N726151 } \\
\text { E3505598 }\end{array}$ & 4273 & Abandoned & Scout Ticket & $2 / 20 / 67$ \\
\hline 3272 & Pan Am & $\begin{array}{l}\text { Texas } \\
\text { Exploration } 8\end{array}$ & $\begin{array}{l}\text { N727497 } \\
\text { E3505768 }\end{array}$ & 5200 & Abandoned & Electric & $4 / 26 / 67$ \\
\hline 3274 & $\begin{array}{l}\text { Goodale } \\
\text { Bertman }\end{array}$ & Fitzhugh 2-B & $\begin{array}{l}\text { N724507 } \\
\text { E3509519 }\end{array}$ & 5393 & Abandoned & Electric & $5 / 8 / 67$ \\
\hline 3282 & Pan Am & $\begin{array}{l}\text { Texas } \\
\text { Exploration } 7\end{array}$ & $\begin{array}{l}\text { N725307 } \\
\text { E3506996 }\end{array}$ & 4687 & 011 & Electric & $5 / 27 / 67$ \\
\hline 3284 & $\begin{array}{l}\text { Goodale } \\
\text { Bertman }\end{array}$ & $\begin{array}{l}\text { Texas } \\
\text { Exploration } 14\end{array}$ & $\begin{array}{l}\text { N725390 } \\
\text { E3506229 }\end{array}$ & 1618 & Abandoned & & \\
\hline 3289 & $\begin{array}{l}\text { Goodale } \\
\text { Bertman }\end{array}$ & $\begin{array}{l}\text { Texas } \\
\text { Explaration } 15\end{array}$ & $\begin{array}{l}\text { N725271 } \\
\text { E3506068 }\end{array}$ & 4265 & 011 & Electric & $6 / 26 / 67$ \\
\hline 3290 & Pan Am & $\begin{array}{l}\text { Texas } \\
\text { Exploration } 9\end{array}$ & $\begin{array}{l}\text { N725096 } \\
\text { E3506815 }\end{array}$ & 5000 & $0 i 1$ & Electric & $7 / 1 / 67$ \\
\hline 3295 & $\begin{array}{l}\text { Goodale } \\
\text { Bertman }\end{array}$ & $\begin{array}{l}\text { Texas } \\
\text { Exploration } 16\end{array}$ & $\begin{array}{l}\text { N725271 } \\
\text { E3506093 }\end{array}$ & 5202 & $0 i 1$ & Electric & $7 / 26 / 67$ \\
\hline 3297 & Pan Am & $\begin{array}{l}\text { Texas } \\
\text { Exploration } 10\end{array}$ & $\begin{array}{l}\text { N725607 } \\
\text { E3506571 }\end{array}$ & 6200 & $0 i 1$ & Electric & $8 / 11 / 67$ \\
\hline 3299 & $\begin{array}{l}\text { Goodale } \\
\text { Bertman }\end{array}$ & $\begin{array}{l}\text { Texas } \\
\text { Exploration } 7\end{array}$ & $\begin{array}{l}\text { N724665 } \\
\text { E3506731 }\end{array}$ & 4925 & $0 i 1$ & Electric & $8 / 19 / 67$ \\
\hline 3303 & Pan Am & $\begin{array}{l}\text { Texas } \\
\operatorname{Exp} 11 \text { (ST) }\end{array}$ & $\begin{array}{l}\text { N728850 } \\
\text { E3506055 }\end{array}$ & 5066 & Abandoned & Electric & $9 / 7 / 67$ \\
\hline 3305 & Pan Am & $\begin{array}{l}\text { Texas } \\
\text { Exploration } 12\end{array}$ & $\begin{array}{l}\text { N725189 } \\
\text { E3507164 }\end{array}$ & 4451 & $0 i 1$ & Scout Ticket & $9 / 1 / 67$ \\
\hline 3308 & $\begin{array}{l}\text { Goodale } \\
\text { Bertman }\end{array}$ & $\begin{array}{l}\text { Texas } \\
\text { Exploration } 18\end{array}$ & $\begin{array}{l}\text { N725482 } \\
\text { E3505974 }\end{array}$ & 5100 & $0 i 1$ & Electric & $9 / 15 / 67$ \\
\hline 3309 & Pan Am & $\begin{array}{l}\text { Texas } \\
\text { Exploration } 14\end{array}$ & $\begin{array}{l}N 725010 \\
\text { E3507052 }\end{array}$ & 4400 & $0 i 1$ & Electric & $9 / 25 / 67$ \\
\hline 3318 & Pan Am & $\begin{array}{l}\text { Texas } \\
\text { Exploratio } 13\end{array}$ & $\begin{array}{l}\text { N728518 } \\
\text { E3511209 }\end{array}$ & 4464 & Abandoned & Electric & $11 / 10 / 67$ \\
\hline 3319 & $\begin{array}{l}\text { Goodale } \\
\text { Bertman }\end{array}$ & $\begin{array}{l}\text { Texas } \\
\text { Exploration } 19\end{array}$ & N725647 & 4712 & $0 i 1$ & $\begin{array}{l}\text { Electric } \\
\text { Gamma ray }\end{array}$ & $11 / 4 / 67$ \\
\hline 3322 & Pan Am & $\begin{array}{l}\text { Texas } \\
\text { Exploration } 15\end{array}$ & $\begin{array}{l}N 725150 \\
E 3507363\end{array}$ & 4050 & $0 I]$ & Electric & $11 / 4 / 67$ \\
\hline 3324 & $\begin{array}{l}\text { Goodale } \\
\text { Bertman }\end{array}$ & $\begin{array}{l}\text { Texas } \\
\text { Exploration } 20\end{array}$ & $\begin{array}{l}\text { N724622 } \\
\text { E3506980 }\end{array}$ & 4549 & $0 i 1$ & Electric & $12 / 15 / 67$ \\
\hline
\end{tabular}


Table B-1

(Cont)

\begin{tabular}{|c|c|c|c|c|c|c|c|}
\hline $\begin{array}{l}\text { API } \\
\text { No. }\end{array}$ & Operator & Well No. & Location & $\begin{array}{l}\text { Total Depth } \\
\text { (in feet) } \\
\end{array}$ & Result & Logs & $\begin{array}{c}\text { Date } \\
\text { Completed } \\
\end{array}$ \\
\hline 3328 & Pan Am & $\begin{array}{l}\text { Texas } \\
\text { Exploration } 16\end{array}$ & $\begin{array}{l}\text { N725452 } \\
\text { E3506940 }\end{array}$ & 4006 & $0 i 1$ & Electric & $12 / 5 / 67$ \\
\hline 3338 & Pan Am & $\begin{array}{l}\text { Texas } \\
\text { Exploration } 18\end{array}$ & $\begin{array}{l}\text { N725052 } \\
\text { E3507536 }\end{array}$ & 4000 & $0 i 7$ & Electric & $1 / 22 / 68$ \\
\hline 3340 & Pan Am & $\begin{array}{l}\text { Texas } \\
\text { Exploration } 17\end{array}$ & $\begin{array}{l}\text { N726270 } \\
\text { E3505951 }\end{array}$ & 4688 & $\begin{array}{l}0 i 1 \text { now } \\
\text { Salt water } \\
\text { disposal }\end{array}$ & Electric & $1 / 24 / 23$ \\
\hline 3346 & Pan Am & Pipkin Crow & $\begin{array}{l}\text { N731950 } \\
\text { E3508750 }\end{array}$ & 4728 & Abandoned & Electric & $2 / 28 / 68$ \\
\hline 3354 & $\begin{array}{l}\text { Goodall } \\
\text { Bertman }\end{array}$ & $\begin{array}{l}\text { Texas } \\
\text { Exploration } 21\end{array}$ & $\begin{array}{l}\text { N724882 } \\
\text { E3507323 }\end{array}$ & 4504 & $0 i 1$ & $\begin{array}{l}\text { Electric } \\
\text { Gamma ray }\end{array}$ & $4 / 13 / 68$ \\
\hline 3355 & Pan Am & $\begin{array}{l}\text { Texas } \\
\text { Exploration } 19\end{array}$ & $\begin{array}{l}\text { N726479 } \\
\text { E3505850 }\end{array}$ & 4300 & $\begin{array}{l}\text { Salt water } \\
\text { disposal }\end{array}$ & Electric & $4 / 24 / 68$ \\
\hline 3359 & $\begin{array}{l}\text { Goodale } \\
\text { Bertman }\end{array}$ & $\begin{array}{l}\text { Texas } \\
\text { Exploration } 22 \mathrm{E}\end{array}$ & $\begin{array}{l}\text { N72579] } \\
\text { E3506330 }\end{array}$ & 4040 & $0 i 1$ & Gamma ray & $5 / 18 / 68$ \\
\hline 3363 & $\begin{array}{l}\text { Goodale } \\
\text { Bertman }\end{array}$ & Fitzhugh 8-A & $\begin{array}{l}N 725450 \\
E 3504000\end{array}$ & 6730 & $0 i 1$ & Electric & $6 / 23 / 68$ \\
\hline 3376 & HNG & Davidson 3-E & $\begin{array}{l}\text { N7 32500 } \\
\text { E3504700 }\end{array}$ & 7003 & Abandoned & Electric & $8 / 6 / 68$ \\
\hline 3381 & $\begin{array}{l}\text { Goodale } \\
\text { Bertman }\end{array}$ & Fitzhugh 9-A & $\begin{array}{l}\text { N725300 } \\
\text { E3504300 }\end{array}$ & 6457 & Abandoned & Electric & $9 / 3 / 68$ \\
\hline 30031 & Pan Am & $\begin{array}{l}\text { Texas } \\
\text { Exploration } 20\end{array}$ & $\begin{array}{l}N 725143 \\
\text { E3510081 }\end{array}$ & 5054 & $0 i 1$ & Electric & $3 / 30 / 69$ \\
\hline 30032 & Pan Am & $\begin{array}{l}\text { Texas } \\
\text { Exploration } 21\end{array}$ & $\begin{array}{l}\text { N725232 } \\
\text { E3509449 }\end{array}$ & 4435 & Abandoned & Electric & $7 / 18 / 69$ \\
\hline 30138 & Amoco & $\begin{array}{l}\text { Texas } \\
\text { Exploration } 22\end{array}$ & $\begin{array}{l}\text { N725440 } \\
\text { E3506520 }\end{array}$ & 4115 & $0 i 1$ & Electric & $8 / 6 / 71$ \\
\hline 30139 & Amoco & $\begin{array}{l}\text { Texas } \\
\text { Exploration } 23\end{array}$ & $\begin{array}{l}\text { N725220 } \\
\text { E3806857 }\end{array}$ & 3900 & $0 i 1$ & Electric & $9 / 29 / 71$ \\
\hline 30140 & Amoco & $\begin{array}{l}\text { Texas } \\
\text { Exploration } 24\end{array}$ & $\begin{array}{l}\text { N725481 } \\
\text { E3506872 }\end{array}$ & 4000 & $0 \nmid 1$ & Electric & $8 / 17 / 71$ \\
\hline 30250 & HNG & $\begin{array}{l}\text { Anderson } \\
\text { Guiterman } 1\end{array}$ & $\begin{array}{l}\text { N732200 } \\
\text { E3505680 }\end{array}$ & 7450 & $0 i 1$ & ISF/Sonic & $10 / 19 / 73$ \\
\hline 30272 & HING & $\begin{array}{l}\text { Anderson } \\
\text { Guiterman } 2\end{array}$ & $\begin{array}{l}\text { N731620 } \\
\text { E3506520 }\end{array}$ & 5912 & Abandoned & Electric & $1 / 13 / 74$ \\
\hline 31274 & Amoco & $\begin{array}{l}\text { Texas } \\
\text { Exploration } 25\end{array}$ & $\begin{array}{l}N 725465 \\
\text { E3509722 }\end{array}$ & 4107 & Abandoned & Electric & $1 / 27 / 79$ \\
\hline \multirow[t]{7}{*}{33325} & Praire & $\begin{array}{l}\text { McFadd in } 1 \\
\text { Trust }\end{array}$ & & 8654 & Abandoned & Electric & $10 / 26 / 78$ \\
\hline & $\begin{array}{l}\text { Jefferson } \\
\text { Lake Sulphur }\end{array}$ & $J L 1$ & $\begin{array}{l}\text { N729827 } \\
\text { E3509395 }\end{array}$ & 1161 & $\begin{array}{l}\text { Exploratory } \\
\text { Sulphur }\end{array}$ & Drillers & 1962 \\
\hline & $\begin{array}{l}\text { Jefferson } \\
\text { Lake Sulphur }\end{array}$ & $\mathrm{JL} 2$ & $\begin{array}{l}N 728758 \\
\text { E3511549 }\end{array}$ & 1504 & $\begin{array}{l}\text { Exploratory } \\
\text { Sulphur }\end{array}$ & & 1962 \\
\hline & $\begin{array}{l}\text { Jefferson } \\
\text { Lake Sulphur }\end{array}$ & $\mathrm{JL3}$ & $\begin{array}{l}\text { N724879 } \\
\text { E3509050 }\end{array}$ & 1744 & $\begin{array}{l}\text { Exploratory } \\
\text { Sulphur }\end{array}$ & Drillers & 1962 \\
\hline & $\begin{array}{l}\text { Jefferson } \\
\text { Lake Sulphur }\end{array}$ & $J L 4$ & $\begin{array}{l}\text { N728350 } \\
\text { E3511994 }\end{array}$ & 2384 & $\begin{array}{l}\text { Exploratory } \\
\text { Sulphur }\end{array}$ & Drillers & 1962 \\
\hline & $\begin{array}{l}\text { Jefferson } \\
\text { Lake Sulphur }\end{array}$ & JL5 & $\begin{array}{l}\text { N727188 } \\
\text { E3510671 }\end{array}$ & 1468 & $\begin{array}{l}\text { Exploratory } \\
\text { Sulphur }\end{array}$ & Drillers & 1962 \\
\hline & Stanolind & Pipkin A3 & $\begin{array}{l}\text { N726120 } \\
\text { E3512452 }\end{array}$ & 6742 & Abandoned & Electric & $5 / 14 / 36$ \\
\hline
\end{tabular}


Table B-1

(Cont)

\begin{tabular}{|c|c|c|c|c|c|c|c|}
\hline $\begin{array}{l}\text { API } \\
\text { No. }\end{array}$ & Operator & Well No. & Location & $\begin{array}{l}\text { Total Depth } \\
\text { (in feet) }\end{array}$ & Result & Logs & $\begin{array}{c}\text { Cate } \\
\text { Completed }\end{array}$ \\
\hline & Jayred & Fitzhugh 8 & $\begin{array}{l}\text { N723640 } \\
\text { E3505557 }\end{array}$ & & Abandoned & Electric & $5 / 22 / 62$ \\
\hline & Texaco & Pipkin 5 & $\begin{array}{l}\text { N729135 } \\
\text { E3512835 }\end{array}$ & 8616 & Abandoned & Electric & $2 / 3 / 53$ \\
\hline & Texaco & Pipkin 6 & $\begin{array}{l}\text { N725483 } \\
\text { E3512376 }\end{array}$ & 8806 & Abandoned & Electric & $4 / 5 / 53$ \\
\hline
\end{tabular}


Table B-2

Well Control

\begin{tabular}{|c|c|c|c|c|c|c|c|c|c|c|c|c|c|c|c|c|c|c|c|}
\hline $\begin{array}{l}\text { API } \\
\text { No. }\end{array}$ & Well No. & $\begin{array}{l}\text { Map } \\
\text { Symbol }\end{array}$ & $\begin{array}{l}\text { Top } \\
\text { Cap } \\
\end{array}$ & $\begin{array}{l}\text { Top } \\
\text { Salt } \\
\end{array}$ & $\begin{array}{l}\text { Base } \\
\text { Salt } \\
\end{array}$ & $L$ & PL & A & $B F$ & B & $A B$ & $c$ & RL & $D$ & SD & $E$ & $\mathrm{DR}$ & $M$ & $F$ \\
\hline 3730 & $\begin{array}{l}\text { Amoco (Pan Am) } \\
\text { TX Exploration } 1\end{array}$ & 1 & 1600 & 1820 & 2665 & 880 & 1110 & - & - & 2730 & 3140 & 3590 & 3980 & 4260 & 4960 & 5130 & - & - & \\
\hline 3257 & $\begin{array}{l}\text { Amoco (Pan Am) } \\
\text { TX Exploration } 2\end{array}$ & 2 & 1590 & 1935 & 2760 & & & & & & & 3000 & 3240 & 3825 & 4110 & 4765 & 5115 & 5802 & \\
\hline 3200 & $\begin{array}{l}\text { Amoco (Pan Am) } \\
\text { TX Exploration } 3\end{array}$ & 3 & 1300 & 1630 & 2890 & 765 & 852 & & & & & & & 3430 & 4160 & & & & \\
\hline 3265 & $\begin{array}{l}\text { Amoco (Pan Am) } \\
\text { TX Exploration } 4\end{array}$ & 4 & 1380 & 1970 & 2910 & 1095 & 1250 & & & & 3240 & 3500 & & & 4130 & 4490 & 4640 & & \\
\hline 3267 & $\begin{array}{l}\text { Amoco (Pan Am) } \\
\text { TX Exploration } 5\end{array}$ & 5 & 1300 & 1800 & 2935 & & & & & & & 3300 & 3435 & 3655 & 4105 & 4565 & & & \\
\hline 3281 & $\begin{array}{l}\text { Amoco (Pan Am) } \\
\text { TX Exploration } 6\end{array}$ & 6 & & 1815 & 3470 & 1008 & 1175 & & & & & & & & & & 3830 & 4330 & \\
\hline 3282 & $\begin{array}{l}\text { Amoco (Pan Am) } \\
\text { TX Exploration } 7\end{array}$ & 7 & 1315 & 1640 & 3010 & & & & & & & & & & & 3465 & 4335 & & \\
\hline 3272 & $\begin{array}{l}\text { Amoco (Pan Am) } \\
\text { TX Exploration } 8\end{array}$ & 8 & 1220 & 1850 & & & & & & & & & & & & & & & \\
\hline 3290 & $\begin{array}{l}\text { Amoco (Pan Am) } \\
\text { TX Exploration } 9\end{array}$ & 9 & & 2015 & 2660 & & & & & & & 3090 & 3603 & 4000 & 4399 & 4660 & & & \\
\hline 3297 & $\begin{array}{l}\text { Amoco (Pan Am) } \\
\text { TX Exploration } 10\end{array}$ & 10 & & 1710 & 2990 & & & & & & & & & 3195 & 3980 & 4277 & 4703 & 5290 & \\
\hline 3303 & $\begin{array}{l}\text { Amoco (Pan Am) } \\
\text { TX Exploration } 11\end{array}$ & 11 & 1255 & 1630 & 3520 & 960 & 1190 & & & & & & & & 3880 & 4255 & 4735 & & \\
\hline 3303 & $\begin{array}{l}\text { Amoco (Pan Am) } \\
\text { TX Exploration IIST }\end{array}$ & $11 \mathrm{ST}$ & & & 3550 & & & & & & & & & & 3815 & 4140 & & & \\
\hline 3318 & $\begin{array}{l}\text { Amoco (Pan Am) } \\
\text { TX Exploration } 13\end{array}$ & 13 & 1340 & $\begin{array}{l}1730 t \\
4120 t\end{array}$ & $\begin{array}{l}\text { to } 3710 \\
\text { to } 4345\end{array}$ & 1000 & & & & & & & & & & & & & \\
\hline 3318 & $\begin{array}{l}\text { Amoco (Pan Am) } \\
\text { TX Exploration 13ST }\end{array}$ & 13ST & & $3330 t$ & $\begin{array}{l}2850 \\
\text { to } 3580\end{array}$ & & & & & & & & 4080 & 4360 & & & & & \\
\hline 3309 & $\begin{array}{l}\text { Amoco (Pan Am) } \\
\text { TX Exploration } 14\end{array}$ & 14 & & & 2740 & & & & & & 2930 & 3110 & 3495 & 4040 & & & & & \\
\hline 3322 & $\begin{array}{l}\text { Amoco (Pan Am) } \\
\text { TX Exploration } 15\end{array}$ & 15 & & & 3195 & & & & & & & & & & & & 3790 & & \\
\hline 3328 & $\begin{array}{l}\text { Amoco (Pan Am) } \\
\text { TX Exploration } 16\end{array}$ & 16 & & 1880 & 2990 & & & & & & & & & & & 3380 & & & \\
\hline
\end{tabular}




\begin{tabular}{|c|c|c|c|c|c|c|c|c|c|c|c|c|c|c|c|c|c|c|c|}
\hline $\begin{array}{l}\text { API } \\
\text { No. } \\
\end{array}$ & Well No. & $\begin{array}{c}\text { Map } \\
\text { Symbol }\end{array}$ & $\begin{array}{l}\text { Top } \\
\text { Cap } \\
\end{array}$ & $\begin{array}{l}\text { Top } \\
\text { Salt }\end{array}$ & $\begin{array}{l}\text { Base } \\
\text { Salt } \\
\end{array}$ & $L$ & $\mathrm{PL}$ & A & $B F$ & B & $\underline{A B}$ & C & $\underline{\mathrm{RL}}$ & $D$ & SD & $E$ & $\mathrm{DR}$ & $M$ & $F$ \\
\hline 3340 & $\begin{array}{l}\text { Amoco (Pan Am) } \\
\text { TX Exploration } 17\end{array}$ & 17 & & $1280^{\circ}$ & 3180 & & & & & & 3480 & 3940 & 4320 & & & & & & \\
\hline 3338 & $\begin{array}{l}\text { Amoco (Pan Am) } \\
\text { TX Exploration } 18\end{array}$ & 18 & & 1720 & 3030 & & & & & & & & 3110 & 3360 & 3470 & 3710 & & & \\
\hline 3355 & $\begin{array}{l}\text { Amoco (Pan Am) } \\
\text { TX Exploration } 19\end{array}$ & 19 & & & 3340 & & & & & & & 3550 & 3950 & & & & & & \\
\hline 3355 & $\begin{array}{l}\text { Amoco (Pan Am) } \\
\text { TX Exploration 19ST }\end{array}$ & 19ST & & & 3260 & & & & & & & 3610 & 3960 & & & & & & \\
\hline 30031 & $\begin{array}{l}\text { Amoco (Pan Am) } \\
\text { TX Exploration } 20\end{array}$ & 20 & 1580 & 2670 & 2810 & 940 & 1195 & & & & 2990 & 3300 & 3800 & 3950 & 4265 & 4445 & & & \\
\hline 30031 & $\begin{array}{l}\text { Amoco (Pan Am) } \\
\text { TX Exploration 20ST }\end{array}$ & 20ST & & & & & & & & & 3200 & & 3740 & 3850 & 4100 & 4190 & 4755 & & \\
\hline 30032 & $\begin{array}{l}\text { Amoco (Pan Am) } \\
\text { TX Exploration } 21\end{array}$ & 21 & 1055 & 2060 & 3340 & 770 & 920 & & & & & & & 3660 & 3985 & 4090 & & & \\
\hline 3359 & $\begin{array}{l}\text { Amoco (Pan Am) } \\
\text { TX Exploration } 22\end{array}$ & 22 & & & 2775 & & & & & & & & 3405 & 3800 & & & & & \\
\hline 30139 & $\begin{array}{l}\text { Amoco (Pan Am) } \\
\text { TX Exploration } 23\end{array}$ & 23 & & & 2810 & & & & & & & & & 3380 & & & & & \\
\hline 30140 & $\begin{array}{l}\text { Amoco (Pan Am) } \\
\text { TX Exploration } 24\end{array}$ & 24 & & & 3030 & & & & & & & & & 3410 & & & & & \\
\hline 31272 & $\begin{array}{l}\text { Amoco (Pan Am) } \\
\text { TX Exploration } 25\end{array}$ & 25 & & 2620 & 3740 & & & & & & & & & & & & & & \\
\hline 31274 & $\begin{array}{l}\text { Amoco (Pan Am) } \\
\text { TX Exploration } 26\end{array}$ & $? 6$ & & & 3235 & & & & & & & & & & 3577 & 3880 & 4315 & 4898 & \\
\hline 2884 & $\begin{array}{l}\text { Amoco (Pan Am) } \\
\text { Fitzhugh } 1\end{array}$ & Z1 & & 2120 & 2505 & & & & & & & 3160 & 3755 & & & & & & \\
\hline 2885 & $\begin{array}{l}\text { Amoco (Pan Am) } \\
\text { Fitzhugh } 2\end{array}$ & Z2 & 1690 & 2165 & 2685 & 1045 & 1360 & & & & 3125 & 3270 & 3995 & 4115 & & & & & \\
\hline 2829 & $\begin{array}{l}\text { Amoco (Pan Am) } \\
\text { Fitzhugh } 5\end{array}$ & Z5 & & & & & & 2430 & 2795 & 2960 & 3715 & 4205 & & 5230 & 5780 & 5950 & 6140 & 6960 & \\
\hline 3346 & $\begin{array}{l}\text { Amoco (Pan Am) } \\
\text { Pipkin Crow } 1\end{array}$ & $P C$ & & & & 1020 & 1200 & 2260 & 2440 & 2590 & 3230 & 3335 & 3680 & 3710 & 3760 & 3880 & 4320 & & \\
\hline 3079 & $\begin{array}{l}\text { Goodale-Bertman } \\
\text { Pan Am } 1\end{array}$ & GI & & & & 1050 & 1310 & 2420 & 2625 & 3002 & 3510 & 4015 & 4397 & 4635 & 5250 & 5405 & 5650 & & \\
\hline 3093 & $\begin{array}{l}\text { Goodale-Bertman } \\
\text { Pan Am } 2\end{array}$ & G2 & & & & 1055 & 1295 & 2400 & 2735 & 3030 & 3330 & 3800 & 4350 & 4610 & 5005 & 5162 & 5400 & & \\
\hline
\end{tabular}


Table B-2 (Cont)

\begin{tabular}{|c|c|c|c|c|c|c|c|c|c|c|c|c|c|c|c|c|c|c|c|}
\hline $\begin{array}{l}\text { API } \\
\text { No. }\end{array}$ & Well No. & $\begin{array}{l}\text { Map } \\
\text { Symbol } \\
\end{array}$ & $\begin{array}{l}\text { Top } \\
\text { Cap } \\
\end{array}$ & $\begin{array}{l}\text { Top } \\
\text { Salt } \\
\end{array}$ & $\begin{array}{l}\text { Base } \\
\text { Salt } \\
\end{array}$ & $L$ & $\mathrm{PL}$ & A & $\mathrm{BF}$ & B & $A B$ & $C$ & $\mathrm{RL}$ & $D$ & $S D$ & $E$ & DR & $M$ & $\mathrm{~F}$ \\
\hline 3128 & $\begin{array}{l}\text { Goodale-Bertman } \\
\text { Pan Am } 3\end{array}$ & G3 & & & & 1055 & 1295 & & & & & & & & & & & & \\
\hline 3129 & $\begin{array}{l}\text { Goodale-Bertman } \\
\text { Pan Am } 4\end{array}$ & G4 & & & & 1080 & 1300 & 2235 & 2420 & 2960 & 3425 & 3703 & 4220 & 4710 & & & & & \\
\hline 3131 & $\begin{array}{l}\text { Goodale-Bertman } \\
\text { Pan Am } 5\end{array}$ & G5 & & & & 1050 & 1280 & 2380 & 2745 & 3080 & 3370 & 3640 & 3990 & 4350 & 4820 & 4990 & 5250 & & \\
\hline 3132 & $\begin{array}{l}\text { Goodale-Bertman } \\
\text { Pan Am } 6\end{array}$ & G6 & 1650 & & & 1050 & 1280 & & & & & & & & & & & & \\
\hline 3160 & $\begin{array}{l}\text { Goodale-Bertman } \\
\text { TX Exploration } 7\end{array}$ & G7 & 1280 & & & 1070 & 1230 & & & & & & & & & & & & \\
\hline 3779 & $\begin{array}{l}\text { Goodale-Bertman } \\
\text { TX Exploration } 8\end{array}$ & G8 & 1580 & 1650 & 2350 & 1100 & 1380 & & & 3080 & 3210 & 3450 & 3760 & 4170 & 4320 & 4870 & 4990 & & \\
\hline 3781 & $\begin{array}{l}\text { Goodale-Bertman } \\
\text { TX Exploration } 9\end{array}$ & $G 9$ & & & & 1075 & 1300 & 2330 & 2530 & 2980 & 3350 & 3750 & 4140 & 4390 & & & & & \\
\hline 3215 & $\begin{array}{l}\text { Goodale-Bertman } \\
\text { TX Exploration } 11\end{array}$ & GII & & 1587 & 3050 & 1053 & 1260 & & & & 3610 & 3950 & 4270 & 4385 & 4500 & 4640 & 4855 & & \\
\hline 3269 & $\begin{array}{l}\text { Goodale-Bertman } \\
\text { Fitzhugh } 2 B\end{array}$ & $2 \mathrm{~B}$ & & 1560 & 1790 & & & 2000 & 2260 & 2640 & 3530 & 3940 & 4180 & & & & & & \\
\hline 3238 & $\begin{array}{l}\text { Goodale-Bertman } \\
\text { TX Exploration } 13\end{array}$ & G13 & 780 & 1390 & & & & & & & & & & & & & & & \\
\hline 3284 & $\begin{array}{l}\text { Goodale-Bertman } \\
\text { TX Exploration } 14\end{array}$ & G14 & & & & & & & & & & & & & & & & & \\
\hline 3289 & $\begin{array}{l}\text { Goodale-Bertman } \\
\text { TX Exploration } 15\end{array}$ & G15 & 1810 & & & & & 2350 & 2500 & 2825 & 3180 & 3330 & 3865 & 4000 & & & & & \\
\hline 3295 & $\begin{array}{l}\text { Goodale-Bertman } \\
\text { TX Exploraton } 16\end{array}$ & G16 & 1810 & & & & & 2380 & 2690 & 2975 & 3280 & 3550 & 3780 & 4040 & 4730 & 4900 & & & \\
\hline 3299 & $\begin{array}{l}\text { Goodale-Bertman } \\
\text { TX Exploration } 17\end{array}$ & G17 & & & & & & 2290 & 2550 & 2788 & 3300 & 3788 & 3912 & 4350 & 4720 & 4790 & & & \\
\hline 3308 & $\begin{array}{l}\text { Goodale-Bertman } \\
\text { TX Exploration } 18\end{array}$ & G18 & & 2300 & 2820 & & & & & & 3090 & 3385 & 3640 & 3760 & 4370 & 4550 & 4870 & & \\
\hline 3379 & $\begin{array}{l}\text { Goodale-Bertman } \\
\text { TX Exploration } 19\end{array}$ & G19 & & 2190 & 3025 & & & & & & 3100 & 3745 & 4070 & 4100 & 4140 & 4430 & & & \\
\hline 3324 & $\begin{array}{l}\text { Goodale-Bertman } \\
\text { TX Exploration } 20\end{array}$ & G20 & 1530 & 2105 & 2670 & & & & & & 2900 & 3120 & & 3760 & 38.30 & 4200 & & & \\
\hline 3354 & $\begin{array}{l}\text { Goodale-Bertman } \\
\text { TX Exploration } 21\end{array}$ & G21 & 1360 & 1690 & 2790 & & & & & & & & 3430 & 3590 & 3725 & 4105 & & & \\
\hline
\end{tabular}




\begin{tabular}{|c|c|c|c|c|c|c|c|c|c|c|c|c|c|c|c|c|c|c|c|}
\hline $\begin{array}{l}\text { API } \\
\text { No. } \\
\end{array}$ & Well No. & $\begin{array}{c}\text { Map } \\
\text { Symbol } \\
\end{array}$ & $\begin{array}{l}\text { Top } \\
\text { Cap }\end{array}$ & $\begin{array}{l}\text { Top } \\
\text { Salt } \\
\end{array}$ & $\begin{array}{l}\text { Base } \\
\text { Salt }\end{array}$ & $L$ & PL & A & $\mathrm{BF}$ & B & $A B$ & C & $\underline{\mathrm{RL}}$ & D & SD & $E$ & $\mathrm{DR}$ & M & $\mathrm{F}$ \\
\hline 3359 & $\begin{array}{l}\text { Goodale-Bertman } \\
\text { TX Exploration } 22\end{array}$ & G22 & 1470 & 1820 & 3050 & & & & & & & & 3720 & & & & $\therefore$ & & \\
\hline 3216 & $\begin{array}{l}\text { Goodale-Bertman } \\
\text { Fitzhugh Al }\end{array}$ & A1 & 1630 & & & 1030 & 1265 & 2390 & 2625 & 2930 & 3610 & 3940 & 4330 & 4535 & 4720 & 4800 & 4980 & & \\
\hline 3236 & $\begin{array}{l}\text { Goodale-Bertman } \\
\text { Fitzhugh A2 }\end{array}$ & A2 & 1560 & & & 1030 & 1285 & 2465 & 2750 & 3400 & 3695 & 3865 & 4150 & 4220 & 4700 & 4990 & & & \\
\hline 3237 & $\begin{array}{l}\text { Goodale-Bertman } \\
\text { Fitzhugh A3 }\end{array}$ & A3 & & & & 1025 & 1275 & 2400 & 2665 & 2860 & 3505 & 3840 & 4350 & 4605 & 5065 & 5190 & 5965 & & \\
\hline 3239 & $\begin{array}{l}\text { Goodale-Bertman } \\
\text { Fitzhugh A4 }\end{array}$ & A4 & & & & 1040 & 1305 & 2455 & 2660 & 2970 & 3590 & 4270 & 4570 & 4610 & 4960 & 5185 & 5355 & & \\
\hline 3244 & $\begin{array}{l}\text { Goodale-Bertman } \\
\text { Fitzhugh A5 }\end{array}$ & A5 & & & & 1033 & 1275 & 2392 & 2610 & 2830 & 3440 & 4015 & 4570 & 4770 & 4910 & 5005 & & & \\
\hline 3225 & $\begin{array}{l}\text { Goodale-Bertman } \\
\text { Fitzhugh B1 }\end{array}$ & B1 & & & & 1088 & 1360 & 2320 & 2635 & 2990 & 3380 & 3720 & 4150 & 4590 & & & & & \\
\hline 3274 & $\begin{array}{l}\text { Goodale-Bertman } \\
\text { Fitzhugin B2 }\end{array}$ & B2 & 2745 & & & & & & & 2530 & 3100 & 3520 & 4080 & 4305 & 4495 & 4600 & 5145 & & \\
\hline 2790 & $\begin{array}{l}\text { Adams \& Haggarty } \\
\text { Amoco (Pan Am)l }\end{array}$ & AHI & & 3080 & 3550 & & & & & & & & 3600 & 4100 & 4555 & 4820 & 5390 & & \\
\hline 2803 & $\begin{array}{l}\text { Adams \& Haggarty } \\
\text { Fitzhugh } 10\end{array}$ & AHIO & & & & 1047 & 1230 & 2390 & 2635 & 2850 & 3580 & 3870 & 4270 & 4630 & 5120 & 5265 & 5750 & & \\
\hline $280 b$ & $\begin{array}{l}\text { Adams \& Haggarty } \\
\text { Fitzhugh } 12\end{array}$ & AHI2 & & & & 1045 & 1240 & 2335 & 2575 & 2730 & 3860 & 3825 & 4110 & 4510 & 4970 & 5750 & 5665 & & \\
\hline 2787 & $\begin{array}{l}\text { Adams \& Haggarty } \\
\text { Marrs McLean } 11\end{array}$ & $M 11$ & & & & 990 & 1190 & 2300 & 2420 & 2760 & 3375 & 3550 & 3975 & 4085 & 4695 & 5020 & 5565 & & \\
\hline 2790 & $\begin{array}{l}\text { Adams \& Haggarty } \\
\text { Marrs McLean } 15\end{array}$ & M15 & & & & & & 2410 & 2660 & 2865 & 3820 & 4150 & 4360 & 4770 & 5090 & 5395 & 5705 & 6575 & \\
\hline 2792 & $\begin{array}{l}\text { Adams \& Haggarty } \\
\text { Marrs McLean } 17\end{array}$ & 1417 & & & & 997 & 1220 & 2325 & 2580 & 2740 & 3520 & 3705 & 4170 & 4315 & 4853 & 5060 & 5470 & 6270 & \\
\hline 2789 & $\begin{array}{l}\text { Adams \& Haggarty } \\
\text { Marrs McLean } 18\end{array}$ & M18 & & & & 1001 & 1203 & & & & & & & & & & & & \\
\hline 2020 & $\begin{array}{l}\text { Adams \& Haggarty } \\
\text { Crow 1 }\end{array}$ & $A H$ & & & & 970 & 1470 & 2395 & 2785 & 2980 & 3850 & 4140 & 4700 & 5070 & 5570 & 5705 & 6150 & & \\
\hline 3072 & Sunset Anderson 1 & Sl & & & & 970 & 1055 & & & & & & & & & & & & \\
\hline 3072 & Sunset Anderson 2 & \$2 & & 7630 & & 1040 & 1250 & 2350 & 2695 & 3070 & 3630 & 3810 & 4350 & 4570 & 4880 & 5040 & 5735 & 6440 & \\
\hline 30250 & $\begin{array}{l}\text { HNG Anderson } \\
\text { Guiterman } 1\end{array}$ & AGI & & & & & & 2470 & 2870 & 3075 & 3955 & 4260 & 4770 & 4950 & 5235 & 5560 & 6110 & 6890 & 8350 \\
\hline 30272 & $\begin{array}{l}\text { HING Anderson } \\
\text { Guiterman } 2\end{array}$ & AG2 & & & & & & & & & & & & & 5260 & 4550 & 6140 & 6920 & \\
\hline
\end{tabular}


Table B-2 (Cont)

\begin{tabular}{|c|c|c|c|c|c|c|c|c|c|c|c|c|c|c|c|c|c|c|c|}
\hline $\begin{array}{l}\text { API } \\
\text { ilo. }\end{array}$ & Well No. & $\begin{array}{l}\text { Map } \\
\text { Symbol }\end{array}$ & $\begin{array}{l}\text { Top } \\
\text { Cap }\end{array}$ & $\begin{array}{l}\text { Top } \\
\text { Salt }\end{array}$ & $\begin{array}{l}\text { Base } \\
\text { Salt }\end{array}$ & $L$ & $P L$ & A & $B F$ & $B$ & $A B$ & C & $\mathrm{RL}$ & D & $S D$ & E & DR & $M$ & $\underline{F}$ \\
\hline 2776 & $\begin{array}{l}\text { McCarty (HNG) } \\
\text { Davidson E] }\end{array}$ & E1 & & & & & & 2400 & 2905 & 3200 & 3820 & 4205 & 4505 & 4740 & 5045 & 5240 & 5900 & 6620 & \\
\hline 3091 & HiNG Davidson E2 & E2 & & & & 975 & 1200 & 2335 & 2590 & 3195 & 3730 & 3930 & 4260 & 4500 & 4870 & 5230 & 5740 & & \\
\hline 3376 & HNG Davidson E3 & E3 & & & & & 1220 & 2350 & 2630 & 3200 & 3925 & 4165 & 4710 & 4890 & 5335 & 5570 & 6125 & & \\
\hline 3121 & Gulf Anderson 1 & Gulf & & & & & 1400 & 2250 & 2350 & 2920 & 3390 & 3845 & 4150 & 4265 & 4590 & 4715 & 5300 & & \\
\hline 2772 & Pace & PA & & & & & & 2350 & 2455 & 2810 & 3770 & 4180 & 4690 & 5030 & 5550 & 5650 & 6215 & 6930 & \\
\hline 2021 & Goldrus & GO & & & & 970 & 1450 & 2380 & 2600 & 2950 & 3710 & 4715 & 4440 & 4760 & 4980 & 5100 & 5795 & & \\
\hline 2023 & $6 \mathrm{TH} 1$ & $6-1$ & & & & 960 & 1450 & 2295 & 2590 & 2930 & 3760 & 4205 & 4595 & 4670 & 5165 & 5250 & 5860 & & \\
\hline 2022 & $6 \mathrm{TH} 2$ & $6-2$ & & & & 990 & 1400 & 2210 & 2465 & 2880 & 3935 & 4230 & 4625 & 4750 & 5145 & 5495 & 6160 & & \\
\hline 2887 & $\begin{array}{l}\text { Bering (Wayne) } \\
\text { Fitzhugh } 1 \mathrm{~A}\end{array}$ & W1 & & & & & & 2355 & 2650 & 2810 & 3250 & 3660 & 4100 & 4265 & 4515 & 4635 & 4270 & & \\
\hline 2775 & $\begin{array}{l}\text { Stanolind } \\
\text { Davidson } 1\end{array}$ & DT & 10,113 & & & & & & & & & & & & & & & & \\
\hline $2885^{\circ}$ & $\begin{array}{l}\text { Stanolind } \\
\text { Fitzhugh }\end{array}$ & W2 & & & & & & 2470 & 2710 & 2950 & 3260 & 3820 & 4010 & 4740 & 4360 & 4510 & & & \\
\hline \multirow[t]{2}{*}{2907} & $\begin{array}{l}\text { Stanolind } \\
\text { McFadd in } 3 \mathrm{~A}\end{array}$ & W3 & & & & & & 2400 & 2665 & 2900 & 3210 & 3550 & $4005^{\prime}$ & 4280 & 4490 & 4795 & & & \\
\hline & $\begin{array}{l}\text { Stanolind } \\
\text { Pipkin } 3 A\end{array}$ & $3 A$ & & & & & & 2305 & 2650 & 2825 & 3210 & 3540 & 3970 & 4400 & 4945 & 5340 & 6065 & & \\
\hline 2907 & $\begin{array}{l}\text { Stanolind } \\
\text { McFaddin } 3 S T\end{array}$ & W3A & & & & & & & & & 3210 & 3510 & 3900 & 4095 & 4370 & 4515 & 4750 & & \\
\hline \multirow[t]{2}{*}{2890} & $\begin{array}{l}\text { Bering (Wynne) } \\
\text { Fitzhugh } 4\end{array}$ & W4 & 1930 & $\begin{array}{l}2140 \\
2815\end{array}$ & $\begin{array}{l}\text { to } 2280 \\
\text { to } 2940\end{array}$ & & & & & & & 3215 & 3610 & 3980 & 4050 & 4290 & 4780 & & \\
\hline & $\begin{array}{l}\text { Jayred } \\
\text { Fitzhugh } 8\end{array}$ & J8 & & & & & & 2550 & 2905 & 3450 & 4180 & 4430 & 5290 & 5575 & 6090 & 6230 & 6450 & & \\
\hline 2835 & $\begin{array}{l}\text { Jayred } \\
\text { Fitzhugh } 9\end{array}$ & J9 & & & & 1075 & 1250 & 2578 & 2915 & 3380 & 4000 & 4520 & 5030 & 5370 & 5835 & 5975 & 6190 & & \\
\hline 3094 & $\begin{array}{l}\text { Jayred } \\
\text { Fitzhugh } 10\end{array}$ & J10 & & & & 1082 & 1290 & 2400 & 2730 & 3150 & 3490 & 3950 & 4560 & 4960 & 5450 & 5630 & & & \\
\hline 3133 & $\begin{array}{l}\text { Jayred } \\
\text { Fitzhugh } 11\end{array}$ & וונJ & & & & 1050 & 1320 & 2455 & 2845 & 3000 & 3490 & 3970 & 4510 & 4740 & 5095 & 5250 & 5430 & & \\
\hline 33325 & $\begin{array}{l}\text { Prairie } \\
\text { McFaddin } 1\end{array}$ & Prairie 1 & & & , & & & 2310 & 2685 & 3140 & 3490 & 3805 & 4675 & 4785 & 5410 & 5890 & 6275 & 7785 & \\
\hline 2024 & Texaco Crow 1 & $\mathrm{Cl}$ & & & & & & 1860 & 1970 & 2465 & 3070 & 3190 & 3540 & 3750 & 4005 & 4165 & & & \\
\hline 2025 & Texaco Crow 2 & $\mathrm{C2}$ & & 5190 & & 1010 & 1270 & 2010 & 2100 & 2525 & 3115 & 3220 & 3360 & 3635 & 3960 & 4085 & 4895 & & \\
\hline 2892 & Texaco Fitzhugh 2 & TXF2 & & & & & & & & & & & & & & & & & \\
\hline
\end{tabular}




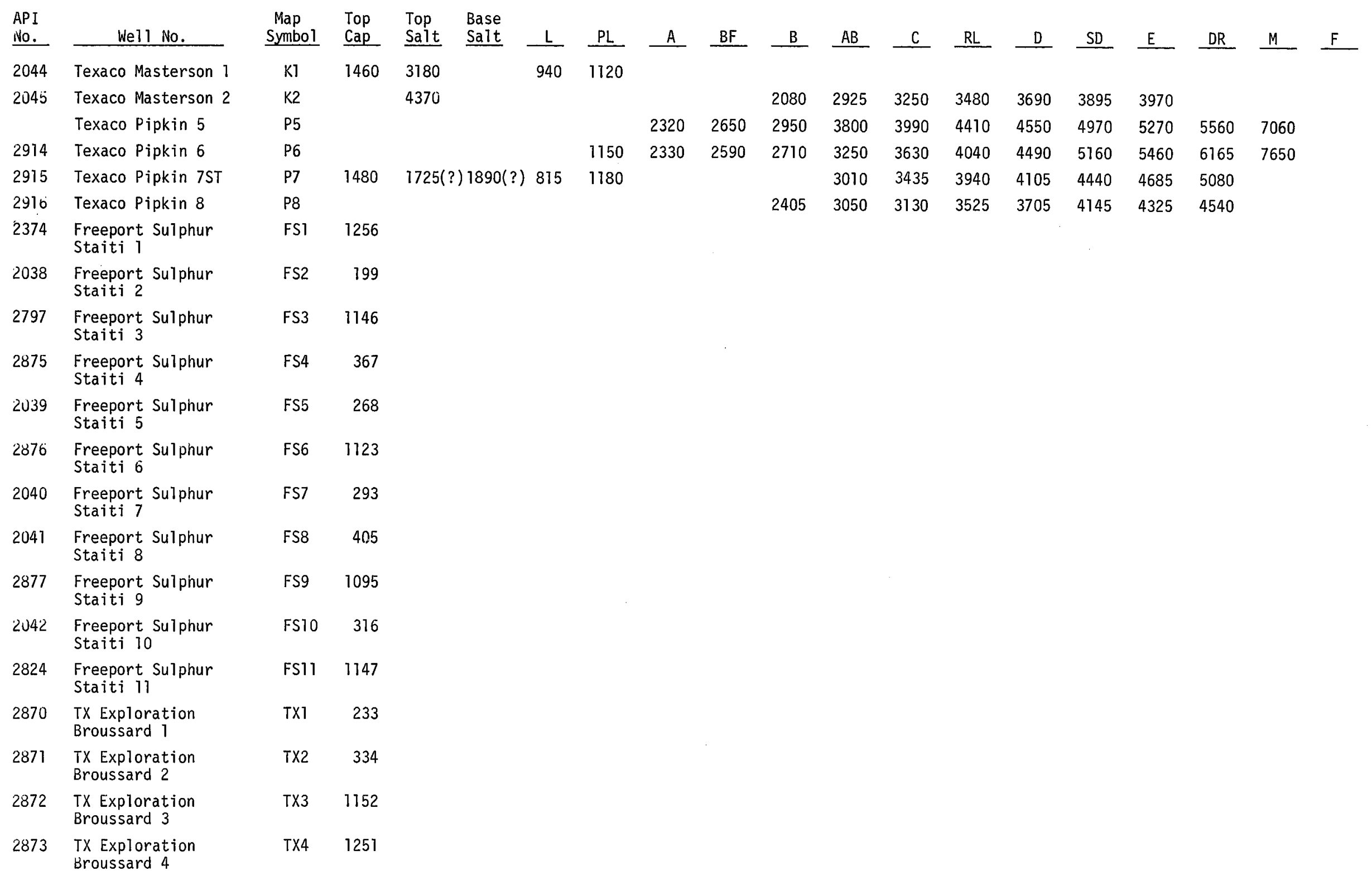


Table B-2 (Cont)

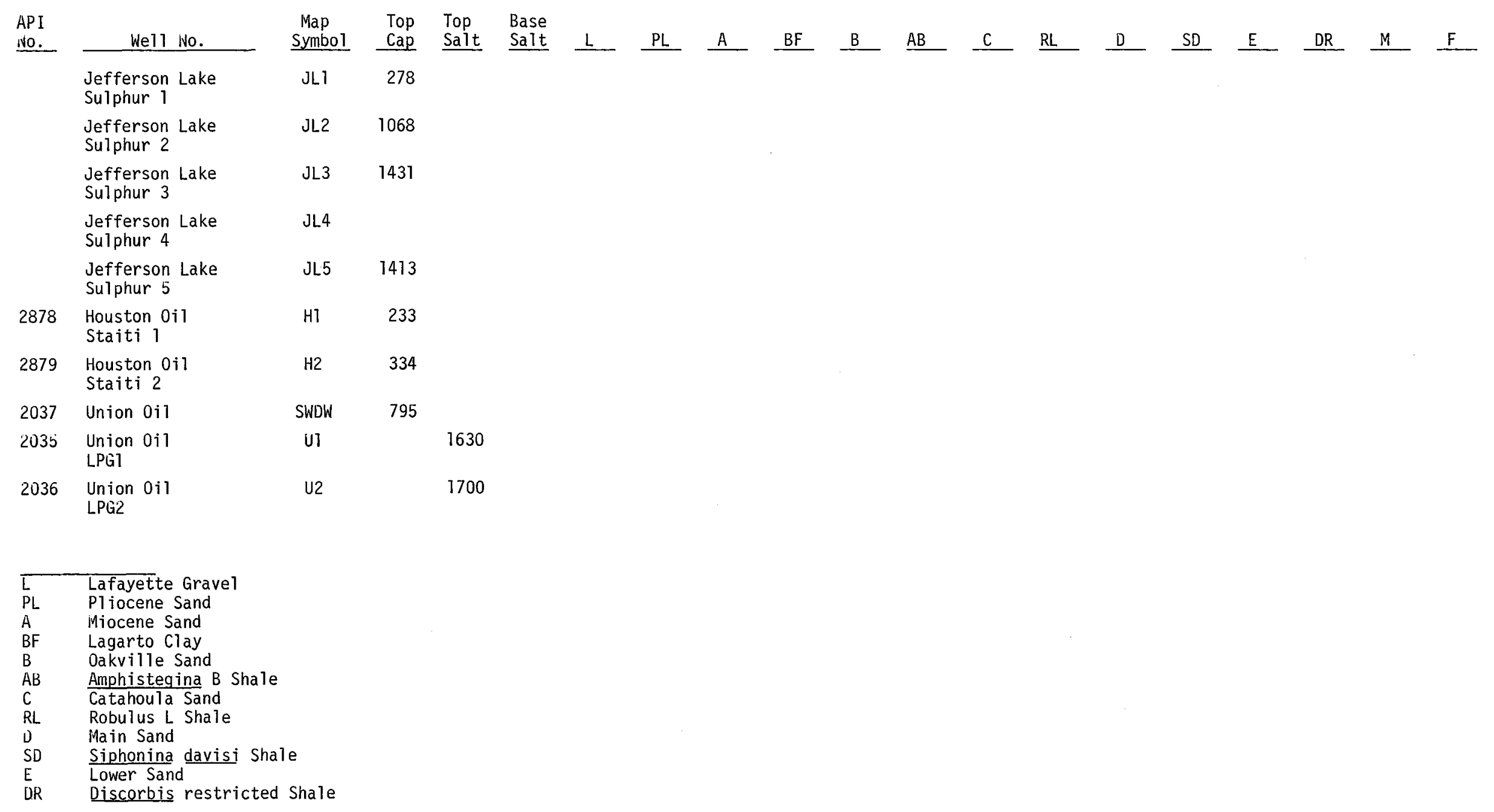




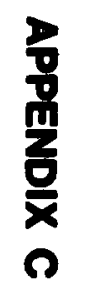


APPENDIX C

List of Contacts

$C-1 / C-2$ 
APPENDIX C

List of Contacts

\begin{tabular}{|c|c|c|}
\hline United Aerial Mapping & San Antonio & Ben Meitzen \\
\hline $\mathrm{PB} / \mathrm{KBB}$, Inc. & Houston & $\begin{array}{l}\text { Thayne Depuey } \\
\text { Joe Cella } \\
\text { Gene Ford } \\
\text { Mark Stiener }\end{array}$ \\
\hline Amoco Production Co. & Houston & $\begin{array}{l}\text { Ted Wenzeler } \\
\text { Tom Pinkstaff }\end{array}$ \\
\hline DOE SPR-PO & Washington, DC & Dick Smith \\
\hline DOE SPR-PMO & New Orleans & $\begin{array}{l}\text { Ed Chapple } \\
\text { Bob Mazurkiewicz } \\
\text { Bob Mosely } \\
\text { Larry Rousseau } \\
\text { Leon Stepp } \\
\text { Joyce Terrling } \\
\text { Don Whittington }\end{array}$ \\
\hline $\begin{array}{l}\text { Texas Railroad } \\
\text { Commission }\end{array}$ & Houston & $\begin{array}{l}\text { Elva Fleckenstine } \\
\text { Paul Stagg } \\
\text { W. L. Gabelmann, Jr. }\end{array}$ \\
\hline $\begin{array}{l}\text { Texas Railroad } \\
\text { Commission }\end{array}$ & Austin & Bob Harris \\
\hline $\begin{array}{l}\text { Texas Dept of Water } \\
\text { Resources }\end{array}$ & Orange & David Buchannan \\
\hline $\begin{array}{l}\text { Texas Dept of Water } \\
\text { Resources }\end{array}$ & Austin & $\begin{array}{l}\text { Bob Bluntzer } \\
\text { N. A. Jeier } \\
\text { Mike Howard }\end{array}$ \\
\hline $\begin{array}{l}\text { Texas Bur. Economic } \\
\text { Geology }\end{array}$ & Austin & $\begin{array}{l}\text { Lee Jirik } \\
\text { Jerry Wermund } \\
\text { Frank Brown }\end{array}$ \\
\hline $\begin{array}{l}\text { Sabine Pass Terminal } \\
\text { (Internorth, Inc.) }\end{array}$ & Houston & $\begin{array}{l}\text { John Chauche } \\
\text { Jerry Duffey }\end{array}$ \\
\hline Union $0 i 1$ Co & Beaumont & Ron Thompson \\
\hline
\end{tabular}




\section{DISTRIBUTION :}

US Department of Energy Strategic Petroleum Reserve Program Office 1000 Independence Ave., SW Washington, DC 20585

Attn: H. Jones

L. Pettis

R. Smith

US Department of Energy (13)

Strategic Petroleum Reserve Project Management Office 900 Commerce Rd East New Orleans, LA 70123

Attn: C. C. Johnson

G. A. Stafford

C. L. Steinkamp

E. E. Chapple (7)

J. Guarisco (2)

E. A. Crabtree

Aerospace Corp

880 Commerce Rd West, Suite 300

New Orleans, LA 70123

Attn: K. Henrie

Aerospace Corp

P. 0. Box 92957

Los Angeles, CA 90009

Attn: G. F. Kuncir

Jacobs/D'Appolonia Engineers

6226 Jefferson Hwy, Suite B

New Orleans, LA 70123

Attn: H. Kubicek

P. Campbe11

Amoco Production Co.

P.0. Box 3092

Houston, TX 77001

Attn: T. J. Winzeler

Sabine Pass Terminal

P.U. Box 4420

Houston, TX 77210

Attn: J. G. Chauche
$\mathrm{PB} / \mathrm{KBB}$, Inc

11999 Katy Freeway \#600

Houston, TX 77079

Attn: V. Lepardo

T. R. Magorian

133 South Drive

Amherst, NY 14226

Union 0 i1 Co.

P.0. Box 237

Nederland, TX 77627

Attn: R. Thompson

4000 A. Narath

4500 E. H. Beckner

4540 M. L. Kramm

4543 J. F. Ney

4543 R. J. Hart

4543 T. S. Ortiz

4543 File (10)

8214 M. A. Pound

3141 L. J. Erickson (5)

3151 W. L. Garner (3) For DOE/TIC (Unlimited Release)

\section{DOE/TIC (25)}

(C. Dal in, 3154-3) 